Molnár Endre Mihály

\title{
AZ ÁLLAMI KOCKÁZATI TŐKEBEFEKTETŐK SZEREPE A STARTUP ÖKOSZISZTÉMÁBAN ÉS BEFEKTETÉSI PREFERENCIÁIK
}

Vállalkozások Pénzügyei Tanszék

Témavezető: Jáki Erika, PhD

(C) Minden jog fenntartva - Molnár Endre Mihály, 2021 
Budapesti Corvinus Egyetem

Gazdálkodástani Doktori Iskola

\section{AZ ÁLLAMI KOCKÁZATI TŐKEBEFEKTETŐK SZEREPE A STARTUP ÖKOSZISZTÉMÁBAN ÉS BEFEKTETÉSI PREFERENCIÁIK}

Doktori értekezés

Endre Mihály Molnár

Budapest, 2021 


\section{Tartalomjegyzék}

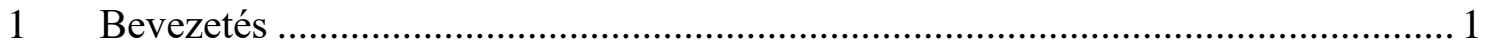

2 A startup-ökoszisztéma fogalmi keretrendszere ………………………………..... 4

2.1 A startup-ökoszisztéma definíciója................................................................ 4

2.2 A startup ökoszisztéma tagjai .................................................................

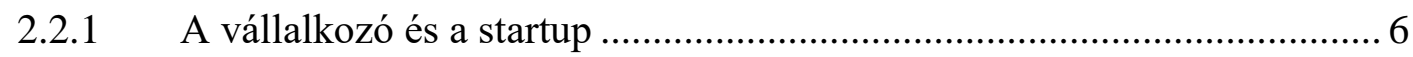

2.2.2 Inkubátorok és akcelerátorok .......................................................... 8

2.2.3 Angyalbefektetők ............................................................................. 10

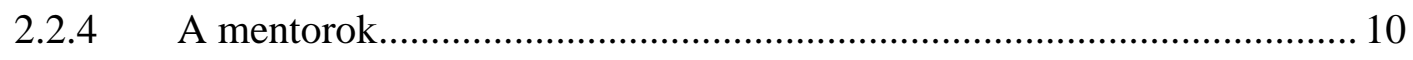

2.2.5 A közösségi finanszírozás ....................................................................... 11

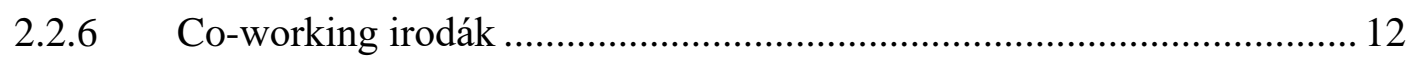

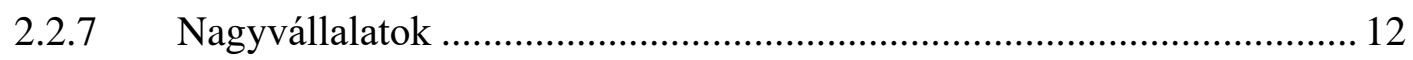

2.2.8 Kockázati tőkealap-kezelö társaságok ……………………………….... 13

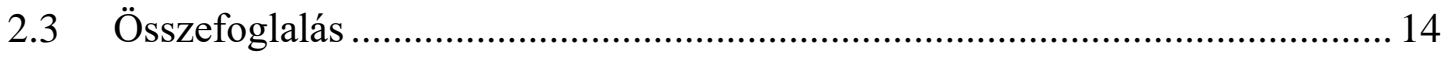

3 A magyar startupperek és a startup ökoszisztéma jellemzői ................................... 16

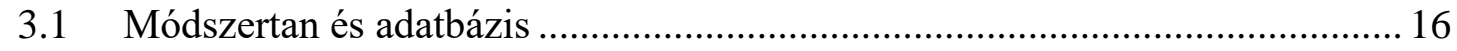

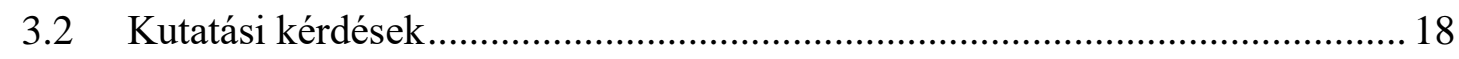

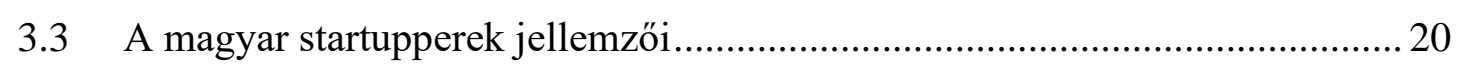

3.3.1 A startupok létrehozásának motivációi .................................................... 23

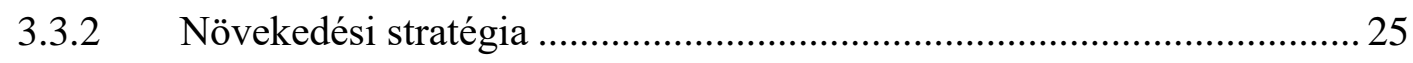

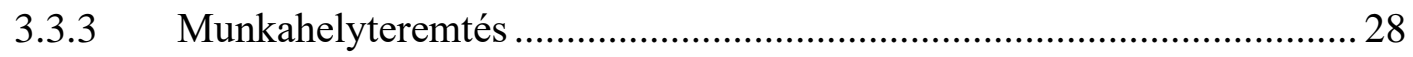

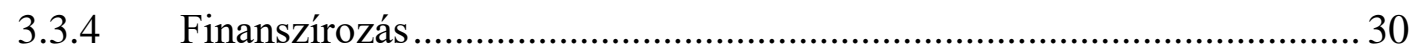

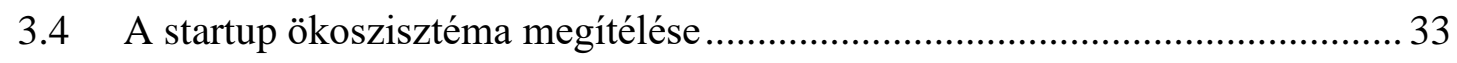

3.4.1 A startup ökoszisztéma jellemzöinek fontossága ……………………….... 34

3.4.2 A startup ökoszisztéma jellemzőinek megítélése...................................... 36

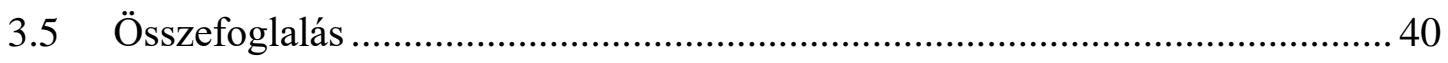

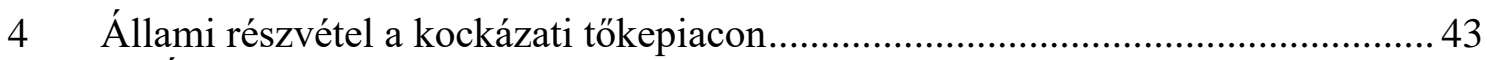

4.1 Állami beavatkozás piaci kudarcok következményeként ................................... 44

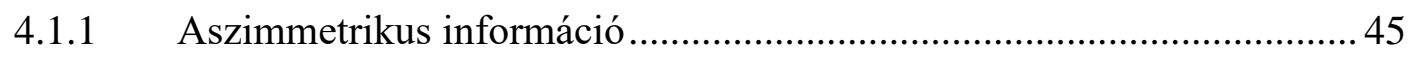

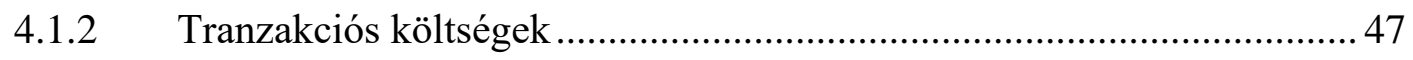

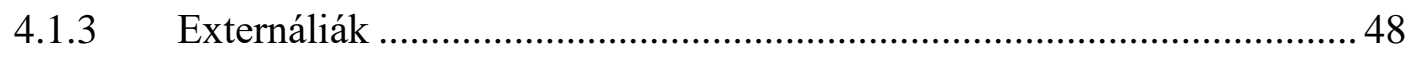

4.2 A kvalitatív szisztematikus szakirodalmi összefoglaló kutatási módszertana.. 49

4.2.1 Adatgyüjtési módszertan ...................................................................... 49

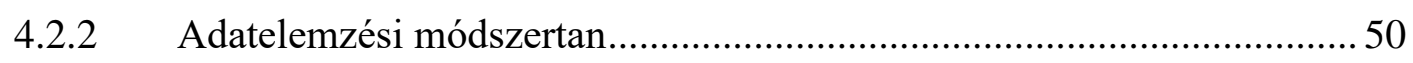

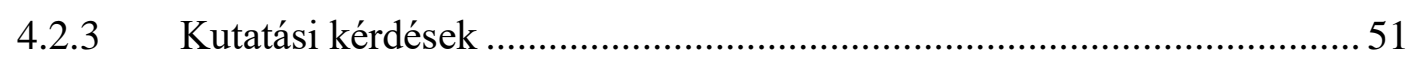

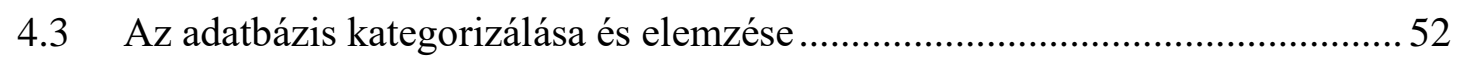

4.3.1 A kutatási terület folyóiratai..................................................................52 
4.3.2 A cikkek által felhasznált adatbázisok és módszertanok ...................... 54

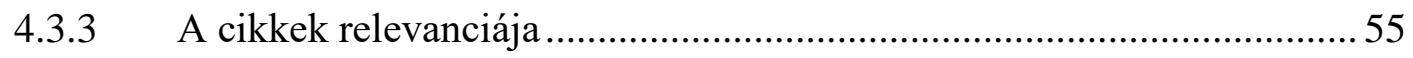

4.3.4 A szerző származása a vizsgált földrajzi területhez képest....................57

4.4 A kutatási kérdések kapcsolata a vizsgált földrajzi területtel és időszakkal .... 59

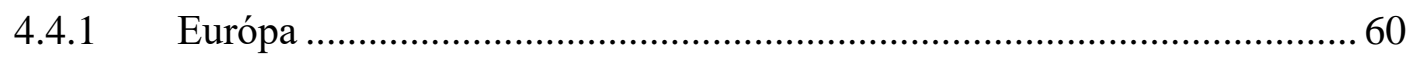

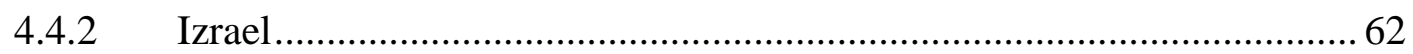

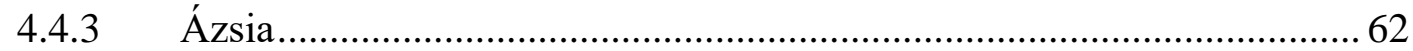

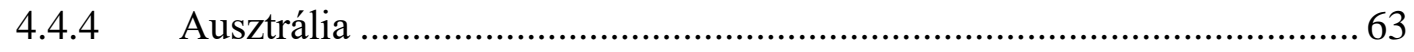

4.4.5 Kanada, Amerikai Egyesült Államok, Globális szint ............................ 63

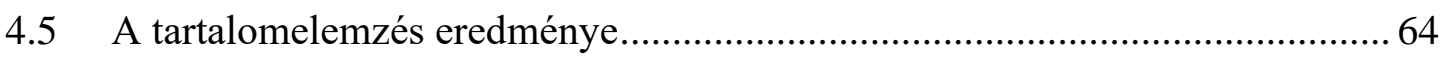

4.5.1 Tisztán állami kockázati tőke (közvetlen beavatkozás) .......................... 64

4.5.2 Az állami kockázati tőke és a magán kockázati tőke partnersége............ 68

4.5.3 Az állami kockázati tőke beavatkozásaz inkubációs fázisú

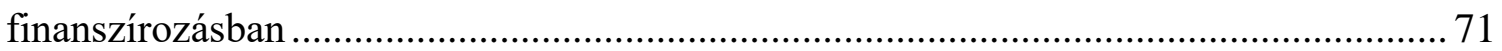

4.5.4 Összegzése a szakirodalomban tett javaslatokról.................................. 74

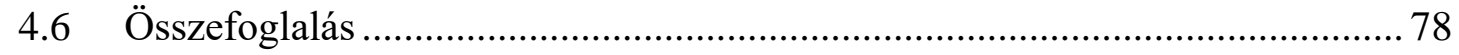

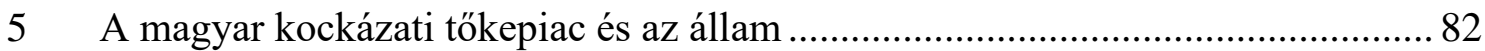

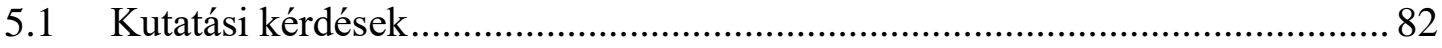

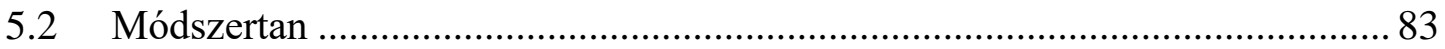

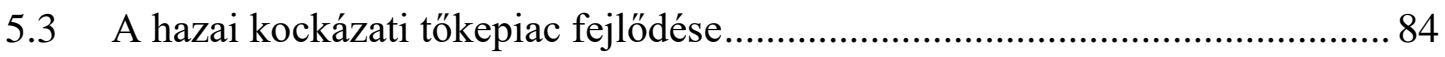

5.4 Közvetett állami beavatkozás - a JEREMIE program .................................. 87

5.4.1 A Jeremie program története és folytatása Magyarországon ..................8 87

5.4.2 A magyarországi Jeremie program értékelése .................................... 91

5.4.3 A Jeremie program összehasonlítása nemzetközi tapasztalatokkal ........99

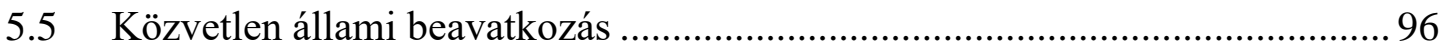

5.5.1 MFB Invest által tulajdonolt alapok és tőkealap-kezelök .......................97

5.5.2 Hiventures Kockázati Tőkealap-kezelő Zrt. (jogelődje: CKTA) ............ 99

5.5.3 Széchenyi Tőkealap-kezelő Zrt...................................................... 101

5.5.4 Állami és privát kockázati tőkebefektetők jellemzőinek eltérése .......... 103

5.5.5 A mentőprogramok jelene és jövője .................................................. 104

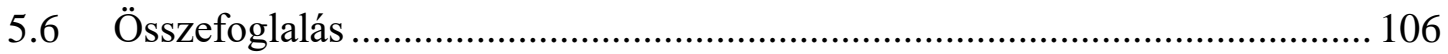

6 Az állami tulajdonú kockázati tőkebefektetők befektetési preferenciái ............... 109

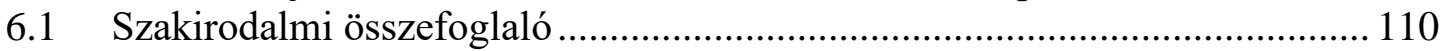

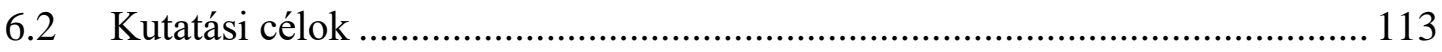

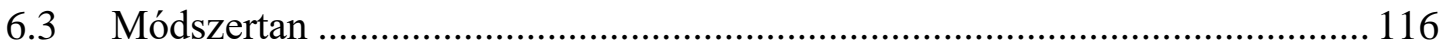

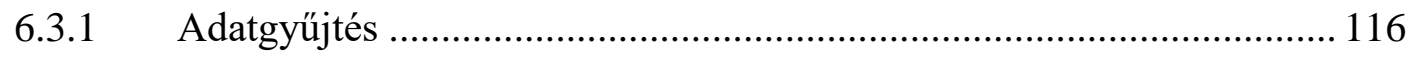

6.3.2 Adatelemzési eljárás................................................................ 118

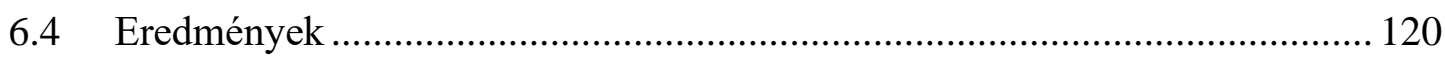




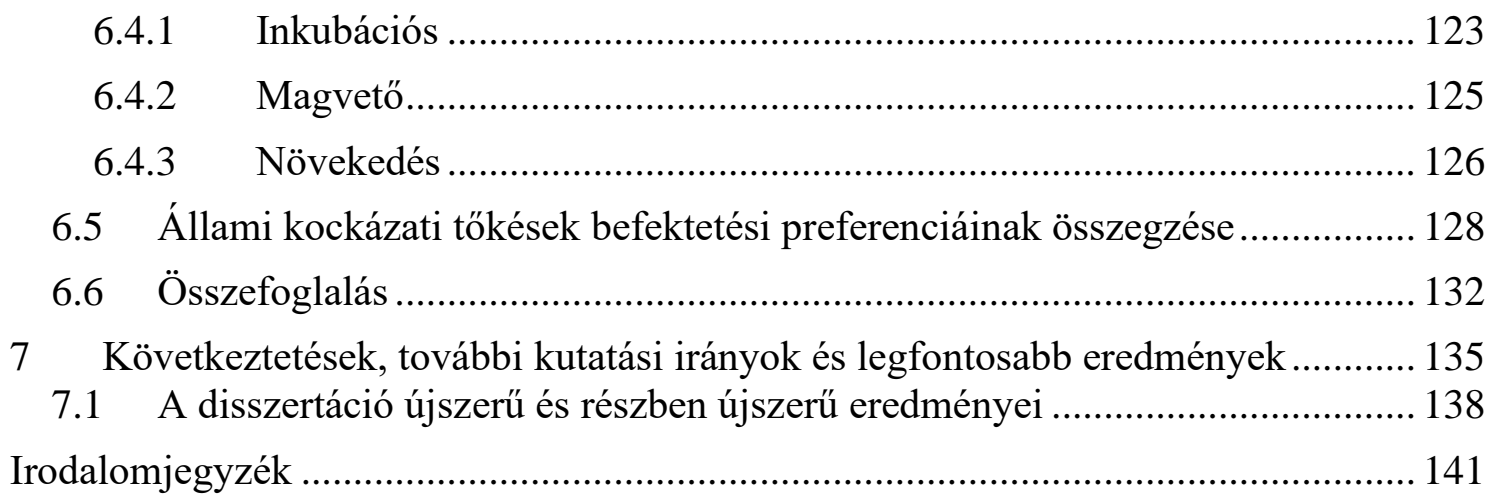




\section{Ábrajegyzék}

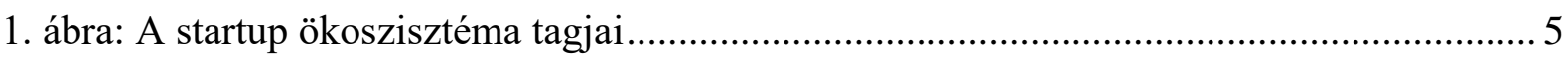

2. ábra: A startup-cégek finanszírozási fázisai .................................................................... 8

3. ábra: A magyar startup-ökoszisztéma startuppereinek legmagasabb képzettsége ................ 21

4. ábra: A startupperek képesítésének területei …………………………………………...... 22

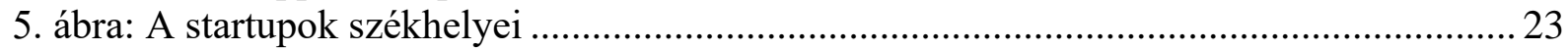

6. ábra: Tevékenységek, amelyekhez a startupperek segítséget igényelnek ………………..... 27

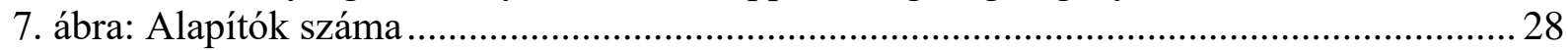

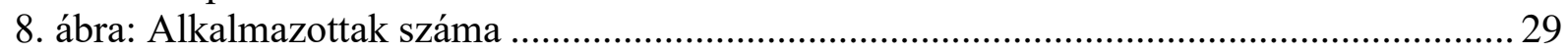

9. ábra: Mikor terveznek a startupok új munkavállalókat felvenni? ......................................... 29

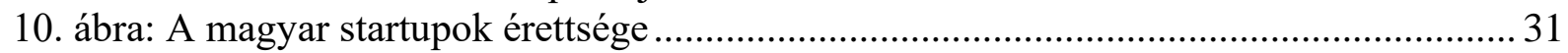

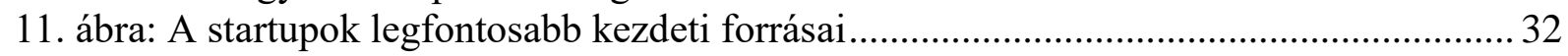

12. ábra: Hova fordulnak a startupperek új pénzügyi forrásokért? ........................................... 33

13. ábra: Azonosított kutatási tendenciák az évek során........................................................57

14. ábra: A cikkek megoszlása vizsgált területük szerint.......................................................59

15. ábra: A magyarországi kockázati tőkebefektetési volumen 2007 és 2018 között az életciklus különböző szakaszaiban, ezer euróban .................................................................. 86

16. ábra: A befektetési preferenciák hierarchiája összesítve a verbális protokoll elemzés

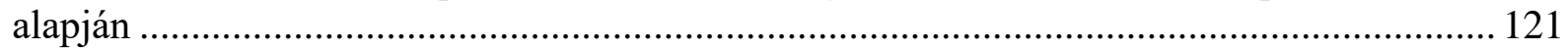

17. ábra: Az innovációhoz kötődő megfigyelések aránya a termék/szolgáltatás kategóriában a verbális protokoll elemzés alapján ..................................................................................... 122 18. ábra: A befektetési preferenciák hierarchiája az inkubációs szakaszban és összesítve a verbális protokoll elemzés alapján .................................................................................... 123 19. ábra: A befektetési preferenciák hierarchiája magvető szakaszban és összesítve a verbális protokoll elemzés alapján. 125 20. ábra: A befektetési preferenciák hierarchiája növekedési szakaszban és összesítve a verbális protokoll elemzés alapján 127 


\section{Táblázatok jegyzéke}

1. Táblázat: Kutatási kérdések a 3. fejezethez ............................................................... 19

2. táblázat: Propozíciók a 3. fejezethez ………………………………………………..... 19

3. táblázat: A startupok indításának motivációi - nők esetén .................................................. 24

4. táblázat: A startupok indításának motivációi - férfiak esetén.................................................24

5. táblázat: A startup ökoszisztéma jellemzőinek fontossága ………………………………....... 34

6. táblázat: Az alminták átlagának összehasonlítása (ANOVA és Hochberg $\alpha<5 \%$ ).............. 36

7. táblázat: A startup ökoszisztéma jellemzőinek minőségi megítélése...................................... 36

8. Táblázat: A 3. fejezet eredményeinek táblázata .................................................................... 41

9. táblázat: Kutatási kérdések a 4. fejezethez...................................................................... 51

10. táblázat: Propozíciók a 4. fejezethez …………………………………………….......52

11. táblázat: A kutatási terület Scimago általi besorolás szerinti felosztása ..............................53

12. táblázat: Alkalmazott módszertan a cikkekben ...................................................................5 55

13. táblázat: Vizsgált földrajzi terület és időszak ………………………………………......59

14. táblázat: A tisztán állami kockázati tőke pozitív megnyilvánulásai ..................................... 64

15. táblázat: A tisztán állami kockázati tőke negatív megnyilvánulásai.................................... 67

16. táblázat: Az állami és magán partnerségủ kockázati tőke pozitív megnyilvánulásai ........ 69

17. táblázat: Az állami és magán partnerségü kockázati tőke negatív megnyilvánulásai......... 70

18. táblázat: Az inkubációs fázisban történő állami kockázati tőkés beavatkozás pozitív megnyilvánulásai .................................................................................................... 72

19. táblázat: Az inkubációs fázisban történő állami kockázati tőkés beavatkozás negatív

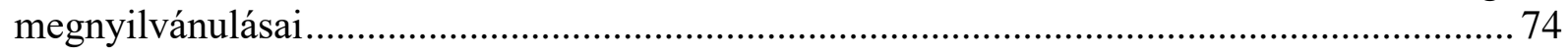

20. táblázat: Ajánlások az állami beavatkozáshoz …………………………………………. 74

21. táblázat: A 4. fejezet eredményeinek táblázata ……………………………………….... 78

22. táblázat: Az azonosított pozitív és negatív megnyilvánulások összehasonlítása ................ 80

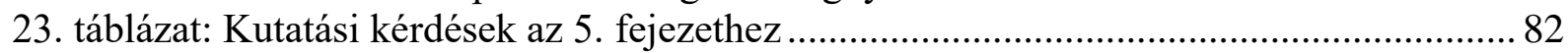

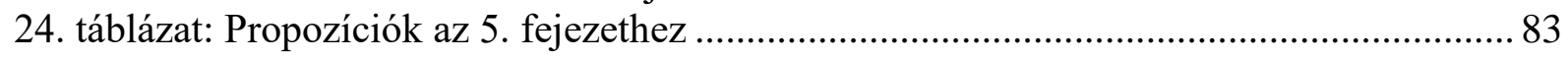

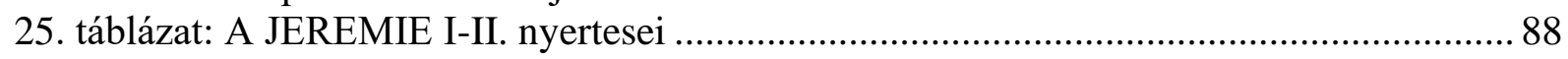

26. táblázat. Az összes befektetés száma és a Jeremie Alapok részaránya ................................ 92

27. táblázat: Az MFB Invest Befektetési és Vagyonkezelő Zrt. .............................................. 97

28. táblázat: A Széchenyi Tőkealap-kezelő Zrt. ................................................................. 101

29. táblázat: A Széchenyi Tőkealap-kezelő Zrt. befektetési tevékenysége............................. 102

30. táblázat: Állami tőkés mentőcsomagok Magyarországon................................................. 105

31. táblázat: Az 5. fejezet eredményeinek táblázata ……………………………………..... 107

32. táblázat: Kutatási kérdések a 6. fejezethez.................................................................... 113

33. táblázat: A verbális protokoll elemzés végrehajtásának kritériumai................................. 118

34. táblázat: A kategóriákként használt minőségi tulajdonságok .......................................... 119

35. táblázat: A befektetési preferenciák gyakorisági táblázata verbális protokoll elemzés

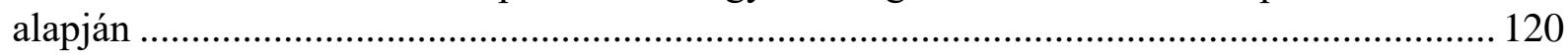

36. táblázat: A 6. fejezet eredményeinek táblázata ............................................................... 127 


\section{Bevezetés}

A gazdaság versenyképességének fenntartása érdekében kulcsfontosságú területe a gazdaságirányításnak az induló (startup-) vállalkozások létrejöttének támogatása, illetve az indulásukat hátráltató tényezők feltárása, megszüntetése. Ezen fiatal vállalkozások finanszírozása igen kockázatos, ezért jellemzően csak saját forrásaikra, barátaik, családjuk befektetéseire és intézményi befektetők egy szük körére számíthatnak, amikor finanszírozási forrást keresnek. A piaci kudarcok viszont hátráltatják a kockázati tőke- és más intézményi befektetőket a legkorábbi életciklusú (úgynevezett „magvető fázisú”) startupok finanszírozásában.

Világszerte elfogadott, hogy a nemzeti innovációs képesség komoly részben a startup-vállalkozások sikeres létrejöttén múlik, és így elkezdtek lépéseket tenni a piaci kudarcok enyhítésére és a tőkepiaci finanszírozási rés („equity gap”) csökkentésére (Wilson et al., 2018) ebben a finanszírozási szegmensben.

Az Európai Unió a Jeremie programmal, a magyar állam pedig több indirekt és direkt állami kockázati tőkeprogrammal igen aktív ebben a szerepben. Mindezek mellett a nagymértékü állami befektetési tevékenység is sok jelentős kutatási témát kínál az elemzőknek. Magyarország a Közép- és Kelet-Európa (KKE) Régió vezető országa volt a kockázati tőkebefektetések összesített értéke alapján 2018-ban (Invest Europe, 2019), komoly részben ezeknek az állami kezdeményezéseknek köszönhetően. Ennél fogva az állami kockázati tőkebefektetés tanulmányozása még indokoltabb Magyarország kontextusában.

A disszertációm célja a startup-ökoszisztéma szereplőinek és az állam befektetői szerepének a bemutatása, az állami beavatkozás okainak, megvalósulásának, az általa kiváltott hatások vizsgálata. Mindezek után lehetővé vált az állami kockázati tőkebefektető által a befektetésekben keresett tulajdonságok beazonosítása is.

A fenti céloknak megfelelően a disszertáció négy logikusan összefüggő fejezetet tartalmaz. Struktúrája holisztikus megközelítést követ, a nagy egészböl indít, és a részelemek felé halad. A disszertáció elején a startup-ökoszisztéma kerül definiálásra és szereplői bemutatásra, majd ezt követi a négy kutatás. A startupökoszisztéma szereplőinek vizsgálatakor kifejezett hangsúly helyeződik a startupvállalkozás alapítóira és az állami kockázati tőkebefektetőkre, akiknek a befektetési preferenciái is feltárásra kerülnek. 
A holisztikus megközelítés elve alapján először a startup-ökoszisztéma kerül definiálásra és szereplöi bemutatásra a 2. Fejezetben. A 3. Fejezetben a startup alapítói - mint az ökoszisztéma központi szereplői - képezik részletesebb vizsgálat tárgyát. A startup alapítóinak demográfiai jellemzői és motivációi is feltárásra kerülnek, a hazai startupok skálázási (,scaling”) stratégiájával, munkahelyteremtő potenciáljával és finanszírozási helyzetével egyetemben. Fontos tanulságokat hoz felszínre az eredmények összehasonlítása a V4 országokban végzett hasonló startupökoszisztéma tanulmányok eredményeivel. Ezután az ökoszisztéma különböző jellemzőit értékelik az ökoszisztéma szereplői. Végül a fejezet bemutatja a legnagyobb kihívásokat, amelyekkel a magyar startup-ökoszisztéma szembesül.

A 4. fejezettől a disszertáció fókusza a kockázati tőkésekre irányul, különös tekintettel az állami kockázati tőkére. A vizsgálatot az állam kockázatitőke-piaci szerepére vonatkozó nemzetközi kutatások szintetizálásával kezdem. A kvalitatív szakirodalmi összefoglaló módszertanát alkalmaztuk. Az adatbázis elkészítéséhez a világ államainak a kockázati tőkepiacok javítására tett erőfeszítéseivel foglalkozó tudományos cikkek megállapításai szolgáltak. Összegyüjtöttük és rendszereztük a nemzetközi eredményeket annak bemutatására, hogy a különböző állami programok miként kezelték a kockázati tőkepiacok problémáit. Bemutatjuk azokat a piaci kudarcokat is, amelyek igazolják az állam belépését a piacra.

Az 5. és 6. fejezetben a disszertáció fókuszát a magyar kockázati tőkepiacra helyezzük vissza, a szélesebb nemzetközi kérdéseket szem elött tartva. Az 5. fejezet először a magyar kockázati tőkepiac korai fejlödésének fázisait mutatja be. Ezt követi a közvetett beavatkozást megvalósító magyar kockázati tőkeprogramok története, különös tekintettel a Jeremie-programra. Ezután a Jeremie program értékelésének bemutatása következik, az előző fejezetben tárgyalt legjobb nemzetközi gyakorlatok összehasonlításával együtt. Ezt követően feltárulnak az állami közvetlen beavatkozás részletei a magyar kockázati tőkepiacon a főbb állami alapkezelő társaságok és kezelt alapjaik tekintetében. A fejezet azon mentőprogramok bemutatásával fejeződik be, amelyekkel az állam a COVID-19 járvány negatív hatásait igyekezik ellensúlyozni.

A 6. fejezet az állami kockázati tőkebefektetők befektetési preferenciáira összpontosít. A szakirodalomban vannak olyan bizonyítékok, amelyek arra utalnak, hogy az állami kockázati tőkebefektetőknek eltérő befektetési preferenciáik lehetnek, amikor kiválasztják a célvállalatokat a befektetésekhez, és ezt érdemes empirikus 
elemzéssel megvizsgálni. Ez a kérdés különösen releváns a magyar kockázati tőkepiacon, az állami befektetések komoly jelenléte miatt. Megvizsgáljuk a magyar kockázati tőkebefektetőket, azonosítjuk a befektetési preferenciáikat, és összevetjük a magán-kockázati tőkebefektetők preferenciáival. Mind a kutatók, mind a startupvállalkozók számára hasznos ez az információ. Verbális protokoll elemzést használtunk módszertanként, mely valós időben képes megragadni a szereplők gondolkodási-döntési folyamatait. A felmérés- vagy interjúalapú módszertant alkalmazó vizsgálatok két fő problémája általánosságban:

- a visszaemlékezési torzítás: a befektetők hamisan emlékeznek korábbi cselekedeteikre;

- a poszt-hoc ésszerüsítés: előzetes megfontolások alapján próbálják igazolni cselekedeteiket.

A valós idejü módszereket a fenti heurisztikák nem befolyásolják. A verbális protokoll elemzés segítségével megmutatjuk, hogy az állami befektetők preferenciái hogyan különböznek a startupok különböző életciklus-szakaszaiban. Ennek még inkább hasznát lehet venni a kutatáshoz a hazai környezetben, mivel a széleskörü állami befektetői jelenlét tapasztalható, és sokféle induló vállalkozás kap támogatást az életciklus minden szakaszában.

A kutatás különös figyelmet fordít a startupok üzleti terveivel kapcsolatos befektetői kritikákra. Számos tipikus hiba kerül feltárásra a különböző dimenziók mentén, ami értékes és hasznosítható információkkal szolgál a kockázati tőkefinanszírozást kereső induló vállalkozók számára.

A 7. fejezet a disszertáció következtetéseit tartalmazza, és további kutatási lehetőségeket mutat be a témában. 


\section{A startup-ökoszisztéma fogalmi keretrendszere}

A startup-ökoszisztéma holisztikus szemléletủ vizsgálata jegyében ebben a fejezetben maga a fogalom kerül meghatározásra és az általa lefedett kör föbb tagjai bemutatásra. A következö fejezetekben két központi alakjával fogok részletesebben foglalkozni: a startupokkal és a kockázati tőkebefektetőkkel.

\subsection{A startup-ökoszisztéma definíciója}

Kiindulópontként a startup ökoszisztéma olyan rendszernek tekinthetö, amely támogatja a fiatal „startup” vállalkozások létrejöttét és fejlődését a különböző finanszírozási formák, valamint nyújtott szolgáltatások révén. A startupökoszisztémának nincs pontos definíciója, mivel a meghatározások tanulmányról tanulmányra változnak, és sokféle jellemzöt tartanak fontosnak. Tripathi és szerzőtársai (2019) a szakirodalmi áttekintés során szám szerint négy különféle ökoszisztéma-definícióval találkoztak. Ezekből azt szürték le, hogy „egy startupökoszisztéma egy adott régió környezetében müködik. Olyan szereplöket von be, amelyek érdekeltekként müködhetnek, például vállalkozókat, befektetőket és más, az ökoszisztémával kapcsolatban önérdekelt embercsoportokat. Együttmüködnek támogató szervezetekkel, például finanszírozó ügynökségekkel, államokkal és oktatási intézményekkel. Szervezeteket hoznak létre egy olyan infrastruktúra megalapozására, amelyben létrejön egy közös hálózat, amely kisebb mértékben képes támogatni és építeni induló vállalkozásokat, valamint növelni a hazai termékfejlesztést és az új munkahelyek nagyobb mértékü létrehozását az országban" (Tripathi et al., 2019, p. 66.)." Ebből a meghatározásból kitünik annak a fontossága, hogy kisebb mértékủ támogatás eredményezzen nagyobb mértékủ bevételeket itthon, ami Magyarországon tartja az egyre képzettebb vállalkozókat és munkavállalókat.

Néhány közös elemet Tripathi és szerzötársai (2019) is azonosítottak 63 cikk alapján: (1) vállalkozó, (2) támogató tényezők, (3) pénzügy, (4) demográfia, (5) piac, (6) oktatás, (7) humántőke és (8) technológia. A vállalkozó és maga a startup, azaz induló vállalkozás ennek a rendszernek a középpontjában áll, ez minden definícióban azonos. Számos olyan ökoszisztéma-tag is van, akik támogatást vagy finanszírozást nyújtanak, vagy mindkettőt az induló vállalkozás számára. Ide tartoznak az inkubátorok, az akcelerátorok, a co-working irodák, a mentorok, a nagyvállalatok, a kockázati tőkések, a közösségi finanszírozás és az állam. A bankokat lehetséges finanszírozóként is említik, de szerepüket minimálisnak és elhanyagolhatónak ítélik 
az ökoszisztémában. Hagyományosan a bankok inkább olyan vállalatoknak nyújtanak hitelt, amelyek erős fedezettel rendelkeznek. A startupok nem ilyenek. A szerzők rámutatnak, hogy a startup-ökoszisztéma definíciói általában egy adott országra, régióra vagy városra korlátozódnak. Fontos elemnek tartják a startup célpiacát is. A legtöbb induló vállalkozás célpiacként tekint a globális piacra, de általában a helyi piacon kell elkezdeniük a müködést. Az oktatás szintén fontos szerepet játszik, mivel a jól képzett vállalkozók befolyásolhatják az ökoszisztéma növekedését. A legtehetségesebbek is igényelnek valamilyen képzést ahhoz, hogy a vállalkozást megkezdhessék. A humántőke a vállalkozók veleszületett képességeit takarja - mint például a tehetséget - amelyek szintén befolyásolják az ökoszisztéma sikerét. Végül a technológiát említik, mivel a legtöbb induló vállalkozás „tech” vállalat kíván lenni, élvonalbeli technológiát alkalmazva a gyors növekedés és a nagy skálázhatóság elérése érdekében. A következő részben közelebbről megvizsgálom a startup-ökoszisztéma tagjait.

\subsection{A startup ökoszisztéma tagjai}

Az előző szakaszban tárgyaltak alapján a startup ökoszisztéma fő tagjai a következők:

1. ábra: A startup ökoszisztéma tagjai

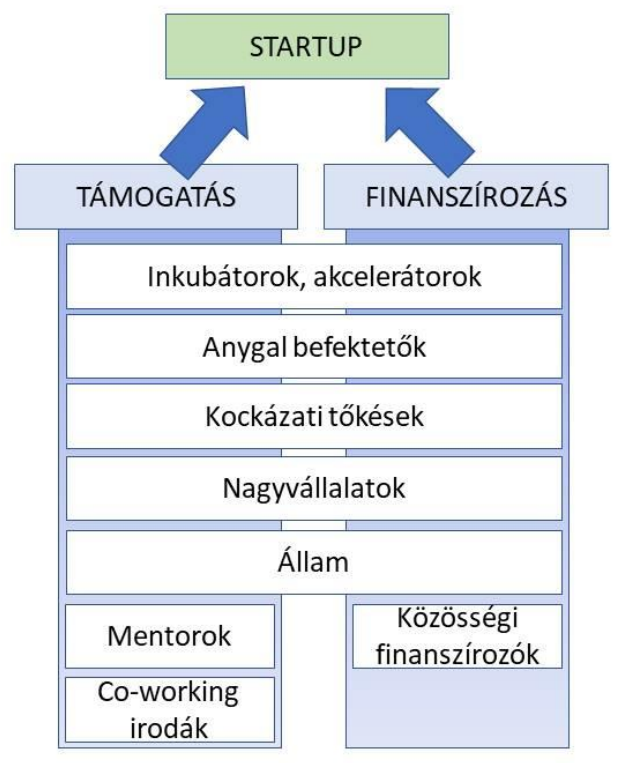

Forrás: saját szerkesztés Tripathi és szerzőtársai (2019) alapján

A startup ökoszisztémának sok tagja van, és mindegyiknek megvan a szerepe az induló vállalatok támogatásában vagy finanszírozásában. A disszertációm középpontjában a startup alapítója (a vállalkozó) és a kockázati tőkebefektető áll, 
különös tekintettel az állami kockázati tőkére. A jellemzőik a későbbi fejezetekben nagyon részletes feltárásra kerülnek, míg az alábbiakban rövid áttekintést adok az ökoszisztéma többi szereplöjéről.

\subsubsection{A vállalkozó és a startup}

A teljes startup ökoszisztéma a vállalkozó és a startup köré épül. A vállalkozó feltár egy piaci lehetőséget, és kész arra, hogy megalapítsa cégét, amely ezen igény kielégítésére hoz létre terméket vagy szolgáltatást. A vállalkozói csapat a projekt elején általában mindössze néhány tagból áll, akik mindegyike az üzlet tervezéséhez vagy a termék létrehozásához szükséges képességeivel járul hozzá a vállalkozáshoz. Ahogy a cég finanszírozást kap, a csapat is általában nő.

A startupperek megismeréséhez először definiálnunk kell, mit is jelent a startup cég fogalma. A 2016-os V4-jelentések (Dzurovčinová, 2016; Kollmann et al., 2016; Skala és Kruczkowska, 2016; Staszkiewicz és Havliková, 2016), valamint a magyar állam által létrehozott Digitális Jólét Program (Miniszterelnökség, 2016) alapján több definíciója is van a startup szónak. A legmegfelelőbb meghatározást a Digitális Jólét Program adja: „a startup nagy növekedési potenciállal rendelkező új céget jelent, vagy olyan projekt-csapatot, amely a vállalkozássá válás vagy a piacra lépés folyamatán indul el” (Miniszterelnökség, 2016, p. 22.)

Ezen fiatal vállalkozások igen kockázatosak, a legtöbbjük néhány éven belül elbukik. Ez azt jelenti, hogy a cégeknek rendkívüli pénzügyi teljesítményt kell várhatóan nyújtaniuk, ha finanszírozást szeretnének kapni, hogy kompenzálják a magas kockázatot. Ezért van, hogy a legtöbb startup cég a technológiai szektorban működik: ilyen termék vagy szolgáltatás esetében jóval könnyebb növelni az üzletet, míg a költségek csak marginálisan növekednek, hiszen a legtöbbjük az interneten keresztül szolgáltat. Ennélfogva egy új ügyfél csak a szolgáltatás létrehozására használt szerver költségeit növeli egy kicsivel. Az üzlet ezen tulajdonsága a skálázhatóság, amely igen kívánatos a befektetők számára.

Szintén fontos megérteni a startupok finanszírozási ciklusát. Berger és Udell (1988) szerint három tényező befolyásolja a cégek finanszírozási lehetőségeit: a méretük, az életkoruk, illetve a róluk elérhető információ mennyisége. Eszerint a legkevesebb finanszírozási lehetőségük a legkisebb, legfiatalabb cégeknek van, amelyekről a legkisebb mennyiségü információ áll rendelkezésre: ők általában barátokra és angyalbefektetőkre számíthatnak. Amikor a cég érési folyamata során 
elér egy bizonyos méretet, ezáltal potenciális befektetési célként szolgál a kockázati tőkebefektetőknek, illetve a magánbefektetőknek. Az életciklus szakaszai közt nem éles a határ. A következőkben csak azok az életszakaszok kerülnek bemutatásra, amelyek jelen kutatásban relevánsak: ezek a startup és a magvető fázis.

1. A „magvető” („seed”) szakaszban lévő cégeknek gyakran mindössze egy termék- vagy szolgáltatásötlet áll birtokában (ez az úgynevezett „ötletcég”). E vállalkozások körét tovább bonthatjuk az alábbi kategóriákra:

- Inkubációs fázis - a termék vagy szolgáltatás létrehozásának $\mathrm{K}+\mathrm{F}$ szakasza. Az e fázisban lévő vállalkozások kevés finanszírozást igényelnek. Az államok általában igyekeznek támogatást biztosítani e szektornak rövid és gyors értékelési folyamat után. Ezt a fázist sokszor „,inkubációs” (,pre-seed”) fázisnak is nevezik.

- A létrehozási fázis során a cég elkezdi a jogi keretek és a müködőképes szervezet felállítását. Ennek a szakasznak a befektetői általában az üzleti angyalok vagy a 3F (Family, Friends, Fools - család, barátok, bolondok) köre. Az utóbbi évtizedben az EU Jeremie-programjának köszönhetően a magvető-alapok és az akcelerátorok is részt vettek az ezen szakaszban lévő cégek finanszírozásában.

2. A ,startup cégek” már kifejlesztettek egy müködőképes prototípust, és piaci visszajelzéssel is rendelkeznek termékükröl vagy szolgáltatásukról. Köztük az alábbi alcsoportokat különböztethetjük meg:

- Bevezetö fázis: a cég müködik, de még nem rendelkezik bevétellel. A kulcsfolyamatok az eladásösztönzés (sales és a marketing).

- Növekedési fázis: ebben a szakaszban a cég elkezd bevételre szert tenni, de még általában negatív eredménnyel rendelkezik. Ezek a cégek a hagyományos privát kockázati tőkealapok kedvelt célpontjai.

- A terjeszkedési fázisban lévő cégeknek már bejáratott üzletük van, de szükségük van többlet-finanszírozásra a marketing célú költésekre, hogy tovább terjeszkedjenek. A kockázati tőkealapok és a magántőkebefektetők a szakasz cégeinek tipikus befektetői. E szakaszban kevesebb állami beavatkozásra van igény, tehát ebben a fejezetben nem ezen lesz hangsúly. 


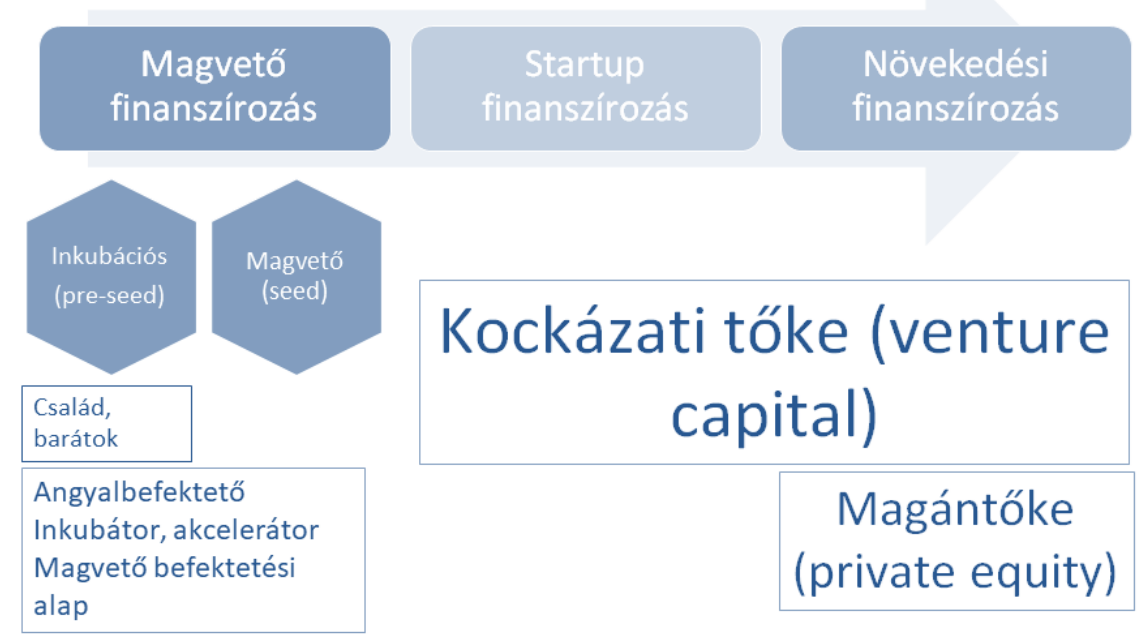

Forrás: saját szerkesztés

A magvető és a legtöbb startup-fázisú cég nem rendelkezik bevétellel. A legtöbbjüknek negatív az eredménye és a pénzáramlása. Ezek a cégek az ötletükön dolgoznak: a termék prototípusán, vagy azon, hogy szolgáltatásukat elérhetővé tegyék ügyfeleik számára. A pénzügyi forrásokat általában a müködési költségek (pl. $\mathrm{K}+\mathrm{F}$, személyes kiadások, marketingköltségek) fedezésére költik. Az új befektetők felkutatásának költségei - ide tartoznak az utazási költségek, a PR-költségek - is jelentősek. Erőteljes marketingtevékenység szükséges az értékesítés fellendítésére. Ezekben a korai szakaszokban a vállalkozások természetesen a kereskedelmi bankok kockázattürésén és figyelmén kívül esnek, így nem számíthatnak sztenderd banki kölcsönökre (Sahlman és Scherlis, 2009; Walter, 2014).

\subsubsection{Inkubátorok és akcelerátorok}

Az ,inkubátor” és az ,akcelerátor” fogalmával kapcsolatban gyakran van félreértés, hiszen e két intézmény hasonló szolgáltatásokat biztosít. Az inkubátorok hagyományosan irodahelységet biztosítottak startupoknak, később üzleti szolgáltatásokkal, például könyveléssel, üzleti tervezéssel és jogi tanácsadással egészítették ki palettájukat, mostanában már korai fázisú befektetéseket is eszközölnek. Az akcelerátorok is befektetnek, ám ők az inkubátorokkal ellentétben a startup gyors növekedésére összpontosítanak szük időkeret alatt. Az akcelerátorok általában intenzív képzéssel és mentorálással segítik a cégeket a gyors növekedés 
éléréséhez az üzleti kapcsolatok szélesítése mellett. A fö különbség tehát a két program között a biztosított támogatás időtartama és módja (Lovas \& Riz, 2015).

Egyre gyakoribbá válik, hogy a kockázati tőkebefektetők akcelerátorokat hoznak létre a legígéretesebb vállalkozások kis összeggel történő finanszírozására, amelyért cserébe egy kisebb részesedésre tartanak igényt. A sikeres cégek ezután folyamodhatnak magvető fázisú befektetésért a kockázati tőkéshez. Ilyen akcelerátorra példa a DBH Investment Zrt. SeedStar-ja, amely akcelerátorként és inkubátorként határozza meg magát.

Lovas és Riz (2015) 18 magyar inkubátorral/akcelerátorral készítettek felmérést, amelyek közül mindössze 6 minősítette magát akcelerátornak, 12 inkubátornak. A következő inkubátorok és akcelerátorok vettek részt a felmérésben: Innonet Innovációs és Technológiai Központ, Agora Office Építőipari Inkubátorház, Digital Factory, iCatapult, Innopark, Kitchen Budapest, Lakits Villa, Makói Ipari Park, Marengo Real Estate, Nagykanizsai Inkubátorház és Innovációs Központ, Nógrád Megyei Regionális Vállalkozásfejlesztési Alapítvány, Oxo Labs, Ózdi Vállalkozói Központ és Inkubátor Alapítvány, Paksi Ipari Park, Prinom Vállalkozói Inkubátorház és Innovációs Központ, Rézgombos Szolgáltató és Inkubátorház, Somogy - Flandria Inkubátorház és Vállalkozásszervező, Traction Labs.

Mindkét csoport tartalmazott nonprofit és for-profit intézményeket is. A kutatásból kiderült, hogy mindkét csoportban változó a támogatás időkerete (amely pár hónaptól 5 évig terjed), ami szintén ellentmond a nemzetközileg elfogadott különbségtételnek az inkubátorok és akcelerátorok közt.

A Nemzeti Kutatási, Fejlesztési és Innovációs Hivatal 4 intézményt ruházott fel Akkreditált Technológiai Inkubátor címmel, valamint az ehhez tartozó támogatással (NKFIH, 2013). A nyertesek a következők voltak: iCatapult (Primus Capital), Aquincum, Digital Factory, ACME Labs. Ezek az intézmények széleskörü akcelerátorprogramot is biztosítanak amellett, hogy névlegesen inkubátorok - ez is azt bizonyítja, hogy a terminológia igen vegyes a területen. Összegzésképp elmondható, hogy a startupok fejlödésük során kapcsolatba kerülnek inkubátorokkal és akcelerátorokkal, és Magyarországon e két kifejezést nagy biztonsággal használhatjuk szinonimákként. 


\subsubsection{Angyalbefektetök}

Az angyalbefektetők olyan vagyonos egyének, akik hajlandók fiatal cégekbe fektetni. Egykor befektetéseik még jóval kisebbek voltak, mint a kockázati tőke, így magvető előtti, illetve magvető fázisú cégeket céloztak meg, akiknek kevesebb befektetésre volt igényük. Mivel az ő célcsoportjuk a legmagasabb kockázatú, egyes angyalbefektetők - diverzifikáció céljából - különböző szektorú céltársaságok között osztják meg befektetéseiket. Ezáltal az angyalbefektetők kiterjedt kapcsolati hálóra tehetnek szert, amelyen keresztül szervezett körülmények között hallgathatják meg a befektetés reményében hozzájuk forduló vállalkozók prezentációit (,pitch-eit”) (Wood et al., 2020).

Az angyalbefektetők látókörében elmozdulás figyelhető meg akár a startup, akár a növekedési fázis felé. A növekedési fázisban akkor fektetnek be, ha az angyalbefektetők csoportjának tagjai kontrollálják a célvállalatot, és ha a befektetők nagyon jól ismerik a szektort. A kockázati tőkésekkel ellentétben az angyalbefektetők „puha” monitorozási rendszert alkalmaznak, amely inkább a cég életében való személyes részvételen, valamint a támogatáson, a bizalomépítésen alapul (Karsai, 2019).

Egyes angyalbefektetők biztonságosabbnak érzik, ha csak arra a szektorra koncentrálnak, amelyben ők maguk is szakértők, így jobban tudnak célvállalatokat választani, és - tudásukat, illetve kapcsolatrendszerüket kihasználva hozzájárulhatnak azok növekedéséhez. A Hungarian Business Angel Network (HunBAN) 2017 óta biztosít strukturált, formális fórumot a magyar angyalbefektetőknek és vállalkozóknak, hogy találkozzanak, és meghallgassák a vállalkozók bemutatkozó pitch-eit. A HunBAN a határon átívelő üzletkötések elősegítése érdekében más közép-kelet-európai angyalbefektetők bevonását is céljául tüzte ki (HUNBAN, 2020).

\subsubsection{A mentorok}

A mentorok olyan tapasztalt egyének az üzleti világban, akik hajlandóak tapasztalataik megosztására a startupokkal. A mentorok tanácsokat adnak abban az üzleti szektorban, amelyben a startup müködik. Felajánlhatják szolgáltatásaikat egyénileg, de szervezeten keresztül is. Ezek a szervezetek lehetnek mentorprogramok vagy olyan szervezetek, akik szolgáltatáscsomagjukban mentorálást ajánlanak. Ide tartozhatnak az akcelerátorok, az inkubátorok, az üzleti angyalok, illetve egyes co- 
working irodák is, amelyek a fejlödő cégeknek mintegy otthont nyújtanak. A mentorok által ajánlott szolgáltatások többek közt a marketingstratégia, a növekedés, a felvásárlás finanszírozása, illetve a döntéshozás területén nyújtott tanácsadás (Tripathi \& Oivo, 2020).

Shimasaki (2020) szerint a személyes, „one-on-one” - típusú mentorálás tulajdonképpen ingyenes, de a mentoráltnak azzal kell kompenzálnia mentorát, hogy tanácsát beépíti, és megmutatja neki, hogy az milyen módon javította vállalkozását. A szerző úgy gondolja, hogy ha egy cégnek több mentora van, az még nagyobb mértékben hozzájárulhat mind a vállalkozás, mind a vállalkozó fejlődéséhez. Bíztat továbbá a formális mentorprogramokban való részvételre; ilyen például a Venture Mentoring Service, ami a Massachusetts Institute of Technology nonprofit szervezete. Ehhez hasonló mentorprogramot indított Magyarország Állama 2019-ben a GINOP keretein belül Országos Vállalkozói Mentorprogram (OVM) néven. Ez ingyenesen biztosít hozzáférést a magyar kisvállalkozások számára egy szervezett mentori kapcsolathálóhoz a Foundation for Small Enterprise Economic Development (SEED) segítségével (OVM, 2020).

\subsubsection{A közösségi finanszírozás}

Az utóbbi években a közösségi finanszírozás („crowdfunding”) is fontos startup finanszírozási formává nőtte ki magát. Ennek keretein belül nagyszámú egyén (a tömeg/közösség) biztosítja a pénzt a cég finanszírozására egy weboldalon véghez vitt fund-raising kampányon keresztül. A közösségi finanszírozásnak több modellje van (Paschen, 2017):

1) az adomány alapú, amely során nem illeti anyagi jutalom a támogatókat;

2) a kölcsön alapú, amelyben a jutalom vagy a befejezett termék, vagy a kamattal kiegészített tőketörlesztés a befizetett töke alapján;

3) a részesedés alapú, amelynek keretein belül a támogatók részesedést kapnak a cégből befizetésükért cserébe.

Utóbbi elterjedése mögött az az ok húzódik, hogy az angyalbefektetők és a kockázati tőkések fejlettebb szakaszokban lévő startupok iránt kezdtek érdeklődni, ez csökkentette a forráskínálatot az induló vállalkozások kezdeti szakaszában (Karsai, 2019).

Csepy és szerzőtársai (2020) a közösségi finanszírozási kampányok sikertényezőit elemezték, és arra a következtetésre jutottak, hogy a kampány 
kezdeményezőjének személyisége és korábbi crowdfundingban szerzett tapasztalatai, az általa használt kommunikációs csatornák (pl. üzenetek vagy videók), illetve az internet alapú kapcsolatok a legfontosabb elemek. Az adomány alapú Betterplace, a GoFundMe, a Crowdfunder; a kölcsön alapú Auxmoney és a Kiváj; illetve a részesedés alapú MicroVentures, a Companisto, a Seedmach és az Indiegogo remek példái a közösségi finanszírozási felületeknek.

\subsubsection{Co-working irodák}

A co-working irodák amellett, hogy fizikai környezetet hivatottak biztosítani a startupok munkájához, ösztönzik a tapasztalatcserét, illetve egymás segítését is. Ezek olyan nagy nyílt irodaterek, amelyekben a startupperek kapcsolatba léphetnek egymással, és ez az interakció a különböző startup-csapatok között szinergiákat eredményezhet (Tripathi et al., 2019).

Az inkubátorok és az akcelerátorok általában biztosítanak co-working irodákat startupjaiknak - a programjuk keretein belül. Tripathi és Oivo (2020) szerint a coworking irodáknak információt, tudást, forrásokat, és a társadalmi tőkéhez való hozzáférést kell biztosítaniuk az ott dolgozók számára. E terek különböző eseményeknek is otthont adnak, hogy felhívják a startupok figyelmét a kínálkozó lehetőségekre.

\subsubsection{Nagyvállalatok}

A nagyvállalatokból hiányzik a startupokra jellemző rugalmasság, míg rendelkeznek a fejlesztéshez szükséges tőkével és piaci tapasztalattal. A startupok ezért az innovációban bizonyos típusú előnnyel rendelkeznek. A startupok egész müködésüket egy innovatív üzleti ötlet fejlesztése köré építhetik, a nagyvállalatoknak jóval nehezebb mobilizálni magukat innovatív irányok felé. Így a nagyvállalatok érdekében áll segíteni a startup-világot és próbálnak profitálni innovációiból.

Weiblen és Chesbrough (2015) 4 modellt mutat, amelyek segítségével létrejöhet a fent leírt interakció. Először is a vállalati kockázatitőke-modellben a vállalat részesedésért cserébe befektet a startupba, ezzel betekintést nyerhet folyamataiba, illetve bizonyos mértékig irányítást is nyerhet fölötte. A második, vállalati inkubációs modellben a vállalat ún. „spinoff”, tehát mellék-startupokat hoz létre belső ötletekből, amelyek nem illeszkednek tökéletesen a cég fötevékenységéhez, azonban továbbfejlesztés, illetve lehetséges későbbi eladás során 
profitot generálhatnak. A másik két modellben nincs szó befektetésről: az „outsidein” (kintről befelé) modell segít a startupoknak olyan megoldások létrehozásában, amelyeket a nagyvállalatok később használhatnak, tehát a startupok siker esetén tulajdonképpen beszállítóvá válnak; míg az „inside-out” (bentről kifelé) modell lehetővé teszi külső szereplőknek, hogy a nagyvállalat szervezetén belül hozzanak létre innovációt, ezzel bevételt szerezve a nagyvállalatnak (pl. applikáció áruházak).

Magyarországon a Nemzeti Agrárgazdasági Kamara a Design Terminallal együttmüködve szervezi a NAK TechLab nevü inkubációs programot 2020. augusztusi kezdettel, melynek során a mezőgazdasággal foglalkozó startupok továbbfejleszthetik termékeiket magyarországi nagyvállalatok (pl. Auchan, Bonafarm, SIÓ, Sygenta) segítségével. A magyar MVM Group energiavállalat MVM Smart Future Lab nevü programján keresztül ajánl inkubációt, illetve kisebbségi részesedés fejében befektetést az energiaszektorban tevékenykedő startupoknak.

\subsubsection{Kockázati tökealap-kezelö társaságok}

A kockázati tőkealap-kezelő cégek pénzügyi közvetítők, tehát tőkét gyüjtenek össze azért, hogy közvetlenül a cégekbe fektessék. Ezek a cégek a magántőke alcsoportjába tartoznak azzal a fö különbséggel, hogy ők az életciklus korábbi szakaszaiban járó startupokra koncentrálnak, míg a magántőke inkább a későbbi fázisúakra (Karsai, 2012). A kockázati tőkalap-kezelők olyan alapokat kezelnek, amelyeket (általában intézményes) tulajdonosai előre meghatározott időintervallumra hoztak létre. Az alapokba tett pénzt vissza kell fizetniük az elért nyereség kíséretében a tulajdonosoknak az alapkezelési díj levonása után. A kockázati tőkealap-kezelő cég és a kezelt alap tehát két külön entitás, a kettő tulajdonosai általában különböznek.

Az alapkezelő cég tulajdonosa lehet magánszemély vagy az állam, és ugyanez igaz a kezelt alapra is. A kockázati tőkealap-kezelő a tőkealap vagyonát fekteti be céltársaságokba. A kockázati tőkések nemcsak pénzügyi befektetést nyújtanak a tőkealapból, hanem saját üzleti kapcsolataikat és szakértelmüket is. Igyekeznek az irányítási jogok megszerzéséhez szükséges részesedést elérni a cégben, illetve a céltársaság vezető és ellenőrző testületeibe delegálják saját tagjaikat. A kockázati tőkebefektetők úgy határozzák meg az általuk megkívánt hozamot, hogy az kompenzálja őket a sikertelen befektetésekért.

Hazai kockázati tőkebefektetőkkel készített interjúk alapján Karsai az elvárt hozamukat 35-50\% közé becsülte, majd 30-40\%-ra 2002-ben (Karsai, 1997, 2002). 
Másrészt a Széchenyi Tőkealap-kezelö Zrt. (Széchenyi Alapok néven müködik tovább 2020. novemberétől), egy állami tulajdonú befektető, 10-20\%-os hozamot kíván meg a cégektől 2 éves müködési múlttal. Ez két tényezőnek köszönhető, amelyek közül az egyik az érettebb társaságok alacsonyabb kockázata, a másik, hogy az állami befektetőkre általánosságban jellemző az alacsonyabb elvárt hozam (SZTA, 2017). A magán és állami kockázati befektetők közti különbség egy későbbi fejezetben lesz bővebben kifejtve.

\section{3 Összefoglalás}

Ez a fejezet a disszertációt a startup ökoszisztéma meghatározásával kezdte, majd megvizsgálta a szereplők szakirodalmi definícióit. E szereplők mind érdekeltek a startup-cégek sikerében, amelyhez vagy szolgáltatás nyújtásával, vagy finanszírozással járulnak hozzá. A siker attól függ, hogy az induló vállalkozás tud-e az ökoszisztéma-tagokkal együttmüködve sikeresen fejlődni. Az inkubátorok szerepe az idők során változott, manapság nem csak helyet biztosítanak a startupoknak, hanem üzleti szolgáltatásokat, illetve befektetést is. Az akcelerátorok célja, hogy rövid idő alatt elősegítsék a gyors növekedés elérését azzal, hogy intenzív tréninget és kapcsolati háló-bővítést kínálnak a befektetés mellett.

Az angyalbefektetők tradicionálisan vagyonos magánszemélyek voltak, akik kis mennyiségeket fektettek be a magvető fázis előtt járó startupokba. A közelmúltban megjelentek szervezett angyalbefektetői csoportok is, akik későbbi fázisú startupokat céloznak meg nagyobb befektetéssel saját érdeklődésüknek megfelelő szektorokban.

A megfelelő mentor megtalálása is nagy szerepet játszhat a startup sikerében ő üzleti és iparági tudását nyújtja a startuppereknek, de befektetést nem. A startupok a közösségi finanszírozási weboldalak segítségével nagyszámú magánszemély pénzügyi potenciálját aknázhatják ki, s ez nemcsak részesedés-alapon történhet, hanem kölcsön- vagy adomány-alapon is. A co-working irodák megosztott irodatereket nyújtanak a startupoknak, és megkönnyítik köztük az együttmüködést.

A nagyvállalatok számos módon profitálhatnak a startupvilágból. Megjelenhetnek befektetőként azon céltársaságoknál, akik a nagyvállalati szektorban végeznek innovációs tevékenységet, létrehozhatnak spinoff-leányvállalatokat azon ötleteik számára, amelyek nem kapcsolódnak szorosan fötevékenységükhöz, segíthetik a startupokat fejlődésükben majd későbbi beszállítóvá válásukban; illetve 
ösztönözhetnek vállalkozásokat arra, hogy az ő saját platformjukon innováljanak, ami által részesedhetnek a nagyvállalat bevételéből. A kockázati tőkealap-kezelő társaságok a befektetőik által biztosított forrásokat kezelik, illetve ők képviselik az egyik legfontosabb intézményes befektetési forrást a startupok számára. Az általuk elvárt hozam jóval magasabb, mint a ténylegesen realizált hozamuk, mivel kompenzálniuk kell az elbukott befektetéseiket is. E társaságok a disszertáció egy fö fókuszát képviselik, így a későbbi fejezetekben részletesebb vizsgálat tárgyát képezik majd. 


\section{A magyar startupperek és a startup ökoszisztéma jellemzői ${ }^{1}$}

Jelen feltáró kutatási fejezet célja, hogy meghatározza a magyar startupperek és az ökoszisztéma fő tulajdonságait. 2017-ben folytattuk le a kérdőíves megkérdezést. Az eredmények összehasonlításra kerülnek a V4-országokban végzett hasonló startup-ökoszisztémát vizsgáló kutatásokkal. Minden, a hazai, vagy a globális piacon megjelenni kívánó startupnak szüksége van egy támogató ökoszisztémára a minél gyorsabb fejlődés érdekében, ez legtöbbször csak a nagyvárosokban érhető el.

Számos tanulmány vizsgálja az új cégek alapításához vezethető tényezőket. Roman és kutatótársai (2018) szignifikáns korrelációt találtak a makroökonómiai mutatók (GDP), demográfiai változók (népesség-növekedési vagy -csökkenési ráta), és a vállalkozói szellem között. A makroökonómiai és demográfiai jellemzők mellett más tényezők és események is támogathatják a startup-vállalkozókat természetes módon. Kérdőívünk szerint a magyar ökoszisztéma szereplői a következő faktorokat gondolták a legerősebbnek a hazai környezetben: közösségi események, co-working irodák, startup-versenyek, mentorok és tanácsadók elérhetősége Magyarországon. Ehhez hasonlóan Timilsina és szerzőtársai (2016) pozitív és szignifikáns kapcsolatokat fedeztek fel az üzleti környezet, a versenyképesség, illetve a cég teljesítménye között. Ám hozzátették, hogy a versenyképességre nagyobb hangsúlyt kell fektetni, ha a cél a cég teljesítményének javítása. Nem elegendő az üzleti környezetet hibáztatni. A magyar startup-ökoszisztéma legfontosabb szereplői maguk a startup-cégek. Bár több definíciónk is van a startup fogalmára, az ökoszisztémával kapcsolatos kutatásokban a startup-vállalkozók akkor kerültek kiválasztásra, ha startup-vállalkozóként határozták meg magukat. Eszerint a kérdőívekben csak azok a cégek vettek részt, amelyek magukat startupként azonosították, és nem történtek további kutatások azt illetően, hogy beleillettek-e volna az előre meghatározott definíciókba. Ebben a kérdőívben a befektetőket a magyar kockázati tőkealap-kezelő cégek vezérigazgatói képviselték.

\subsection{Módszertan és adatbázis}

Ezen kutatás során kérdőíves felmérést alkalmaztunk adatgyüjtési módszerként magyar startupok, kockázati tőkebefektetők, akcelerátorok, inkubátorházak, nagyvállalatok és co-working irodák részvételével. A megkérdezés egy hónapig

1 Ezt a kutatást Jáki Erikával és Kádár Bélával végeztem, a kutatás eredményei a Vezetéstudományban kerültek publikálásra (Jáki et al, 2019) 
folyt, 2017. augusztus 15-től szeptember 20-ig. A kérdőív feleletválasztós, illetve kifejtendő kérdésekből állt. A mintavételi eljárás a nem valószínűségi kényelmi mintavétel módszere volt, amelynek segítségével a kutató arra tesz kísérletet, hogy a startup-ökoszisztéma teljes populációját felkutassa és kitöltesse velük a kérdőívet (cenzus módszer). A startupok megkereséséhez az egyik legnagyobb startupadatbázis, a Crunchbase volt az eszköz. A Crunchbase adatbázis 200 bejegyzett magyar startupot tartalmazott 2017. augusztusában, akiknek a kérdéssor ki lett küldve. A startup-vezérigazgatók és -alapítók e-mailben lettek felkérve a részvételre. A felmérést 66 startup-cég töltötte ki.

A kockázati tőkések elérése céljából a Magyar Kockázati- és Magántőke Egyesület (HVCA) lett felkeresve, amely Magyarországon a magántőke- és kockázatitőke-szektor érdekeit képviseli. 26 HVCA által regisztrált kockázati tőkebefektető volt bejegyezve az adatgyüjtés idején, akik közül 14-en beleegyeztek a kérdőív kitöltésébe.

Fontos volt a magyar inkubátorházak és akcelerátorok felkeresése is. A kétféle támogató intézmény között nincs éles határ. 25 válaszadónkkal majdnem az összes Magyarországon található inkubátorházat és akcelerátort sikerült elérni. Hazánkban kevesebb, mint 10 co-working iroda található, amelyek közül hárommal sikerült felvenni a kapcsolatot: kettővel Budapesten és eggyel Győrben. Az ökoszisztéma 4 nagyvállalatát (két szegedit, egy győrit és egy debrecenit) is sikerült elérnünk.

A tanulmány másik célja, hogy felfedje, a magyar startup-ökoszisztéma tagjai milyen jellemzőket tartanak a legértékesebbnek (6. kutatási kérdés), és mennyire érzik azt, hogy ezek a jellemzők országunkban megjelennek (8. kérdés). A válaszadók egyrészt értékelték a startup-ökoszisztéma 15 jellemvonásának fontosságát 1-5-ig tartó Likert-skálán, ahol az egyes osztályzatok jelentése a következő volt: (1) = egyáltalán nem fontos, (2) = kicsit fontos, (3) = átlagos fontosságú, (4) = nagyon fontos, és (5) = abszolút létfontosságú. Másrészt Likertskálán értékelték a magyar startup-ökoszisztéma jellemzőinek minőségét is az alábbiak szerint: (1) = nagyon gyenge, (2) = gyenge, (3) = elfogadható, (4) = jó, és (5) = nagyon jó.

A Likert-skálák olyan tételegyüttest biztosítanak, amelyek segítségével jellemvonásokat lehet mérni (pl. elégedettség); ezeken a skálákon egyenletesen elhelyezett számok szerepelnek (leggyakrabban 1-5-ig) és egyenletesen elhelyezett válaszlehetőségek. A Likert-skálát aggregált skálaként tartjuk számon, mivel több 
ugyanazt a jellemzőt mérő Likert-típusú tételt lehet együtt, aggregált formában értékelni. A statisztikusok körében konszenzus van azt illetően, hogy a Likertskálákat az elemzés kedvéért folytonosnak lehet tekinteni, amíg az adott elemzési eszköz feltételezései nem sérülnek (Harpe, 2015). Labovitz (1967) megmutatta, hogy a Likert-típusú lineáris és monoton tételeket lehet viszonylag kis hibaszázalékkal elemezni. Azokban a tanulmányokban, amelyekben előnyösebb egyedi Likert-típusú tételeket (kérdéseket) elemezni, mint a kombinált skálát használni, azokban intervallum-alapú statisztikát használnak (Aranyossy et al, 2018).

Vizsgáljuk a mintaátlagot, a mediánt és a móduszt, valamint a (4) és (5) válaszok gyakoriságát, hogy kiértékeljük a startup-ökoszisztéma fontosságáról és megítéléséről adott válaszokat. Emellett ahhoz, hogy meg tudjuk határozni, a különböző ökoszisztémabeli alcsoportoknak eltér-e a véleménye a tényezők bármelyikét illetően, először egy egyirányú ANOVA tesztet végeztünk el a tényezőkön, hogy lássuk, vannak-e meghatározó különbségek a csoportok között 5\%-os szignifikancia szinten. Ezek után azon elemeken, amelyek esetében szignifikáns különbség volt a csoportok között, Hochberg-féle post-hoc teszt lett lefuttatva, amely nagyon jól kezeli a különböző méretü almintákkal rendelkező mintákat, feltéve, hogy az alminták közti variancia homogén, ami esetünkben igaz. Ez a teszt megmutatja, hogy amely alcsoportoknak van szignifikánsan eltérő véleménye a jellemzők fontosságát és megítélését illetően. A központi tendencia mértékei hasonló eredményeket mutat a 5. táblázat és a 7. táblázat tényezői esetében, amely egybevág a (4) és (5) válaszok gyakoriságával.

\subsection{Kutatási kérdések}

Mivel a startupoknak skálázhatónak kell lenniük, az IT-startupok, társaikkal szemben, előnyös pozíciót szereztek. Így könnyen feltételezhető az, hogy a legtöbb startupper számítástechnikai háttérrel rendelkezik, némileg szükölködik üzleti és pénzügyi ismeretekben, és segítségre szorul az üzleti tervének elkészítésében, a finanszírozás elnyerésében, és a cége értékének meghatározásában. Kilenc kutatási kérdést határoztunk meg a magyar startup-ökoszisztéma feltérképezésére (lásd: 1. táblázat). A kutatásban összehasonlítjuk a startup ökoszisztéma jellemzöit a többi V4 ország startup ökoszisztémájával is. 
1: Melyek a magyar startupperek fő demográfiai jellemzői?

2: Melyek a magyar startupperek fő motivációs tényezői a startup-alapítók kora és neme szerint?

3: A startupok szerint, melyek a cég skálázásának fő kihívásai?

4: Mekkora a magyar startupok munkahely-teremtési potenciálja?

5: Melyek a magyar startupokat finanszírozó fő pénzügyi források?

6: A startup-ökoszisztéma mely tényezőit tartják annak tagjai a legfontosabbnak?

7: Vannak jelentős véleménybeli különbségek az ökoszisztéma tagjainak alcsoportjai között ezen tényezők fontosságát illetően?

8: Hogy értékelik a magyar startup-ökoszisztémát annak tagjai az egyes jellemzők mentén?

9: Vannak jelentős véleménybeli különbségek az ökoszisztéma tagjainak alcsoportjai közt ezen tényezők értékelését illetően?

\section{Forrás: saját szerkesztés}

A tanulmány egyik célja, hogy felderítse, valójában kik a magyar startupperek, milyen motivációk hajtották őket a startup-világ felé, mely fő kihívásokkal néznek szembe, és honnan nyernek finanszírozást (1-3. és 5. kérdések). Szintén érdemes megfigyelni a magyar startupok munkahelyteremtő potenciálját, hiszen ez gyakran használt érv az állami startup-finanszírozásba történő beavatkozás mellett, amely Magyarországon valóban jelentős (4. kérdés). Az eredményeket a többi V4-es országban készült startup-ökoszisztémát kutató felmérésekkel vetettük össze. Másrészt a magyar startup ökoszisztéma egésze nagy jelentőséggel bír, pontosabban azt érdemes megvizsgálni, hogy annak mely tényezőit tartják a tagok a legfontosabbnak, és hogyan értékelik a magyar startup-ökoszisztémát ezen tényezők mentén (6-9. kérdés).

A vizsgálat logikája alapján propozíciók is kialakultak (lásd az alábbi táblázatot). A tanulmány kockázati tőkebefektetők, akcelerátorok, inkubátorok, coworking irodák és cégek véleményét tartalmazza a téma minél jobb megvilágítása érdekében.

2. táblázat: Propozíciók a 3. fejezethez

1a propozíció: A magyar startupperek budapesti frissdiplomások. 1b propozíció: A profit a startup létrehozásának fő motivációja.

2a propozíció: A magyar startupok számára a nemzetközi növekedés a legnagyobb kihívás. 2b propozíció: A magyar startupok munkahely-teremtési potenciálja jelentős.

2c propozíció: A magyar startupok fö finanszírozási forrása a kockázati tőke bevonása. 2d propozíció: A hazai startup-ökoszisztéma a legfontosabb tulajdonságokat tekintve 
hasonló a többi V4-es ország startup ökoszisztémájához

3a propozíció: A magyar startup ökoszisztéma tagjai a finanszírozáshoz való hozzáférést tartják a startup ökoszisztéma legfontosabb elemének.

3b propozíció: Nincsenek jelentős véleménybeli különbségek az ökoszisztéma-tagok alcsoportjai között a startup ökoszisztéma tényezőinek fontosságát illetően.

4a propozíció: A magyar startup ökoszisztéma tagjai a finanszírozáshoz való hozzáférést tartják a magyar startup ökoszisztéma legerősebb tulajdonságának.

4b propozíció: Nincsenek jelentős véleménybeli különbségek az ökoszisztéma tagok alcsoportjai között a magyar startup ökoszisztéma tényezőinek értékelését illetően.

\section{Forrás: saját szerkesztés}

\subsection{A magyar startupperek jellemzői}

Ez a szekció az 1. kutatási kérdésre válaszol: melyek a magyar startupperek fő demográfiai jellemzői?

A kérdöív eredménye alapján a startup-cégek vállalkozói főként a 26-35 közötti (38\%), illetve a 36-50 közötti (42\%) korosztály képviselői, együtt az összes startupper 80\%-át kitéve. Összehasonlításképp Csehországban, Lengyelországban és Szlovákiában a startupok alapítói általában a 30-as éveikben járnak (Beauchamp \& Skala, 2017). A startupperek mindössze 9\%-a tagja a 19-25-ös korcsoportnak, és 11\%-uk 50 év fölötti. Korosteleva és Mickiewicz (2011) is vizsgálták a startup vállalkozók kor szerinti eloszlását, és megállapították, hogy a projekt pénzügyi léptéke annál nagyobb, minél idősebb a vállalkozó. Ez arra mutat, hogy az idősebb vállalkozók nagyobb tapasztalata, már megalapozott hírneve, felhalmozott megtakarításai növelik a pénzügyi források sikeres bevonásának esélyét.

Kérdöívünk szerint a startupperek $85 \%$-a férfi és csak 14\%-a nő, tehát a nők igen alulreprezentáltak a startupperek között. Ez nemzetközi trend: az Európai Startup Monitor 2016-os kutatása szerint kontinensünkön a női startup-alapítók aránya mindössze 14,8\% (Kollmann et al, 2016). A nemi összetételt tovább kutatva láthatjuk, hogy az esetek 32\%-ában legalább egy női alapító volt a válaszadó startup csapatokban.

A felmérésböl kiderül, hogy a startupperek 83\%-ának van felsőoktatásban szerzett diplomája, 53\%-nak mesterdiplomája. Csehországban, Lengyelországban és Szlovákiában a startupok alapítóinak legalább kétharmada rendelkezik felsőfokú képesítéssel (Beauchamp \& Skala, 2017). A mesterdiplomások körét tekintve a csoport 6,1\%-a $\mathrm{PhD}$ diplomát is, 7,6\%-a MBA diplomát tudhat magáénak. A válaszadó startupperek 16,7\%-a jelölte meg, hogy még középfokú oktatási intézmény tanulója. Lengyelországban az alapítók 13\%-a rendelkezik PhD diplomával (Skala \& 
Kruczkowska, 2016). Mint az a következö grafikonról is kitünik, a startupperek közt a legtöbb MA/Msc diplomás (39\%), a második legnagyobb csoport a BA/BSc diplomásoké (30\%). A csak érettségivel rendelkező vállalkozók köre is jelentős (17\%), míg a $\mathrm{PhD}$ vagy MBA diplomások a válaszadó startupperek mindössze 6\%át, illetve $8 \%$-át teszik ki.

A saját maguk által közölt motivációik alapján az eloszlás a következőnek tulajdonítható: a válaszadók általánosságban nem elégedettek a vállalati életvitellel, amelybe belekényszerültek, és az őket alkalmazó vállalatok profitjához arányosított fizetésükkel sem. Ezen kívül nagyobb alkotói szabadságra vágynak. Ezek mind azt mutatják, hogy a válaszadók előzőleg vagy jelenleg beosztott pozíciókban dolgoztak/dolgoznak viszonylag alacsony bérért, repetitív feladatokat végezve. Ezek az emberek nagyrészt rendelkeznek BA/BSc- és MA/MSc-diplomával, és úgy érzik, hogy magasabb szintü feladatok elvégzésére is képesek, mint amelyeket a vállalati pozíciójuk megkövetel tőlük. Ezen kívül a startupperek kis százaléka MBA diplomás, amely annak lehet köszönhető, hogy sok MBA-diplomával rendelkező személy magas beosztásban dolgozik, amelyben minden képességét és energiáját használhatja. Ennek eredményeképp nincs sem energiájuk, sem motivációjuk, hogy más szakmai projektekbe kezdjenek, például startupokba. A PhD-diplomások szintén nagyon elfoglaltak, hiszen újabb és újabb kutatási cikkeket kell írniuk, egyetemükön kell oktatniuk, és általában az egyetemen kívül is folytatnak tanácsadói és oktatási tevékenységet - ez magyarázza, hogy a startuppereknek miért csak egy kis része PhD-diplomás (Herzberg, 2017).

3. ábra: A magyar startup-ökoszisztéma startuppereinek legmagasabb képzettsége

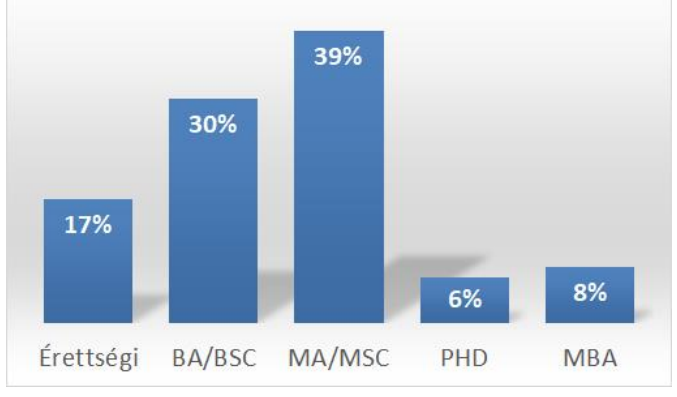

Forrás: saját adatbázis 
Kérdőívünk alapján a magyar startupperek 47\%-a társadalomtudományi területen szerzett képesítést. A társadalomtudományok területén belül 64\%-ot tesznek ki a közgazdaságtudományokban, 9\%-ot a marketingben, 6\%-ot az általános üzleti tanulmányokban, 10\%-ot a pénzügyben, és 11\%-ot az egyéb területeken képzett válaszadók. A mérnöki tanulmányok jóval kisebb mértékben részesednek (22,7\%), az informatikai tanulmányok 10,6\%-ot tesznek ki, a müvészetek és a természettudományok 3-3\%-ot.

4. ábra: A startupperek képesítésének területei

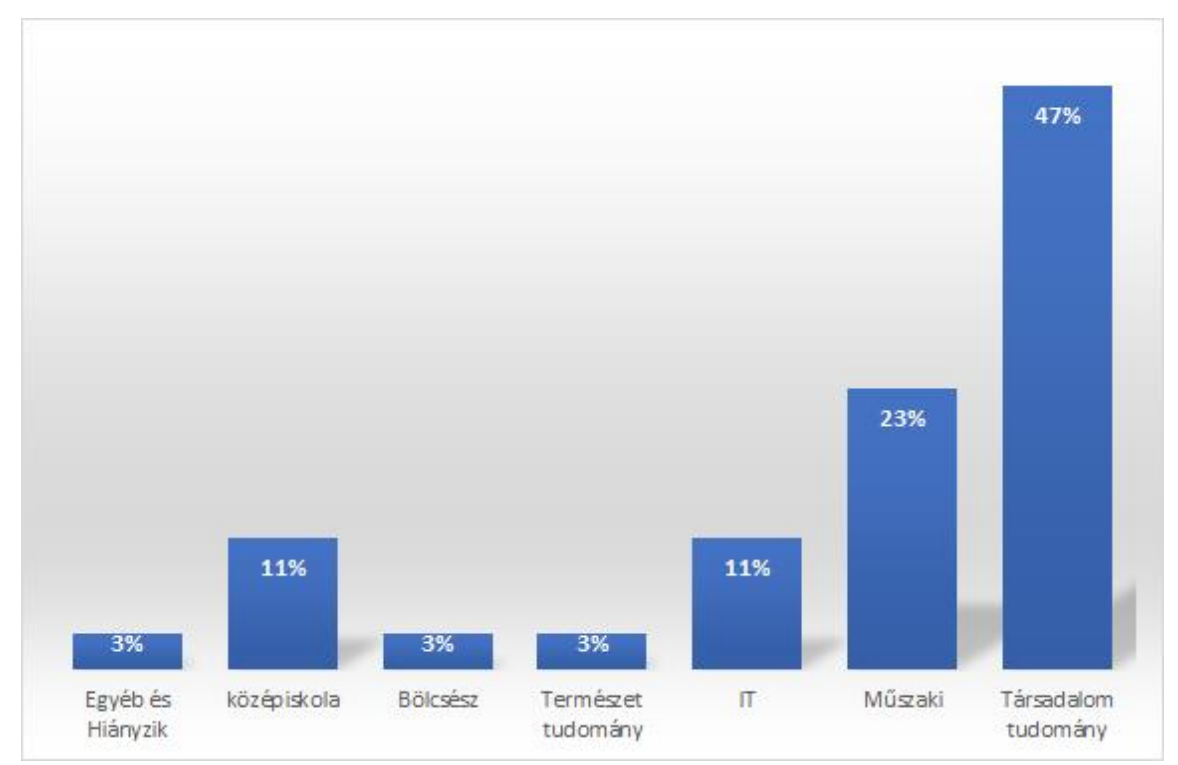

Forrás: saját adatbázis

A startupperek szerint a következő képességek és ismeretek elengedhetetlenek a sikeres startup-indításhoz: általános üzleti ismeretek, projektmenedzsment, marketing, PR, értékesítői készségek. A következő területeket is életbevágónak tartják: jog, info-kommunikációs technológiák, big data és üzleti elemzés.

A kérdőívet kitöltő startupok 79\%-a budapesti alapítású és müködésű. Miskolc (7\%) a második legkedveltebb hely startup alapításához. Összességében a válaszadóknak csak 21\%-a nem fövárosi illetőségü. Hasonlóképpen, Lengyelországban a legtöbb startup Varsóban található, amelyet Wroclaw és az ún. Hármasváros (Gdansk, Sopot, Gdynia) követ a sorban (Morawska, 2015). A legtöbb szlovákiai startup is a fövárosban, Pozsonyban müködik (Dzurovčinová, 2016), Csehországban pedig Prágában, amelyet Brno követ (Staszkiewicz \& Havliková, 2016). Általánosságban tehát elmondható, hogy a V4-országokban a startupok a fővárosokban koncentrálódnak. 
5. ábra: A startupok székhelyei

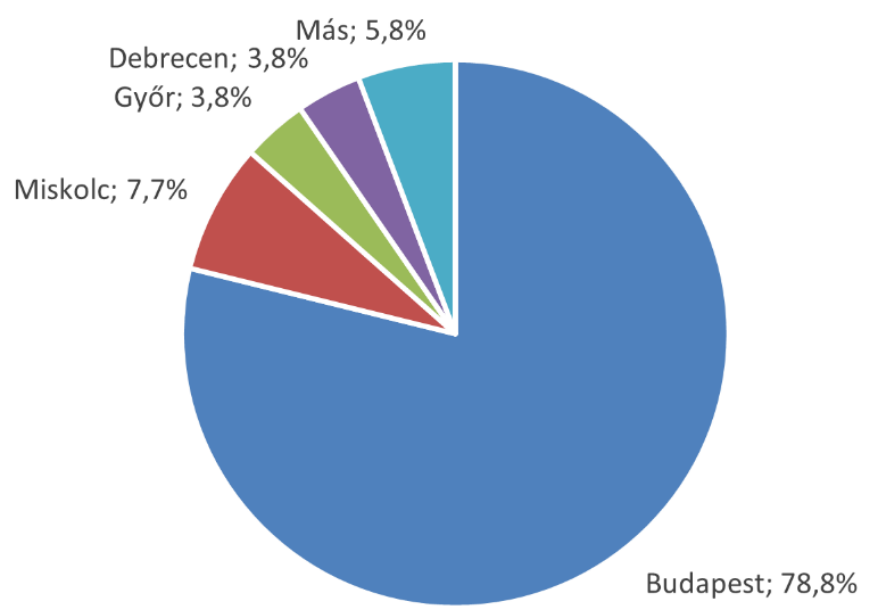

Forrás: saját adatbázis

A magyar startup-ökoszisztéma részvevői szerint Budapest a legvonzóbb város a közép-kelet-európai régióban, amelyet Prága, Pozsony és Bécs követ, illetve Varsót, Krakkót és Berlint is említik.

A kérdöív alapján levonhatjuk azt a következtetést, hogy a magyar startupperek főleg középkorú budapesti férfiak, akik társadalomtudományi, mérnöki vagy informatikus BA/BSc vagy MA/MSc diplomával rendelkeznek, illetve akik korábban céges állásban dolgoztak. Így az la propozíciót - „A magyar startupperek budapesti frissdiplomások" - csak részben támaszthatjuk alá, hiszen a startupperek - bár tényleg föként budapestiek - nem frissdiplomások.

\subsubsection{A startupok létrehozásának motivációi}

Vizsgáljuk most meg a startupok elindításának kiváltó okaiban mutatkozó különbségeket az alapítók korcsoportjai és neme szerint. A válaszok alapján a következő motivációs kategóriák rajzolódtak ki:

- Fiatal és merész;

- Küldetéstudat;

- Önmegvalósítás;

- Autonómia, függetlenség. 
Az 3. táblázat és 4. táblázat tartalmazza a női és férfi almintákat. Mivel 57 férfi és csak 9 női válaszadó volt a startup csapattagok között, a férfi almintában sokkal jobban lehet általánosítani.

3. táblázat: A startupok indításának motivációi - nők esetén

\begin{tabular}{|l|c|}
\hline Kor/Nem & Nők $(\mathrm{n}=9)$ \\
\hline $\mathbf{1 9 - 2 5}$ & $\begin{array}{c}\text { Fiatal és merész: “Több szabadság és szabad idö”, "kihívást jelentő } \\
\text { munkával rendelkezni” }\end{array}$ \\
\hline $\mathbf{2 6 - 3 5}$ & Önmegvalósítás: a siker vágya, saját ötlet jutott eszébe \\
\hline $\mathbf{3 6 - 5 0}$ & $\begin{array}{c}\text { Önmegvalósítás: “Tapasztalataim alapján innovatív ötletem született” } \\
\text { vagy „Hiszek az ötletemben, meg kellene valósítani” }\end{array}$ \\
\hline
\end{tabular}

Forrás: saját adatbázis

4. táblázat: A startupok indításának motivációi - férfiak esetén

\begin{tabular}{|c|c|}
\hline $\begin{array}{c}\text { Kor/ } \\
\text { Nem }\end{array}$ & Férfiak (n=57) \\
\hline $\mathbf{1 9 - 2 5}$ & Fiatal és merész \\
\hline $\mathbf{2 6 - 3 5}$ & $\begin{array}{c}\text { Önmegvalósítás: "Meg akarom valósítani az ötletemet", “új dolog } \\
\text { létrehozásának függősége" "gyakorlatba ültetni az álmomat", "legyen egy jó } \\
\text { csapat, akikkel dolgozom" } \\
\text { Küldetéstudat: "valami állandót, örökkévalót alkotni" }\end{array}$ \\
\hline $\mathbf{3 6 - 5 0}$ & $\begin{array}{c}\text { Autonómia, függetlenség: "nagyobb részt kapni a profitból", "elegem van a } \\
\text { vállalati életstílusból" } \\
\text { Küldetéstudat: "valami értékeset létrehozni" } \\
\text { Önmegvalósítás: "megvalósítani egy ötletet", "vállalkozónak születtem" }\end{array}$ \\
\hline
\end{tabular}

Forrás: saját adatbázis

A motivációról szóló válaszok alapján fontos megvizsgálni, milyen is egy tapasztalt startup-vállalkozó. Részben elegük van a multinacionális cégek atmoszférájából. Stadnicka és Sakano (2017) szerint a multinacionális vállalatoknak motiválniuk kellene alkalmazottaikat arra, hogy az innováció és az értékteremtés részévé váljanak, de ez a viselkedés alig jelenik meg a magyar piacon. A 36-50-es korcsoportban néhány férfi válaszadó „született vállalkozóként” jellemezte magát, ami arra mutathat, hogy e csoport vállalkozói elérték a szakmájuk csúcsát.

Az $1 b$ propozíció - „A profit a startup létrehozásának fö motivációja” részben alátámasztásra talált, mivel a pénzügyi nyereség valóban szerepet játszik, azonban csak csekélyet; a szabadság, a kihívás és az innovatív ötletek 
megvalósításának vágya a meghatározó motivációs tényező mind a férfiak, mind a nők között.

A vállalkozói tapasztalatot tekintve fontos tudni, hogy a startupperek már részt vettek-e elbukott startup kísérletben, vagy sem. 40\%-uk már vállalt szerepet legalább egy sikertelen startupban, de csak $14 \%$ vett részt egynél többen. Szlovákiában az alapítók 36\%-a müködött már közre sikertelen startupban, amely arány nagyon hasonló a magyar eredményhez (KPMG, 2016).

Egy másik fontos tényezője a „született vállalkozónak” vagy a vállalkozói tapasztalatnak a startupper jelenlegi munkája. A kitöltők az alábbi válaszok valamelyikét választhatták: diák vagyok; szabadúszó vagyok; teljes állás mellett dolgozom a startupomon; részt veszek egy vagy több üzletben; a startupom a teljes munkaidős állásom. A válaszadók 35\%-a a startupját tartja teljes munkaidős állásának, 25\%-uk egynél több startupban vesz részt. 17\% menedzseli startupvállalkozását teljes állás mellett. Csak $9 \%$ foglalkozik üzletével tanulmányai mellett, és $14 \%$ szabadúszó.

\subsubsection{Növekedési stratégia}

A startupok növekedési stratégiája az, hogy ügyfeleik számát növelik hazai, regionális és globális szinten a marginális költségek alacsonyan tartása mellett. Ez a szekció azt vizsgálja, hogy miket tartanak a startupok a legnagyobb kihívásoknak az üzlet skálázása során (3. kérdés). A startupok általában interneten és a kliens saját elektronikai eszközén keresztül (PC, tablet, okostelefon) nyújtják szolgáltatásukat. Könnyebb „skálázni” internet alapú termékkel/szolgáltatással rendelkező vállalkozást, mint fizikai termékkel rendelkezőt. Az IT szolgáltatások eladásának növelésekor a legnagyobb pluszköltség az új szerverek megvásárlása vagy az új ügyfélszolgálati munkatársak felvétele. Azonban, ha egy gyártó cég kívánja növelni az értékesített mennyiségét, akkor szükség lehet új gyártósorok vásárlására vagy akár gyárak építésére, mindez nagy összegű befektetéssel jár. A fizikai termékek gyártásának határköltsége szintén jóval magasabb, mint egy IT-startup határköltsége. Következményképp a startupok ügyfélbázisukat és bevételüket viszonylag alacsony extra befektetéssel növelhetik, feltéve, hogy a termékük vagy szolgáltatásuk skálázható és a cég megfelelö növekedési stratégiával rendelkezik.

Szintén kérdéses, hogy hasznos-e a gazdaság egésze számára, ha a finanszírozott startupok túlnyomó része az információs technológiában müködik. Ez 
sok újszerü üzleti ötlet megvalósítását korlátozza a gyártó- illetve egyéb szektorokban, amelyek szintén jelentős munkaerőt igényelnének. Ez sajnálatos módon limitálja a klasszikus startupok munkahelyteremtő potenciálját, ami a következő alfejezetben képezi részletesebb vizsgálat tárgyát. A technológiai startupok dominanciájával kapcsolatban a másik probléma, hogy a hardver-startupok egyre nehezebben tudnak finanszírozáshoz jutni. Számukra sokkal költségesebb prototípust fejleszteni, általában alacsonyabb a haszonkulcsuk és kevésbé skálázhatóak. Így egyre többször folyamodnak közösségi finanszírozásért ahelyett, hogy szoftver-startupokkal versenyeznének kockázati tőkéért. Az állami támogatású kockázati tőkebefektetők segíthetnének a hardver-startupok finanszírozásában, növelve ezzel a startup szektor munkahelyteremtési potenciálját.

A felmérésben a startupperek 73\%-a állította, hogy van növekedési stratégiája. Az ezt fenyegető legnagyobb kihívások az alábbiak voltak: finanszírozás, új piacokra való betörés és a disztribúciós csatornák hiánya. Mivel Magyarország kicsi és nyitott gazdaság, a startupok számára létfontosságú, hogy külső piacokra törjenek be, hogy méretgazdaságos működést tudjanak kialakítani befektetési idő alatt. A kérdőív alapján a legtöbb magyar startupper szerint a nemzetközi piacokhoz való hozzáférés az a faktor, amely legnagyobb hatással van cégük növekedési potenciáljára. Ebből következően a startupperek 50\%-a ezeket a tevékenységeket jelölte meg a következő év prioritásaiként: értékesített mennyiség növekedése és új piacokra való behatolás. Bár a legtöbb startup tervezi müködését külföldre kiterjeszteni, a válaszadók mindössze 10\%-a jelezte, hogy legalább egy külföldi alapítója van. A startupperek 60\%-ának van segítségre szüksége a külföldi piacra történő belépéshez. A V4országokban is számottevően jelen van a nemzetközi piacok megcélzása: Csehországban a startupok 75\%-a exportál javakat vagy szolgáltatásokat (Staszkiewicz \& Havliková, 2016), Szlovákiában a 79\%-uk fókuszál az exportra (Dzurovčinová, 2016). Lengyelország az a V4-tagország, amely méretének és népességének köszönhetően megengedheti magának, hogy hazai piacára koncentráljon legjobban: itt a startupoknak csak fele végez export-tevékenységet (Skala \& Kruczkowska, 2016).

Ezen kívül egyfelöl a startupoknak az értékesítési tevékenységükre is figyelniük kell. Másrészről a termék vagy szolgáltatás folyamatos fejlesztésre szorul, főként az első három évben. A következő év prioritásaként a termékfejlesztést a cégek 50\%-a jelölte meg. A felmérésben feleletválasztós kérdések kerültek 
alkalmazásra, hogy azonosítani lehessen azt a területet, amelyen a startupperek úgy gondolják, segítségre szorulnak.

6. ábra: Tevékenységek, amelyekhez a startupperek segítséget igényelnek

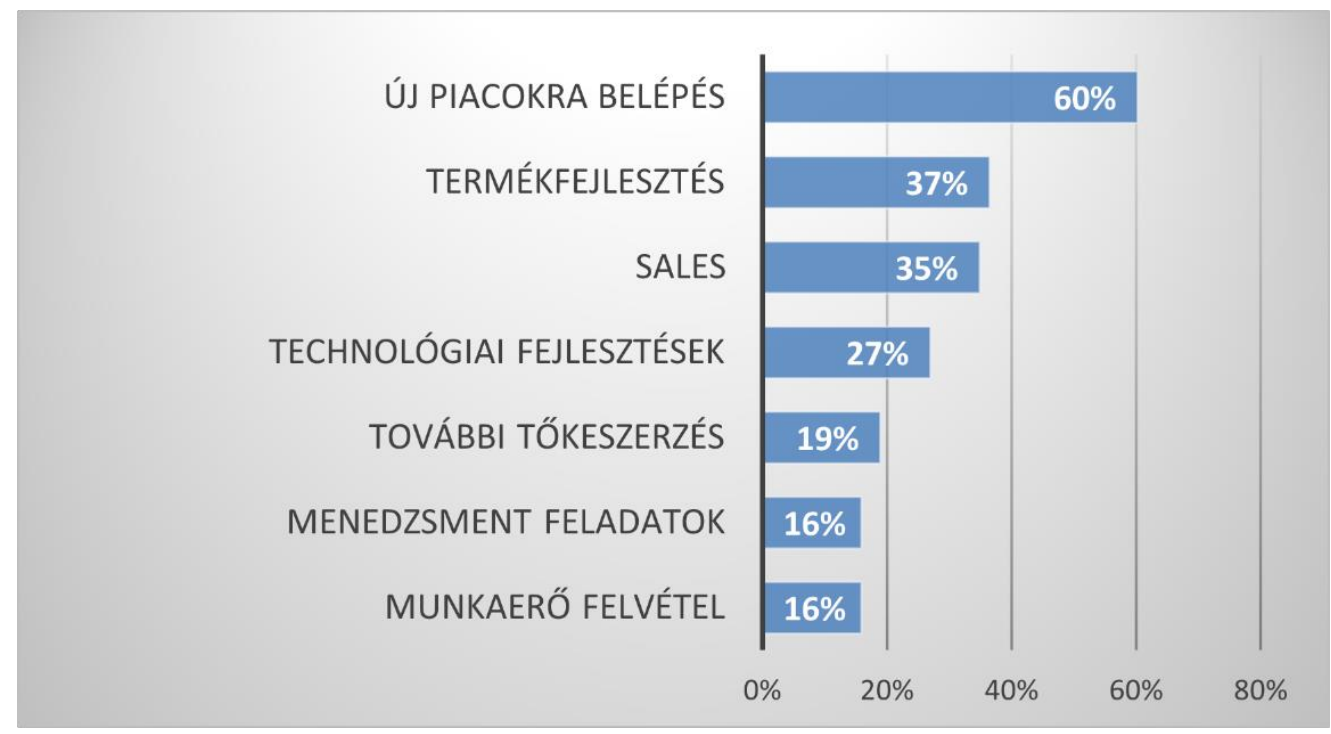

(Forrás: saját adatbázis)

Az új piacokra való belépés az a tevékenység, amelyben a startupperek legtöbbje szorul segítségre. Mivel a startupok az új piacokra történő belépést jelölték meg a skálázás legnagyobb kihívásaként, a 2 a propozíció - „A magyar startupok számára a nemzetközi növekedés a legnagyobb kihívás" - támogatásra talált. Ezt követi a termékfejlesztés, az értékesítés növelése, majd a technológiai fejlesztés. A finanszírozás elnyeréséhez csak 19\% szeretne külső segítséget használni, és csak 16\%-nak van segítségre szüksége a szervezetfejlesztéshez és a munkaerő bővítéséhez. A további eredmények megfelelnek a tanulmány képzettségről szóló részének. Nagyjából $50 \%$ végzett álalános üzleti tanulmányokat, és csak $11 \%$ informatikus. Ez megmagyarázza, miért van a startuppereknek szüksége segítségre nagyrészt a termék- és technológiai fejlesztés területén. A kérdőív alapján a startupperek 20\%-a tartja Magyarországot a fő piacának, és 70\% gondolja úgy, hogy termékére/szolgáltatására lesz kereslet a globális piacon is. A startup alapítóknak gondoskodniuk kell arról, hogy az alapítók között már a projekt kezdetén legyen technológiai szakértő, aki felelős lesz a termék vagy szolgáltatás fejlesztéséért. 


\subsubsection{Munkahelyteremtés}

A startupok egyik jól ismert pozitív externáliája a munkahelyteremtés, melyet sokszor jelölnek meg okként az állami beavatkozás indoklására a startupok finanszírozásának piacán. A munkahelyteremtés nem csak új munkavállalók felvételével történik, hanem maguk az alapítók is tekinthetők alkalmazottnak. Most a magyar startupok munkahelyteremtő potenciálját fogjuk megvizsgálni (4. kérdés). A kérdőív alapján a startupok 35\%-ának 2-nél több alapítója van, 38\%-ának 2 alapítója, 27\%-ának csak 1.

\section{7. ábra: Alapítók száma}

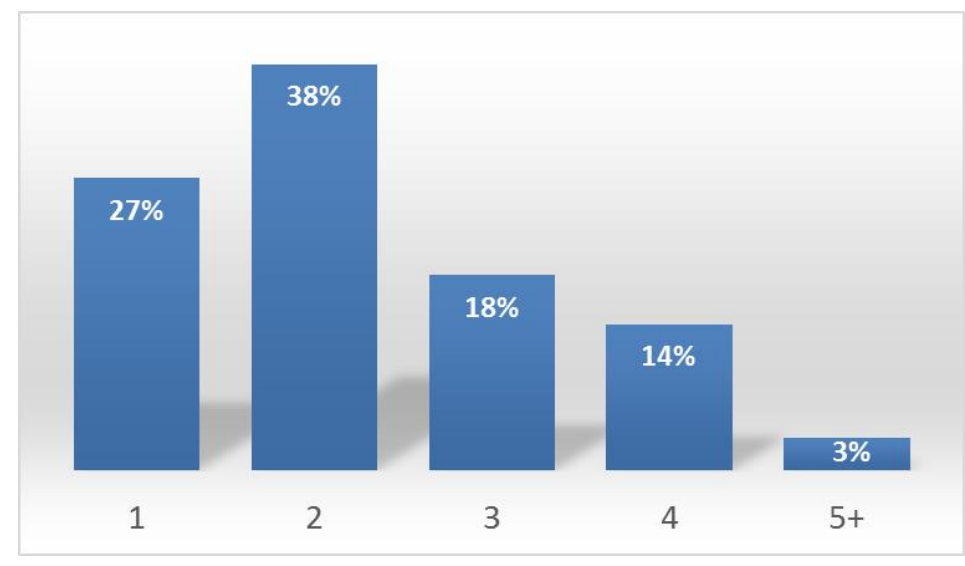

Forrás: saját adatbázis

A startupok csak 21\%-a nem rendelkezett egy alkalmazottal sem. Tradicionálisan az alapítók végzik az összes munkát a cég megalapítását követő időszakban, és ahogy a cég nő, úgy vesznek fel új munkavállalókat. A legtöbb megkérdezett cégben (43,9\%) 1-3 alkalmazott van. A startupok 81,8\%-a kevesebb, mint 10 föt alkalmaz. Ez a cégméret tipikus a korai fázisú startupok esetében. Lengyelországban a 10 alkalmazott alatti startupok 59\%-ot tesznek ki (Skala and Kruczkowska, 2016), Szlovákiában 63\%-ot (Dzurovčinová, 2016), Csehországban 90\%-ot (Staszkiewicz \& Havliková, 2016). A kérdőívünk eredménye így a középmezőnyben helyezi el Magyarországot a V4-országok között.

Emellett a vizsgált startupok 18,2\%-a több, mint 10 alkalmazottat foglalkoztat, ami azt jelzi, hogy a magyar piacon szép számmal vannak jelen fejlettebb fázisú startupok is. Két startup alkalmazott különösen magas számú munkavállalót (40, valamint 50 főt), ez a cégméret általában többkörös befektetés után érhető el. 


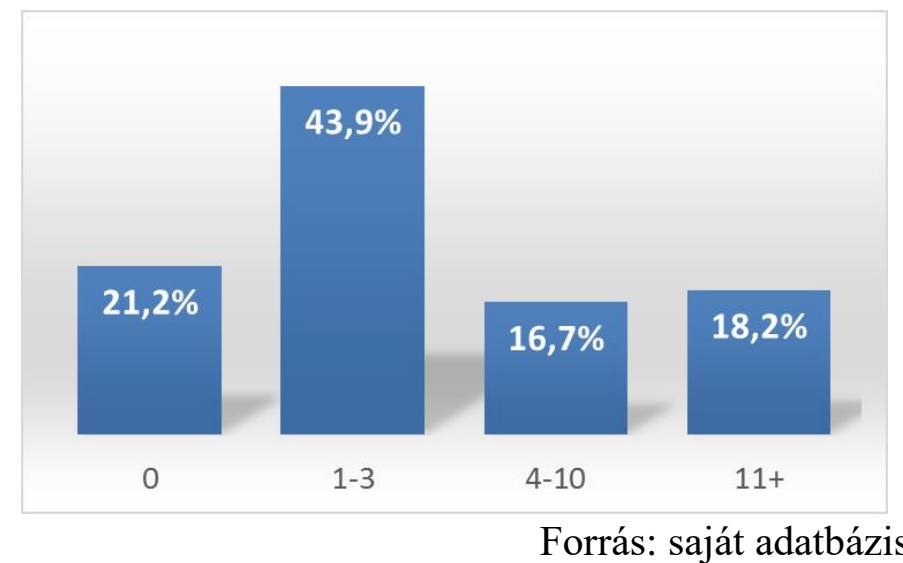

A munkavállalók nemzetiségét tekintve elmondható, hogy a startupok 90\%-a csak magyarokat alkalmazott, míg 10\% külföldieket is. Ez azt mutatja, hogy a magyar startupok főként cégen kívüli szereplők - mint például a tanácsadók vagy a mentorok - segítségével kívánják erősíteni nemzetközi kapcsolataikat.

Most vizsgáljuk meg a startupok jövőbeli foglalkoztatási terveit. A megkérdezett cégek 23\%-a a megkérdezés pillanatában is felvett volna már új alkalmazottakat, 69\%-uk maximum 6 hónappal később, 88\%-uk a következő egy éven belül. Ezek a számok a startup szektor munkahelytermetési potenciálját indikálják, tehát támogatják a 2 bropozíciót - „A magyar startupok munkahelyteremtési potenciálja jelentös".

9. ábra: Mikor terveznek a startupok új munkavállalókat felvenni?

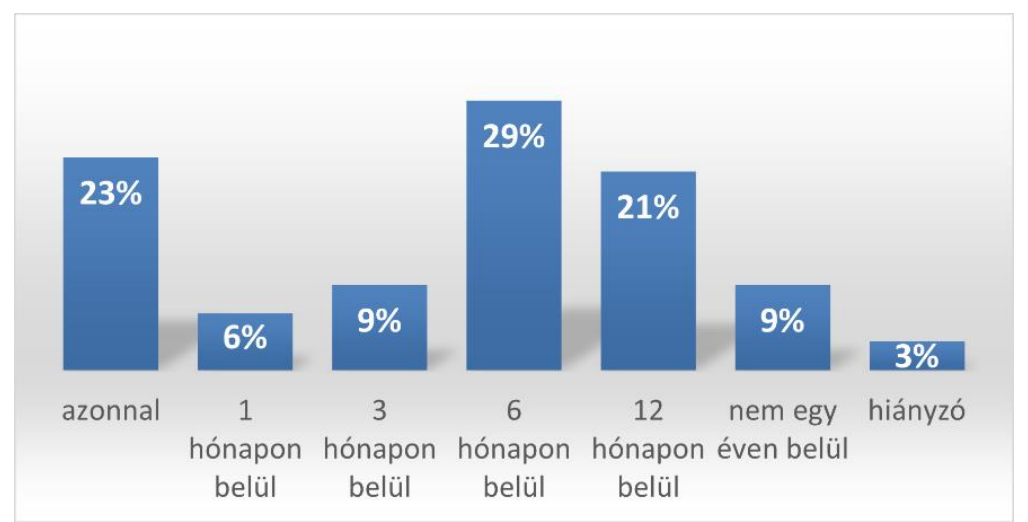

Forrás: saját adatbázis 


\subsubsection{Finanszírozás}

A tanulmányban a startupok következő fejlettségi fázisai lettek megkülönböztetve:

- Ötlet/koncepció fázisa

- Béta-verzió/prototípus és termékvalidáció

- Korai bevételgenerálás

- Növekedés/növekvő bevétel generálása

- Érett cég

Az inkubátorházak és az akcelerátorok a startupokat a kezdeti fázistól támogatják, onnantól, amikor még csak egy üzleti ötlet létezik, prototípus még nem. A kockázati tőkebefektetők azonban érettebb fázisú startupokat preferálnak, lehetőség szerint a „korai bevételgenerálás” szakaszában lévőket, amelyet aztán a „terjeszkedés/növekvő bevétel generálása” fázis követhet; illetve azokat, amelyek béta verzióval vagy prototípussal rendelkeznek csak, de a termék már validált.

Aman és Lovas (2015) arra is rávilágítanak, hogy a kockázati tőkések tipikusan olyan kis- és középvállalkozásokat finanszíroznak, amelyek magas növekedési potenciált rejtenek magukban. Olyan cégeket részesítenek előnyben, amelyek már generálnak bevételt, és amelyek már növekedési periódusban vannak. Lovas és Riz (2016) arra mutattak rá, hogy az inkubátorok, az akcelerátorok és az üzleti angyalok ennél korábbi szakaszban is hajlandóak támogatni a startupokat, de ők is magas növekedési potenciállal rendelkező cégeket keresnek. Mindössze egy kifejlesztett terméket/szolgáltatást várnak el, és abban támogatják a vállalkozásokat, hogy piacra vigyék terméküket.

A kérdőívben résztvevő startupok 52\%-a már generált bevételt, és potenciális befektetési célpontjai a kockázati tőkebefektetőknek. Ezen kívül a startupok 35\%-a rendelkezik béta verzióval/prototípussal, amellyel támogatást és finanszírozást kaphatnak akcelerátoroktól vagy inkubátorházaktól. 
10. ábra: A magyar startupok érettsége

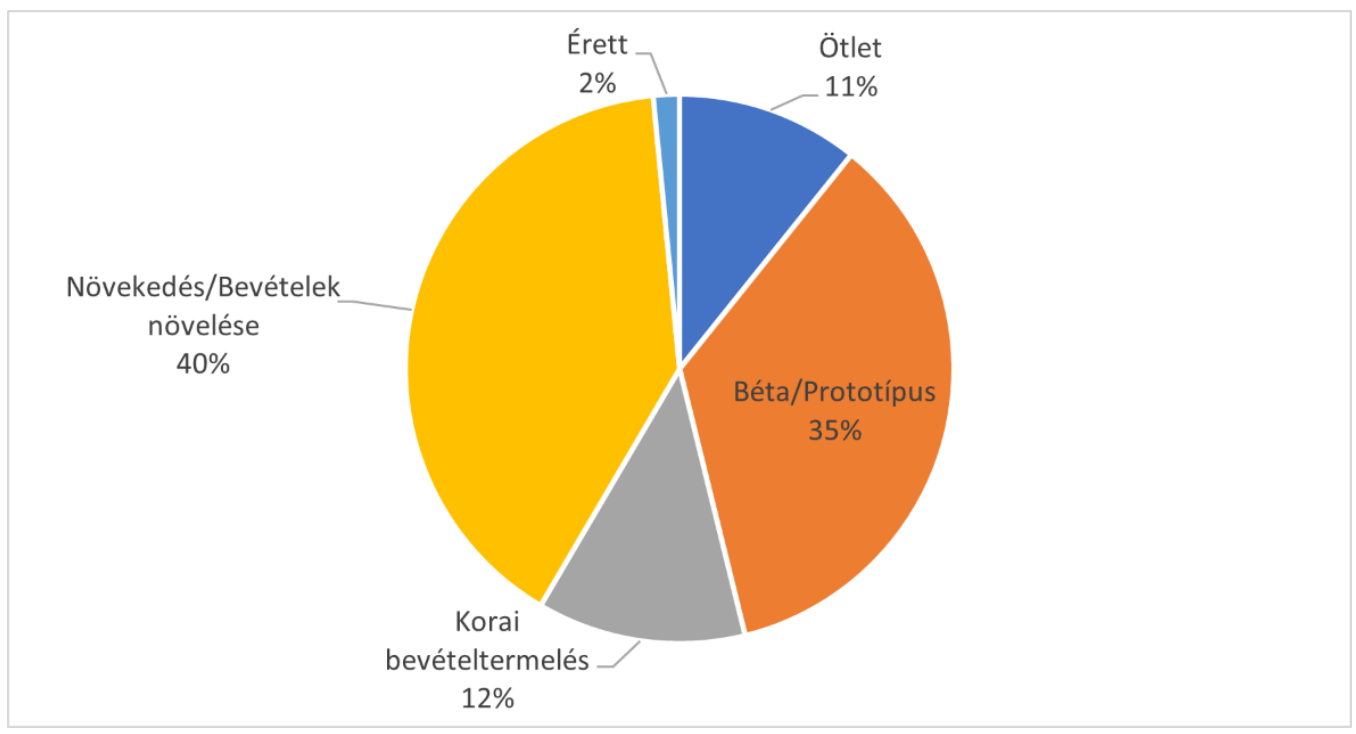

Forrás: saját adatbázis

A befektetésért cserébe kért részesedés nagyságát illetően elmondható, hogy a legtöbb befektető esetében ez 0 -50\% közé esik. Levonhatjuk a következtetést, hogy a befektetők általában a többségi tulajdonrészt az eredeti tulajdonosok kezében hagyják, és csak kisebbségi részesedésük lesz a cégben. Az akcelerátorok általánosságban kisebb részesedést kérnek, mint a kockázati tőkealapok. Az említett érintettek csak kis része említette azt, hogy alkalmanként többségi tulajdonrészt kérne el.

Láthattuk, hogy a startup vállalkozók nagyrészt középkorúak, így lehetséges, hogy felhalmoztak már megtakarításokat. 17\%-uk teljes munkaidőben dolgozik, 75\%-uk plusz egy vagy több startup mellett kötelezte el magát. A finanszírozást tekintik a legnagyobb kihívásnak a hosszútávú növekedési stratégia kivitelezésében. Ezen belül a finanszírozókhoz történő kapcsolódás, valamint a megfelelő információ megszerzése bizonyulnak a legnehezebbek. A kivitelezés időtartama ezen felül megnehezíti a dolgukat. A vállalkozók 86\%-a saját megtakarításából kezdte üzletét, és csak 27\%-uk kapott tőkét családtagoktól vagy barátoktól. A startup cégek csak 24\%-a emelt tőkét kockázati tőkebefektetők segítségével, emellett 9\%-uk említette az üzleti angyalokat. A 2c propozíció - A magyar startupok fó finanszírozási forrása a kockázati töke bevonása - tehát részben bizonyul támogatottnak, hiszen a kockázati tőke valóban nagy szerepet játszik a finanszírozásban, ám nem ez a legfontosabb forrás. A banki kölcsön nem jelentős finanszírozási forrás, a válaszadók csak egy kis része (3\%-a) számolt be arról, hogy bankoktól kapott finanszírozást. Ez 
nem meglepő, hiszen ezek a cégek általában még nem elég érettek ahhoz, hogy kereskedelmi bankoktól kölcsönt kapjanak.

11. ábra: A startupok legfontosabb kezdeti forrásai

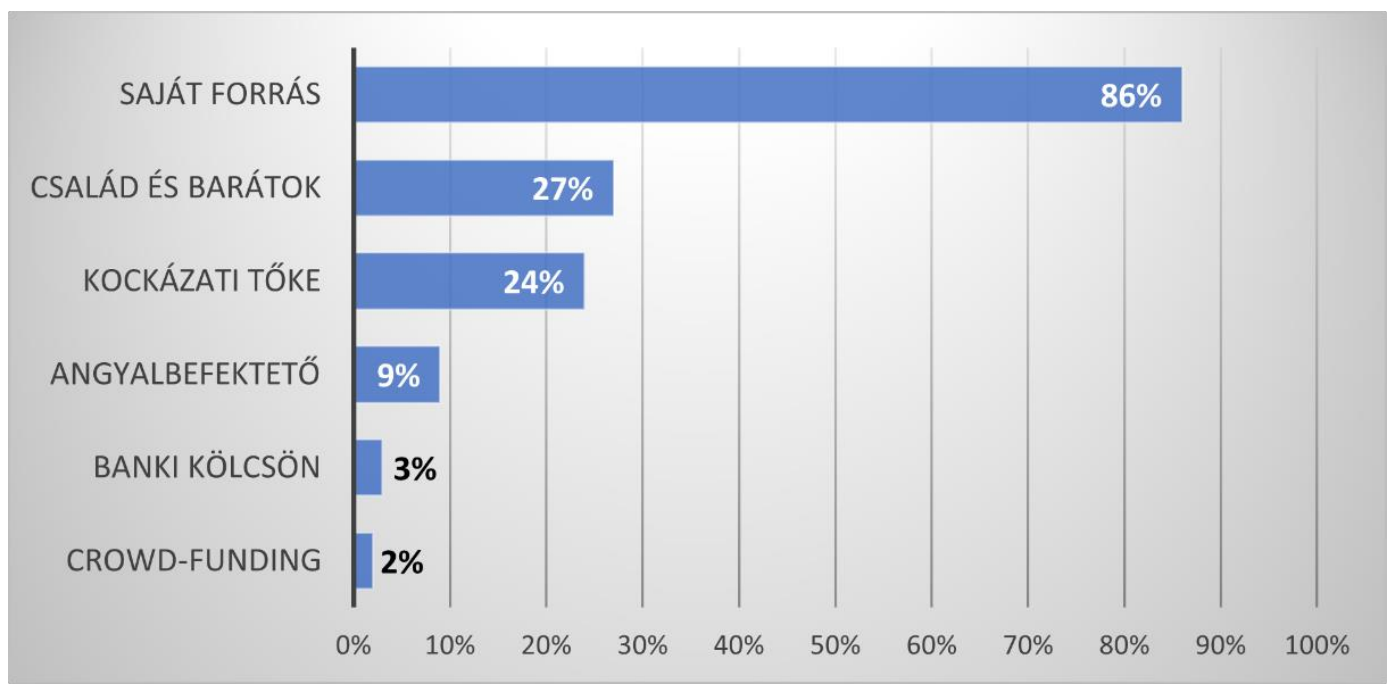

Forrás: saját adatbázis

Ha a többi V4-országban tekintjük a startupok finanszírozási forrásait, hasonló mintát láthatunk. Az alapító saját forrásai állnak első helyen (Lengyelországban a startupok 79\%-a, Csehországban 78\%-a, Szlovákiában 87\%-a használja ezt); a kockázati tőkebevonás aránya is hasonló (22\% Lengyelországban, 12,8\% Csehországban, 24\% Szlovákiában); ám nagy az állami támogatás szerepe is: $24 \%$ Lengyelországban, 12\% Csehországban és 21\% Szlovákiában (Staszkiewicz \& Havliková, 2016; Dzurovčinová, 2016; Skala \& Kruczkowska, 2016). Azonban meg kell jegyezni, hogy Magyarországon az állami támogatás gyakran állami kockázati tőkebefektetés formájában valósul meg. Ez a jelenség a későbbi fejezetekben további elemzés tárgya lesz. A korábban tárgyalt tényezőket összegezve megállapítható, hogy számos hasonlóság mutatkozik a magyar startup ökoszisztéma és a V4 országok startup ökoszisztémája között: a startupok fövárosi koncentrációja, a sikertelen startupban már közremüködő startupperek százalékos aránya, a startupok külföldi piacokra való belépési szándéka, a startup finanszírozási forrásai és a startupok mérete az alkalmazottak számát tekintve, tehát a $2 d$ propozíció - „A hazai startup-ökoszisztéma a legfontosabb tulajdonságokat tekintve hasonló a többi V4-es ország startup ökoszisztémájához" - támogatásra talált.

Minden startup számára az első évek feladata, hogy kifejlessze termékét vagy szolgáltatását, ami folyamatosan új pénzügyi forrásokat igényel. A vizsgált startupok 
az érettség különböző fázisaiban voltak; ebből következően különböző finanszírozók érdeklődését kelthetik fel. A 12. ábra azt mutatja, hogy a startupperek 30\%-a próbál kockázati tőkebefektetőket bevonni üzletébe. Az üzleti angyalok érdeklődését 9\%-uk kelti fel, és csak $6 \%$ tervez családtaghoz vagy barátokhoz fordulni további forrásért.

12. ábra: Hova fordulnak a startupperek új pénzügyi forrásokért?

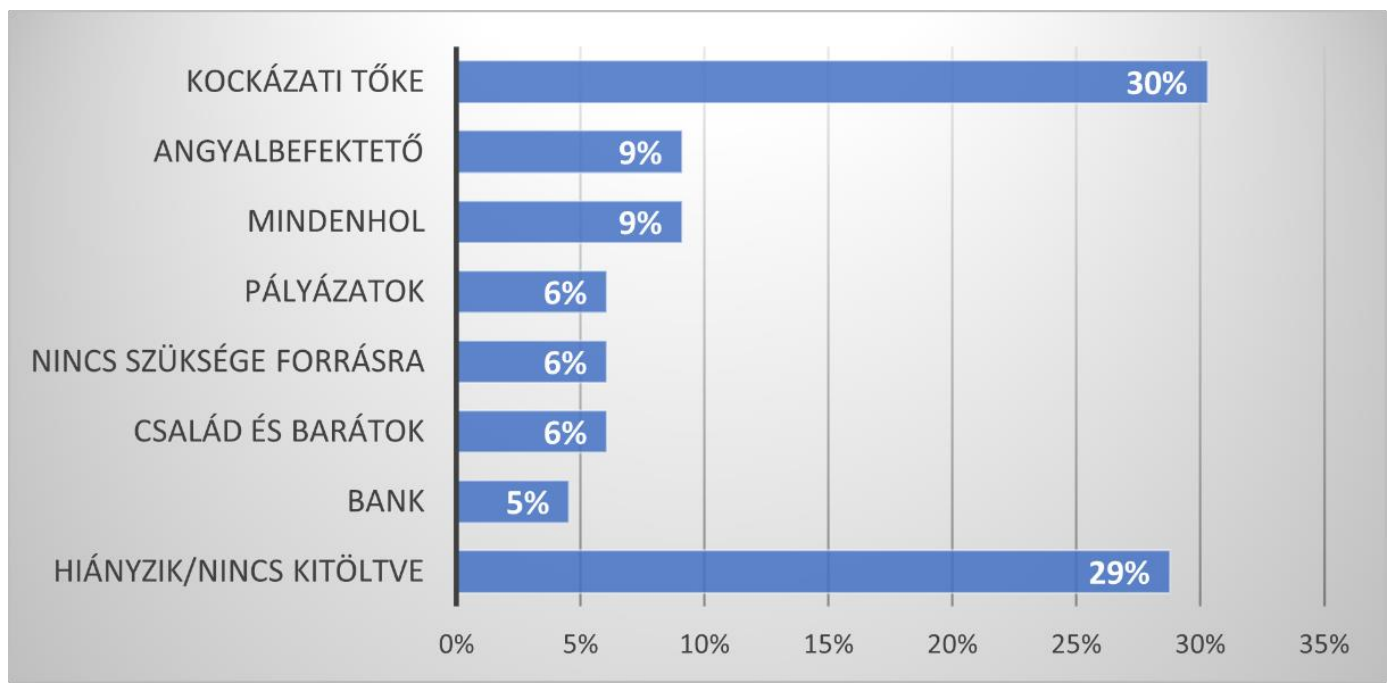

Forrás: saját adatbázis

A közösségi finanszírozás eddig nem kapott nagy szerepet országunkban, csak a startupperek 2\%-a használta fel. Liu és Wang (2018) a crowd-funding előnyei között emelik ki, hogy ennek köszönhetően a cégek pontosabb piaci visszajelzést kapnak az új termékükről, mint azok, amelyeket kockázati tőkealapok finanszíroznak. Ennek a vizsgálatnak az eredménye összhangban van Dong és Men (2014) megállapításaival, akik azt hangsúlyozták, hogy a külső finanszírozási források hozzáférhetősége véges a fiatal, kicsi és nem gyártó cégek számára. Ezek a jellemzők a magyar startupok esetében is igazak.

\subsection{A startup ökoszisztéma megítélése}

Az alábbi alfejezetben megvizsgáljuk, hogy a válaszadó ökoszisztéma szereplők milyen fontosságot társítanak az egyes ökoszisztéma-jellemzőkhöz, illetve azokat mennyire tartják erősnek a hazai ökoszisztémában, illetve, hogy van-e eltérés az ökoszisztéma szereplők véleményei között (6-9. kutatási kérdések). 


\subsubsection{A startup ökoszisztéma jellemzöinek fontossága}

A 6. kérdés megválaszolásához tekintsük most meg, milyen fontosságot társítanak az ökoszisztéma tagjai a különböző tényezőkhöz (lásd: alábbi táblázat).

5. táblázat: A startup ökoszisztéma jellemzőinek fontossága

\begin{tabular}{|c|c|c|c|c|c|c|c|}
\hline \multirow[t]{2}{*}{ Jellemzők } & \multicolumn{3}{|c|}{$\begin{array}{l}\text { Központi tendencia } \\
\text { méröszámai }\end{array}$} & \multirow[b]{2}{*}{ Szórás } & \multicolumn{2}{|c|}{$\begin{array}{c}\text { Az átlag 95\%- } \\
\text { os konfidencia } \\
\text { intervalluma }\end{array}$} & \multirow{2}{*}{$\begin{array}{c}\text { Nagyon } \\
\text { fontos (4) } \\
\text { és abszolú } \\
\text { létfontossá } \\
\text { gú (5) } \\
\text { válaszok } \\
\text { gyakoriság } \\
\text { a }\end{array}$} \\
\hline & Átlag & Medián & Módusz & & Alsó & Felső & \\
\hline \multicolumn{8}{|l|}{ 1. csoport } \\
\hline $\begin{array}{l}\text { Az ökoszisztéma tagjainak } \\
\text { együttműködési hajlandósága }\end{array}$ & 4,42 & 5 & 5 & 0,855 & 4,250 & 4,590 & 87 \\
\hline Nemzetközi kapcsolatok & 4,39 & 5 & 5 & 0,852 & 4,221 & 4,559 & 82 \\
\hline Fejlett vállalkozói kultúra & 4,29 & 5 & 5 & 0,957 & 4,100 & 4,480 & 83 \\
\hline Finanszírozáshoz való hozzáférés & 4,25 & 4,5 & 5 & 0,892 & 4,073 & 4,427 & 79 \\
\hline $\begin{array}{l}\text { Megfelelöen képzett } \\
\text { munkaerőhöz való hozzáférés }\end{array}$ & 4,25 & 4,5 & 5 & 0,947 & 4,062 & 4,438 & 83 \\
\hline \multicolumn{8}{|l|}{ 2. csoport } \\
\hline $\begin{array}{l}\text { Sikeres startupperek jelenléte, } \\
\text { mint mentorok, ill. üzleti } \\
\text { angyalok }\end{array}$ & 4,22 & 5 & 5 & 0,970 & 4,028 & 4,412 & 76 \\
\hline $\begin{array}{l}\text { Magas minőségü ötletek vagy } \\
\text { projektek száma }\end{array}$ & 4,19 & 4 & 5 & 0,907 & 4,010 & 4,370 & 79 \\
\hline $\begin{array}{l}\text { Kedvező adózási környezet } \\
\text { vállalkozóknak }\end{array}$ & 4,18 & 4 & 5 & 0,968 & 3,988 & 4,372 & 80 \\
\hline $\begin{array}{l}\text { Kedvező elvárt adminisztrációs } \\
\text { mennyiség vállalkozóknak }\end{array}$ & 4,14 & 4 & 5 & 0,975 & 3,947 & 4,333 & 74 \\
\hline \multicolumn{8}{|l|}{ 3. csoport } \\
\hline $\begin{array}{l}\text { Mentorokhoz, tanácsadókhoz, } \\
\text { coachokhoz való hozzáférés }\end{array}$ & 3,93 & 4 & 4 & 1,066 & 3,718 & 4,142 & 73 \\
\hline $\begin{array}{l}\text { Hozzáférés vállalkozói } \\
\text { oktatáshoz }\end{array}$ & 3,88 & 4 & 5 & 1,225 & 3,637 & 4,123 & 67 \\
\hline $\begin{array}{l}\text { Közösségi események } \\
\text { (meetupok, networking) }\end{array}$ & 3,72 & 4 & 3 & 0,944 & 3,533 & 3,907 & 56 \\
\hline Technológiaátadás & 3,59 & 4 & 4 & 1,065 & 3,379 & 3,801 & 55 \\
\hline \multicolumn{8}{|l|}{ 4. csoport } \\
\hline Co-working irodák jelenléte & 2,97 & 3 & 3 & 1,087 & 2,754 & 3,186 & 29 \\
\hline Startup versenyek & 2,96 & 3 & 3 & 1,205 & 2,721 & 3,199 & 35 \\
\hline
\end{tabular}

A jellemzők fontossági megítélési alapján 4 csoportot azonosítottunk a központi tendencia értékei és a (4) és (5) fontossági besorolás gyakoriságát tekintve.

1. Az 1. csoportba azok a jellemzők kerültek, amiket a startup ökoszisztéma tagjainak a legfontosabbnak ítéltek: együttműködési hajlandósága, a nemzetközi kapcsolatok, a fejlett vállalkozói kultúra, a finanszírozáshoz való 
hozzáférés, valamint a hozzáférés a megfelelően képzett munkaeröhöz. A csoport összes elemének 5 a mediánja és módusza, és 4.25-tel egyenlő vagy annál nagyobb az átlaga. A 3 a propozíció - „A magyar startup ökoszisztéma tagjai a finanszirozáshoz való hozzáférést tartják a startup ökoszisztéma legfontosabb elemének" - részben támogatott, mivel a finanszírozáshoz való hozzáférés az egyik legfontosabb jellemvonás, azonban két másik tényező is megelőzi.

2. A 2. csoportba a következők tartoznak: sikeres vállalkozók jelenléte mentorokként vagy angyalbefektetőkként; a magas minőségü ötletek vagy projektek száma; a kedvező adókörnyezet a vállalkozók számára; és a kedvező elvárt adminisztráció mennyisége a vállalkozók számára elemek tartoznak. E csoport tagjainak a mediánja 4, módusza 5, és az átlaga 4 fölött van.

3. A 3. csoport elemei a mentorokhoz, tanácsadókhoz, coachokhoz való hozzáférés; a hozzáférés vállalkozói oktatáshoz; a közösségi események (meetupok, networking); és a technológia átadás. Ezen csoport tagjainak az átlaga mind 3 és 4 között van.

4. A 4. csoport, amibe a legalacsonyabb fontossággal bíró jellemző került: a coworking irodák és a startup versenyek jelenléte. Ezen tételek mediánja és módusza 3, átlaga $\sim 3$.

A finanszírozáshoz való hozzáférést a legfontosabbak közé sorolték a résztvevők, míg a startup versenyeket a legkevésbé fontosak közé. Ez azt mutathatja, hogy a startupperek befektetőkkel való találkozása föként nem startup versenyek során történik meg, hanem alternatív, proaktívabb módokon.

Ha a 7. kutatási kérdés megválaszolásának érdekében megnézzük az ökoszisztéma-tagok alcsoportjai közti szignifikáns különbségeket kereső tesztet (6. táblázat), láthatjuk, hogy az egyirányú ANOVA szignifikáns különbségeket talált a co-working irodák megléte és a kedvező vállalkozói adókörnyezet tekintetében, tehát a 3 b propozíció - „Nincsenek jelentős véleménybeli különbségek az ökoszisztéma-tagok alcsoportjai között a startup ökoszisztéma tényezöinek fontosságát illetöen” - nem talált támogatásra. A co-working terek jelentőségét sokkal nagyobbra értékelték az ilyen irodák képviselői, mint a befektetők és a startupperek. Bármilyen ökoszisztémában természetes, hogy egy adott terület megbízottja túlbecsüli saját fontosságát, de az, hogy maguk a startupperek átlag alattinak értékelték a co-working irodák 
fontosságát, egészen meglepő. A kedvező vállalkozói adókörnyezet jelentőségét illetően elmondhatjuk, hogy ezt a tényezőt a startupperek jóval fontosabbnak látják, mint az inkubátorok és az akcelerátorok. Ez annak lehet köszönhető, hogy a startupperek nap, mint nap saját vállukon érzik a vállalkozás menedzselésének pénzügyi terheit, míg az ökoszisztéma inkább segítségnyújtásra és coachingra összpontosító tagjai sokkal inkább a javításra szoruló belső tényezőkre fókuszálnak, mint a külsőkre.

6. táblázat: Az alminták átlagának összehasonlítása (ANOVA és Hochberg $\alpha<5 \%$ )

\begin{tabular}{|c|c|c|c|c|c|c|}
\hline & $\begin{array}{l}\text { Egyirányú } \\
\text { ANOVA } \\
\text { Szig. }\end{array}$ & Alcsoport & $\begin{array}{l}\text { Alminta } \\
\text { átlaga }\end{array}$ & Alcsoport & $\begin{array}{l}\text { Alminta } \\
\text { átlaga }\end{array}$ & $\begin{array}{l}\text { Hochberg } \\
\text { Szig. }\end{array}$ \\
\hline \multirow{2}{*}{$\begin{array}{l}\text { Közösségi terek } \\
\text { fontossága }\end{array}$} & \multirow{2}{*}{0,018} & befektetők & 2,636 & $\begin{array}{l}\text { co-working } \\
\text { iroda }\end{array}$ & \multirow{2}{*}{4,667} &, 035 \\
\hline & & startupok & 2,828 & $\begin{array}{l}\text { co-working } \\
\text { iroda }\end{array}$ & &, 036 \\
\hline $\begin{array}{l}\text { Kedvező } \\
\text { vállalkozói } \\
\text { adókörnyezet } \\
\text { fontossága }\end{array}$ & 0,005 & startupok & 4,414 & $\begin{array}{l}\text { inkubátorok, } \\
\text { akcelerátorok }\end{array}$ & 3,583 & ,003 \\
\hline $\begin{array}{l}\text { A magyar } \\
\text { ökoszisztéma } \\
\text { értékelése a } \\
\text { finanszírozáshoz } \\
\text { való hozzáférés } \\
\text { szempontjából }\end{array}$ & 0,011 & startupok & 2,586 & $\begin{array}{l}\text { inkubátorok, } \\
\text { akcelerátorok }\end{array}$ & 3,333 &, 046 \\
\hline $\begin{array}{l}\text { A magyar } \\
\text { ökoszisztéma } \\
\text { értékelése a } \\
\text { képzett } \\
\text { munkaerőhöz } \\
\text { való hozzáférés } \\
\text { szempontjából }\end{array}$ & 0,030 & befektetők & 3,273 & vállalatok & 1,500 &, 030 \\
\hline
\end{tabular}

Forrás: saját adatbázis

\subsubsection{A startup ökoszisztéma jellemzöinek megítélése}

Folytassuk azzal, hogy elemezzük, miként értékelik a magyar ökoszisztéma egyes jellemvonásait az ökoszisztéma tagjai (8. kérdés). A 7. táblázat alapján a következő tulajdonságcsoportokat lehet megkülönböztetni a központi tendencia mértékeket útmutatóként használva:

7. táblázat: A startup ökoszisztéma jellemzőinek minőségi megítélése

\begin{tabular}{|c|c|c|c|c|c|c|c|}
\hline \multirow[t]{2}{*}{ Jellemzők } & \multicolumn{3}{|c|}{$\begin{array}{l}\text { Központi tendencia } \\
\text { mérőszámai }\end{array}$} & \multicolumn{3}{|c|}{$\begin{array}{c}\text { Az átlag 95\%-is } \\
\text { konfidencia } \\
\text { intervalluma }\end{array}$} & \multirow{2}{*}{$\begin{array}{l}\text { Jó (4) és } \\
\text { nagyon jó } \\
\text { (5) válaszok } \\
\text { gyakorisága }\end{array}$} \\
\hline & Átlag & Medián & Módusz & Szórás & Alsó & Felső & \\
\hline
\end{tabular}




\begin{tabular}{|c|c|c|c|c|c|c|c|}
\hline \multirow[t]{2}{*}{ Jellemzők } & \multicolumn{3}{|c|}{$\begin{array}{l}\text { Központi tendencia } \\
\text { mérőszámai }\end{array}$} & \multirow[b]{2}{*}{ Szórás } & \multicolumn{2}{|c|}{$\begin{array}{c}\text { Az átlag 95\%-is } \\
\text { konfidencia } \\
\text { intervalluma }\end{array}$} & \multirow{2}{*}{$\begin{array}{l}\text { Jó (4) és } \\
\text { nagyon jó } \\
\text { (5) válaszok } \\
\text { gyakorisága }\end{array}$} \\
\hline & Átlag & Medián & Módusz & & Alsó & Felső & \\
\hline \multicolumn{8}{|l|}{ 1. csoport } \\
\hline $\begin{array}{l}\text { Közösségi események } \\
\text { (meetupok, networking) }\end{array}$ & 3,71 & 4 & 4 & 0,820 & 3,547 & 3,873 & 61 \\
\hline \multicolumn{8}{|l|}{ 2. csoport } \\
\hline Co-working irodák jelenléte & 3,33 & 3 & 3 & 0,995 & 3,132 & 3,528 & 38 \\
\hline Startup versenyek & 3,24 & 3 & 3 & 0,911 & 3,059 & 3,421 & 40 \\
\hline $\begin{array}{l}\text { Magas minőségü ötletek } \\
\text { vagy projektek száma }\end{array}$ & 3,08 & 3 & 3 & 1,079 & 2,866 & 3,294 & 32 \\
\hline $\begin{array}{l}\text { Mentorokhoz, } \\
\text { tanácsadókhoz, coachokhoz } \\
\text { való hozzáférés }\end{array}$ & 3,03 & 3 & 3 & 0,893 & 2,853 & 3,207 & 27 \\
\hline \multicolumn{8}{|l|}{ 3. csoport } \\
\hline $\begin{array}{l}\text { Sikeres startupperek } \\
\text { jelenléte, mint mentorok, ill. } \\
\text { üzleti angyalok }\end{array}$ & 2,88 & 3 & 3 & 0,967 & 2,688 & 3,072 & 29 \\
\hline $\begin{array}{l}\text { Finanszírozáshoz való } \\
\text { hozzáférés }\end{array}$ & 2,87 & 3 & 3 & 1,116 & 2,649 & 3,091 & 30 \\
\hline $\begin{array}{l}\text { Az ökoszisztéma tagjainak } \\
\text { együttmüködési hajlandósága }\end{array}$ & 2,81 & 3 & 3 & 0,982 & 2,615 & 3,005 & 22 \\
\hline \multicolumn{8}{|l|}{ 4. csoport } \\
\hline Technológiaátadás & 2,68 & 3 & 3 & 0,898 & 2,502 & 2,858 & 11 \\
\hline $\begin{array}{l}\text { Megfelelően képzett } \\
\text { munkaerőhöz való } \\
\text { hozzáférés }\end{array}$ & 2,67 & 3 & 3 & 1,035 & 2,465 & 2,875 & 19 \\
\hline Nemzetközi kapcsolatok & 2,61 & 2 & 2 & 0,973 & 2,417 & 2,803 & 18 \\
\hline \multicolumn{8}{|l|}{ 5. csoport } \\
\hline $\begin{array}{l}\text { Hozzáférés vállalkozói } \\
\text { oktatáshoz }\end{array}$ & 2,22 & 2 & 2 & 1,021 & 2,017 & 2,423 & 11 \\
\hline $\begin{array}{l}\text { Kedvező adózási környezet } \\
\text { vállalkozóknak }\end{array}$ & 2,11 & 2 & 1 & 1,024 & 1,907 & 2,313 & 11 \\
\hline Fejlett vállalkozói kultúra & 2,09 & 2 & 1 & 1,083 & 1,875 & 2,305 & 11 \\
\hline $\begin{array}{l}\text { Kedvező elvárt } \\
\text { adminisztrációs mennyiség } \\
\text { vállalkozóknak }\end{array}$ & 1,96 & 2 & 1 & 0,994 & 1,763 & 2,157 & 8 \\
\hline $\begin{array}{l}\text { Értékelje a hazai startup } \\
\text { ökoszisztémát }\end{array}$ & 2,91 & 3 & 3 & 0,900 & 2,731 & 3,089 & 22 \\
\hline
\end{tabular}

Forrás: saját adatbázis

A legjobb értékelést a közösségi események (meetupok, networking) jellemző kapta (mediánja és módusza is 4 , átlaga 3,71), mely a második legmagasabbra értékelt jellemzőtől mind a központi tendencia mértékeiben, mind a (4) és (5) válaszok gyakoriságában jelentősen eltér. 
A második legjobb értékelésbe azon jellemzők kerültek, melyek mediánja és módusza is 3, és az átlaga 3-3,5 közötti. Ide tartoznak a co-working irodák megléte; a startup versenyek; a magas minöségü ötletek vagy projektek száma; és a mentorokhoz, tanácsadókhoz, coachokhoz való hozzáférés. Érdekes, hogy a coworking irodák és a startup versenyek voltak, amiket a legkevésbé tartottak fontosnak a válaszadók, azonban a kiemelt minőségü jellemzőre értékelték magyar ökoszisztéma szereplői. Annak ellenére, hogy a lista elején szerepel, csak az „elfogadható” a minőségi értékelése.

A harmadik csoportban szerepelnek azok a jellemzők, melyek mediánja és módusza is 3 , az átlaguk 2,8 és 2,9 között van. Ide kerültek a következő jellemzők: $a$ sikeres startupper vállalkozók jelenléte mentorokként vagy angyalbefektetökként; a finanszírozáshoz való hozzáférés; valamit a startup ökoszisztéma együttmüködési hajlandósága. A finanszírozáshoz való hozzáférés az egyik legfontosabb jellemzője az ökoszisztémának, az minőségének az értékelése enyhén átlag alatti, így a $4 a$ propozíció - „A magyar startup ökoszisztéma tagjai a finanszírozáshoz való hozzáférést tartják a magyar startup ökoszisztéma legerösebb tulajdonságának” nem talált támogatásra. Az utóbbi évek állami kezdeményezései (pl. Jeremie program, vagy a Hiventures kockázati tőkealap-kezelő megalapítása) ellenére az ökoszisztéma tagjai még mindig úgy érzik, hogy a finanszírozáshoz való hozzáférés lehetősége enyhén átlag alatti hazánkban. Lehetséges, hogy más tényezők is akadályozzák a startuppereket abban, hogy kihasználják a piac hatalmas tőkeellátottságát, mint például, ha nem rendelkeznek az ötletük prezentálásához és a befektetők meggyőzéséhez szükséges képességekkel.

A negyedik csoport tagjai a technológia-átadás, a megfelelöen képzett munkaerőhöz való hozzáférés, valamint a nemzetközi kapcsolatok. Ezen jellemzők átlaga és módusza 2 és 3, átlaga 2,6 és 2,7 között.

Az ötödik csoport tényezői a következők: vállalkozói oktatáshoz való hozzáférés, kedvezö adózási környezet vállalkozóknak, fejlett vállalkozói kultúra (lehetöség újrakezdésre sikertelen startup után); és kedvezö elvárt adminisztrációmennyiség vállalkozóknak. A csoport tagjainak mediánja és módusza 1 és 2 , míg átlaguk 2,5 alatti.

Ha a tényezők megítélésében jelen lévő szignifikáns különbségeket tekintjük az ökoszisztéma szereplői között (6. kérdés) a 6. táblázatban, láthatjuk, hogy van két tényező, amelyeknél találhatunk ilyen különbségeket, tehát a $4 b$ propozíció - 
„,Nincsenek jelentős véleménybeli különbségek az ökoszisztéma tagok alcsoportjai között a magyar startup ökoszisztéma tényezőinek értékelését illetően” - nem talált támogatásra. Az első a finanszírozáshoz való hozzáférés értékelése a magyar ökoszisztémában. A startupperek ezt sokkal alacsonyabbra értékelték, mint az akcelerátorok és inkubátorok, mivel az első körös befektetés biztosítóinak nem kell átélniük azokat a nehézségeket, amelyeket a startupperek átélnek a finanszírozás megszerzése folyamán. A második jellemző a megfelelően képzett munkaerőhöz való hozzáférés értékelése. A vállalatok ezt a befektetőknél jóval alacsonyabbra értékelték. A vállalatoknak érdekük füződik a startupperek támogatásához az iparágukban történő innováció érdekében, és azt remélik, hogy felvásárolhatják ezeket a startupokat, amikor azok érettsége elér egy elégséges szintet. Igen valószínü, hogy a vállalatok ezt az értékelést a saját szubjektív élményeikre alapozzák, amelyeket a képzett munkaerő keresése és felvétele során szereztek, és ezeket vetítik ki a startupokra. A befektetők azonban közelebbi kapcsolatot ápolnak a startupokkal, és valószínűleg reálisabban látják a helyzetet.

Itt érdemes ránézni a többi V4 ország startup ökoszisztémájának erősségeire és gyengeségeire Beauchamp és Skala (2017) kutatása alapján. Csehország esetében állapították meg a legmagasabb $\mathrm{K}+\mathrm{F}$ aktivitást, a Globális Innovációs Index alapján magas fokú globális technológiai outputot, és a szabadalmak bejegyzésében is a legaktívabb volt. A gyengeségek közé tartozik, hogy kevés startup eseményt szerveznek, alacsony az elérhető kockázati tőkebefektetés, és kicsi a közszféra finanszírozásának mértéke. Érdemes megjegyezni, hogy a kutatásunkban a magyar ökoszisztéma tagok a startup eseményeket tartották a legerősebb, de az egyik legkisebb fontosságú tényezőnek. Beauchamp és Skala (2017) kimutatták, hogy a lengyel ökoszisztéma erősségei részben az ország méretén, számottevő gazdasági és humán tőkéjén, magas nemzeti fogyasztásán nyugszanak - mindezen faktorok miatt ennek az országnak a startupjai függenek legkevésbé az exporttevékenységtől. Emellett ez az egyetlen V4 ország, ahol 1-nél több fő startup központ („hub”) található. A gyengeségei közé tartozik az alacsony $\mathrm{K}+\mathrm{F}$ költés, és a legalacsonyabb Globális Innovációs Index szerinti helyezés. Végezetül Szlovákiában találták a legmagasabb hatékonyságú munkaerőt a magas export aktivitás és az erős ekereskedelmi piac mellett, emellett a közösségi finanszírozási piaca a V4 országok között a legnépszerübb volt. A legnagyobb gyengesége azonban, hogy a munkanélküliség itt a legmagasabb a V4-en belül. Magyarország erőssége, hogy itt a 
leggyakoribb a munkaerőfelvétel, igen aktívak a kockázati tőkebefektetők, a Globális Innovációs Index alapján magas szintű a globális technológiai kibocsátás, illetve a mobiltelefon penetráció mértéke itt a legmagasabb. Lengyelországhoz képest a magyar startupoknak jobban kell nemzetközi piacokra fókuszálniuk, és kérdőívünk alapján a vállalkozói adókörnyezet, adminisztrációs terhek, és a vállalkozói oktatási lehetőségek is javításra szorulnak.

\section{5 Összefoglalás}

Konklúzióként elmondhatjuk, hogy a magyar startupperek általában középkorú, budapesti férfiak, akiknek vállalkozói vagy multinacionális cégben szerzett tapasztalata van. Majdnem a felük már részt vett sikertelen startupban. Csak kis százalékuk egyetemi hallgató. Összességében legalább BA-szintü üzleti (marketing, pénzügyi vagy közgazdaságtani) képesítésük van. A fiatalabb generáció esetében a fő motiváció a startup indításra a nagyobb szabadság és kihívás igénye. Az idősebb válaszadók motivációja egyfajta kiégésből származik. Sokuk ellenzi a multinacionális cégek kultúráját. A középkorú csoportok általánosságban „újra szeretnék teremteni” magukat és megvalósítani innovatív ötletüket. A startuppereknek a legnagyobb külső segítségre új piacokra való belépés, termékfejlesztés és értékesítés területén van szükségük. A startupok jelentős munkahelyteremtési potenciállal bírnak, és majdnem minden válaszadó megjelölte, hogy egy éven belül új munkavállalókat tervez felvenni. A fő finanszírozási forrás kezdetben maga a vállalkozó, a család vagy a barátok tőkéje, illetve a kockázati tőke; ám a startupok később föként kockázati tőke bevonásával szeretnének további finanszírozásra szert tenni.

A fejezet azt is vizsgálta, hogy a startup ökoszisztéma tagjai - a startupperek, a kockázati tőkebefektetők, az inkubátorok és az akcelerátorok, a vállalatok és a coworking irodák - mit gondolnak a startup ökoszisztéma jellemzőiröl, és hogyan értékelik a magyar ökoszisztémát ezen jellemvonások mentén. Az ökoszisztéma tagjai közötti kooperációt, a nemzetközi kapcsolatokat, valamint a bukott startup utáni újrakezdés lehetőségét tartották a leglényegesebbnek. A co-working irodák és startup versenyek megléte volt a legkevésbé fontos számukra. Azt is érzik, hogy a

co-working irodák és a startup versenyek túlreprezentáltak a magyar ökoszisztémában az érzékelt fontosságukhoz képest. Szerintük a közösségi események (mint például a találkozók é a networking) a legerősebb tényezők az 
itthoni ökoszisztémában. Azonban a vállalkozói oktatáshoz való hozzáférés, a kedvező vállalkozói adókörnyezet, a fejlett vállalkozói kultúra (bukott startup utáni újrakezdés lehetősége); és a kedvező adminisztráció-mennyiség voltak a magyar ökoszisztéma leggyengébb vonásai.

8. Táblázat: A 3. fejezet eredményeinek táblázata

\begin{tabular}{|c|c|c|c|c|}
\hline & Propozíció & $\begin{array}{l}\text { Támogatásra } \\
\text { talált }\end{array}$ & $\begin{array}{l}\text { Részben } \\
\text { támogatásra } \\
\text { talált }\end{array}$ & $\begin{array}{l}\text { Nem talált } \\
\text { támogatásra }\end{array}$ \\
\hline P1a & $\begin{array}{l}\text { A magyar startupperek budapesti } \\
\text { frissdiplomások. }\end{array}$ & & $X$ & \\
\hline P1b & $\begin{array}{l}\text { A profit a startup létrehozásának fő } \\
\text { motivációja. }\end{array}$ & & $X$ & \\
\hline P2a & $\begin{array}{l}\text { A magyar startupok számára a } \\
\text { nemzetközi terjeszkedés a legnagyobb } \\
\text { kihívás. }\end{array}$ & $\mathrm{X}$ & & \\
\hline P2b & $\begin{array}{l}\text { A magyar startupok } \\
\text { munkahelyteremtési potenciálja } \\
\text { jelentős. }\end{array}$ & $\mathrm{X}$ & & \\
\hline P2c & $\begin{array}{l}\text { A magyar startupok fö finanszírozási } \\
\text { forrása a kockázati tőke bevonása. }\end{array}$ & & $X$ & \\
\hline P2d & $\begin{array}{l}\text { A hazai startup-ökoszisztéma a } \\
\text { legfontosabb tulajdonságokat tekintve } \\
\text { hasonló a többi V4-es ország startup } \\
\text { ökoszisztémájához }\end{array}$ & $\mathrm{x}$ & & \\
\hline P3a & $\begin{array}{l}\text { A magyar startup ökoszisztéma tagjai a } \\
\text { finanszírozáshoz való hozzáférést } \\
\text { tartják a startup ökoszisztéma } \\
\text { legfontosabb elemének. }\end{array}$ & & $X$ & \\
\hline P3b & $\begin{array}{l}\text { Nincsenek jelentős véleménybeli } \\
\text { különbségek az ökoszisztéma-tagok } \\
\text { alcsoportjai között a startup } \\
\text { ökoszisztéma tényezőinek fontosságát } \\
\text { illetően. }\end{array}$ & & & $X$ \\
\hline P4a & $\begin{array}{l}\text { A magyar startup ökoszisztéma tagjai a } \\
\text { finanszírozáshoz való hozzáférést } \\
\text { tartják a magyar startup ökoszisztéma } \\
\text { legerősebb tulajdonságának. }\end{array}$ & & & $X$ \\
\hline P4b & $\begin{array}{l}\text { Nincsenek jelentős véleménybeli } \\
\text { különbségek az ökoszisztéma tagok } \\
\text { alcsoportjai között a magyar startup } \\
\text { ökoszisztéma tényezőinek értékelését } \\
\text { illetően. }\end{array}$ & & & $X$ \\
\hline
\end{tabular}

Forrás: saját szerkesztés

Ez a fejezet általános megállapításokat mutatott be, hogy segítsen megérteni a startupok viselkedését és tulajdonságait, illetve összegyüjtötte a startup ökoszisztéma fejlettségének kulcstényezőit. Ez a kutatás segíti a startup vállalkozókat, a 
döntéshozókat, illetve a különböző befektetőket abban, hogy megértsék a valós piaci helyzetet, a problémákat és azokat a kihívásokat, amelyekkel a startupperek jelenleg szembenéznek. 


\section{4 Állami részvétel a kockázati tőkepiacon²}

Ez a fejezet egyrészt az állami beavatkozás okára koncentrál, illetve arra, hogy felfedje a kutatók által feltett fő kérdéseket az állami kockázati tőkével kapcsolatban, illetve megpróbáljon válaszolni azokra. Először is két fő csoportra lehet osztani a kockázati tőkepiacon az állami beavatkozást:

1. Tisztán állami kockázati tőke - másnéven direkt beavatkozás. Jellemzője, hogy az állam mind a kockázati tőkealap-kezelö tulajdonosa, mind a kezelt tőkealapé. A privát szektor nincs jelen ebben a típusú beavatkozásban.

2. Állami-privát együttműködés. Két formája lehetséges. Egyik forma: az állam adja a források egy részét, amelyeket privát kockázati tőkealapkezelő társaság menedzsel (hibrid finanszírozás - indirekt beavatkozás). Másik forma: az állami forrásokat kihelyező állami tőkealap-kezelő együtt végez befektetést egy privát forrásokat kihelyező magánpiaci tőkealap-kezelővel azonos időben (co-investment, társbefektetés), illetve ez történhet időben eltolva is (pl. elöször az állam fektetett be, majd egy későbbi körben egy privát szereplö).

A két állami beavatkozási típust értékelő tanulmányokat nagy részletességgel prezentálom ebben a fejezetben. Az állami kockázati tőke jelensége nagy figyelmet kapott a közelmúltban a nemzetközi irodalomban. Nem csak a kutatási terület fejlettségi szintje által megkívánt követelmények különböztetik meg a szakirodalmi áttekintéseket, hanem a vizsgált dimenziók száma és részletessége is (Paré et al., 2015).

Az állami beavatkozás a kockázati tőkepiacon 2018-ig két szakirodalmi áttekintés témája volt (Callagher et al. 2015; Colombo et al. 2016). Mindkettő az 1988-2014-es időszak megállapításait foglalja össze. A narratív áttekintések kategóriájába tartoznak, hiszen nem dokumentálják az adatgyüjtés és az adatelemzés folyamatát, és nem használnak fel gyakorisági mutatókat.

Röviden áttekintjük, hogy mely piaci kudarcok indokoljak az állami beavatkozást a kockázati tőkepiacon, majd szisztematikus szakirodalmi összefoglaló alapján áttekintést adunk az állami kockázati tőkefinanszírozást vizsgáló

\footnotetext{
${ }^{2}$ Ezt a kutatást Jáki Erikával végeztem, a kutatásból készült tanulmány megjelenés alatt van az Acta Oeconomica szakfolyóiratban.
} 
kutatásokról, melyek 2000 és 2018 között a Scimago által minősített folyóiratokban jelentek meg. Az eddigi kutatások általában azzal foglalkoztak, hogy az állami beavatkozás ezen a piacon indokolt-e, illetve hatékony-e.

A kutatásunk nemzetközi viszonylatban biztosít értékes összefoglalást, mely hasznos lehet a döntéshozók és a kockázati tőkések számára, akik jobban meg szeretnék érteni az állami kockázati tőke beavatkozásának nemzetközi példáit. A fejezet másik célja, hogy ösztönözze a terület további kutatását, amely az állami kockázati tőke kezdeményezéseinek megfelelöbb sikerkritériumaira fókuszálhat, ez növelheti a kutatási terület egészének hozzáadott értékét.

\section{1 Állami beavatkozás piaci kudarcok következményeként}

Az állami beavatkozás a kockázati tőkepiacon a piac tulajdonságainak következménye: a megcélzott magvető és startup fázisú cégek nagy kockázatot hordoznak, és a jelenlévő piaci kudarcok akadályozzák a magánbefektetőket. A releváns szakirodalom és a helyi piaci gyakorlatok alapján fontos elemeznünk a piaci kudarcokat (Kovács, 2011 és Karsai, 2004), amelyek eredményeképp a magánszektor képtelen elegendő tőkét biztosítani a magvető fázisú és startup cégeknek. Ennek az alfejezetnek a célja, hogy megválaszolja a fó kutatási kérdést: miért szükséges az állami beavatkozás a szektorban, és ez az érintettség hogyan valósul meg gyakorlatban egy ország piacán.

A piaci kudarcok sok formában megjelenhetnek, és mindegyikük piaci torzulást jelez: problémákat a közjavakkal, monopol vagy oligopol piaci szereplők jelenlétét, aszimmetrikus információt, tranzakciós költségeket és externáliákat (Szentes, 2006, Lovas, 2015). A kockázati tőkepiaci finanszírozásban a következő problémák merülhetnek fel (Lovas, 2015):

- Aszimmetrikus információ: mivel a startup cégek nem rendelkeznek nagymúltú üzleti tevékenységgel, kevés és megbízhatatlan információ áll rendelkezésre a cég múltjáról, és főleg a jövőjéről. Ezért a befektetők számára nehéz felmérni a projekt minőségét és megvalósíthatóságát.

- Magas tranzakciós költségek: a fiatal cégek általában kis tőkét igényelnek, míg minden egyes befektetési folyamat fix költsége magas.

- Externáliák: ezen innovatív startup és magvető fázisú cégek támogatása pozitív makroökonómiai következményekkel járhat a hazai gazdaságban. 
Ezek a piaci kudarcok szükös tőkekínálatot eredményeznek a piacon, amit finanszírozási résnek („financing gap”) is hívnak. A 2007-2013 közötti időszakban a magyar kockázati tőkepiac finanszírozási rése becsülten 165 milliárd forint volt (Deloitte Zrt., 2016).

\subsubsection{Aszimmetrikus információ}

Ahhoz, hogy megtalálják a megfelelő finanszírozó partnert, a magvető és startup fázisban lévő cégek üzleti tervet kell, hogy bemutassanak. Természetesen minden feltaláló, alvállalkozó és vállalkozó hisz az ötletében, de az üzleti tervük nyilván túl optimista. Az üzleti terv alapú döntéshozatalt a szakirodalomban részletesen be van mutatva. Az üzleti és pénzügyi terv készítése során mutatkozó túlzott optimizmus kognitív forrásait Jáki (2010) tárgyalja. Kirsch, Goldfarb és Gera (2009) tanulmányozta a kockázati tőkés döntéshozatali folyamatot a leadott üzleti tervek alapján. Balboni, Bortoluzzi, Tivan, Tracogna és Venier (2014) szakirodalmi összefoglalót nyújtottak a startup cégek növekedésének okairól, és az üzleti tervezésükről. A kockázati tőkés döntéshozók gyakran arra kényszerülnek, hogy gyorsan hozzanak döntéseket. Ilyen helyzetekben a döntéshozók heurisztikákra támaszkodnak a döntések megkönnyítésére.

Minden finanszírozási esetben igaz, hogy az üzleti tervek kidolgozására és értékelésére aszimmetrikus információ jellemző, amit egyszerüsítve hívhatunk bizalomhiánynak a befektetők részéről az eredeti tulajdonosok és leadott üzleti tervük irányában. Paliszkiewicz (2011) a bizalmat fontos tőkebefektetéseket befolyásoló tényezőként azonosította. Az aszimmetrikus információ a kontraszelekció jelenségéhez vezethet, amikor az összes elérhető befektetési opció közül a befektető nem a legjobbat választja az információ hiánya miatt. Például a rossz növekedési kilátásokkal rendelkező „A” cég jó befektetésként festi le magát, és hajlandó átadni a többségi részesedést a befektetésért cserébe. Ezzel szemben a „B” cégnek, amelynek nagyon jók a növekedési kilátásai, nem sikerül vonzó befektetésként feltüntetnie magát és a cégben szeretné tartani a többségi részesedést, ami miatt a befektető az „A” céget választja. Az „A” cég tudta, hogy az értéke alacsony, ezért volt hajlandó feladni a tulajdonjog nagy részét, míg a „B” cég tudta, hogy az ö értéke magas, ezért kérte, hogy megtarthassa a többségi tulajdont. Ez az egyszerü példa jól illusztrálja, hogy müködik a kontraszelekció a befektetési piacon, 
ahhoz hasonlóan, ahogy Akerlof eredeti példájában a citrompiacon müködik (Akerlof, 1978).

Az információs aszimmetria erkölcsi kockázathoz vagy ügynökköltségekhez vezethet a kockázati tőkefinanszírozás területén, azaz vállalkozó nem teljes erőfeszítéssel koncentrál a projekt sikerére a befektetés megszerzése után. Az elméleti modellekben ezt a „rosszul viselkedő ügynök” kockázatának nevezik (Berlinger et al., 2017). Ez az igazán valós kockázat egy újabb ok arra, miért olyan drága és nehezen megszerezhető a finanszírozás ebben a korai szakaszban.

Az üzleti terv majdnem minden klasszikus részéből (marketing és értékesítési terv, müködési terv, befektetési terv, szervezeti struktúra) következhet nagyfokú bizonytalanság és ebből kifolyólag súlyos információs aszimmetria, ami alig kezelhető. A magvető fázisú cégek nem tudnak részletes termék/szolgáltatásleírással szolgálni, főként nem az IT-szektorban. A kockázati tőkebefektetők általában elutasítják ezeket a cégeket az üzletük alulfejlettsége miatt. A magvető fázisú cégek esetében kihívás az alapító számára, hogy a termék/szolgáltatás pontos ismerete nélkül részletes marketing és értékesitési tervet hozzon létre. Mivel a startup cégek már rendelkeznek működő prototípussal, a marketing és értékesítési terv fontos része az üzletük fejlesztésének. A marketing/értékesítési vezető szakértelme és tapasztalata nagy fontosságú, amit meggyőzően kell kommunikálni a befektető felé. Az iparági elemzés elkészítése gyakran küzdelmes, mivel a termék/szolgáltatás teljesen új, érintetlen, „kék óceán” iparágat teremthet (Kim és Mauborgne, 2004). A magvető fázisú cégeknek tipikusan csak vázlatos fogalma van a pontos müködési folyamatról, mivel még az üzlet központi koncepciója sem végleges. A startup cégek általában részletesebben írják ezt le, ami hitelesebbé teszi a müködési tervet. Végül, a magvető stádiumú és startup cégek a befektetett tőke nagy részét általában a munkaerőre és a személyi jellegü költségekre fordítják, ezért az üzleti terv egyik legfontosabb része a menedzsment csapat és a szervezet bemutatása (Sahlman, 1997).

Mindezek alapján láthatjuk, hogy a magvető fázisú és a startup cégek főként egy üzleti ötletet próbálnak meg eladni. A szervezet nem teljes, a cég kínálata, kereslete és ipari kockázatai aligha előre jelezhetőek. A kezdeti befektetést a szellemi tulajdonra, K+F-re vagy marketingre költik, aminek a hatékonyságát nehéz mérni. Érthető, miért az üzleti angyalok és az úgynevezett „család, barátok és bolondok” köre a magvető stádiumú cégek fő tőkeforrásai, hiszen az információs aszimmetria általában túl magas a klasszikus intézményes kockázati tőkebefektetőknek. Mivel a 
befektetők több (ám még mindig nem elégséges) információval rendelkeznek a startup cégekről, a kockázati tőkealapok gyakrabban összpontosítanak startupokra, mint magvető fázisú cégekre.

\subsubsection{Tranzakciós költségek}

Ahhoz, hogy lássuk, a tranzakciós költségek piaci kudarca hogyan jelenik meg a kockázati tőkepiacon, tekintsük át a kockázati tőkebefektetés folyamatát. Az alapkezelő a likvid forrásokat a különböző befektetőktől a kockázati tőkealapban gyüjti össze. Az alapkezelő az alapból a céltársaságokba fektet be az alapkezelési szabályzatban rögzített befektetési irányelvekkel összhangban. Az alap befektetői megtérülésben, hozamban érdekeltek. A befektetési döntéseket óvatosan kell az alapkezelő menedzsmentjének meghoznia, hogy a hozammal kapcsolatos elvárásokat teljesítse. Ahhoz, hogy megértsük, a tranzakciós költségek miért jelentenek piaci kudarcot a kockázati tőkepiacon, bemutatásra kerül a döntéshozatali folyamatot. A befektetési folyamat négy különböző fázisból áll:

I. Befektetési döntés. A befektetési szerződés aláírása előtt a befektetési menedzsernek el kell készítenie a befektetési javaslatot, amit a döntéshozó testület megvitat és dönt róla. Elöször a befektetési menedzsernek kell megszürnie a finanszírozási kérvényeket, majd körültekintően értékelnie a kiválasztott projekteket az alapkezelő jogi és kockázatkezelési divíziójával együttmüködve. A törvényi elöírás alapján a kockázati tőkealap-kezelőnek független kockázatelemző területet kell müködtetnie. Jogi, pénzügyi, iparági vagy egyéb tárgyú átvilágítást végezhetnek, mely folyamatot a befektetési menedzser koordinál. Összességében legalább három terület szükséges a befektetési javaslat elkészítéséhez: befektetési menedzserek, jogi szakértők, kockázatkezelési szakértők. A befektetési javaslatot vagy egy testület (Igazgatóság, Bizottság) hozza meg, vagy a Vezérigazgató egymaga. Pozitív döntés után a céltársaság és az alapkezelő az alap nevében aláírja a befektetési szerződést.

II. Folyósitás. A szerződés aláírása és a cég alapítása után következik az első folyósítás. Ezt a pénzügyi és jogi szerződéses kötelességek ellenőrzése előzi meg. A felülvizsgálatot a maximális körültekintés érdekében a befektetési menedzser, a jogi szakértő, valamint a kockázatkezelési terület végzi. 
III. Portfoliókezelés. A folyósítás után a céltársaságot folyamatosan monitorozni kell negyedéves, féléves, de legalább éves adatszolgáltatás alapján, amely gyakoriságot a felek a befektetési szerződésben határoznak meg. A monitoring feladata az üzleti terv megvalósítása, a pénzügyi adatok és a megkötött vevői és szállítói beszállítói szerződések ellenőrzése, illetve az összes kockázati tényező felmérése. A monitorozáshoz szükséges jelentést a kockázatkezelési területnek is felül kell vizsgálnia. A tulajdonosi joggyakorlás során az alapkezelő képviselője mandátumot kap, mely alapján részt vesz a taggyülésen, vagy közgyülésen és szavaz. Az alapkezelő cég jellemzően delegál egy tagot a felügyelőbizottságba, és/vagy kijelöl egy igazgatótanács tagot, amely jogokat szintén a befektetési szerződésben rögzítik. Összességében tehát a portfoliókezelési folyamatban a portfoliókezelő, a kockázatkezelés és a jogi szakértők müködnek együtt.

IV. Exit. Sikeres befektetés esetében az alap a cégben lévő részesedés értékesítésével realizálja hozamát. Ebben a folyamatban szintén szükség van a jogi és kockázatkezelési szakértők aktív közremüködésére a portfoliókezelő véleménye mellett.

Összességében elmondható, hogy a tipikus befektetési döntésből, folyósításból, portfoliókezelésből és exitből álló folyamat hosszú, összetett és drága. Ezért nem gazdaságos az alapkezelő cégnek egy bizonyos összeg alatt foglalkozni a befektetési lehetőséggel. Berlinger (2019) elméleti modellje rávilágít arra, hogy az állam segíthet áthidalni ezt a piaci kudarcot támogatott befektetés biztosításával, segítve a projektet egy olyan stádium elérésében, amelyben a magánszektor is hajlandó tovább finanszírozni azt.

\subsubsection{Externáliák}

A magas tranzakciós költségek és a súlyos aszimmetrikus információval kapcsolatos problémák akadályozzák a magánbefektetőket, hogy aktívabbak legyenek a korai fázisú vállalkozások kockázati tőkefinanszírozásában. A pénzügyi források nélkül a magvető fázisú és startup cégeknek sok ötlete nem kerül megvalósításra. Ezért a fiatal cégek finanszírozását segítő állami programok létjogosultságát alátámaszthatják a kapcsolódó pozitív externáliák. Karsai (2013) szerint az állami beavatkozás szükséges a kockázati tőkepiacon, mivel az állam a profitteremtésen kívül más célokat is szem elött tart. Ezek közé tartozhat a helyi innováció ösztönzése, társadalmi és regionális gazdasági fejlődés támogatása, új 
munkahelyek teremtése, a társadalmi szolgáltatásokra költhető adóbevétel növelése, valamint a fenntartható fejlődés és a megújuló energiamegoldások előmozdítása. Ha a vállalkozók nem tudnak befektetőket találni saját országukban, külföldi befektetőkhöz fordulnak és külföldre viszik az ötletüket. Berlinger et al. (2017) elméleti modellje megmutatja, hogy az optimális méretű állami támogatás a vállalkozót a vállalkozás sikerének elérése érdekében tett komoly erőfeszítésre készteti, így csökkentve az erkölcsi kockázatot. Emellett a társadalmi jólétet is növeli és nem szorítja ki a privát befektetöket, hanem pont növeli a privát befektetési tevékenységet is. Bár a pozitív externália az egyik legerősebb és legkönnyebben érthető magyarázat az állami beavatkozásra, ezeknek az előnyöknek a számszerüsítése rendkívül nehéz.

Szintén fontos megemlíteni a negatív externáliákat, mivel a rossz szektorban megvalósított befektetések rengeteg negatív hatással járhatnak. A negatív externáliákat elöállító cégek közé általában a dohányvállalatok, a fegyvergyártók, a kaszinók, a pornográf tartalmak gyártásával foglalkozó cégek sorolhatók. Ez a lista egybeesik azon cégekkel, amelyek nem kaphatnak támogatást a magyar állam GINOP kockázati tőkeprogramjától (Palyazat.gov.hu, 2017). Összefoglalásként elmondható, hogy az állami befektetéseknek a pozitív externáliákat kell előmozdítaniuk. A fejezet fennmaradó részében kvalitatív szisztematikus szakirodalmi összefoglaló kerül bemutatásra, amely a világ különböző részein megvalósított kockázati tőkeprogramokat vizsgálja.

\subsection{A kvalitatív szisztematikus szakirodalmi összefoglaló kutatási módszertana}

A szisztematikus szakirodalmi összefoglalóknak jól dokumentált és megismételhető adatgyüjtési és adatelemzési folyamatot kell követniük (Paré et al., 2015). Először a tanulmány módszertana kerül bemutatásra a következő alfejezetben.

\subsubsection{Adatgyüjtési módszertan}

2018. 10. 31-én történt a szisztematikus adatgyüjtés. A szakirodalom legyüjtéséhez a következő adatbázisokat használtuk: Business Source Complete, Academic Search Complete, Business Source Premier, EconLit illetve ScienceDirect. Az azonosítás folyamata a következőkből állt: először is egy keresés volt lefuttatva a „venture capital”, és a „government”, vagy a „state” szavakra a címek, absztraktok, vagy a publikált cikkek kulcsszavai között. Ez a keresés 128 cikkből álló listát 
eredményezett. Második lépésként kizártuk azokat a folyóiratcikkeket, amelyek nem lektorált angol nyelvü cikkek voltak. Így a monográfiák, $\mathrm{PhD}$ disszertációk, dolgozatok, szerkesztői jegyzetek, szimpóziumok, prezentációdiák és könyvkritikák kizárásra kerültek a keresésből. Harmadik lépésként kizárásra kerültek a Scimago által nem minősített cikkek. Ezután következett az absztraktok elemzése, melynek során azon cikkek kerültek kizárásra, amelyek nem az állami kockázati tőkebefektetők pénzügyi forrásbiztosítói szerepét vizsgálták. Ez 29 releváns cikket eredményezett. Végül a cikkek alapos átolvasása után további három cikk került kizárásra. A legtöbb cikk azért került kizárásra, mert nem az állami kockázati tőke szereplöit vizsgálta. Egyes esetekben a cikkek a vállalati kockázati tőkepiacot kutatták, az államot törvényhozóként említették. A folyamat végén 26 releváns cikk került azonosításra, ezek alkotják az adatbázist.

\subsubsection{Adatelemzési módszertan}

A fejezet a kvalitatív szisztematikus szakirodalmi összefoglalók adatelemzési folyamatát követi (Paré et al., 2015; Bandara et al., 2011). A fejezet átfogó képet kíván adni az állami kockázati tőkéről szóló irodalomról. Ennek érdekében az adatbázisunkat alkotó cikkeket több dimenzió szerint kategorizáljuk. A cikkek felosztását évek, kiadók, az adatgyüjtés földrajzi helyszíne, az alkalmazott módszertan, valamint a felhasznált adatbázis típusa szerint lesznek bemutatva. A cikkek alapos elolvasása után azonosításra került egy közös szál, amelyet kvalitatív tartalomelemzés segítségével lehetséges megfelelően elemezni. Minden cikk tartalmazza, hogy a korai fázisú állami beavatkozás a kockázati tőkepiacon sikeres-e vagy sem, illetve, hogy milyen formát ölt. A kvalitatív elemzés szempontjából kulcsfontosságú ezen benyomások összegyüjtése, kategorizálása és az eredmények szisztematikus bemutatása.

Az elemzés induktív megközelítést alkalmaz a tartalomelemzéshez (Mayring, 2004), ami azt jelenti, hogy először in-vivo kódolást készítettünk - ez a gondolati egységek azonosítását jelentette a cikkek absztrakt, bevezető és befejező részeiben, amelyek következtetések vagy megfigyelések voltak az államok szerepéről a korai szakaszú vállalatfinanszírozás piacán. Három cikk (Wonglimpiyarat, 2011; Cohen et al., 2012; Gill, 2015) esetében azonban a cikkek más részei tartalmazták a megfelelő gondolati egységeket, mivel eltérö volt a felépítésük. Az in-vivo kódok vagy gondolati egységek lehetnek szavak, mondatrészek, mondatok vagy akár több 
mondat, amelyek koherens egészet alkotnak. A tanulmány figyelembe veszi a hibrid alapokkal, az állam által támogatott inkubátorokkal, akcelerátorokkal vagy egyéb korai fázisú finanszírozási eszközökkel kapcsolatos megjegyzéseket is, mivel fontos, hogy átfogó képet kapjunk a témáról, és ne csak a tisztán állami kockázati tőkebefektetőkről gyüjtsünk adatokat. A fejezet a szerzők azon ajánlásairól is prezentál adatokat, amelyek segítségével hatékonyabbá tehetőek a korai fázisú állami finanszírozási kezdeményezések.

Az elemzés során az in-vivo kódokat elöször a jelentkező kategóriákba soroljuk (Mayring, 2004). Miután minden in-vivo kódot sikeresen összekapcsolunk egy kategóriával, átfogó témák és altémák lettek kidolgozva. Altémákként esetünkben a vizsgált finanszírozás releváns típusát kapcsoljuk az egyes kategóriákhoz. A kategóriákat tovább tematizáltuk aszerint, hogy pozitív vagy negatív értékelések vagy ajánlások-e az állami intervencióról a korai szakaszú finanszírozási piacon.

\subsubsection{Kutatási kérdések}

Annak ellenére, hogy a tanulmány célja az állami kockázati tőkével kapcsolatos szakirodalomban felmerülő fó kutatási irányok feltárása és az eredmények különböző dimenziók szerinti kategorizálása, mégis megfogalmaztunk konkrét kutatási kérdéseket és propozíciókat.

9. táblázat: Kutatási kérdések a 4. fejezethez

1. A kutatási terület cikkei milyen minősítésủ Scimago által minősített folyóiratban lettek publikálva?

2. Melyek a fő módszertanok, melyeket a kutatási terület cikkei alkalmaznak?

3. Mi váltotta ki a kutatók érdeklődését a kutatási területen 2000 és 2018 között?

4. Milyen földrajzi területet vizsgálnak a cikkek?

5. Melyek az állami beavatkozás fő típusai, amelyeket a cikkek vizsgálnak?

6. A kutatók hogyan ítélik meg a különböző típusú beavatkozásokat?

7. Van olyan típusú beavatkozás, amelyet a kutatók csak pozitív hatásokkal kapcsoltak össze?

8. Van kapcsolat a tanulmányozott földrajzi terület és az állami beavatkozás megítélése között?

9. Milyen fő ajánlásokat fogalmaznak meg a kutatók a döntéshozók számára?

Forrás: saját szerkesztés 
Ez a fejezet először a folyóiratokra, a módszertanokra, a vizsgált földrajzi területre és a publikált cikkek relevanciájára összpontosít (1-4. kérdés) Ezután a figyelem a kockázati tőkepiacon történő különböző állami beavatkozási típusokra terelődik a következő kutatási kérdésekben. A cél a tanulmányozott intervenciós módszerek azonosítása (5. kérdés) és ezen cikkek általi megítélésének feltérképezése (6-7. kérdés). Mivel az eredmények az földrajzi területe alapján eltérhetnek, fontos ezeket a különbségeket is azonosítani (8. kérdés). Végül ennek a fejezetnek a célja a szerzők törvényhozóknak szóló ajánlásainak összefoglalása, hogy segítsük a döntéshozókat a jövőbeni állami kockázati tőkeprogramok kialakítása és végrehajtása során (9. kérdés). A következő táblázat a propozíciókat tartalmazza.

10. táblázat: Propozíciók a 4. fejezethez

1a propozíció: A kutatási terület cikkei a legmagasabb minőségü Scimago által minősített folyóiratokban jelentek meg.

1b propozíció: A kutatási terület cikkei elsősorban ökonometriai elemzést alkalmaznak kutatási módszertanként.

1c propozíció: A kutatási terület iránti érdeklődés 2000 és 2018 között elsősorban a különböző gazdasági válságokra adott állami válaszoknak köszönhetö.

1d propozíció: A cikkek elsősorban az amerikai állami kockázatitőke-kezdeményezéseket vizsgálják.

2a propozíció: A cikkek elsősorban a kockázati tőkepiac állami beavatkozásának közvetlen és a privát szektorral partnerségben végrehajtott formáját vizsgálják.

2b propozíció: A cikkek elsősorban negatív hatásokat társítanak a közvetlen állami beavatkozáshoz.

2c propozíció: A cikkek pozitív és negatív hatásokat egyformán társítanak az állami-privát partnerségü kockázati tőkéhez.

2d propozíció: Nincs olyan beavatkozási forma, amelyhez csak pozitív hatásokat társítanak.

Forrás: saját szerkesztés

\subsection{Az adatbázis kategorizálása és elemzése}

A szakcikkek alapján készített adatbázist egyrészt leíró statisztikai módszerrel elemeztük, emellett azonosítottuk a cikkek kutatási témáit, azok konkrét következtetéseivel és a vizsgált földrajzi területtel együtt. A cél a kockázati tőkepiac állami beavatkozásával foglalkozó kutatások tendenciáinak meghatározása.

\subsubsection{A kutatási terület folyóiratai}

A kockázati tőkepiac állami beavatkozását vizsgáló cikkek többségét 15, a Scimago által Q1 vagy Q2 besorolással ellátott folyóirat jelentette meg (1. kérdés), 
ez támogatja az la propozíciót - „A kutatási terület cikkei a legmagasabb minőségü Scimago által minösitett folyóiratokban jelentek meg”. Négy folyóirat jelentetett meg egynél több tanulmányt. A Journal of Business Venturing és a Venture Capital Journal 3-4 tanulmányt publikáltak. 5 tanulmány jelent meg az European Planning Studies-ban, és kettő a Research Policy-ban. A 26-ból 15 cikk Q1 minősítésü folyóiratokban jelent meg, a maradék többsége Q2 minősítésüben, 1 db Q3 minősítésüben. A Scimago által Q4 besorolással illetett folyóiratokban nem jelent meg egy cikk sem az állami kockázati tőkével kapcsolatban 2000 és 2018 között.

11. táblázat: A kutatási terület Scimago általi besorolás szerinti felosztása

\begin{tabular}{|c|c|c|c|}
\hline Folyóirat címe & Év & $\begin{array}{l}\text { Publikációk } \\
\text { száma }\end{array}$ & $\begin{array}{c}\text { Scimago } \\
\text { szerinti } \\
\text { besorolás }\end{array}$ \\
\hline European Business Organization Law Review & 2014 & 1 & Q2 \\
\hline \multirow{5}{*}{ European Planning Studies } & 2007 & \multirow{5}{*}{5} & Q1 \\
\hline & 2008 & & Q1 \\
\hline & 2008 & & Q1 \\
\hline & 2017 & & Q1 \\
\hline & 2017 & & \\
\hline Global Economy Journal & 2014 & 1 & $\mathrm{Q} 2$ \\
\hline International Journal of Economics and Business & 2007 & 1 & Q2 \\
\hline Israel Affairs & 2012 & 1 & Q2 \\
\hline \multirow{3}{*}{ Journal of Business Venturing } & 2007 & \multirow{3}{*}{3} & Q1 \\
\hline & 2015 & & Q2 \\
\hline & 2016 & & $\begin{array}{l}\text { Q1 } \\
\text { Q1 }\end{array}$ \\
\hline Journal of Commercial Biotechnology & 2011 & 1 & Q3 \\
\hline Journal of Corporate Finance & 2017 & 1 & Q1 \\
\hline Journal of High Technology Management Research & 2011 & 1 & Q2 \\
\hline Journal of International Entrepreneurship & 2009 & 1 & $\mathrm{Q} 2$ \\
\hline Local Economy & 2015 & 1 & Q2 \\
\hline \multirow{2}{*}{ Research Policy } & 2014 & \multirow{2}{*}{2} & Q1 \\
\hline & 2018 & & Q1 \\
\hline Review of Finance & 2015 & 1 & Q1 \\
\hline Small Business Economics & 2018 & 1 & Q1 \\
\hline Technovation & 2016 & 1 & Q1 \\
\hline \multirow{4}{*}{ Venture Capital } & 2005 & \multirow{4}{*}{4} & Q2 \\
\hline & 2015 & & Q1 \\
\hline & 2015 & & Q1 \\
\hline & 2018 & & Q2 \\
\hline \multirow{3}{*}{ Összesen } & & 15 & Q1 \\
\hline & & 10 & Q2 \\
\hline & & 1 & Q3 \\
\hline
\end{tabular}


Forrás: saját szerkesztés

\subsubsection{A cikkek által felhasznált adatbázisok és módszertanok}

A cikkekben alkalmazott módszertani megközelítések (2. kérdés) meglehetősen változatosak az állami kockázati tőke területén. Az esettanulmányok (ideértve az összehasonlító esettanulmányokat is) és az ökonometriai elemzések a legnépszerübb kutatási módszerek, amelyek adatbázisunkban nyolc, illetve tíz cikkre jellemzőek. Ez igazolja, hogy az ökonometriai elemzés és az esettanulmány a legkedveltebb módszertan a kutatási területen, így az 1 b propozíció - „A kutatási terület cikkei elsősorban ökonometriai elemzést alkalmaznak kutatási módszertanként” támogatásra talált.

Az esettanulmány a legalkalmasabb kutatási módszer a témával kapcsolatos helyi tapasztalataik felhasználására, ami indokolja a népszerüségét azon szerzők között, akik jól ismerik azt, hogy az állami beavatkozás hogyan alakította országuk startup ökoszisztémáját (Avnimelech et al., 2007; Avnimelech, 2008; Cohen et al., 2012). Az adatgyüjtés ezen kívül különösen nehéz ezen a területen. Ahogy Zangh (2014, 112. o) felhívta rá a figyelmet: „külső kutató számára meglehetősen nehéz megszerezni az eredeti szerződéseket és megállapodásokat, vagy egyéb dokumentumokat, amelyek leirják e mechanizmusok alkalmazását a felek között, akár a kockázati tőkealapoktól, akár a cégektöl, amelyekbe befektettek. Ilyen körülmények között ezeknek az ösztönzö mechanizmusoknak csak közvetett bizonyitéka nyerhetö interjúk készitésével és másodlagos források megkeresésével.".

Mivel ezen a területen az egyik legfőbb kutatási irány az állami beavatkozás hatékonyságának felmérése, az ökonometriai elemzés is a kutatók egyik kedvelt módszere. Ezen vizsgálatokhoz a kutatók hozzáférést szereztek egy nagy, lehetőleg nemzetközi cégadatbázishoz, és modellt készítenek az állami befektetések hatásának tesztelésére. Ezt általában olyan modell segítségével teszik meg, amely a vizsgált portfóliócégek hatékonyságának helyettesítésére kiválasztott változót magyarázza. Az állami befektetés az egyik magyarázó változó, és tesztelik, hogy van-e szignifikáns hatása a választott hatékonysági változóra, kontrollálva az egyéb változókra, amelyek befolyásolhatják a függő változót. Érdekes, hogy ezek a cikkek különböző konklúziókra jutnak attól függően, hogy mi a vizsgált hatékonysági változó és a földrajzi terület. 
Elméleti modellt összesen egy cikk alkalmazott az állami beavatkozással kapcsolatban. Ez a megközelítés igen ritka ezen a területen, ami valószínűleg annak köszönhető, hogy az érdeklődés az állam szerepéről alkotott empirikus megállapításokra irányul. Csak egy cikk alkalmazott kizárólag kérdőíves elemzést, ennek oka, hogy a területen nehéz az intézményeket válaszadásra bírni.

12. táblázat: Alkalmazott módszertan a cikkekben

\begin{tabular}{lll} 
Módszertan & A módszertant alkalmazó cikkek & Db \\
\hline Általános egyensúlyi modell & Bauer és Burghof, 2007 & 1 \\
\hline Esettanulmány & $\begin{array}{l}\text { Cohen et al., 2012; Gill, 2015; Zhang, 2014; } \\
\text { Avnimelech, 2008; Wonglimpiyarat, 2016 }\end{array}$ & 5 \\
\hline Összehasonlító & Wonglimpiyarat, 2011; Avnimelech et al., 2007; & 4 \\
esettanulmány & Baldock és Mason, 2015; Heger et al., 2005 & \\
\hline Kérdóívelemzés & Bilau et al., 2017, Frenkel et al., 2008 & 2 \\
\hline Vegyes kutatási módszertan & Tucker et al., 2011; Karsai, 2018; Wray, 2015 & 3 \\
\hline Q módszertan & Jung et al., 2017 & 1 \\
\hline Ökonometriai elemzés & $\begin{array}{l}\text { Herrera-Echeverri et al., 2014; Standaert és Manigart, } \\
\text { 2018; Grilli és Murtinu, 2014; Cumming et al., 2017; }\end{array}$ & \\
& $\begin{array}{l}\text { Guerini és Quas, 2016; Alperovych et al., 2015; } \\
\text { Cumming és Johan, 2009; Milosevic, 2018; Brander } \\
\text { et al., 2015; Cumming, 2007 }\end{array}$ & \\
\hline
\end{tabular}

Forrás: saját szerkesztés

A felhasznált 26 cikkből 17 (Heger et al. 2005; Bauer és Burghof 2007; Cohen et al. 2012; Gill, 2015; Avnimelech, 2008; Tucker et al., 2011; Avnimelech et al., 2007; Herrera-Echeverri et al., 2014; Wonglimpiyarat, 2016; Grilli és Murtinu, 2014; Cumming et al., 2017; Guerini és Quas, 2016; Alperovych et al., 2015; Cumming és Johan, 2009; Milosevic, 2018; Brander et al., 2015; Cumming, 2007) használt kizárólag szekunder adatot a kutatás elvégzéséhez. Ezek főleg nyilvánosan hozzáférhető adatbázisokból, kutatási intézetek jelentéseiből, egyesületektől, bizottságoktól, bankoktól, valamint más kutatók tanulmányaiból származó kvantitatív adatok voltak. Az ökonometriai tanulmányok bizonyítják, hogy a szekunder adatok felhasználása a kutatások során kedvelt módszertan a területen, mivel nehéz állami és magán befektetőktől primer adatot szerezni a kutatáshoz.

\subsubsection{A cikkek relevanciája}

A cikkek alapján két fő kutatási irány azonosítható: az állami beavatkozás oka és az állami beavatkozás hatása (1d. 13. ábra). Annak ellenére, hogy évente számos jelentést írtak az egész világon az állami beavatkozás okáról és hatékonyságáról a 
kockázati tőkepiacon, csak 26 cikket publikált Scimago által minősített folyóirat 2000 és 2018 között. A Scimago által minősített folyóiratokban megjelent minden egyes cikk szigorú ellenőrzésen (review) esett át. Minden kutató számára fontos kérdés, hogy miért pont ezeket a tanulmányokat választották ki publikációra, valamint az, hogy mi váltotta ki az érdeklődést a kutatási területtel kapcsolatban (3. kérdés). A cikkek zöme egy-egy pénzügyi válság miatt bír relevanciával. Ezek a cikkek a piaci változásokat kutatták, illetve ezeknek fényében az államok válságra adott válaszait és/vagy az állami beavatkozás hatékonyságát.

- A 2000-es dot-com válság nagy mértékben hatott a technológiai iparra és a fiatal technológiai startupokra is. Heger és szerzőtársai (2005) 1990-2005 közötti történelmi áttekintéssel szolgált az Egyesült Királyság és Németország kockázati tőkepiacáról és az állam szerepéröl. Frenkel és szerzőtársai (2008) az izraeli kockázati tőkepiacot vizsgálták, mivel az állami technológiai inkubátorok itt 2000-ben kezdték meg müködésüket, rögtön a dot-com válság után. Frenkel és szerzőtársai kiemelték a PTIP (Public Technological Incubator Program) jelentőségét az izraeli kockázati tőkepiacon. Avnimelech (2008) tanulmánya ugyanezen a premisszán alapszik, de ő a startup ökoszisztéma egészére fókuszál, és az izraeli innovációt és technológiai politikát kutatja. Avnimelech és szerzőtársai (2007), illetve Wonglimpiyarat (2016) indíttatását erősíti az izraeli Yozma program sikere, míg Cohen és szerzőtársai (2012) föként az Office of the Chief Scientist programra koncentrálnak.

- A 2008-as pénzügyi világválság kezdete után számos szerző fogalmazott meg javaslatokat az általuk vizsgált ország állama számára - például Wonglimpiyarat (2011) a thaiföldi, Cohen és szerzőtársai (2012) az izraeli, Zhang (2014) a kínai és Gill (2015) a brit állam számára. A cikkek egy csoportja a válságra adott állami válaszoktat elemezte egyes országok esetében. Bilau és szerzőtársai (2017) a portugál állam 2008-as válságra adott reakcióját elemezte az üzleti angyalok támogatására fókuszálva. Baldock és Mason (2015), valamint Wray (2015) az Egyesült Királyság reakciójával foglalkozik. Az EU kockázati tőkeprogramjai adják Karsai (2018), illetve Grilli és Murtinu (2014) cikkeinek relevanciáját. Az ausztrál állam kockázati tőkeprogramjai ihlették Cumming és Johan (2009) munkáját. Összegzésképpen a legtöbb cikk az állami kezdeményezéseket vizsgálta, amelyek gazdasági válságokra adott válaszok voltak, így az $1 c$ propozíció - „A kutatási terület iránti érdeklödés 2000 és 2018 között elsősorban 
a különbözö gazdasági válságokra adott állami válaszoknak köszönhetö” támogatásra talált.

Van két kiugró elem. Bauer és Burghof (2007) elméleti szemszögből vizsgálták az állami intézkedéseket. Herrera-Echeverri és szerzőtársai (2014) indíttatása is pusztán elméleti, mivel ők azt kívánják feltárni, hogy a neoklasszikus vagy a keynesi elméletek az állami beavatkozásról előnyösek-e a feltörekvő piacoknak a kockázati tőkepiacok egészségének szempontjából.

13. ábra: Azonosított kutatási tendenciák az évek során

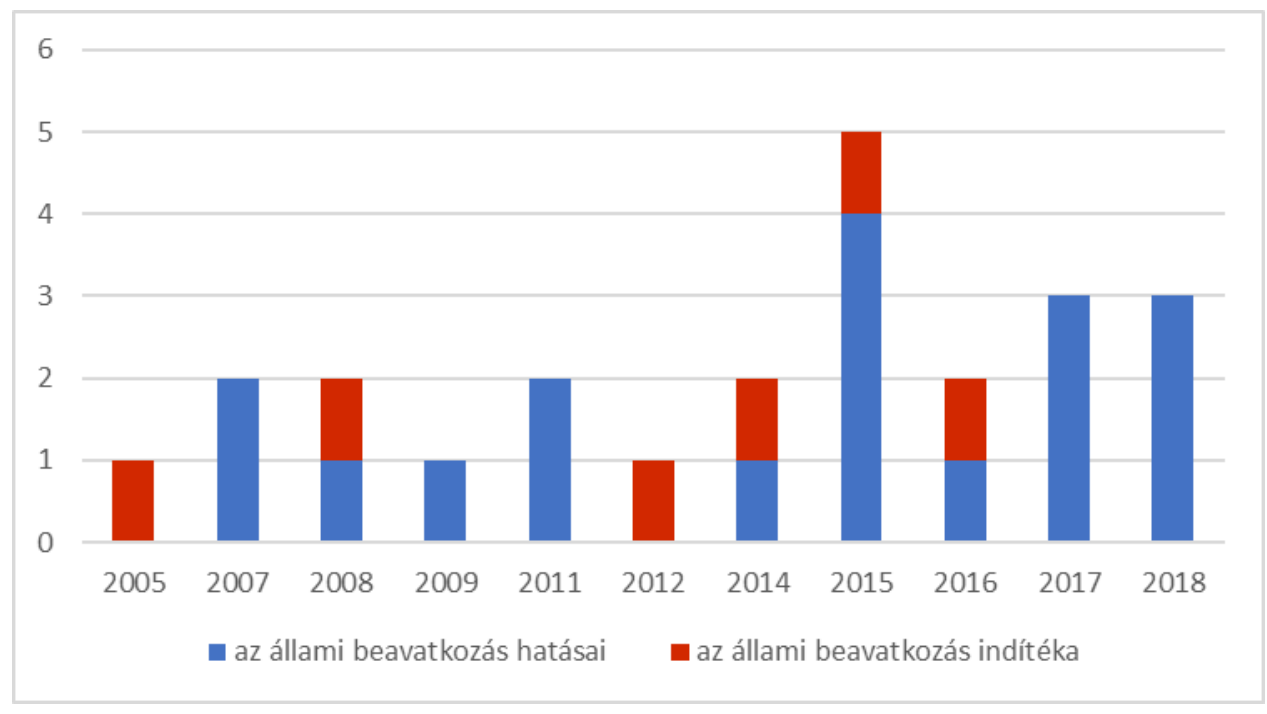

Forrás: saját szerkesztés

\subsubsection{A szerzö származása a vizsgált földrajzi területhez képest}

A szakcikkeket összesen 56 szerző írta, melyböl 26 szerző jelölt meg munkahelyként európai egyetemet vagy kutatóintézetet. Hatan az Egyesült Királyság, öten Németország vagy Olaszország egyik egyetemét. Francia, belga, portugál, holland és magyar szerzők is voltak a kiválasztott cikkek szerzői között. A kutatások alapos elemzést nyújtanak az európai tőkepiacról. A többi 30 szerző nem európai. Tízen izraeli kutatók, akik az izraeli állam indítékait, módszereit és hatékonyságát mutatják be. Nyolc kutató volt kanadai, három koreai, három amerikai, kettő thaiföldi és kettő kolumbiai, és végül egy ausztrál és egy kínai.

A 26 cikkből 9 különböző országokból származó kutatók együttműködésének eredménye (Heger et al., 2005; Cumming és Johan, 2009; Herrera-Echeverri et al., 2014; Alperovych et al., 2015; Brander et al., 2015; Guerini és Quas, 2016; Bilau et al., 2017; Jung et al., 2017; Cumming et al., 2017). Ebből a kilenc cikkből öt az európai piacot vizsgálja. A publikáció dátumáról elmondható, hogy a legkorábbi cikk 
Heger et al., (2005), amely különbőző európai kutatók munkája, akik az Egyesült Királyság és Németország állami alapjaival foglalkoznak az Európai Gazdasági Kutatási Központtal és az Exeteri Egyetemmel együttmüködésben. Jung és szerzőtársai (2017) a dél-koreai kockázati tőkepiacot tanulmányozták a Szöuli Nemzeti Egyetemmel és a Dél-Illinois-i Egyetemmel együttmüködve. Cumming és Johan (2009) az ausztrál kockázati tőkepiacot vizsgálta annak ellenére, hogy kanadai és új-zélandi szerzőkről van szó. Két tanulmány globális tendenciákat elemzett (Herrera-Echeverri et al., 2014; Brander et al., 2015).

A szerzők által megjelölt kutatási intézmény (pl. az egyetemek, intézetek) székhelyét és a vizsgálat tárgyát képező országot összehasonlítva - a nemzetközi együttműködésből származó cikkektől eltekintve - megállapítható, hogy ezek öt esetet kivéve megegyeznek, azaz a kutatók saját országukat vizsgálták. Zhang (2014) a Koreai Egyetem jogi karáról ,a kínai hazai kockázati tőke működésének ösztönző mechanizmusait az amerikai kockázati tőkés tapasztalattal összehasonlítva” (107. o.) tanulmányozta. A New York-i Cumming (2007) az ausztrál kockázati tőkepiacot, míg az ausztrál Wray (2015) Északkelet-Angliát vizsgálta. A thaiföldi Wonglimpiyarat (2016) az izraeli Yozma programot elemezte. Wonglimpiyarat azt állítja, hogy ennek a programnak az ismerete hasznos lehet más országok számára, amelyek a csúcstechnológiai startup ökoszisztémájuk fejlesztésére törekednek.

A 14. ábra mutatja, hogy a cikkek hogyan oszlanak meg a vizsgált földrajzi területek szerint. A cikkek többsége csak egyetlen ország adataival foglalkozik. A legtöbb cikk csak az EU-ból származó adatokat vizsgálta, és meglepő módon csak két cikk foglalkozott az Egyesült Államokkal (amely az egyik legérettebb kockázati tőkepiaccal rendelkezik), ezért az 1d propozíció - „A cikkek elsősorban az amerikai állami kockázatitőke-kezdeményezéseket vizsgálják” - nem talált támogatásra.

A legnépszerübb tanulmányozott országok az Egyesült Királyság és Izrael voltak. Az Európai Uniót vizsgáló cikkek közül öt cikk több EU-országot vizsgált, négy cikk egy-egy országra - Franciaországra, Belgiumra, Németországra vagy Portugáliára - koncentrált. Másrészt több cikk tanulmányozta az izraeli piacot, néhányan közülük az izraeli Yozma programot tartják követendő példának. Néhányan az ázsiai, a kanadai és az ausztrál piacot vizsgálták. Herrera-Echeverri és szerzőtársai (2014) a közvetlen külföldi tőkebefektetések, az intézményi minőség és az állam méretének a kockázati tőkepiaci tevékenységre gyakorolt hatását vizsgálták a feltörekvő piacokon. Arra a következtetésre jutottak, hogy az állami kiadások 
hátrányosan befolyásolják a kockázati tőkepiaci szereplök tevékenységét. A 14. ábra alapján megállapítható, hogy e cikkek elemzése globális áttekintést nyújthat a kockázati tőkepiaci állami intervenciók főbb tendenciáiról.

14. ábra: A cikkek megoszlása vizsgált területük szerint

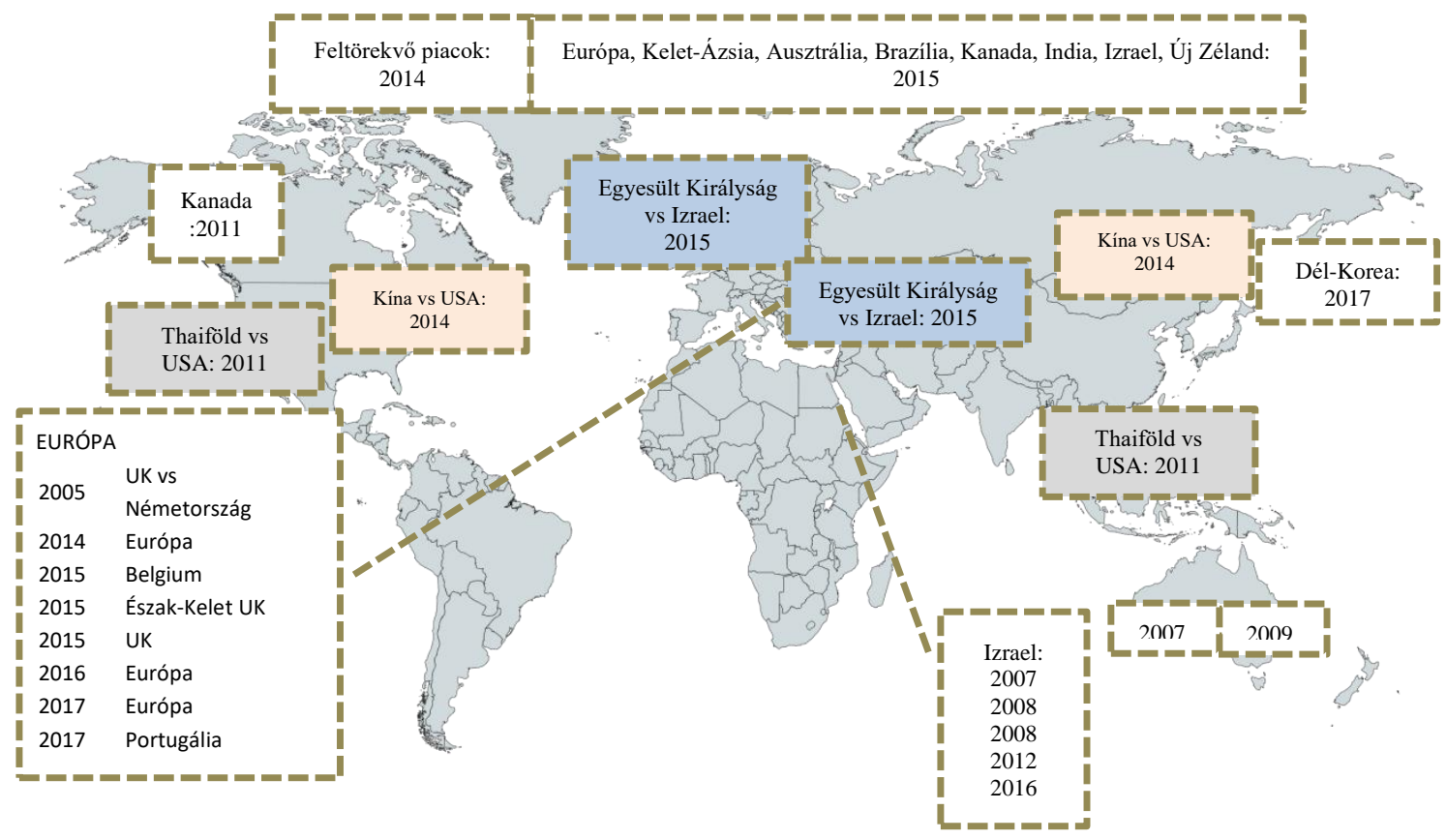

Forrás: saját szerkesztés

\subsection{A kutatási kérdések kapcsolata a vizsgált földrajzi területtel és időszakkal}

A tanulmányok kis mértékben eltérnek egymástól kutatási kérdéseiket tekintve, miközben mindegyik az állami beavatkozás optimális szintjét és módját keresi. Ezért következtetéseik hasznosak lehetnek a kutatók és a döntéshozók számára az egész világon. Ez az alfejezet a különböző kutatási kérdéseket vizsgálja, valamint azok kapcsolatát a vizsgált földrajzi területtel és időszakkal.

13. táblázat: Vizsgált földrajzi terület és időszak

\begin{tabular}{|c|c|c|c|}
\hline $\begin{array}{l}\text { Földrajzi } \\
\text { terület }\end{array}$ & Hivatkozás & Vizsgált földrajzi terület & Vizsgált időszak \\
\hline \multirow{4}{*}{ 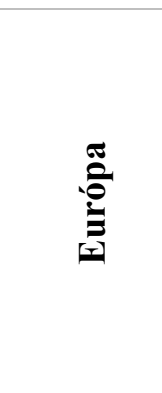 } & Heger et al. (2005) & $\begin{array}{l}\text { Egyesült Királyság vs. } \\
\text { Németország }\end{array}$ & $1990-2005$ \\
\hline & Cumming et al. (2017) & $\begin{array}{c}\text { Belgium, Finnország, } \\
\text { Franciaország, Németország, } \\
\text { Olaszország, Spanyolország, } \\
\text { Egyesült Királyság }\end{array}$ & $1991-2010$ \\
\hline & Guerini \& Quas (2016) & Európa & $1993-2010$ \\
\hline & Grilli \& Murtinu (2014) & Európai Unió & 1994-2011 \\
\hline
\end{tabular}




\begin{tabular}{|c|c|c|c|}
\hline $\begin{array}{c}\text { Földrajzi } \\
\text { terület }\end{array}$ & Hivatkozás & Vizsgált földrajzi terület & Vizsgált időszak \\
\hline & Alperovych et al. (2015) & Belgium & $1998-2007$ \\
\hline & Milosevic (2018) & Európa, Franciaország & $2005-2013$ \\
\hline & Karsai (2018) & Közép-Kelet-Európa térsége & $2007-2013$ \\
\hline & Bilau et al. (2017) & Portugália & $2008-2012$ \\
\hline & $\begin{array}{l}\text { Standaert \& Manigart } \\
\text { (2018) }\end{array}$ & Belgium & $2005-2009$ \\
\hline & Wray (2015) & Észak-Kelet-Anglia & 2012 \\
\hline & Baldoc \& Mason (2015) & Egyesült Királyság & $2000-2014$ \\
\hline & Gill (2015) & Egyesülg Királyság vs. Izrael & $1945-2014$ \\
\hline \multirow{5}{*}{$\overline{\mathbb{E}}$} & Avnimelech (2008) & Izrael & $1969-2005$ \\
\hline & Frenkel et al. (2008) & Izrael & $1990-2002$ \\
\hline & Wonglimpiyarat (2016) & Izrael & $1990-2012$ \\
\hline & Avnimelech et al. (2007) & Izrael & 1991-2004 \\
\hline & Cohen et al. (2012) & Izrael & $2000-2010$ \\
\hline \multirow{3}{*}{$\frac{\pi}{4}$} & Jung et al. (2017) & Dél-Korea & 2015 \\
\hline & Zhang (2014) & Kína vs. Egyesült Államok & $1997-2010$ \\
\hline & Wonglimpiyarat (2011) & Thaiföld, Egyesült Államok & 2010 \\
\hline \multirow{2}{*}{ Ausztrália } & Cumming \& Johan (2009) & Ausztrália & $1982-2005$ \\
\hline & Cumming (2007) & Ausztrália & $1982-2005$ \\
\hline Kanada & Tucker et al. (2011) & Kanada & $2001-2010$ \\
\hline \multirow[b]{2}{*}{ Globális } & Brander et al (2015) & globális & $2000-2012$ \\
\hline & $\begin{array}{l}\text { Herrera-Echeverri et al. } \\
\text { (2014) }\end{array}$ & feltörekvő piacok & $1996-2010$ \\
\hline Elméleti & Bauer \& Burghof (2007) & - & - \\
\hline
\end{tabular}

Forrás: saját szerkesztés

\subsubsection{Európa}

Tizenkét cikk tanulmányozta az európai régiót. Az Egyesült Királyság állami szerepét a korai fázisú tőkebefektetésben számos írás tanulmányozta. Az adatbázisunk legkorábbi publikációja Heger és szerzőtársai (2005) munkája, akik az Egyesült Királyság és Németország állami forrásnyújtását vizsgálták 1990 és 2005 között. Az Egyesült Királyság állami beavatkozásait több kutató is vizsgálta. Gill (2015) az Egyesült Királyság kockázatitőke-szektor újjáépítéséhez szükséges legfontosabb állami intézkedéseket határozta meg, elemezte 1945-2014 közötti állami beavatkozásokat, és követendő példának az izraeli Yozma programot jelölte meg. A vizsgálat aktualitását a British Business Bank nemrégiben történt létrehozása adta, amely európai uniós állami támogatást kapott a korai stádiumú kockázati tőke előmozdítása érdekében. Baldock and Mason (2015) szintén az Egyesült Királyság állami programjainak hatékonyságát vizsgálták 2000-2014 között. Wray (2015) 
három folyamat kibontakozására volt kíváncsi az Egyesült Királyságban 2012-ben: az állami átméretezésre, a recessziós állapotokra, illetve az üzleteket támogató reformokra.

Számos európai régiót vizsgáló cikk feltette a kérdést, hogy az állami kockázati tőke és a magán kockázati tőke partnerségi kezdeményezései hatékonynak bizonyultak-e vagy sem, de adataikat különböző földrajzi helyekröl szerezték be, és a sikert eltérően definiálták. Standaert és szerzőtársai (2018) azt kívánták megtudni, hogy az állam elérte-e célját Belgiumban az állami kockázati tőke és a magánpiaci kockázati tőke partnersége révén, amelynek célja a céltársaságok foglalkoztatásának növekedése volt a 2005 októbere és 2009 decembere közötti időszakban. Karsait (2018) a közép-kelet-európai állami kockázati tőke és magán kockázati tőkeprogramok minősége érdekelte, amelyeket az EU finanszírozott 2007 és 2013 között.

A cikkek egy csoportja közvetlenül az állami kockázati tőkét és a tisztán magán kockázati tőkefinanszírozást kívánta összehasonlítani a hatékonyság szempontjából, de szintén különböző földrajzi területen és különböző módszerek alkalmazásával. Grilli és Murtinu (2014) a VICO adatbázist felhasználva szerették volna összehasonlítani az állami kockázati tőkét és a magánpiaci kockázati tőkebefektetéseket 1994 és 2011 között az EU-ban a céltársaságok árbevételének és foglalkoztatásának növekedésére gyakorolt hatás szempontjából. Cumming (2017) nagyon hasonló tanulmányt készített ugyanezen adathalmazból az 1991-2010-es periódust kutatva, azonban ő a céltársaságok exitlehetőségeit is megvizsgálta. Ugyanezt az adathalmazt 1993 és 2010 között vizsgálva Guerini és Quas (2016) az állami kockázati tőke és a magán kockázati tőke közötti különbségre helyezte a hangsúlyt az EU-beli célválasztási képességek tekintetében. Alperovych és szerzőtársai (2015) a sikert termelékenységként definiálták, és a belga állami kockázati tőke és a magánpiaci kockázati tőke befektetési céljait vizsgálták 1998 és 2007 között.

Vannak olyan tanulmányok, amelyek specifikus problémákat vizsgáltak egy bizonyos európai országban. Bilau és szerzőtársai (2017) célja annak feltárása volt, hogy az üzleti angyalok gazdasági válság alatt is folytatják-e befektetéseiket, valamint, hogy mennyire voltak sikeresek Portugália jogszabályai az angyalbefektetések népszerúsítésének tekintetében a 2008 és 2012 közötti kritikus időszakban. Milosevic (2018) arra kívánt rájönni, hogy a kockázati tőkemenedzserek 
társadalmi tőkéje hogyan hat céltársaságok sikerére. Ö Franciaországra és a 20052013-as időszakra összpontosított.

\subsubsection{Izrael}

Hat cikk tanulmányozta az izraeli kockázati tőkepiacot. Frenkel és szerzőtársai (2008) az alapvető különbségeket kutatta az állami és magán technológiai inkubátorok tulajdonságai között az országban 1990 és 2002 között. Cohen és szerzőtársai (2012) az izraeli OCS programokat értékelték, illetve azok fejlődését 2000 és 2010 között, míg Avnimelech (2008) az innovációs és technológiai törvényhozás 1969 és 2005 közötti evolúcióját mutatták be. Később Avnimelech és szerzőtársai (2007) a kockázati tőkés és technológiai inkubációs támogatás az izraeli startupok fejlődésére és hatékonyságára gyakorolt hatását kutatták 1991 és 2004 között. Gill (2015) az UK Business Bank strukturált kockázati tőkefinanszírozási tevékenységét részben az izraeli Yozma modellhez hasonlította, azonban Frenkel és szerzőtársai (2008) és Cohen és szerzőtársai (2012) hivatkozása nélkül, akik az izraeli kockázati tőkepiacot és állami irányelveket mutatták be. Wonglimpiyarat (2016) szintén Izraelt vizsgálja 1990 és 2012 között, különös figyelemmel arra, hogy az állami erőfeszítések hogyan segítették az ökoszisztéma fejlődését és a kockázati tőkeipart.

Ezen cikkek alapján széleskörü rálátást kapunk az 1969-2010 közötti a kockázati tőkeipart támogató izraeli állami programokra, amelyeket a szerzők sikeres példáknak tartják. Gill (2015) az izraeli modellt hasznosnak és sikeresnek tartja, amelyet érdemes követnie az Egyesült Királyság államának is.

\subsection{3 Ázsia}

Három tanulmány foglalkozik ázsiai országok (Kína, Dél-Korea és Thaiföld) kockázati tőkepiacával. Két munka hasonlított össze állami intézkedéseket. Zhang (2014) az SCLC-k céges kormányzását térképezi fel az adaptív hatékonyság szempontjából 1997-2010 között. Megállította, hogy az amerikai modell sikeresnek bizonyult a külső innováció előmozdítása szempontjából. Wonglimpiyarat (2011) Thaiföld intézményi környezetének, pénzügyi innovációs rendszerének, innovációs finanszírozási politikájának és technológiai finanszírozási mechanizmusának az innovációs kapacitásra, innovációs eredményekre és a cégek innovatív vállalkozási képességére gyakorolt hatásait vizsgálta 2010-ben. Megállapította, hogy az amerikai Szilícium-völgy modell ideális intézményi keretrendszer. Azt állította, hogy az 
államnak támogatni kellene a csúcstechnológiás startupokat azzal, hogy finanszírozási ösztönzőket biztosít kölcsönök, részvények, pályázati támogatások és adókedvezmények formájában.

A harmadik tanulmány Jung és szerzőtársai (2017) tollából a dél-koreai Kreatív Gazdasági és Innovációs Központok különböző érintettjeinek nézőpontjaira fókuszál. Ez a három cikk betekintés nyújt három ázsiai ország kockázati tőkepiacára, illetve a kockázati tőkebefektetésekkel kapcsolatos egyedi problémáikra.

\subsubsection{Ausztrália}

Két cikk tanulmányozta az ausztrál kockázati tőkepiacot. Az európai piacot vizsgáló tanulmányokhoz hasonlóan ezek a cikkek is azt a kérdést teszik fel, hogy az állami és a magán kockázati tőke partnerségi kezdeményezései hatékonynak bizonyultak-e vagy sem. Cumming (2007) azt kívánja feltárni, hogy Ausztrália állami és magán kockázati tökeprogramja sikeres volt-e más kockázati tőkealapokhoz képest. Cumming és Johan (2009) a korai fázisú ausztrál állami kockázati tőke és magán kockázati tőke partnerségi programjának sikerét hasonlította össze más állami programokkal. Ez a két cikk földrajzi értelemben kibővíti ismereteinket az állami és a magánszektor partnerségének hatékonyságáról, amelyek célja, hogy a fiatal vállalkozók sikert érjenek el a kockázati tőkepiacon.

\subsubsection{Kanada, Amerikai Egyesült Államok, Globális szint}

Egy tanulmány vizsgálta a kanadai államot és kettő szélesebb földrajzi területet fedett le. Tucker és szerzőtársai (2011) arra voltak kíváncsiak, hogy milyen strukturális problémák merülnek fel az élettudományi szektor alulteljesítésében az egyébként jól teljesítő kanadai kockázati tőkeiparban. Az Amerikai Egyesült Államok kockázati tőkemodellje több tanulmányban példaértékűként volt említve (Zhang, 2014; Wonglimpiyarat, 2011). Herrera-Echeverri és munkatársai (2014) azt nézték meg, hogy a különböző makro szintü változók és az állami beavatkozás hogyan hat a kockázati tőke aktivitására feltörekvő országokban. Brander és szerzőtársai (2015) világszintü adathalmazon vizsgálták az állami kockázati tőke és a magán kockázati tőke befektetéseit az exitlehetőségek tekintetében.

Bauer and Burghof (2007) egy elméleti tanulmányt írt, amely nem egy specifikus földrajzi régióra összpontosít. A tanulmány nem használt empirikus elemzést vagy adatokat a modell tesztelésére. Azt vizsgálták elméleti síkon, hogy az államnak hogyan kellene elköltenie a pénzét, hogy a lehető legnagyobb mennyiségü 
hozzáadott magánbefektetést generálja. Ennek érdekében kétperiódusú befektetési modellben elemezték az állami támogatások hatását a kezdeti fázisú befektetésekre.

\subsection{A tartalomelemzés eredménye}

A tartalomelemzéssel összegyüjtöttük és rendszereztük a megfigyeléseket és megállapításokat az állam szerepéről a korai fázisú kockázati finanszírozási piacon. Az in-vivo kódok az állam beavatkozásának típusát meghatározó témák (tisztán állami kockázati tőke, az állami és magán kockázati tőke partnersége, az államilag támogatott magvető előtti fázisú finanszírozás, illetve az ajánlások) szerint lettek csoportosítva. A megállapítások a fö témák szerint lesznek bemutatva, amelyek tovább vannak bontva aszerint altémákra, hogy a megállapítás pozitív vagy negatív tartalmú-e. Az eredmények bemutatása a téma tulajdonságainak magyarázatával kezdődik. Ennek a résznek a célja, hogy bemutassa a kutatók értékelését az állami beavatkozási típusokról (5-9. kutatási kérdések).

\subsubsection{Tisztán állami kockázati töke (közvetlen beavatkozás)}

Az egyik legközvetlenebb állami beavatkozási típus a kockázati tőkepiacon, ha az állam saját alapkezelőt hoz létre, amely állam által biztosított forrásokat kezel. Ezt hívjuk tisztán állami kockázati tőkének, mivel nem szerepel benne magánszereplő az állam kezeli saját alapját. 24 in-vivo kód értékeli pozitívan a tisztán állami beavatkozást, és 24 negatívan. Igen heves vita övezi az állami beavatkozás ezen formáját, és nagy eltérések vannak az eredmények között a földrajzi tekintetben.

A 14. táblázat tartalmazza azon kategóriákat, amelyek a tisztán állami kockázati tőke pozitív megnyilvánulásait mutatják. A témát elemző 19 cikkből 10 adott pozitív értékeléseket. Az EU-t vizsgáló tanulmányok értékelése a tisztán állami kockázati tőkés kezdeményezésekről vegyes, míg az izraeli, egyesült államokbeli, thaiföldi és dél-koreai eredmények egyöntetüen pozitívak.

14. táblázat: A tisztán állami kockázati tőke pozitív megnyilvánulásai

\begin{tabular}{|c|c|c|c|}
\hline $\begin{array}{c}\text { Felhasznált releváns } \\
\text { forrás }\end{array}$ & Kategória & $\begin{array}{c}\text { In-vivo kódok } \\
\text { száma }\end{array}$ & Földrajzi terület \\
\hline $\begin{array}{l}\text { Bauer, Burghof (2007); } \\
\text { Wonglimpiyarat } \\
\text { (2011); Cohen, Gabbay, }\end{array}$ & $\begin{array}{l}\text { Az állami kockázati tőke } \\
\text { kiegészíti a magán } \\
\text { kockázati tőkét }\end{array}$ & $e_{1}$ & $\begin{array}{l}\text { Izrael, Egyesült } \\
\text { Királyság, EU }\end{array}$ \\
\hline $\begin{array}{l}\text { Schiffman (2012); } \\
\text { Jung, Eun, Lee (2017); } \\
\text { Baldock, Mason (2015); }\end{array}$ & $\begin{array}{l}\text { Az állami kockázati tőke } \\
\text { előmozdítja a magán } \\
\text { kockázati tőkeszerzést }\end{array}$ & 6 & EU \\
\hline
\end{tabular}




\begin{tabular}{|l|l|c|c|}
\hline $\begin{array}{c}\text { Felhasznált releváns } \\
\text { forrás }\end{array}$ & \multicolumn{1}{|c|}{ Kategória } & $\begin{array}{c}\text { In-vivo kódok } \\
\text { száma }\end{array}$ & Földrajzi terület \\
\hline $\begin{array}{c}\text { Brander, et al. (2015); } \\
\text { Wonglimpiyarat } \\
\text { (2016); Karsai (2018); } \\
\text { Guerini, Quas (2016) }\end{array}$ & $\begin{array}{l}\text { Az állami kockázati tőke } \\
\text { ösztönzi a gazdaságot }\end{array}$ & 3 & $\begin{array}{c}\text { Thaiföld, } \\
\text { Egyesült } \\
\text { Államok, } \\
\text { Egyesült } \\
\text { Királyság }\end{array}$ \\
\hline & $\begin{array}{l}\text { Az állami kockázati tőke } \\
\text { nem szorítja ki a magán } \\
\text { kockázati tőkét }\end{array}$ & 2 & $\begin{array}{c}\text { Izrael, Közép- } \\
\text { Kelet-Európa }\end{array}$ \\
\hline & $\begin{array}{l}\text { Az állami kockázati tőke } \\
\text { betölti a finanszírozási } \\
\text { rést }\end{array}$ & 2 & $\begin{array}{c}\text { Thaiföld, } \\
\text { Egyesült Államok }\end{array}$ \\
\hline $\begin{array}{ll}\text { Az állami kockázati tőke } \\
\text { segíti a gazdaságból való } \\
\text { kilábalást }\end{array}$ & 2 & $\begin{array}{c}\text { Egyesült } \\
\text { Királyság }\end{array}$ \\
\hline & $\begin{array}{l}\text { Az állami kockázati tőke } \\
\text { hatékony }\end{array}$ & 2 & Európa \\
\hline & $\begin{array}{l}\text { Az állami kockázati tőke } \\
\text { cselekvésre bírja és } \\
\text { élénkíti a } \\
\text { magánszereplóket }\end{array}$ & 1 & Dél-Korea \\
\hline ÖsszESEN & $\mathbf{2 4}$ & \\
\hline
\end{tabular}

Forrás: saját szerkesztés

A cikkek egy csoportja az állami kockázati tőkéröl megállapította, hogy kiegészíti a magán kockázati tőkét. Cohen, Gabbay és Schiffman (2012) azt állapították meg, hogy a $\mathrm{K}+\mathrm{F}$ állami finanszírozása kiegészíti a magán kockázati tőkefinanszírozást az izraeli csúcstechnológiai iparban, és ezzel kapcsolatban erős a konszenzus. Baldock and Mason (2015) az Egyesült Királyság államának kockázati tőkés erőfeszítéseit vizsgálta, és azt állapították meg, hogy kiegészíti a magán kockázati tőkés finanszírozást. Ezen kívül azt is konstatálták, hogy az állami kockázati tőke munkahelyteremtéssel élénkítette az ország gazdaságát. Végül Brander és szerzőtársai (2015) nemzetközi adathalmazon állapították meg azt, hogy az állami kockázati tőkefinanszírozás növeli a cégek számára elérhető teljes kockázati tőke mennyiségét, így nincs kiszorító hatás. Szerintük sok állami kockázati tőkét elnyerő startup magán kockázati tőkét egyáltalán nem is kaphatott volna. Ez arra is utalhat, hogy az állami kockázati tőke betölti a finanszírozási rést. Azt is megállapították, hogy míg a tisztán állami kockázati tőkebefektetésnek szerény az exitteljesítménye az Egyesült Államokban, Európában az ellenkezőre találtak bizonyítékot. Másrészt Karsai (2018) szerint az az oka annak, hogy az állami 
kockázati tőkebefektetések nem szorították ki a magán kockázati tőkebefektetéseket a közép-kelet-európai piacon, hogy eleve hiány van magánbefektetőkből a régióban.

Elméleti elemzés alapján Bauer és Burghof (2007) bebizonyították, hogy az állami beavatkozás akkor a leghatásosabb, ha minimális állami pénzmennyiség felhasználása mellett a magántőke mobilizálja, a szerepe tehát lényegében a magán kockázati tőkeszerzés elősegítése. Wonglimpiyarat (2016) azt is megállapította, hogy az állami kockázati tőkebefektetés Izraelben nem kiszorította, hanem motiválta a magánbefektetéseknek. Guerini és Quas (2016) tanulmányuk alapján hatékonynak találták az állami kockázati tőkét, mivel az állami kockázati tőkefinanszírozás növelte annak az esélyét, hogy a cégek magán kockázati tőkét szerezzenek. Ezért úgy gondolták, hogy az állami kockázati tőkebefektetők jól választották ki a célbefektetéseket, és csökkentették az információs aszimmetriát a magán tőkefinanszírozási bírálati folyamatában.

Wonglimpiyarat (2011) szerint az amerikai piacon végrehajtott befektetések alapján az állami beavatkozás serkentheti a gazdaságot. Megállapította, hogy az Egyesült Államok állami finanszírozási programjai javítják az Egyesült Államok gazdasági teljesítményét, illetve rövid és hosszú távon betöltik az innovatív projektek finanszírozási rését, különösen az innovációs életciklus elején. Jung és szerzőtársai (2017) úgy vélik, hogy az állami kockázati tőke fő szerepe a dél-koreai startup ökoszisztéma fejlődésének ösztönzése.

Két olyan cikk található, amelyek szerint az állami kockázati tőke kiszorítja a magán kockázati tőkét, az egyikük tette a megállapítást empirikus elemzés alapján: egy, a feltörekvő piacokkal kapcsolatos adatbázis felhasználásával Herrera-Echeverri és szerzőtársai (2014) megállapították, hogy az állami kiadások - ideértve az állami kockázati tőkét is - negatívan befolyásolják a magán kockázati tőke tevékenységét, és az állam számára a kockázatitőke-szektor támogatásának legjobb módja az intézményi minőség javítása és a kiadások csökkentése. Bauer és Burghof (2007) elméleti modellt épített, amely jelezte, hogy a nagy mértékü állami beavatkozás kiszoríthatja a magánpénzeket. Milosevic (2018) képviseleti problémákat is talált az állami kockázati tőkével kapcsolatban Franciaországban.

Ezen kívül jelentős nemzetközi bizonyíték áll rendelkezésre arról, hogy az állami kockázati tőke kevésbé hatékony, mint a magán kockázati tőke. Tucker és szerzőtársai (2011) a kanadai állami kockázati tőkebefektetések gyenge megtérülését említi annak okaként, hogy csak minimális állami részvételt kéne fenntartani, és 
hogy nagyrészt át kéne térni a magán kockázati tőkefinanszírozásra. Azt is hozzáteszik, hogy a kanadai állami kockázati tőkebefektetések bár nem hatékonyak, így is hozzájárultak az élettudományi ipari aktivitás kritikus tömegének létrehozásához. Az európai adatok is alátámasztják, hogy a magán kockázati tőkebefektetést szerző társaságok jobb exitlehetőségekkel rendelkeznek, mint az állami kockázati tőkebefektetést szerzők (Cumming et al., 2017). Alperovych és szerzőtársai (2015) hasonlóan azt állapították meg, hogy a belga állami kockázati tőkebefektetések jelentős negatív hatással vannak a megcélzott vállalatok termelékenységére. Grilli és Murtinu (2014) azt találták, hogy az állami kockázati tőkefinanszírozás az EU-ban nem képes előmozdítani a céltársaságok értékesítésének növekedését, mert az állami kockázati tőkebefektetők nem rendelkeztek hozzáadott értékkel bíró képességekkel. Cumming és Johan (2009) az ausztrál állami kockázati tőkeprogramokat is kritizálják, mert azok vegyes teljesítményt mutatnak a nyújtott finanszírozást és az irányítást tekintve.

Az exit-teljesítményt szintén a hatékonyság hiányának jeleként értékelték Brander és szerzőtársai (2015), akik negatív összefüggést találtak az exitteljesítmény és az állami kockázati tőkefinanszírozás között az Egyesült Államokban. Standaert és Manigart (2018) szerint Belgiumban az állami kockázati tőkebefektetők rosszabbul választják ki a leendő befektetéseket, mint a magán kockázati tőkebefektetők; ezért azt javasolják, hogy az állami kockázati tőkebefektetők hagyják a magán kockázati tőkebefektetőket számukra célvállalatokat kiválasztani (állami kockázati tőke és magán kockázati tőke partnersége), ami nagyobb növekedést eredményezne a foglalkoztatottságban. Összegzésképpen elmondható, hogy a közvetlen beavatkozás megítélése vegyes a szakirodalomban, ezért a $2 b$ propozíció - „A cikkek elsősorban negatív hatásokat társítanak a közvetlen állami beavatkozáshoz" - nem talált támogatásra, mivel az szakirodalom nem társít főként negatív hatásokat az állami beavatkozáshoz.

15. táblázat: A tisztán állami kockázati tőke negatív megnyilvánulásai

\begin{tabular}{|c|l|c|c|}
\hline $\begin{array}{c}\text { Felhasznált releváns } \\
\text { forrás }\end{array}$ & \multicolumn{1}{|c|}{ Kategória } & $\begin{array}{c}\text { In-vivo } \\
\text { kódok száma }\end{array}$ & Földrajzi terület \\
\hline $\begin{array}{c}\text { Alperovych, Hübner, } \\
\text { Lobet (2015); Brander, et } \\
\text { al. (2015); Cumming, } \\
\text { Grilli, Murtinu (2017); }\end{array}$ & $\begin{array}{l}\text { Az állami kockázati tőke } \\
\text { kiszorítja a magán kockázati } \\
\text { tőkét }\end{array}$ & $\begin{array}{l}\text { Az állami kockázati tőke } \\
\text { feltörekvő piacok }\end{array}$ & 5 \\
\hline
\end{tabular}




\begin{tabular}{|c|c|c|c|}
\hline $\begin{array}{c}\text { Felhasznált releváns } \\
\text { forrás }\end{array}$ & Kategória & $\begin{array}{c}\text { In-vivo } \\
\text { kódok száma }\end{array}$ & Földrajzi terület \\
\hline \multirow{7}{*}{$\begin{array}{l}\text { Grilli, Murtinu (2014); } \\
\text { Herrera-Echeverri, } \\
\text { Haar, Estevez-Bretón } \\
\text { (2014); Karsai (2018); } \\
\text { Milosevic (2018); } \\
\text { Standaert, Manigart } \\
\text { (2018); Tucker, Chakma, } \\
\text { Fedak, Cimini (2011); } \\
\text { Bauer, Burghof (2007) }\end{array}$} & ügynökproblémákkal jár & & \\
\hline & $\begin{array}{l}\text { Az állami kockázati tőke } \\
\text { kevésbé hatékony, mint a } \\
\text { magán kockázati tőke }\end{array}$ & 5 & $\begin{array}{l}\text { Kanada, Európa, } \\
\text { Belgium }\end{array}$ \\
\hline & $\begin{array}{l}\text { Az állami kockázati tôke nem } \\
\text { képes elég hatékonyan } \\
\text { támogatni a céltársaságokat }\end{array}$ & 4 & EU, Belgium \\
\hline & $\begin{array}{l}\text { Az állami kockázati tőke nem } \\
\text { hatékony }\end{array}$ & 4 & $\begin{array}{l}\text { Egyesült Államok, } \\
\text { Kanada, Közép- } \\
\text { Kelet-Európa, } \\
\text { Ausztrália }\end{array}$ \\
\hline & $\begin{array}{l}\text { Az állami kockázati tőke } \\
\text { rosszabbul választ ki, mint a } \\
\text { magán kockázati tőke }\end{array}$ & 4 & Belgium \\
\hline & $\begin{array}{l}\text { Az állami kockázati tőke hatása } \\
\text { önmagában elhanyagolható }\end{array}$ & 1 & EU \\
\hline & ÖSSZESEN & 24 & \\
\hline
\end{tabular}

Forrás: saját szerkesztés

\subsubsection{Az állami kockázati tőke és a magán kockázati tőke partnersége}

$\mathrm{Az}$ állam a startup cégek finanszírozásakor két fó módon tud partneri kapcsolatba lépni a magánszereplőkkel. Az egyik az, hogy állam pénzügyi forrást biztosít, amelyet teljes egészében a magán kockázati tőkealap-kezelő kezel (hibrid finanszírozás, közvetett beavatkozás). Még ez a partneri kapcsolat is általában megkívánja, hogy a magán kockázati tőkés partner biztosítsa a kezelt források egy részét. Előfordul, hogy az állam a befektetési döntési folyamatban képviselteti magát a privát tőkealap-kezelőben, jellemzően testületekbe delegál, vagy jelöl tagot, hogy így kontrollálja a befektetéseket. A másik fő módja az állami-magán partnerségnek, hogy a startup céltársaság befektetést kap magán és állami kockázati tőkésektől is. Ez történhet egyszerre (társbefektetés - „co-investment”), vagy időben eltolva. Az elemzett szakirodalom mindezen partnerségi típusok példáit vizsgálja, az eredmények pozitív és negatív értékelési bontásban kerülnek bemutatásra.

Számos cikk állapította meg, hogy az állami kockázati tőke kiegészíti a magán kockázati tőkét. Grilli és Murtinu (2014) EU-s adatok vizsgálatával arra a következtetésre jutott, hogy az állami beavatkozás csak akkor lehet pozitív hatással a cég növekedésére állami és magán kockázati tőkés partneri befektetés esetében, ha a magánbefektető a fontosabb partner a szindikátusban. Szerintük az ausztrál IIF-ek közös befektetési modellje (co-investment) hatásos megközelítés. Ellenben világszintü nemzetközi adatokat használva Brander és szerzőtársai (2015) 
leszögezték, hogy az állami befektetők jelenléte ezekben a partnerségekben segítheti a potenciális portfóliócégek kiválasztását a tisztán állami kockázati tőkebefektetéshez képest.

Van a cikkeknek egy olyan csoportja is, amely megállapította, hogy az ilyen partnerség által megvalósított befektetések pozitívabb hatással vannak a portfóliótársaságokra, mint a kizárólag állami kockázati tőke vagy magán kockázati tőkebefektetések. Standaert és Manigart (2018) a foglalkoztatás nagyobb növekedéseként figyelték meg ezt a pozitív hatást Belgiumban. Az EU adatainak felhasználásával Cumming és szerzőtársai (2017) azt állapították meg, hogy ez a pozitív hatás az exit nagyobb valószínüsége. Ezt Brander és szerzőtársai (2015) is alátámasztják, akik nemzetközi adathalmazt vizsgáltak és azt is leszögezték, hogy az állami és magán kockázati tőkés partnerség által finanszírozott vállalkozások nagyobb tőkefinanszírozásra tesznek szert, mint a tisztán államilag vagy tisztán magántőke által finanszírozottak. Továbbá, hogy az állami partnernek inkább a pénzügyi számokra kell hangsúlyt fektetnie a portfóliócég kiválasztásakor, mint az externáliákra.

Gill (2015) megállapította, hogy az állam beavatkozása jelentős mértékben fejlődött az Egyesült Királyságban az úgynevezett „hibrid köz-magán” forma tekintetében. A javulás megfigyelhető a programok tervezésében és célzottságában, valamint a helyi beruházások költséghatékonyságában.

16. táblázat: Az állami és magán partnerségü kockázati tőke pozitív megnyilvánulásai

\begin{tabular}{|c|c|c|c|}
\hline $\begin{array}{l}\text { Felhasznált } \\
\text { releváns forrás }\end{array}$ & Kategória & $\begin{array}{l}\text { In-vivo } \\
\text { kódok } \\
\text { száma }\end{array}$ & $\begin{array}{l}\text { Földrajzi } \\
\text { terület }\end{array}$ \\
\hline \multirow{4}{*}{$\begin{array}{c}\text { Grilli, Murtinu } \\
\text { (2014); } \\
\text { Brander, et al. } \\
\text { (2015); } \\
\text { Standaert, } \\
\text { Manigart } \\
(2018) ; \text { Gill } \\
\text { (2015); } \\
\text { Cumming et al. } \\
\text { (2017) }\end{array}$} & $\begin{array}{l}\text { Az állami kockázati tőke kiegészíti a } \\
\text { magán kockázati tőkét }\end{array}$ & 4 & $\begin{array}{l}\text { Egyesült } \\
\text { Királyság, } \\
\text { globális }\end{array}$ \\
\hline & $\begin{array}{l}\text { Az állami és magán partnerségú } \\
\text { kockázati tőke forrásait jobban } \\
\text { kezelik a magánszereplők }\end{array}$ & 2 & EU \\
\hline & $\begin{array}{l}\text { Az állami és magán partnerségű } \\
\text { kockázati tőke jobb kiválasztási } \\
\text { kritériumokkal rendelkezik, mint a } \\
\text { magán kockázati tőke }\end{array}$ & 1 & globális \\
\hline & $\begin{array}{l}\text { Az állami és magán partnerségú } \\
\text { kockázati tőke nagyobb pozitív } \\
\text { hatással bír, mint a tisztán állami }\end{array}$ & 8 & $\begin{array}{l}\text { Belgium, } \\
\text { Európa, } \\
\text { globális }\end{array}$ \\
\hline
\end{tabular}




\begin{tabular}{|l|l|c|c|}
\hline & vagy a tisztán magán kockázati tőke & & \\
\hline $\begin{array}{l}\text { Az állami és magán partnerségű } \\
\text { kockázati tőke kiválasztási } \\
\text { kritériumai a pénzügyi számokon } \\
\text { alapulnak }\end{array}$ & 1 & globális \\
\hline $\begin{array}{l}\text { Az állami és magán partnerségű } \\
\text { kockázati tőke segíti a kockázati } \\
\text { tőkeipar fejlődését }\end{array}$ & 1 & EU \\
\hline \begin{tabular}{l} 
ÖSSZESEN \\
\hline
\end{tabular} & 17 & \\
\hline
\end{tabular}

Forrás: saját szerkesztés

Karsai (2018) figyelmeztet az állami kockázati tőkefinanszírozásban jelen lévő ügynökproblémákra a közép-kelet-európai régióban. Továbbá túlszabályozottság miatt kritizálta az EU állami és magán kockázati tőkés partnerségi programjait. Ehhez hozzájáruló tényezőkként a hosszú felállítási időtartamokat és az alapok elégtelen méretét említette. Kritikával illette a programokat irányító hatóságokat is, mivel azok nem érvényesíttették a résztvevő alapkezelőkre vonatkozó szabályokat, és nem kezdeményeztek alapos kiértékeléseket a programok befejezte után. Véleménye szerint ezenkívül a programok rövid időkerete elhamarkodott befektetési döntésekhez vezet a viszonylag tapasztalatlan alapkezelők részéről, illetve kihelyezési nyomáshoz is. Ausztrál adatok alapján Cumming és Johan (2009) rámutat arra is, hogy az állami kockázatitőke-programok fö kihívása az alapkezelök kiválasztása.

Jung és munkatársai (2017) bírálták a dél-koreai bürokratikus akadályokat is, amelyek gátolják az állami kockázati tőke és a magán kockázati tőkebefektetők közötti hatékony együttmüködést. Gill (2015) az állami és magán partnerségü kockázati tőke nem hatékony müködésére talált bizonyítékot, mivel a kínálat és a kereslet közötti eltérések még mindig jelentős alternatívaköltségeket okoznak az Egyesült Királyság gazdaságának. Összefoglalva, a vizsgált cikkek az állami-privát partnerségű kockázati tőkéhez valamivel több pozitív, mint negatív hatást társítottak, így a 2 c propozíció - A cikkek pozitiv és negativ hatásokat egyformán társítanak az állami-privát partnerségü kockázati tőkéhez - részben támogatásra talált.

17. táblázat: Az állami és magán partnerségü kockázati tőke negatív megnyilvánulásai

\begin{tabular}{c|c|c|c|}
$\begin{array}{c}\text { Felhasznált } \\
\text { releváns } \\
\text { forrás }\end{array}$ & Kategória & $\begin{array}{c}\text { In-vivo } \\
\text { kódok } \\
\text { száma }\end{array}$ & $\begin{array}{r}\text { Földrajzi } \\
\text { terület }\end{array}$ \\
\hline
\end{tabular}




\begin{tabular}{|c|c|c|c|}
\hline \multirow{8}{*}{$\begin{array}{c}\text { Jung, Eun, } \\
\text { Lee (2017); } \\
\text { Karsai (2018); } \\
\text { Gill (2015); } \\
\text { Cumming, } \\
\text { Johan (2009) }\end{array}$} & $\begin{array}{l}\text { Az állami és magán partnerségü kockázati } \\
\text { tőkeprogramok ügynökproblémától } \\
\text { szenvednek }\end{array}$ & 2 & $\begin{array}{l}\text { Közép-Kelet- } \\
\text { Európa, } \\
\text { Ausztrália }\end{array}$ \\
\hline & $\begin{array}{l}\text { Az állami és magán partnerségú kockázati } \\
\text { tőkeprogramok nagymértékben } \\
\text { túlszabályozottak }\end{array}$ & 3 & $\begin{array}{l}\text { Közép-Kelet- } \\
\text { Európa }\end{array}$ \\
\hline & $\begin{array}{l}\text { Az állami és magán partnerségú kockázati } \\
\text { tőkeprogramokból hiányzik a felügyelet }\end{array}$ & 2 & $\begin{array}{l}\text { Közép-Kelet- } \\
\text { Európa }\end{array}$ \\
\hline & $\begin{array}{l}\text { Az állami és magán partnerségű kockázati } \\
\text { tőkeprogramok kihelyezési nyomástól } \\
\text { szenvednek }\end{array}$ & 1 & $\begin{array}{l}\text { Közép-Kelet- } \\
\text { Európa }\end{array}$ \\
\hline & $\begin{array}{l}\text { Az állami-magán kockázati tőke esetében a } \\
\text { magán tőkealap-kezelők tapasztalatlanok }\end{array}$ & 1 & $\begin{array}{l}\text { Közép-Kelet- } \\
\text { Európa }\end{array}$ \\
\hline & $\begin{array}{l}\text { Az állami-magán kockázati tőkés } \\
\text { együttműködés problémás }\end{array}$ & 1 & Dél-Korea \\
\hline & $\begin{array}{l}\text { Az állami-magán kockázati tőke nem } \\
\text { hatékony }\end{array}$ & 2 & $\begin{array}{l}\text { Egyesült } \\
\text { Királyság }\end{array}$ \\
\hline & ÖSSZESEN & 12 & \\
\hline
\end{tabular}

Forrás: saját szerkesztés

\subsubsection{Az állami kockázati tőke beavatkozásaz inkubációs fázisú finanszírozásban}

Az inkubációs fázis („pre-seed”) a startupok finanszírozásának speciális esete, mivel ezek a befektetések hordozzák a legnagyobb kockázatot annak köszönhetően, hogy a cég ebben a fázisban csak egy ötletet tudhat magáénak. Az államok általánosságban úgy célozzák meg ezt a fázist, hogy inkubátoroknak és üzleti angyaloknak biztosítanak anyagi támogatást. Mivel ez a téma külön lett azonosítva a kockázati tőkés beavatkozással kapcsolatos témák mellett, a $2 a$ propozíció - „A cikkek elsősorban a kockázati tökepiac állami beavatkozásának közvetlen és a privát szektorral partnerségben végrehajtott formáját vizsgálják" - részben támogatásra talált, hiszen a cikkek többsége valóban a kockázati tőkés közvetlen és a privát szektorral partnerségben végrehajtott formáját vizsgálják, ám egy kisebb részük az inkubációs fázis kezdeményezéseit vizsgálta. Ebben a szekcióban az lesz bemutatva, hogy ezeket a kezdeményezéseket a szakirodalom sikeresnek értékeli-e vagy sem.

A tartalomelemzés alapján 34 gondolati egységet azonosítottunk, amelyek pozitívan értékelték az állami intervenciót, és csak két negatív gondolati egységet. Az inkubációs fázisú startupoknak nincs múltjuk, így sokkal kockázatosabb ezekbe fektetni, mint a későbbi fázisúakba. Ez a pénzügyi információhiány vezet az aszimmetrikus információ piaci kudarcához. Így az állam beavatkozása az inkubációs fázisban a leginkább indokolt. 
A 26 szerző közül hat adott pozitív visszajelzést az állami kockázati tőke beavatkozásával kapcsolatban az inkubációs finanszírozási fázisban. Ezek négy kategóriába lettek csoportosítva. Földrajzi értelemben a pozitív értékeléseket a következő négy területről származtak: Izraelből, Portugáliából, az EU-ból, Ausztráliából és az Egyesült Királyságból. A 18. táblázat az egyes kategóriákba tartozó gondolati egységeket mutatja.

18. táblázat: Az inkubációs fázisban történő állami kockázati tőkés beavatkozás pozitív megnyilvánulásai

\begin{tabular}{|c|c|c|c|}
\hline $\begin{array}{c}\text { Felhasznált releváns } \\
\text { forrás }\end{array}$ & Kategória & $\begin{array}{l}\text { In-vivo } \\
\text { kódok } \\
\text { száma }\end{array}$ & $\begin{array}{l}\text { Földrajzi } \\
\text { terület }\end{array}$ \\
\hline \multirow{5}{*}{$\begin{array}{c}\text { Frenkel et al. (2008); } \\
\text { Avnimelech, Schwartz, } \\
\text { Bar-El (2007); Bilau, } \\
\text { Mason, Botelho, } \\
\text { Sarkar (2017); } \\
\text { Cumming, Johan } \\
\text { (2009); Grilli, Murtinu } \\
\text { (2014); } \\
\text { Wonglimpiyarat (2016) }\end{array}$} & $\begin{array}{l}\text { A magáninkubátorok nem tudják } \\
\text { teljesen helyettesíteni az állami } \\
\text { inkubátorokat }\end{array}$ & 10 & Izrael \\
\hline & $\begin{array}{l}\text { Állami finanszírozás üzleti } \\
\text { angyalok és inkubátorok részére }\end{array}$ & 8 & $\begin{array}{c}\text { Izrael, } \\
\text { Portugália, } \\
\text { EU, } \\
\text { Ausztrália }\end{array}$ \\
\hline & $\begin{array}{l}\text { Az állami technológiai } \\
\text { inkubátorok képesek támogatni a } \\
\text { kockázati tőkeipart }\end{array}$ & 11 & $\begin{array}{c}\text { Izrael, } \\
\text { Egyesült } \\
\text { Királyság }\end{array}$ \\
\hline & $\begin{array}{l}\text { Az állam előmozdítja az } \\
\text { innovációt }\end{array}$ & 5 & Izrael \\
\hline & ÖSSZESEN & 34 & \\
\hline
\end{tabular}

Forrás: saját szerkesztés

Az izraeli technológiai innovációs program modellje követendő példává vált más országok számára is. 1990 és 1993 között az izraeli állam 28 inkubátort hozott létre, reagálva a megnövekedett bevándorlásra, amely az izraeli csúcstechnológiai ipar számára magasan képzett munkaerőt biztosított. Másfél évtizeddel később Frenkel és szerzőtársai (2008) azt vizsgálták, hogy továbbra is szükség van-e az állami beavatkozásra, vagy a magánszektor átveheti a szerepét. A szerzők egyrészt azt hangsúlyozták, hogy a magáninkubátorok nem képesek teljesen helyettesíteni az állami inkubátorokat. Másrészt az állami inkubátorok sokféle tevékenységet szponzorálnak, illetve személyes, intenzív támogatási rendszert biztosítanak nagyon korai fázistól kezdve a magáninkubátorokkal ellentétben, akik a választott iparágaikra összpontosítanak, és nem képesek intenzív támogatási rendszert kínálni. Emellett az állami technológiai inkubátorprogram támogatja az olyan izraeli nemzeti célokat, mint a regionális fejlesztés, vagy az új bevándorlók támogatása. Ezen kívül 
az állam támogatja a magas kockázatú projekteket, amelyek vagy nem vonzóak a magánbefektetők számára, vagy olyan szektorokban müködnek, melyekben a magánbefektetők nem szeretnének működni.

Összesen 8 pozitív értékelés volt az üzleti angyaloknak vagy inkubátoroknak nyújtott állami finanszírozással kapcsolatban. Az állami inkubátorok stabilitást és biztos kereteket biztosítanak a cég hosszú távú tervezéséhez. Frenkel és szerzőtársai (2008) azt is állították, hogy betöltendő rés keletkezett a kereslet és kínálat között, így az államnak kellett különböző szinteken beavatkozni. Portugáliában az állam nagy hangsúlyt fektet az üzleti angyalok támogatására a korai fázisú startupok előmozdítása céljából, amely közös befektetési programok segítségével költhető el. A portugál üzleti angyalok kifejezésre juttatták, hogy ezt a típusú állami beavatkozást részesítik előnyben (Bilau et al., 2017). Avnimelech és munkatársai (2007) arra jutottak, hogy azok a kockázati tőke által támogatott cégek, amelyek előzőleg állami inkubátoroktól kaptak támogatást, jelentősen javították eredményeiket azokhoz képest, amelyekre nem kaptak állami inkubációs támogatást. Cumming és Johan (2009) az ausztrál állam magvető előtti finanszírozását dicsérték azért, mert ez volt a magvető fázisú finanszírozás elsődleges formája az országban.

Az egyik legfőbb előnye az állami technológiai inkubátoroknak az, hogy képesek támogatni a kockázati tőkepiacot. Frenkel és szerzőtársai (2008) pozitív jelként említették, hogy az állami inkubátorok támogatják a jól képzett bevándorlókat az izraeli csúcstechnológiai szektorban, az állami inkubátorok továbbá növelik az exportot és fejlesztik a perifériát. Az állami inkubátorok létjogosultságát alátámasztja, hogy a magánbefektetők nem hajlandóak ennyire kockázatos, korai $\mathrm{K}+\mathrm{F}$ fázisú céget finanszírozni. Ezen felül az állami inkubátorok ösztönözhetik a magánbefektetést azokon a területeken, amelyeken egyébként nem történne vállalkozási tevékenység. Avnimelech és szerzőtársai (2007) azt is kiemelik, hogy az állami technológiai inkubátorok pozitívan hathatnak a kockázati tőkeiparra azáltal, hogy csökkentik a kockázatitőke-szektorban rejlö hátrányokat.

Végül néhány szerző pozitív hatásként említette, hogy az államok előmozdítják az innovációt: Frenkel és szerzőtársai (2008) azt állították, hogy az állami inkubátorok előmozdítják a tudásátadást az akadémiai és ipari szektor között, eközben segítik a startupperek széles körét a csúcstechnológiai iparban annak érdekében, hogy lehetőségük nyíljon dolgozni az ötletükön. Wonglimpiyarat (2016) szerint az izraeli állami programok - mint például a Yozma program - a technológiai 
inkubátorokkal és a támogató egyetemi $\mathrm{K}+\mathrm{F}$ projektekkel együtt nagy szerepet játszottak az ország csúcstechnológiai központtá válásában.

Frenkel és szerzőtásai (2008) számos előnyét kiemelik az izraeli állami inkubátoroknak, míg néhány hátrányt is említenek. Először is tagadhatatlan, hogy néhány területen a magáninkubátorok jobban tudják támogatni a korai szakaszban lévő cégeket, mint az államiak. Másodszor a kockázati tőkealapok olyan projekteket részesítenek előnyben, amelyeket magáninkubátorok támogatnak az állami inkubátorok által támogatottakkal szemben. Mivel ezek a cikkek túlnyomó részt pozitív értékeléseket tartalmaznak az állam magvető előtti fázisú erőfeszítéseivel kapcsolatban, a $2 d$ propozíció - „Nincs olyan beavatkozási forma, amelyhez csak pozitív hatásokat társitanak” - nem talált támogatásra.

19. táblázat: Az inkubációs fázisban történő állami kockázati tőkés beavatkozás negatív megnyilvánulásai

\begin{tabular}{|c|l|c|c|}
\hline $\begin{array}{c}\text { Felhasznált } \\
\text { releváns forrás }\end{array}$ & \multicolumn{1}{|c|}{ Kategória } & $\begin{array}{c}\text { In-vivo } \\
\text { kódok } \\
\text { száma }\end{array}$ & $\begin{array}{c}\text { Földrajzi } \\
\text { terület }\end{array}$ \\
\hline & $\begin{array}{l}\text { A kockázati tőkealapok hajlamosak } \\
\text { nagyobb befektetéseket eszközölni } \\
\text { magáninkubátorok által támogatott } \\
\text { projektek esetében, mint állami } \\
\text { inkubátorok által támogatottak esetében }\end{array}$ & 1 & Izrael \\
\hline $\begin{array}{c}\text { Frenkel et al. } \\
\mathbf{( 2 0 0 8 ) ;}\end{array}$ & $\begin{array}{l}\text { A magáninkubátorok jobb } \\
\text { szolgáltatásokat nyújtanak, mint az } \\
\text { állami inkubátorok }\end{array}$ & 1 & Izrael \\
\hline
\end{tabular}

Forrás: saját szerkesztés

\subsection{4 Összegzése a szakirodalomban tett javaslatokról}

Számos szerző fogalmazott meg javaslatokat is arról, hogyan tudna az állam javítani a kockázati tőkepiacot célzó programjain, ezeket itt mutatjuk be részletesen (9. kérdés). Ezek a javaslatok hangvételüket és építő jellegüket tekintve eltérőek. 42 gondolati egységet lehetett azonosítani a 26-ból 12 cikkben, amelyek ajánlásokat fogalmaznak meg az állami beavatkozás módjáról. Minden vizsgált földrajzi területtel kapcsolatban voltak ajánlások, amelyeket 11 kategóriába soroltunk (lásd: 20. táblázat).

20. táblázat: Ajánlások az állami beavatkozáshoz

\begin{tabular}{|c|c|c|c|}
\hline $\begin{array}{c}\text { Felhasznált } \\
\text { releváns forrás }\end{array}$ & Kategória & $\begin{array}{c}\text { In-vivo } \\
\text { kódok }\end{array}$ & Földrajzi terület \\
\hline
\end{tabular}




\begin{tabular}{|c|c|c|c|}
\hline & & száma & \\
\hline \multirow{12}{*}{$\begin{array}{l}\text { Bilau, Mason, } \\
\text { Botelho, Sarkar } \\
\text { (2017); } \\
\text { Cumming, } \\
\text { Johan (2009); } \\
\text { Avnimelech, } \\
\text { Schwartz, Bar- } \\
\text { El (2007); Grilli, } \\
\text { Murtinu (2014); } \\
\text { Herrera- } \\
\text { Echeverri, Haar, } \\
\text { Estevez-Bretón } \\
\text { (2014); Tucker, } \\
\text { Chakma, Fedak, } \\
\text { Cimini (2011); } \\
\text { Bauer, Burghof } \\
\text { (2007); Cohen, } \\
\text { Gabbay, } \\
\text { Schiffman } \\
\text { (2012); Frenkel } \\
\text { et al. (2008); Gill } \\
\text { (2015); } \\
\text { Wonglimpiyarat } \\
\text { (2011); Zhang } \\
\text { (2014) }\end{array}$} & $\begin{array}{l}\text { Az államoknak ki kellene } \\
\text { egészíteniük a magán kockázati } \\
\text { tőkét, nem versenyezniük azzal }\end{array}$ & 10 & $\begin{array}{l}\text { Izrael, Egyesült } \\
\text { Királyság, Thaiföld }\end{array}$ \\
\hline & $\begin{array}{l}\text { Az állami kockázati tőkealapoknak } \\
\text { nem kellene versenyezniük } \\
\text { egymással }\end{array}$ & 5 & $\begin{array}{c}\text { Ausztrália, Kanada, } \\
\text { Thaiföld, Egyesült } \\
\text { Államok }\end{array}$ \\
\hline & $\begin{array}{l}\text { Az állami kockázati tőkének koraitól } \\
\text { késői fázisig kellene befektetést } \\
\text { biztosítania }\end{array}$ & 5 & $\begin{array}{l}\text { Kanada, Egyesült } \\
\text { Királyság, Thaiföld, } \\
\text { Egyesült Államok, } \\
\text { Izrael }\end{array}$ \\
\hline & $\begin{array}{l}\text { Az államoknak ösztönzőket kell } \\
\text { alkalmazniuk }\end{array}$ & 4 & $\begin{array}{l}\text { Portugália, EU, } \\
\text { Thaiföld, Egyesült } \\
\text { Államok, Kína }\end{array}$ \\
\hline & $\begin{array}{l}\text { Az intézményi minőség javítása } \\
\text { helyettesíteni tudja az állami } \\
\text { kockázati tőkét }\end{array}$ & 4 & feltörekvő piacok \\
\hline & Perifériális kérdések & 3 & $\begin{array}{l}\text { Izrael, Egyesült } \\
\text { Királyság, } \\
\text { Németország }\end{array}$ \\
\hline & $\begin{array}{l}\text { Az államoknak nem szabadna } \\
\text { befolyásolniuk a részvényesi } \\
\text { gyúlést }\end{array}$ & 5 & Kína \\
\hline & $\begin{array}{l}\text { Az állami finanszírozásnak elegendő } \\
\text { nagyságúnak kellene lennie }\end{array}$ & 3 & $\begin{array}{l}\text { Egyesült Királyság, } \\
\text { Thaiföld, Egyesült } \\
\text { Államok }\end{array}$ \\
\hline & Vállalkozók oktatása & 1 & Portugália \\
\hline & $\begin{array}{l}\text { Az államoknak csökkentenie } \\
\text { kellene a kockázati tőkeipar } \\
\text { függőségét a külföldi } \\
\text { finanszírozástól }\end{array}$ & 1 & Izrael \\
\hline & $\begin{array}{l}\text { Szakszervezeti finanszírozású } \\
\text { alapokat (labor-sponsored funds) } \\
\text { nem lenne szabad használni }\end{array}$ & 1 & Kanada \\
\hline & ÖSSZESEN & 42 & \\
\hline
\end{tabular}

Forrás: saját szerkesztés

A szerzők egyik legfontosabb ajánlása az volt, hogy az államoknak ki kell egészíteniük a kockázatitőke magánszereplőit, és semmilyen körülmények között se versenyezzenek velük. Gill (2015) kijelentette, hogy az államnak részt kellene vennie az Egyesült Királyság vállalkozási szaktudásának újjáépítésében, miközben ügyelnie kell arra, hogy ne magánbefektetőként járjon el. Wonglimpiyarat (2011) hangsúlyozta, hogy a thaiföldi államnak kezdetben katalizátori szerepet kellene játszania az ipar fejlődésében, de hosszú távon a magánszektort kell segítenie a gazdaság vezetésében és irányításában. Bauer és Burghof (2007) hozzátették, hogy 
az államnak kizárólag piaci kudarc esetén szabadna közbelépnie. Egyes iparágak jobban függenek az állami támogatástól, ilyenek például a magán biotechnológiai inkubátorok (Frenkel et al., 2008). Az állam részvételét mindössze néhány területre és néhány helyszínre kellene korlátozni, főként a perifériális régiókra (Frenkel et al., 2008). Mivel a magánszektor magasabb szintű üzleti ismeretekkel és vízióval rendelkezik, a magán és állami szektor kooperációja hasznos lehet. Ebből következően a közszférának nem szabadna teljesen kilépnie a korai fázisú szektorból.

Az állami kockázati tőkealapoknak nem szabadna versenyezniük egymással. Számos olyan országot vizsgálva, mint Ausztrália (Cumming és Johan, 2009), Kanada (Tucker et al., 2011) vagy Thaiföld (Wonglimpiyarat, 2011) a szerzők észrevették, hogy az állam több hasonló programot és kezdeményezést kínál, amelyek versengenek egymással. Ennek oka az lehet, hogy az állami hatóságok több különböző célt követnek, és az egyes különálló állami intézmények egymással átfedésben álló programokat hirdetnek. Tucker és szerzőtársai (2011) rámutattak, hogy több állami finanszírozási ügynökségnek egyesülnie kellene, hogy profitálhassanak a méretgazdaságosságból. Wonglimpiyarat (2011), Cumming és Johan (2009), valamint Bauer és Burghof (2007) is megállapította, hogy az egymással versengő célokkal rendelkező hasonló állami programok nem hatékonyak, mert kiszorítják egymást. Az állami kockázati tőkeprogramokat oly módon kell tervezni, hogy kiegészítsék egymást.

Az állami kockázati tőkének a koraitól a késői szakaszig kellene befektetéseket biztosítania. Világszerte van igény hosszú távú állami pénzügyi támogatásra. Tucker (2011) a kanadai biotechnológiai iparra összpontosított, és megállapította, hogy az államnak a koraitól a késői fázisig kell befektetnie a vállalatokba a siker és a nemzetközi befektetőkkel szembeni befolyás növelése érdekében. Gill (2015) az Egyesült Királysággal és Wonglimpiyarat (2011) Thaifölddel kapcsolatban hozzátette, hogy az állam támogatását hosszú távra kell strukturálni. Cohen és szerzőtársai (2012) Izraellel kapcsolatosan kiemelték, hogy az államnak egyszerre egynél több évre kell jóváhagynia a finanszírozást.

Az államoknak ösztönzőket kell alkalmazniuk. Wonglimpiyarat (2011) az USA piacát tanulmányozta, és egészen hasonló ajánlásokat tett a thaiföldi és kínai állam számára. Az adókedvezményeket és a pozitív politikai kezdeményezéseket egy átfogó innovációs finanszírozási program részeként kellene felhasználni Thaiföldön a vállalkozói befektetések ösztönzésére. Bilau és szerzőtársai (2017) szintén erre az 
irányra koncentrálnak, kijelentve, hogy a portugál üzleti angyalok jobban kedvelik, ha az állam fiskális ösztönzőket alkalmaz olyan beruházások serkentésére, mint az újrabefektetési könnyítések és az adókedvezmények. Ehhez hasonlóan Grilli és Murtinu (2014) a pl. adókedvezményeken keresztül megvalósított közvetlen állami támogatások mellett áll.

$\mathrm{Az}$ intézményi minőség helyettesítheti az állami kockázati tökét. HerreraEcheveri és szerzőtársai (2014) egy ettől nagyban eltérő nézőpontot mutatnak be. A szerzők ökonometriai módszereket alkalmaztak egy feltörekvő piacokat tekintő adathalmazon, és megállapították, hogy egy országban a kockázati tőkebefektetési tevékenység az intézményi minőség pozitív, és az állam közvetlen beavatkozásának negatív függvénye. Az államoknak szóló ajánlásuk az, hogy összpontosítsanak intézményeik fejlesztésére, és így adottak lesznek a feltételek egy virágzó magán kockázati töke ökoszisztéma számára, amely csak minimális állami kockázati tőkebefektetést igényel.

A szerzők Izrael, Németország és az Egyesült Királyság perifériális problémáit is említették. A központosított intézkedések nem tudják megoldani a regionális problémákat. Heger és szerzőtársai (2005) szerint az intézmények regionális bevonása képes lehet kezelni a szükséges pénzügyi programok regionális allokációját. Avnimelech és szerzőtársai (2007) arra is rámutattak, hogy az állami technológiai inkubátorok sikeresen vonzották a beruházásokat Izrael periférikus területeire, még akkor is, ha szerény sikerarányokkal rendelkeznek.

Zhang (2014) a kínai állami kockázati tőke müködtetése kapcsán a kínai állami vállalatok vállalatirányítására összpontosított, összehasonlítva ezt az amerikai kockázati tőkével. Kínában az állam a befektetés után szintén tulajdonossá válik, így ellenőrizni tudja a vállalat működését. A szerző arra a következtetésre jutott, hogy az államnak nem szabad befolyásolnia a részvényesi közgyülést.

Az állam finanszírozásának elegendő nagyságúnak kell lennie. Az egyesült királyságbeli Gill (2015) és a thaiföldi Wonglimpiyarat (2011) hangsúlyozta, hogy elegendő erőforrás elosztása elősegítheti a startupok versenyképessé válását. Wonglimpiyarat (2011) arra buzdítja a thaiföldi államot, hogy támogassa a startupok minden fajtáját.

Portugáliai felmérésük alapján Bilau és szerzőtársai (2017) azt javasolták, hogy az állam összpontosítson a beruházások hatékonyságának javítására. Hozzáteszik, hogy az államnak a vállalkozók oktatására kell összpontosítania, nem olyan 
workshopok és fórumok megszervezésére, ahol a finanszírozók és a fiatal cégek találkozhatnak. Cohen és munkatársai (2012) problémásnak találták az izraeli csúcstechnológiai ipar külföldi befektetőktől (elsősorban az Egyesült Államoktól) való függését. Szerintük az államnak meg kellene próbálnia eltávolítani az akadályokat az izraeli intézményi befektetők és a csúcstechnológiai szektor között. Tucker és szerzőtársai (2011) hangsúlyozták, hogy az alapoknak nem szabadna támogatniuk a munkaerőköltségeket.

\section{6 Összefoglalás}

E fejezetben áttekintést adtunk az állami kockázati tőke kutatási területéről 2000 és 2018 között a Scimago által minősített folyóiratok cikkeinek áttekintésével. A kérdés releváns, mivel a startup cégek elősegíthetik a gazdasági növekedést. Bizonyos piaci kudarcok miatt a startupperek számára nehéz kezdeti finanszírozást szerezni. Világszerte az államok különféle programokkal törekednek oldani ezeket a kockázati tőkepiaci kudarcokat. Számos állami kockázati tőkeprogramot hirdettek meg a fiatal cégek támogatására, és a kutatók szívesen vizsgálták az állami beavatkozás okát és hatékonyságát. Így két fő kutatási irány került azonosításra: azon cikkek csoportja, amelyek az állami kockázati tőkepiaci beavatkozás okát vizsgálják, és azon cikkeké, amelyek az állami kockázati tőkepiaci beavatkozás hatásait elemzik. A következő táblázat a propozíciókkal kapcsolatos eredményeket tartalmazza.

21. táblázat: A 4. fejezet eredményeinek táblázata

\begin{tabular}{|c|c|c|c|c|}
\hline & Propozíció & $\begin{array}{c}\text { Támogatásra } \\
\text { talált }\end{array}$ & $\begin{array}{l}\text { Részben } \\
\text { támogatás- } \\
\text { ra talált }\end{array}$ & $\begin{array}{l}\text { Nem talált } \\
\text { támogatás- } \\
\text { ra }\end{array}$ \\
\hline 1 a p. & $\begin{array}{l}\text { A kutatási terület cikkei a legmagasabb } \\
\text { minőségü Scimago által minősített } \\
\text { folyóiratokban jelentek meg (1-2. } \\
\text { kérdés). }\end{array}$ & $x$ & & \\
\hline $1 b \mathrm{p}$. & $\begin{array}{l}\text { A kutatási terület cikkei elsősorban } \\
\text { ökonometriai elemzést alkalmaznak } \\
\text { kutatási módszertanként. }\end{array}$ & $x$ & & \\
\hline $1 \mathrm{c} \mathrm{p.}$ & $\begin{array}{l}\text { A kutatási terület iránti érdeklődés } \\
2000 \text { és } 2018 \text { között elsősorban a } \\
\text { különböző gazdasági válságokra adott } \\
\text { állami válaszoknak köszönhető. }\end{array}$ & $X$ & & \\
\hline $1 d \mathrm{p}$. & $\begin{array}{l}\text { A cikkek elsősorban az amerikai } \\
\text { állami kockázati tőke } \\
\text { kezdeményezéseket vizsgálják. }\end{array}$ & & & $x$ \\
\hline 2 a p. & $\begin{array}{l}\text { A cikkek elsősorban a kockázati } \\
\text { tőkepiac állami beavatkozásának } \\
\text { közvetlen és a privát szektorral }\end{array}$ & & $x$ & \\
\hline
\end{tabular}


partnerségben végrehajtott formáját

vizsgálják.

2b p. A cikkek elsősorban negatív hatásokat társítanak a közvetlen állami

beavatkozáshoz.

2c p. A cikkek pozitív és negatív hatásokat

egyformán társítanak az állami-privát

partnerségú kockázati tőkéhez.

2d p. Nincs olyan beavatkozási forma,

amelyhez csak pozitív hatásokat

társítanak.

Forrás: saját szerkesztés

2000 és 2018 között 26 cikket publikáltak a témában, kizárólag Q1 és Q2 minősítésü folyóiratokban. Ezeket a cikkeket számos dimenzió szerint kategorizáltuk. A cikkek vizsgált földrajzi területei az Egyesült Államokat, Kanadát, Európa számos országát, Izraelt, Kínát, Thaiföldet, Dél-Koreát és Ausztráliát fedik le. A cikkek vizsgált időszakai főként a 90-es évek elejétől 2014-ig terjednek. Gill (2015) 1945-től vizsgálta az Egyesült Királyság kockázati tőkepiaci állami beavatkozását, ami ebben az értelemben kiugró érték.

A fejezetben kvalitatív tartalomelemzés segítségével mutattuk be részletesen az állam korai fázisú vállalatok finanszírozása kapcsán tett beavatkozásait. Bemutattuk a beavatkozás különböző formáit értékelő cikkek által felsorolt pozitív és negatív példákat. A nyers in vivo kódokat témákba, majd kategóriák rendeztük. Az azonosított témák a részvétel formáinak felelnek meg: ezek a tisztán állami kockázati tőke, az állami és magán kockázati tőke partnersége, az államilag támogatott magvető előtti fázisú finanszírozás, illetve az ajánlások voltak. A bemutatott megfigyelések eltérőek voltak a földrajzi elhelyezkedés, az alkalmazott kutatási módszer és a beavatkozás formája függvényében. A tisztán állami kockázati tőkével kapcsolatban megállapításra került, hogy nem szorítja ki a magán kockázati tőkét az európai adatok felhasználásával végzett vizsgálatok esetében, de a szerzők ennek az ellenkezőjét tapasztalták a feltörekvő piacok vizsgálatakor. Számos földrajzi helyszínen találták a tisztán állami kockázati tőkebefektetéseket kevésbé hatékonynak, mint a magán kockázati tőkebefektetéseket. Ezen kívül az állami és magán kockázati tőkés partneri kapcsolatokat a legtöbb cikk azért dicséri, mert azok jobb befektetéseket hajtanak végre a tisztán állami és a tisztán magán kockázati tőkénél. A közép-kelet-európai állami és magán partneri kockázati tőkeprogramok 
kapcsán ugyanakkor azt kritizálták, hogy túl rövidek, kis léptéküek és bürokratikusak. Megállapítást nyert, hogy az inkubációs fázisú, technológiai inkubátorokon keresztül történő állami támogatás segíti a kockázati tőke ágazatot és elősegíti Izrael nemzeti célkitüzéseit. Annak ellenére, hogy a technológiai magán inkubátorokról kiderült, hogy jobb szolgáltatásokat nyújtanak, mint az állami inkubátorok, nem helyettesíthetik azokat, mivel az állami inkubátorok sokkal több induló vállalkozást támogatnak, mint a magán inkubátorok. Portugália esetében az állam üzleti angyal finanszírozást támogató sikeres intézkedései figyelhetők meg.

22. táblázat: Az azonosított pozitív és negatív megnyilvánulások összehasonlítása

\begin{tabular}{|l|c|c|}
\hline Téma & $\begin{array}{c}\text { Pozitív } \\
\text { megnyilvánulások } \\
\text { száma az in vivo } \\
\text { kódokban }\end{array}$ & $\begin{array}{c}\text { Negatív } \\
\text { megnyilvánulások } \\
\text { száma az in vivo } \\
\text { kódokban }\end{array}$ \\
\hline $\begin{array}{l}\text { Állami és magán kockázati tőke } \\
\text { partnersége }\end{array}$ & 17 & 12 \\
\hline Állami részvétel az inkubációs fázisban & 34 & 2 \\
\hline Tisztán állami részvétel & 24 & 24 \\
\hline Összefoglalás & $\mathbf{7 5}$ & $\mathbf{3 8}$ \\
\hline
\end{tabular}

Forrás: saját szerkesztés

A cikkekben tett javaslatok 11 kategóriába kerültek besorolásra. A leggyakoribb ajánlás az volt, hogy az államoknak ki kellene egészíteniük a magánszektort, nem versenyezniük azzal. Ez a javaslat jelentős következménnyel jár a további kutatások szempontjából, hiszen az állam nem tudott tisztességes hozamot realizálni a befektetési alapjain, így alapvetően helytelen a teljesítményét a magánszektoréhoz hasonlítani. Ezen kívül, amikor a realizált hozam alacsonyabb, mint a magánbefektetőké, az állam ügynökeit hibáztatják az állam által biztosított források gondatlan kezeléséért. De még ha jobban teljesítenek is, mint a magánbefektetők, akkor is hibáztathatóak a magánbefektetők kiszorításáért. Így az államoknak biztosítaniuk kell a startupok számára a lehetőséget a kutatás-fejlesztésre, majd a lehető legkorábban át kell adniuk a magánbefektetőknek a társaság finanszírozását. Ebből következően az állam hatékonyságát azon projektek száma alapján kellene mérni, amelyeket kivásárolt a magánszektor. Egy másik fontos globális javaslat, hogy az állam által hirdetett programoknak ki kellene egészíteniük egymást. 
Összefoglalásképpen elmondható, hogy az államoknak a nagyon kockázatos magvető előtti fázisban kellene beavatkozniuk a projektek finanszírozásával és a vállalkozók oktatásával. Ezen kívül az államoknak stabil intézményi hátteret kell biztosítaniuk, amely szintén csökkentheti az állami beavatkozás szükségességét. 


\section{A magyar kockázati tőkepiac és az állam³}

Az előző fejezetben egyrészt azokat a piaci kudarcokat mutattuk be a kockázati tőkepiacon, amelyek igazolják az állami beavatkozást. Másrészt átfogó kvalitatív szisztematikus szakirodalmi összefoglaló alapján ismertettük az állami kockázati tőkével kapcsolatos nemzetközi kutatások legfontosabb eredményeit és megmutattuk a „legjobb gyakorlatát” az állami programoknak. A jelen kutatásban a hazai kockázati tőkepiacra és a magyar állami kockázati tőkés programokra helyezzük a vizsgálat fókuszát. A fejezetben bemutatjuk a hazai kockázati tőkepiac fejlődését, számos megvalósult vagy folyamatban lévő állami kockázati tőkeprogramot, valamint a legfontosabb állami tulajdonú kockázati tőkealap-kezelőket a kezelt alapokkal együtt. Végül értékeljük a nemzetközi állami kockázat tőkés programok tanulságai alapján a hazai gyakorlatot.

\subsection{Kutatási kérdések}

A kutatásunkban a közvetett és közvetlen állami intervenciót vizsgáljuk a magyar kockázati tőkepiacon, ezért a kutatási kérdéseket ennek megfelelően két csoportra osztjuk.

\section{3. táblázat: Kutatási kérdések az 5. fejezethez}

1. Milyen fázisokon ment keresztül a magyar kockázati tőkepiac fejlődése során?

2. Milyen tulajdonságai voltak a Jeremie programnak a biztosított tőkét, a nyertes alapkezelők számát és az időtartamát tekintve?

3. Hogyan értékelhetjük a Jeremie program eredményeit?

4. Hogyan tükrözte a Jeremie program kivitelezése az állami kockázati tőkés programok legjobb nemzetközi gyakorlatait?

5. Milyen formában avatkozik be a magyar állam közvetlenül a kockázati tőkepiacon?

6. Melyek a közvetlen beavatkozás stratégiai céljai?

7: Hogyan változtatta meg a COVID-19 járvány a közvetlen állami beavatkozást?

\section{Forrás: saját szerkesztés}

Az 1. kutatási kérdés célja, hogy feltérképezze a magyar kockázati tőkepiacot, ezzel megalapozva a későbbi vizsgálatokat. A következő három kutatási kérdés (2.3.-4. kérdés) a magyarországi közvetlen állami kockázati tőkepiaci intervenciót térképezi fel. Először bemutatjuk a Jeremie program tulajdonságait a források

${ }^{3}$ Ez a fejezet tartalmazza a Jáki Erikával és Walter Györggyel végzett kutatásom néhány eredményét, amelyből készült tanulmányok a Management, Slovenia folyóiratban (Jáki et al., 2017) és az ECMS konferenciakiadványában (Jáki \& Molnár, 2017) jelentek meg. 
mérete, a győztesek száma, illetve az időtartam tekintetében (2. kérdés), majd megmutatjuk, hogyan értékelték a kutatók a programot (3. kérdés). A 4. kutatási kérdés esetében összevetjük a hazai gyakorlatot a nemzetközi szakirodalmi áttekintés alapján meghatározott legjobb gyakorlatokkal. Az utolsó három kutatási kérdésnél (5-6-7. kérdés) a közvetlen hazai állami intervencióval foglalkozunk oly módon, hogy megvizsgáljuk az állami tulajdonú kockázati tőkealap-kezelöket és a kezelt alapjaikat (5. kérdés), ezen alapok stratégiai céljait (6. kérdés), és az állam közvetlen beavatkozással történő válaszát a COVID-19 járványra (7. kérdés).

24. táblázat: Propozíciók az 5. fejezethez

1a propozíció: Az állam eredetileg azért lépett be a kockázati tőkepiacra, hogy kitöltse a finanszírozási rést a korai fázisú finanszírozási szegmensben, ahol a magán kockázati tőkebefektetők inaktívak voltak.

1b propozíció: A Jeremie program lefolyása során növelte a kockázati tőkebefektetési tevékenységet Magyarországon.

1c propozíció: A Jeremie program sikeresen elérte regionális fejlesztéssel kapcsolatos célját.

1d propozíció: A Jeremie program sikeresen finanszírozta a befektetést legjobban igénylő korai fázisú cégeket.

1e propozíció: A Jeremie program pozitív hatással volt a céltársaságokra.

1f propozíció: A Jeremie program győztes alapkezelőinek kiválasztása átlátható folyamat volt.

1 1g propozíció: A Jeremie program kivitelezése követte a legjobb nemzetközi gyakorlatokat.

2a propozíció: A hazai állam a Jeremie program lefolyása során közvetlen módon is beavatkozott a kockázati tőkepiacon.

2b propozíció: A hazai állam fókuszát a közvetett beavatkozásról a közvetlen beavatkozásra helyezte át a Jeremie programot követően.

2c propozíció: A hazai közvetlen állami beavatkozás stratégiai céljai közé tartozik a pozitív externáliát termelő cégek finanszírozása.

2d propozíció: Az állam közvetlen kockázati tőkés beavatkozást alkalmazott a COVID-19 járványra adott válasza során.

Forrás: saját szerkesztés

\subsection{Módszertan}

A kutatásunk első részét, a hazai állami beavatkozás kutatását három részre lehet osztani:

- Először a hazai kockázati tőkepiac fejlődését mutatjuk be szekunder adatforrásokra támaszkodva a fejlödést leíró tanulmányok és az Invest Europe éves jelentéseit használva. 
- A második rész a közvetett állami beavatkozást, kiemelten a Jeremie program menetét mutatja be, mint legfontosabb magyarországi közvetett állami kockázati tőkés beavatkozás. Értékelésére nyilvánosan elérhető adatok, mint például a hivatalos közlemények, tudományos publikációk és a kutatóintézetek elemzései szolgáltak. A program kivitelezése az nemzetközi megállapítások mentén a nemzetközi legjobb gyakorlatokkal kerül összevetésre.

- A harmadik rész a magyar állam közvetlen kockázati tőkés állami beavatkozási kezdeményezéseit mutatja be a magyar állami alapkezelő társaságok honlapjairól nyilvánosan elérhető adatok alapján. Itt bemutatott adatok például a kezelt alapok nagysága, a kezelt alapok befektetési politikája, és ha rendelkezésre állt, a végrehajtott befektetések nagysága is.

\subsection{A hazai kockázati tőkepiac fejlődése}

A magyar kockázati tőkepiac legkorábbi szakaszától történő bemutatásakor problémába ütközünk (1. kérdés). Ennek oka, hogy a korai időszakból, a 90-es évekből kevés adatforrás és tanulmány áll rendelkezésre. A fő adatforrás ezen a piacon az 1991-ben alapított Magyar Kockázati- és Magántőke Egyesület (HVCA), amelynek valamennyi magyar magántőkés és kockázati tőkealap-kezelőnek tagjának kell lennie, és részt kell vennie az adatszolgáltatásban.

A HVCA publikálta a legkorábbi hazai kockázati tőkéről és magántőke-piacról szóló kérdőív alapú leírást 2005-ben (Karsai és Baranyai, 2005), amely a piac 19892005 közötti fejlődését mutatta be. A kérdőív a magyar alapkezelőkről (befektetéshez rendelkezésre álló tőke, összbefektetés, exitek), és a vizsgált időtartam alatt létrejött tranzakcióikról gyüjtött adatokat. A befektetőkről gyüjtött adatokat sajtóban hozzáférhető adatokkal egészítették ki. A szerzők megállapították, hogy az első 15 év alatt a piac a növekedési fázisú befektetésekre fókuszált (a tranzakciók 64\%-a és a befektetési volumen $80 \%$-a ebben a szegmensben jött létre), míg a korai fázisú befektetések a piac kis részét tették ki (a tranzakciók 32\%-a és a befektetési volumen 10\%-a). A szerzők négy fázisra osztják a piac fejlődését. Az első két fázis csak magántőkés befektetési aktivitást tartalmazott, és a hagyományos kockázati tőkebefektetések csak a harmadik fázisban jelentek meg. A következő, 2005-2010 
közötti időszakot a HVCA további felmérése mutatta be, amelyből megismerhetjük a piac további fejlődését (Karsai, 2011A; Karsai, 2011B).

- Az első szakaszra (1989-1992) két típusú alap volt jellemző: a globális alapok, amelyek külföldi állami forrásokat fektettek be, és az úgynevezett „országalapok”, amelyek tipikusan egy országban fektettek be. Ezen alapok átlagos mérete kb. 50 millió dollár volt, ami kicsinek számít a nemzetközi befektetési alapok esetében, mivel a magyar piacon még nem rendelkeztek elég magabiztossággal. A privatizáció központi szerepet játszott ezekben a befektetésekben.

- A második szakaszban (1993-1997) Közép-Kelet-Európára összpontosító regionális alapok léptek piacra, valamint néhány szektorális alap is, amelyek egy-egy iparágra fókuszáltak. Ezeknek az alapoknak a mérete 100 és 200 millió dollár közé esett. Ebben a szakaszban terelődött a fókusz a hazai cégek terjeszkedésének finanszírozására.

- A harmadik szakaszban (1998-2000) a regionális alapok domináltak, és a beruházások fókuszában elsősorban a technológiai vállalatok finanszírozása állt. Az alapok mérete ismét nőtt, immár 250-300 millió dollárra. Ebben a fázisban született meg a kockázati tőkebefektetési ágazat a magántőkés szektoron belül. A kockázati tőkepiac szereplöi technológiai, információs technológiai, illetve médiacégekbe kezdtek befektetni.

- A negyedik szakaszban (2001-2005) a piac áramvonalasodása következett be, vagyis csak a legsikeresebb alapkezelő társaságok maradhattak a piacon. Megjelentek a specializált befektetők és a kivásárlási finanszírozás. Az állami befektetők jelenléte növelte a kkv-k finanszírozását. Az ország Európai Unióba történő belépésével az új globális befektetők nagy értékü kivásárlásokban és strukturált tranzakciókban kezdték meg tevékenységüket.

- Az ötödik szakasz (2005-2010) nagy részét nagy nemzetközi érdeklődés jellemezte a fejlődő magyar piac iránt, nőtt a piacon müködő globális alapok száma (2008-ban tetőzött). Ezt az előnyös időszakot rövidre zárta a 2008-as pénzügyi válság, és a magántőke és kockázati tőkealapok befektetett tőkéje zuhanásnak indult. Ennek köszönhetően 2009-2010-ben a globális alapok kivonulásával az országos alapok váltak a piac legnagyobb befektetőivé. 
A hagyományos kockázati tőkés szegmensnek a válság okozta visszaesése egyértelmüen látható a 15. ábrán, amely az Invest Europe adatainak felhasználásával ezer euróban mutatja a kockázati tőkebefektetés volumenét Magyarországon 2007 és 2018 között az életciklus különböző szakaszaiban.

15. ábra: A magyarországi kockázati tőkebefektetési volumen 2007 és 2018 között az életciklus különböző szakaszaiban, ezer euróban

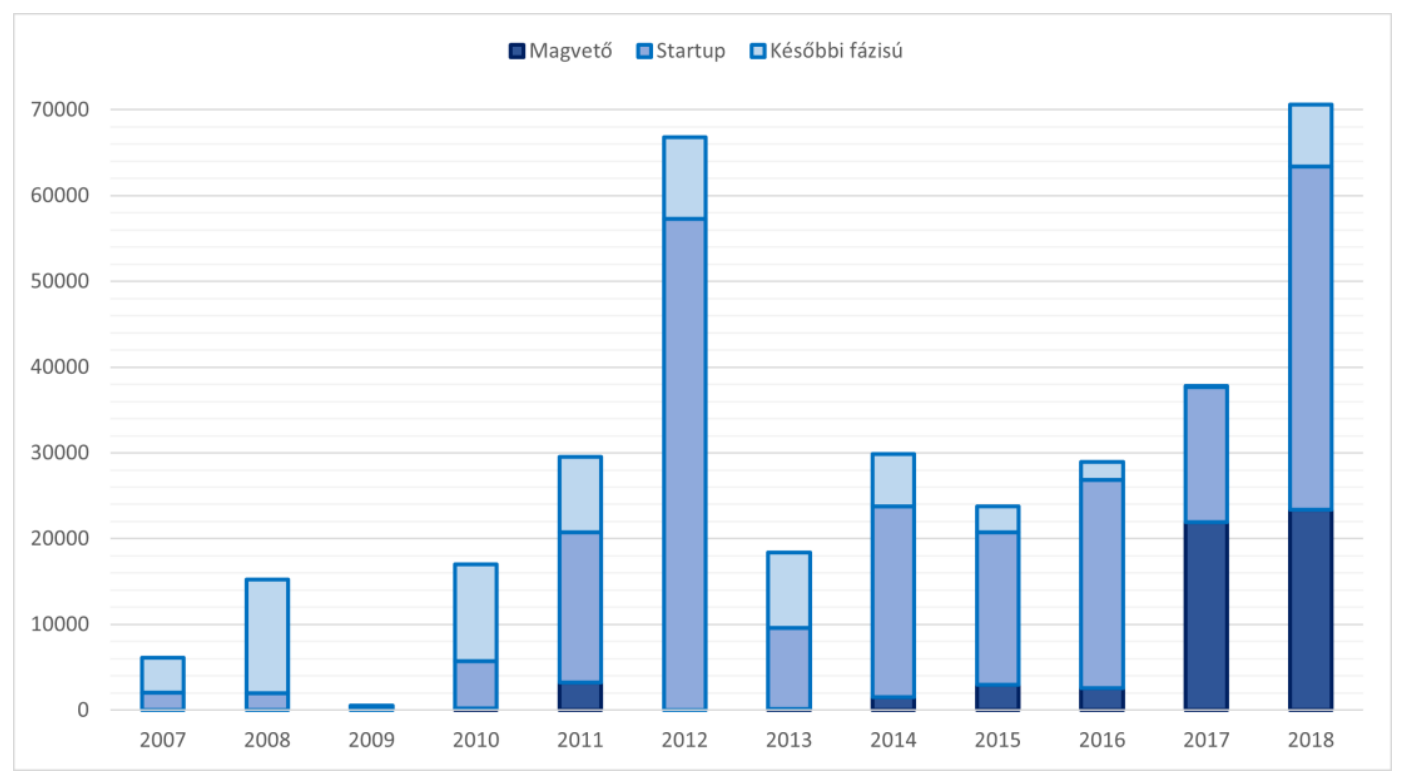

(Forrás: Invest Europe, 2017; Invest Europe, 2019)

- 2007-től 2016-ig felerősödött az állami kockázati tőkés aktivitás a piacon közvetett beavatkozás (Jeremie program) és közvetlen intervenció (Széchenyi Tőkealap-kezelö) formájában; a két kezdeményezés az országban végrehajtott összes kockázati tőkebefektetés háromnegyedét adta a 2007-2016 közötti időszakban (Karsai, 2017b). 2017 óta az SZTA befektetéseinek volumene csökkent, és a Hiventuresé lett a vezető szerep állami kockázati tőkefinanszírozás elosztásában (SZTA; 2020, Invest Europe; 2017, Invest Europe; 2020).

A privát kockázati tőkések a későbbi fázisú befektetéseket részesítik előnyben a koraikkal szemben, mert számára nem gazdaságos bizonyos befektetési volumen alatt befektetni, és nem tolerálják az ezen befektetésekhez kapcsolódó magas kockázatot sem. Ez a befektetési magatartás nemcsak a 2000-es évtized végén figyelhető meg, ahogy a 15. ábra mutatja, hanem a korábbi időszakokban is. Karsai (2011B) arra világít rá, hogy 1989 és 2010 között a kockázati tőkebefektetések 
volumenének csak 4\% -át tették ki korai stádiumú cégek. A magyar állam korai stádiumú vállalatokba történő közvetlen befektetéssel már 2002-ben belépett a kockázati tőkepiacra, 1989 és 2010 között a teljes kockázati tőkebefektetés 17,5\% -át biztosítva, így az la propozíció - „Az állam eredetileg azért lépett be a kockázati tökepiacra, hogy kitöltse a finanszírozási rést a korai fázisú finanszírozási szegmensben, ahol a magán kockázati tökebefektetők inaktívak voltak” támogatásra talált. Azonban a 2008-as válság pusztító hatásai miatt nagyobb állami beavatkozásra volt szükség a piac újraélesztéséhez. Uniós kockázati tőkeprogram keretében végrehajtott állami beavatkozásnak köszönhetően a kockázati tőkepiac gyorsan helyreállt, és már 2010-re meghaladta a 2008-as beruházási volument (lásd: 15. ábra).

\subsection{Közvetett állami beavatkozás - a JEREMIE program}

A 2007-2013-as tervezési időszakban a közvetett állami beavatkozás vált jellemzővé a magyar piacon. Az Európai Unió az úgynevezett „Jeremie program” keretein belül biztosított forrásokat, melyet az állam közvetítésével bocsát a magánszektor alapkezelői részére.

\subsubsection{A Jeremie program története és folytatása Magyarországon}

2009-ben az állam elindította a Jeremie I. programot Magyarországon. A forrásokat pályázati rendszeren keresztül több szakaszban osztották szét az alapok között. A Jeremie (Joint European Resources for Micro to medium Enterprises „Közös európai források a mikro- és középvállalkozásoknak”) programot az Európai Bizottság alapította az Európai Beruházási Alappal együtt. A program mikro-, kis- és középvállalkozásokat támogatott. Ez a tőkeinjekció új lendületet adott a magyar kockázati tőkebefektetéseknek. A Jeremie programot vizsgálhatjuk az alapok nagysága, a nyertes alapkezelő társaságok és az időtartam tekintetében (2. kérdés).

Az Új Magyarország Kockázati Tőkeprogram (ami Jeremie I. néven is ismert) 8 nyertes kockázati tőkealap és tőkealapkezelöjük között osztott szét forrásokat. Mivel ezek az alapkezelők a magánszektor tulajdonában voltak, ez a fajta állami intervenció közvetett, hiszen az állam által nyújtott forrásokat a magán tőkealapkezelők kezelik. Az alapok teljes volumene kb. 48 milliárd forint volt, amelyen belül legalább 30\% magánszektortól származó befektetés, és maximum 
$70 \%$ állami forrás volt jellemző minden alap esetében. A legkisebb alap 4 milliárd, és legnagyobb 7,36 milliárd forint volt (MV Zrt, 2013).

A magyar állam 27 milliárd forintos tőkét nyújtott a helyi kockázati tőkebefektetőknek 2012-ben. A fő források az Európai Regionális Fejlesztési Alaptól érkeztek az Új Széchenyi Kockázati Tőkeprogram - Gazdaságfejlesztési Operatív Program 4. keretében. Ezt Jeremie II. programnak is hívták. A programban 6 milliárd forintot lehet befektetni az úgynevezett Közös Magvető Alap alprogramon keresztül a 3 évnél nem régebbi alapítású, maximum 200 millió forintos árbevétellel rendelkező mikro- vagy kkv-k finanszírozására. Az alapok a fennmaradó 22,5 milliárd forintot a Közös Növekedési Alap alprogramon keresztül mikrovállalkozások, kkv-k és 5 évnél nem régebben alapított, maximum 5 milliárd forintos árbevétellel rendelkező középvállalkozások számára fektethették be (Palyazat.gov.hu, 2012). Az összes alap teljes nagysága 41 milliárd forint volt, a legkisebb alap nagysága 2,14 milliárd forint volt, a legnagyobb alap 6,5 milliárd forintot kapott (MV Zrt. 2013).

A nyolc alapból hét közös alap volt, tehát a magánbefektetőnek a saját forrásait (30\%) az induláskor kellett rendelkezésre bocsátania, míg egy alap co-investment alap volt. A co-investment alapok esetében induláskor az állam biztosította az összes forrást, de privát partnerbefektetőt kellett keresnie minden alkalommal, amikor az alap befektetést kívánt eszközölni. Eszerint a befektetési politika rugalmasabb lehetett, mivel az alap a különböző típusú befektetésekhez legjobban illő magánbefektetőket kereshetett (Századvég, 2016).

25. táblázat: A JEREMIE I-II. nyertesei

\begin{tabular}{|l|l|c|}
\hline \multicolumn{2}{|c|}{ Új Magyarország Kockázati Tőkeprogram } \\
\hline \multicolumn{1}{|c|}{ Alapkezelő } & \multicolumn{1}{|c|}{ Kezelt alap } & $\begin{array}{c}\text { Alap mérete (millió } \\
\text { Ft) }\end{array}$ \\
\hline $\begin{array}{l}\text { Biggeorge's-NV EQUITY } \\
\text { Kockázati Tőkealap-kezelő } \\
\text { Zrt. }\end{array}$ & $\begin{array}{l}\text { Biggeorge's-NV EQUITY I. } \\
\text { Kockázati Tőkealap }\end{array}$ & 4000 \\
\hline $\begin{array}{l}\text { Central-Fund Kockázati } \\
\text { Tőkealap-kezelő Zrt. }\end{array}$ & $\begin{array}{l}\text { CenTech Új Magyarország } \\
\text { Kockázati Tőkealap }\end{array}$ & 5000 \\
\hline DBH Investment Zrt. & $\begin{array}{l}\text { DBH Investment Kockázati } \\
\text { Tőkealap }\end{array}$ & 5000 \\
\hline $\begin{array}{l}\text { Euroventures Kockázati } \\
\text { Tőkealap-kezelő Zrt. }\end{array}$ & $\begin{array}{l}\text { Euroventures IV Kockázati } \\
\text { Tőkealap (Co-investment } \\
\text { Fund) }\end{array}$ & 7097 \\
\hline
\end{tabular}




\begin{tabular}{|c|c|c|}
\hline \multicolumn{3}{|c|}{ Új Magyarország Kockázati Tőkeprogram } \\
\hline Alapkezelő & Kezelt alap & $\begin{array}{l}\text { Alap mérete (millió } \\
\text { Ft) }\end{array}$ \\
\hline $\begin{array}{l}\text { Finext Startup Kockázati } \\
\text { Tőkealap-kezelő Zrt. }\end{array}$ & $\begin{array}{l}\text { Finext Startup Kockázati } \\
\text { Tőkealap }\end{array}$ & 7360 \\
\hline $\begin{array}{l}\text { MORANDO Kockázati } \\
\text { Tökealap-kezelő Zrt. }\end{array}$ & Morando Kockázati Tőkealap & 6506 \\
\hline $\begin{array}{l}\text { Portfolion Kockázati } \\
\text { Tőkealap-kezelő Zrt. }\end{array}$ & OTP Kockázati Tőkealap I. & 6800 \\
\hline $\begin{array}{l}\text { Primus Capital Kockázati } \\
\text { Tőkealap-kezelő Zrt. }\end{array}$ & Primus III. Kockázati Tőkealap & 6200 \\
\hline \multicolumn{3}{|c|}{$\begin{array}{c}\text { Új Széchenyi Kockázati Tökeprogram } \\
\text { (Közös Magvetö Alap - Közös Növekedési Alap) }\end{array}$} \\
\hline Alapkezelő & Kezelt alap & $\begin{array}{l}\text { Alap mérete (millió } \\
\text { Ft) }\end{array}$ \\
\hline $\begin{array}{l}\text { Bonitás Kockázati Tökealap- } \\
\text { kezelö Zrt. }\end{array}$ & Bonitás Kockázati Tőkealap & 6500 \\
\hline $\begin{array}{l}\text { Első Magyar Kockázati } \\
\text { Tőkealap-kezelő Zrt. }\end{array}$ & $\begin{array}{l}\text { Conor Seed Capital Kockázati } \\
\text { Tökealap }\end{array}$ & 2150 \\
\hline $\begin{array}{l}\text { Core Venture Kockázati } \\
\text { Tőkealap-kezelő Zrt. }\end{array}$ & $\begin{array}{l}\text { Core Venture Közös Magvetö } \\
\text { Kockázati Tökealap }\end{array}$ & 2145 \\
\hline \multirow[t]{2}{*}{$\begin{array}{l}\text { Kairos Kockázati Tőkealap- } \\
\text { kezelő Zrt. }\end{array}$} & $\begin{array}{l}\text { Kairos Magvetö Kockázati } \\
\text { Tökealap }\end{array}$ & 2143 \\
\hline & $\begin{array}{l}\text { Kairos Novekedési Kockázati } \\
\text { Tőkealap }\end{array}$ & 6429 \\
\hline $\begin{array}{l}\text { New York Kockázati } \\
\text { Tőkealap-kezelö Zrt. }\end{array}$ & New York Kockázati Tőkealap & 4300 \\
\hline \multirow[t]{2}{*}{$\begin{array}{l}\text { Prosperitás Kockázati } \\
\text { Tőkealap-kezelö Zrt. }\end{array}$} & $\begin{array}{l}\frac{\text { Prosperitás Profit Közös }}{\text { Növekedési Kockázati }} \\
\underline{\text { Tökealap }}\end{array}$ & 6430 \\
\hline & $\begin{array}{l}\text { Prosperitás Proseed Közös } \\
\text { Magvetö Kockázati Tökealap }\end{array}$ & 2150 \\
\hline $\begin{array}{l}\text { Venturio Kockázati Tőkealap- } \\
\text { kezelő Zrt. }\end{array}$ & $\frac{\text { Venturio 2013. Kockázati }}{\text { Tökealap }}$ & 4412 \\
\hline $\begin{array}{l}\text { X-Tech Capital Kockázati } \\
\text { Tőkealap-kezelő Zrt. }\end{array}$ & X-Tech I. Kockázati Tökealap & 4288 \\
\hline
\end{tabular}

Forrás: (MV Zrt., 2013)

A fenti táblázat megmutatja a győztes alapkezelőket, az általuk kezelt alapokat, illetve az Új Magyarország Kockázati Tőkeprogram (Jeremie I. néven is ismert) és az Új Széchenyi Kockázati Tőkeprogram (Jeremie II. néven is ismert) alapjainak méretét. Az alapok méretébe beletartoznak mind az állam, mind a magánbefektetők által biztosított források.

A Széchenyi Tőkeprogram Közös Növekedési Alap alprogramja több lépésben bővült. A Jeremie III.-nak nevezett fázisban nyolc kockázati tőkealap-kezelő kapott 
egyenként 3 milliárd forintot 2013-ban (Innovációs és Technológiai Minisztérium, 2013). A nyertesek az alábbiak voltak:

1. Alliance Jura-Hongrie Kockázati Tökealap-kezelő Zrt.

2. Perion Invest Kockázati Tőkealap-kezelő Zrt.

3. Tőkepartner Kockázati Tőkealap-kezelő Zrt.

4. Dinamo Ventures Kockázati Tőkealap-kezelö Zrt.

5. Hemisphere Kockázati Tőkealap-kezelö Zrt.

6. PBG FMC Kockázati Tőkealap-kezelő Zrt.

7. Valor Capital Kockázati Tőkealap-kezelő Zrt.

8. Core Venture Kockázati Tőkealap-kezelő Zrt.

A Jeremie IV.-nek nevezett fázisban (GOP-2013-4.3/B/2) 2013-ban csak két alapkezelő nyert el egyenként 3 milliárd forintot: a Gran Private Equity Zrt. és a Garangold Investment Befektető Zrt. Végül az utolsó szakaszban (GOP-2014-4.3/B, amelyet időnként Jeremie V.-nek is hívtak) 2014-ben 2,7 milliárd forinttal díjazták a Valor Capital Kockázati Tőkealap-kezelő Zrt-t (Equinox Consulting, 2016).

A Jeremie programon kívül más közvetett állami beavatkozási formák is megjelentek a magyar kockázati tőkepiacon. Az Export-Import Bank Zrt. két alapot indított állami forrásból 2015-ben, és az alapok - összesen 16 milliárd forint kezelésének jogát a GB \& Partners Kockázati Tőkealap-kezelő Zrt-re ruházta. Az alapkezelő 2017-ben tett közzé adatokat a befektetéseiről, amelyek szerint két befektetést eszközöltek 934 millió forint, illetve 1,5 milliárd forint értékben (Karsai, 2017b).

Ezt több további körben megvalósult EU és állami forrásokból finanszírozott állami kockázati tőkeprogram követte, amelyek pályázatokon keresztül ruházták az alapok kezelésének jogát privát alapkezelőkre. 2018-ban a GINOP-8.1.3/B-17 program 75 milliárd forintot osztott szét hét nyertes alapkezelö között. A program célja Magyarország perifériális régióiban található cégek finanszírozása volt, amelyek a fenntarthatóság, az okos városfejlesztés, az egészséges társadalom, az információs és kommunikációs technológia, a mezőgazdaság, az intelligens technológiák, a gépipar, a fenntartható környezet és a megújuló technológiák területén állítanak elő innovációt. A magánszektor nyertes alapjai a következők voltak:

1. FINATECH Capital Kockázati Tőkealap-kezelő Zrt. 
2. X-Ventures Alpha Kockázati Tőkealap-kezelő Zrt.

3. Bonitás Befektetési Alapkezelő Zrt.

4. CV Alapkezelő Zrt.

5. Primus Capital Kockázati Tőkealap-kezelő Zrt. (Solus Capital)

6. DBH Investment Kockázati Tőkealap-kezelő Zrt.

7. X-Ventures Béta Kockázati Tőkealap-kezelő Zrt.

Ugyanekkor a VEKOP-2.1.2-17 ${ }^{4}$ program 5,13 milliárd forintos uniós forrást biztosított a magánszektor egy alapkezelöjének - a Gran Private Equity-nek -, hogy az a GINOP-8.1.3/B-17 által is támogatott iparágakba fektessen be, ám ezek a cégek Közép-Magyarországon is müködhettek (Prim Online, 2018).

\subsubsection{A magyarországi Jeremie program értékelése}

A Jeremie program magyarországi kockázati tőkepiacra gyakorolt hatásainak értékeléséhez (3. kérdés) többféle megközelítést lehet alkalmazni. Egyrészt tekinthetjük az általános kockázati tőkebefektetési tevékenységet és a Jeremie-alapok részarányát a befektetésekben a program időtartama alatt (2009-2016), hogy lássuk, hogyan befolyásolta a kockázati tőke kínálatát. A befektetési tevékenység nyilvánosan elérhető adatforrásai közé tartozik az Invest Europe és a HVCA (utóbbi csak 2014-től kezdte meg a statisztikai adatjelentések közzétételét).

A korábban bemutatott 15. ábra azt mutatja, hogy a 2008-as pénzügyi válság következtében a magyar piacon nagyon gyenge magvető és startup fázisú kockázati tőkés tevékenység folyt. A Jeremie program beindításával a kockázati tőkepiac felgyorsult, 2012-ben elérte befektetési tevékenységének csúcspontját. A 2013-as visszaesés után a kockázati tőkés aktivitás stabil maradt 2014 és 2016 között. Érdekes módon a magvető fázisú befektetési aktivitás továbbra is alacsony szinten maradt, a fejlődés sokkal nyilvánvalóbb volt a startup piacon.

A program utolsó három évét vizsgálva Magyarországon elmondható, hogy évente mintegy 100 befektetés történt 2014-2016 között - lásd a 26. táblázatot. A Jeremie alapok részesaránya ezen befektetéseken belül évről évre nőtt, 50\%-ról 84\%ra.

4 A GINOP-8.1.3/B-17 és VEKOP-2.1.2-17 programok az eredeti Jeremie program folytatásaként voltak számontartva, ezért “Új Jeremie”-nek vagy “Jeremie 2.0”-nak hívták őket a kutatók (Karsai, 2020) 
26. táblázat. Az összes befektetés száma és a Jeremie Alapok részaránya

\begin{tabular}{|l|c|c|c|}
\hline Év & $\mathbf{2 0 1 4}$ & $\mathbf{2 0 1 5}$ & $\mathbf{2 0 1 6}$ \\
\hline Összes befektetés száma & 96 & 109 & 94 \\
\hline Jeremie aránya & $50 \%$ & $61 \%$ & $84 \%$ \\
\hline
\end{tabular}

Forrás: HVCA $(2014,2015,2016)$

Ebből arra következtethetünk, hogy a Jeremie program jelentős mértékben hozzájárult a magyarországi kockázati tőkebefektetési tevékenységhez, így az $1 b$ propozíció - „A Jeremie program lefolyása során növelte a kockázati tőkebefektetési tevékenységet Magyarországon” - támogatásra talált. Ez azonban nem az egyetlen mérőszám, amely alapján a program megítélhető. Azt is meg kell vizsgálnunk, hogy a program elérte-e céljait.

A program egyik célja a regionális fejlesztés volt, a résztvevő alapkezelők többségének Magyarország periférikus régióiban kellett volna befektetnie. Lovas és Illés (2018) a program során befektetéseket elnyerő céltársaságokról gyüjtött adatokat elemezték. Megállapították, hogy az alapok olyan cégekbe fektettek be, amelyek központja bár periférikus régiókban található, de tényleges müködésük a fővárosban zajlik. Ez aláássa a periférikus régiók megerősítéséről szóló eredeti célt, ezért az 1c propozíció - „A Jeremie program sikeresen elérte regionális fejlesztéssel kapcsolatos célját” - nem talált támogatásra. Ezen kívül az alapok köztudottan olyan vállalatokba fektettek be, amelyek kezdetben is magas értékesítési aktivitással rendelkeztek, hogy azonnal teljesítsék a meghatározott értékesítési volumenhez kötött exit feltételét. Ez oda vezetett, hogy a leginkább finanszírozásra szoruló cégek (magvető fázisú társaságok) kevesebbet kaptak a tervezettnél, így az $1 d$ propozíció „A Jeremie program sikeresen finanszírozta a befektetést legjobban igénylö korai fázisú cégeket” - sem talált támogatásra. Végül az alapkezelők szinte mindegyike többségi részesedést szerzett a céltársaságokban, ami csökkentheti az alapító tagok hosszú távú motivációját (Lovas \& Illés, 2018). A Jeremie alapokból befektetéseket nyert cégek adatait elemezve Fazekas és Becsky-Nagy (2019) megállapította, hogy az ügynökköltségek miatt negatív kapcsolat áll fenn a cég növekedése és a kockázati tőkealap-kezelő tulajdoni részesedése között, ami szintén megerősíti, hogy a céltársaságok többségi részvényeinek megszerzése csökkenti az alapítók motivációját. Ha a befektetéseket szakaszonként nyújtanák mérföldkövekhez kötve, amelyeket a célvállalatnak teljesítenie kell, akkor ez a célvállalatokat a befektetési 
időszak alatt teljesítésére ösztönözné, ugyanakkor korlátozná a befektető részesedését is (Századvég, 2016).

Fazekas (2018) megállapította, hogy az állami kockázati tőkealapból (amit állami alapkezelő is kezel) közvetlenül finanszírozásban részesülő vállalatok jobban teljesítettek az értékesítés és a foglalkoztatás növelése tekintetében, mint azok, amelyek a JEREMIE alapból (tehát magánszektorbeli alapkezelő által kezelt alapból) kaptak támogatást, ami azt jelzi, hogy a magánbefektető motivációja nem feltétlenül vezet jobb vállalati teljesítményhez. Ez részben azzal magyarázható, hogy az alapkezelési díj az alapok nagyságához van kötve, és nem az alapok teljesítményéhez. A jövőbeni programokban a teljesítményhez kötött alapkezelési díj további motivációt jelenthet (Századvég, 2016). Kállay és Jáki (2019) azt is megállapította, hogy a céltársaságok teljesítménye nem nőtt a Jeremie-től kapott finanszírozás megszerzése után. Ezen bizonyítékok tekintetében a Jeremie program céltársaságokra gyakorolt hatásai vegyesnek tünnek - bizonyosan növelték rendelkezésre álló tőkéjüket, ám az ügynökproblémák és a befektetők által megszerzett többségi részesedés bizonyosan aláásta a befektetések hatékonyságát az értékesítési és foglalkoztatási növekedést tekintve, így az le propozíció - „A Jeremie program pozitív hatással volt a céltársaságokra” - részben talált csak támogatásra.

A kiválasztási folyamatot a Jeremie program mérete is hátráltatta. Fazekas és Becsky-Nagy (2018) arra a következtetésre jutottak, hogy a program által generált kockázati tőkekínálat messze felülmúlta az ilyen befektetések iránti indokolt igényt, ami nehézségeket okozott a megfelelő pályázókat kiválasztó alapkezelők számára. Hozzáteszik, hogy fontos megkülönböztetni a kockázati tökebefektetésre vágyó céltársaságokat azoktól, amelyek hatékonyan is tudják használni a kockázati tőkebefektetéseket. Szerintük a jövőbeli állami kockázati tőkeprogramok méretének visszafogásával ez a probléma megoldható lenne, és nagyobb volna az esély arra, hogy csak azokat a társaságokat válasszák ki az alapkezelök, amelyek hatékonyan tudják használni a befektetést. Egy másik cikkben arra a következtetésre jutottak, hogy általánosságban a morális kockázat rosszabb eredményhez vezethet az államimagán hibrid kockázati tőkebefektetések esetében, mint a tisztán állami kockázati tőke esetében (Fazekas és Becsky-Nagy, 2020).

További morális kockázati problémák is azonosításra kerültek, például az érdekellentétek az alap tulajdonosai és kezelői, valamint a céltársaságok tulajdonosai és vezetői között. Egyes esetekben a céltársaságoknak fizetniük kellett az alapok 
tulajdonosainak tulajdonában lévő más vállalatok által nyújtott szolgáltatásokért. A pályázók az alap tulajdonosainak személyes ismerősei közül származtak, és a pályázó hozampotenciálját nem támasztotta alá a benyújtott üzleti terv. Ezenkívül az egész program felügyelete és monitorozása igen hiányos volt. A program szabályozásaival kapcsolatban további nehézségek merültek fel. A befektetés nagysága gyakran az alap feltételeinek, nem a céltársaságok igényeinek függvénye volt. Az uniós szabályozás miatt az alapok nem tudtak olyan alapítót kivásárolni, amely inaktívvá vált, vagy akinek az érdekei változtak a befektetési időszak alatt. A céltársaságok üzleti tervei nem feleltek meg a befektetés nagyságának, de mégis elfogadták őket. Voltak esetek, amikor a céltársaság kiszervezte müködését, és valójában nem működtette a projektet, amelyre a beruházást megadták (Deloitte Zrt., 2016).

A hatékonysággal kapcsolatos kérdések ellenére kijelenthetjük, hogy a magyar állam jelentős szerepet játszik a kockázati tőkepiacon, és nagyon aktív résztvevőnek számít. Kétségtelen, hogy nagyban befolyásolja a piacot.

\subsubsection{A Jeremie program összehasonlítása nemzetközi tapasztalatokkal}

A kockázati tőkepiacon történő különböző típusú állami beavatkozásokról szóló szakirodalom alapján meghatározásra kerültek a legjobb gyakorlatok, amelyekből a relevánsak mentén értékelésre kerül a Jeremie program kivitelezése, ami útmutatást nyújthat a döntéshozóknak a jövőbeli programokhoz (4. kérdés).

1. Az első bevált gyakorlat ahhoz kapcsolódik, ahogyan az állam a magán alapkezelőkben képviseli magát. A Jeremie program közvetett állami beavatkozás volt, és egyfajta állami-privát kockázati tőkés partnerség, amelyben az állam biztosította a tőke nagy részét és irányelveket adott meg a befektetésekhez, de nem vett részt a befektetési döntéshozatali folyamatban. Amint azt az előző alfejezet kiemelte, a kutatók között aggályok merültek fel a magánbefektetők kiválasztási folyamatával kapcsolatban, ideértve a morális kockázatot és a befektetési kiválasztás irányelveinek kijátszását. Fontos megemlíteni Brander és szerzőtársai (2015) tanulmányát, akik világszintű adatbázist használva megállapították, hogy az állami befektetők jelenléte ezekben a partnerségi kapcsolatokban segítheti a leendö portfóliócégek kiválasztását a tisztán privát kockázati tőkebefektetésekhez képest. Az állam számára a jövőbeni kockázati tőkeprogramok alapkezelőinek döntéshozó 
bizottságaiba vagy igazgatótanácsaiba néhány tag delegálása monitoring eszközként szolgálna, amely segítségével a befektetési kiválasztási folyamatot ellenőrzés alatt tarthatná és annak során a befektetési irányelveket betartathatná. Amint Grilli és Murtinu (2014) rámutatott, a privát partnernek továbbra is vezető szerepet kell betöltenie annak érdekében, hogy a partnerség pozitív hatást gyakoroljon a portfólió társaságokra. Az állam kontrollt gyakorló jelenléte azonban megakadályozhatja, hogy befektetésben részesüljenek azon céltársaságok, amelyeknek csak a székhelye található a befektetés által megcélzott régióban, de valójában a fővárosban müködnek. Frenkel és szerzőtársai (2008) szintén hangsúlyozták, hogy az állami beavatkozást főként a perifériális régiókra kell korlátozni.

2. A szakirodalom elemzése alapján a másik fó javaslat, hogy az államnak kiegészítenie kell a magánszektort, és nem versenyeznie vele (Gill, 2015; Wonglimpiyarat, 2011; Bauer és Burghof, 2007). A Jeremie program elméletileg megfelelt ennek a javaslatnak, mivel az állam közvetett módon avatkozott be, és megpróbálta a magánbefektetőket cselekvésre ösztönözni. A program tényleges kivitelezése nyomán azonban sok magán kockázati tőkebefektető elégedetlen maradt. Karsai (2016) felmérése rávilágított, hogy a megkérdezett magán kockázati tőkebefektetők többsége bírálta az alapkezelők kiválasztási folyamatának átláthatóságát, és úgy érezte, hogy a nyertes alapkezelőknél hiányzik a szükséges szakértelem, ezért az If propozíció - „A Jeremie program gyöztes alapkezelöinek kiválasztása átlátható folyamat volt” - nem talált támogatásra. Ily módon az állam talán akaratlanul is nagyobb versenyt generált azon privát kockázati tőkéseknek, akik nem voltak a nyertesek között, de rendelkeztek a céltársaság sikeres kiválasztásához szükséges képességekkel. Fontos konzultálni a magánszférával a következő kockázati tőkeprogram elindítása előtt, illetve javítani az alapkezelők kiválasztási folyamatának átláthatóságát. Fazekas és Becsky-Nagy (2018) rámutatott, hogy mivel a kockázati tőke iránt nem volt akkora kereslet, mint kínálat, a jövőbeli programok méretének csökkentése jobb befektetésekhez vezethet. Ezen kívül a leépítés korlátozná azt a mesterségesen létrehozott versenyt is, amellyel a programon kívüli magán kockázati tőkebefektetőknek szembe kell nézniük.

3. A harmadik fó javaslat az, hogy az állami programok ne versenyezzenek egymással (Cumming és Johan, 2009; Tucker et al., 2011; Wonglimpiyarat, 
2011). A Jeremie időtartama alatt több állami kockázati tőkealap-kezelő is müködött több csak állami forrást tartalmazó alapot kezelve (lásd a következő alfejezetet). Nyilvánvaló, hogy a közvetlen (állami alapkezelő társaságok) és a közvetett (Jeremie program) beavatkozások egymással párhuzamosan futottak. Amint arról korábban szó esett, a Jeremie program egyik célja a regionális fejlesztés volt, ennek érdekében a Jeremie alapoknak a fővároson kívüli székhellyel rendelkező cégekbe kellett volna befektetniük. Mivel az állami alapkezelő társaságok befektetési politikája ily módon volt korlátozva, ez csökkenthette volna a Jeremie program és az állami kockázati tőkealap-kezelök közötti versenyt. Mivel azonban még a Jeremie program céltársaságai is valójában többnyire a főváros technológiai központjában müködtek, a valóságban verseny folyt ezen állami kezdeményezések között.

4. Végül Karsai (2017a) a közép-kelet-európai állami programokat elemezte, és megfogalmazott egy javaslatcsomagot, amelyeket ezen országok államainak követniük kellene jövőbeni kockázati tőkeprogramjaik strukturálásakor. Nevezetesen: a program időtartamának rövidnek kell lennie a piac lehető legkisebb befolyásolása érdekében, a bürokratikus követelményeket minimalizálni kell, a programokat nem szabad túlszabályozni, és a program folyamán adatokat kell gyüjteni annak érdekében, hogy azok végén teljes értékelést lehessen véghez vinni. A Jeremie program nem felelt meg ezeknek a javaslatoknak. Az összes bizonyítékot tekintve nem talált támogatásra az $1 g$ propozíció - A Jeremie program kivitelezése követte a legjobb nemzetközi gyakorlatokat.

\subsection{Közvetlen állami beavatkozás}

Ebben az alfejezetben a magyar állam közvetlen beavatkozásait vizsgáljuk a kockázati tőkepiacon (5. kérdés). A közvetlen beavatkozás azt jelenti, hogy az állam tulajdona az alapkezelő, amely az állam által biztosított forrásokat (alapokat) kezeli. A HVCA nyilvántartása szerint 2020-ban 26 befektetési társaság működik a magyar kockázati tőkepiacon, és közülük három állami tulajdonban van: a Széchenyi Tőkealap-kezelő Zrt. (SZTA), a Hiventures Kockázati Tőkealap-kezelő Zrt. (előzőleg: Corvinus Kockázati Tőkealap-kezelő Zrt. - CKTA), és az MFB Invest Befektetési és Vagyonkezelő Zrt (MFB Invest). Az MFB Invest Zrt. nem tőkealap- 
kezelő, azonban számos alapban van befektetése és két tőkealap-kezelő 100\%-os tulajdonosa.

A különböző kezelt alapok befektetési politikáját áttekintve meghatározható, hogy milyen nemzeti stratégiai célokat tartanak szem előtt (6. kérdés). A fejezet a COVID-19 járványra közvetlen beavatkozási módszerekkel adott állami válasz feltérképezésével zárul (7. kérdés).

\subsubsection{MFB Invest által tulajdonolt alapok és tőkealap-kezelők}

Az MFB Invest-en keresztül a Magyar Fejlesztési Bank több alapba eszközölt befektetést, amelyeket különböző alapkezelők menedzselnek. Az MFB Invest Befektetési és Vagyonkezelő Zrt. tehát az alapok befektetési jegyeit tulajdonolja, illetve kockázati tőkealap kezelőknek 100\%-os tulajdonosa, azonban jogi értelemben nem kockázati tőkealap-kezelő társaság (annak ellenére, hogy a HVCA-nál bejegyzésre került). A Focus Ventures Kockázati Tőkealap-kezelő Zrt.-n és a Hiventures Kockázati Tőkealap-kezelő Zrt.-n (mindkettő az MFB Invest 100\%-os leányvállalata - MFB Invest, 2020a) keresztül valósul meg a közvetlen állami beavatkozás, mivel ezek kizárólag állami forrásokat tartalmazó alapokat kezelnek. Másrészt az MFB Invest Zrt. befektet olyan alapokba is, amelyeket privát alapkezelő társaságok menedzselnek, tehát közvetett beavatkozás is történik az MFB Invest Zrt.n keresztül. Az alábbi táblázat szemlélteti az MFB Invest alapjait.

27. táblázat: Az MFB Invest Befektetési és Vagyonkezelő Zrt.

\begin{tabular}{|c|c|c|c|c|}
\hline Alap neve & $\begin{array}{l}\text { Alap } \\
\text { mérete }\end{array}$ & Befektetési célok & Tulajdonosok & Alap kezelője \\
\hline $\begin{array}{c}\text { Enter Tomorrow } \\
\text { Kockázati } \\
\text { Tőkealap }\end{array}$ & $\begin{array}{l}50 \\
\text { millió } \\
\text { EUR }\end{array}$ & $\begin{array}{l}\text { nagy növekedési } \\
\text { potenciállal } \\
\text { rendelkezó érettebb } \\
\text { vállalkozások }\end{array}$ & $\begin{array}{l}\text { MFB Invest és } \\
\text { MOL Nyrt. }\end{array}$ & $\begin{array}{c}\text { LEAD } \\
\text { Ventures } \\
\text { Alapkezelő Zrt. }\end{array}$ \\
\hline $\begin{array}{c}\text { IMPACT } \\
\text { Ventures } \\
\text { Magántőkealapok } \\
\text { (I-II.) }\end{array}$ & $\begin{array}{l}6,25 \\
\text { md. Ft }\end{array}$ & $\begin{array}{l}\text { pozitív társadalmi } \\
\text { hatású vállalkozások }\end{array}$ & $\begin{array}{l}\text { MFB Invest, } \\
\text { European } \\
\text { Investment } \\
\text { Fund, Optima } \\
\text { Befektetési } \\
\text { Zrt., Impact } \\
\text { Ventures } \\
\text { Team Kft. }\end{array}$ & $\begin{array}{l}\text { IMPACT } \\
\text { Ventures } \\
\text { Kockázati } \\
\text { Tőkealap- } \\
\text { kezelő Zrt. }\end{array}$ \\
\hline $\begin{array}{l}\text { Divat\&Design } \\
\text { Tőkealap }\end{array}$ & $\begin{array}{l}5 \mathrm{md} . \\
\mathrm{Ft}\end{array}$ & $\begin{array}{c}\text { innovatív, nagy } \\
\text { növekedési } \\
\text { potenciállal } \\
\text { rendelkező divat és } \\
\text { design szektorba } \\
\text { tartozó vállalkozások }\end{array}$ & MFB Invest & $\begin{array}{l}\text { Hiventures } \\
\text { Kockázati } \\
\text { Tőkealap- } \\
\text { kezelö Zrt. }\end{array}$ \\
\hline
\end{tabular}




\begin{tabular}{|c|c|c|c|c|}
\hline $\begin{array}{c}\text { Chi Fu } \\
\text { Hungarian } \\
\text { Economy } \\
\text { Opportunity } \\
\text { Fund }\end{array}$ & $\begin{array}{l}200 \\
\text { millió } \\
\text { EUR }\end{array}$ & $\begin{array}{c}\text { nagyobb } \\
\text { magántőkebefektetést } \\
\text { igénylő vállalatok }\end{array}$ & $\begin{array}{l}\text { MFB Invest és } \\
\text { Chi Fu } \\
\text { Investment } \\
\text { Group }\end{array}$ & $\begin{array}{c}\text { Chi Fu } \\
\text { Investment } \\
\text { Management } \\
\text { Zrt. }\end{array}$ \\
\hline $\begin{array}{c}\text { Water Impact } \\
\text { Alap }\end{array}$ & $\begin{array}{l}5 \mathrm{md} . \\
\mathrm{Ft}\end{array}$ & $\begin{array}{l}\text { vízügyi területen } \\
\text { innováló } \\
\text { vállalkozások }\end{array}$ & MFB Invest & $\begin{array}{c}\text { Susterra Capital } \\
\text { Partners } \\
\text { Kockázati } \\
\text { Tőkealap- } \\
\text { kezelő Zrt. }\end{array}$ \\
\hline $\begin{array}{c}\text { Debreceni } \\
\text { Iparfejlesztési } \\
\text { Alap }\end{array}$ & $\begin{array}{c}15 \mathrm{md} . \\
\mathrm{Ft}\end{array}$ & $\begin{array}{l}\text { ipari parkok } \\
\text { fejlesztése } \\
\text { Debrecenben }\end{array}$ & $\begin{array}{l}\text { MFB Invest és } \\
\text { XID } \\
\text { Befektetési } \\
\text { Zrt. }\end{array}$ & $\begin{array}{c}\text { XANGA } \\
\text { Ventures } \\
\text { Magántőkealap- } \\
\text { kezelö Zrt. }\end{array}$ \\
\hline Városi Alapok & $\begin{array}{l}2-10 \\
\text { md. Ft } \\
\text { / alap }\end{array}$ & $\begin{array}{c}\text { bizonyos } \\
\text { magyarországi } \\
\text { városok érett és } \\
\text { innovatív } \\
\text { vállalkozásai }\end{array}$ & MFB Invest & $\begin{array}{l}\text { Focus Ventures } \\
\text { Kockázati } \\
\text { Tőkealap- } \\
\text { kezelő Zrt. }\end{array}$ \\
\hline
\end{tabular}

Forrás: saját szerkesztés az MFB Invest adatai alapján (2021)

A nyereségszerzés mellett a Focus Ventures Kockázati Tőkealap-kezelő Zrt célja a regionális fejlesztés az úgynevezett „városalapok”-on keresztül, amelyek kizárólag egy kijelölt városban történő befektetés céljából létrehozott alapok. Eddig három alapot hoztak létre Debrecen, Székesfehérvár és Kaposvár városok számára, (MFB Invest, 2020b). Ez garantálja, hogy a befektetés kizárólag az adott területen történik meg, és nem kerül mégis fövárosi tevékenységü cégekhez (lásd Jeremie program). Az állam így a kockázati tőkepiacon a befektetés általi pozitív externália, jelen esetben a regionális fejlesztés előidézése érdekében avatkozik be. Ezen alapok másik célja a SARS-CoV-2 (vagy koronavírus) járvány negatív gazdasági hatásainak enyhítése. Az alapok nagysága 10 milliárd forint a debreceni városi alap (MFB Invest, 2020c), 5 milliárd forint a székesfehérvári városi alap (MFB Invest, 2020d), és 3 milliárd forint a kaposvári városi alap (MFB Invest, 2020e) esetében. Az MFB Invest 2019-ben a Water Impact alapba is befektetett, ezt a Susterra Capital Partners Kockázati Tőkealap-kezelő Zrt. kezeli (közvetett beavatkozás), amely olyan magyar, közép-kelet-európai és DACH-régióbeli cégekbe fektet be, amelyek innovatív megoldásokat dolgoznak ki a vízfelhasználás hatékonyságának javítása érdekében, és hozzájárulnak a világ vízellátási problémáinak megoldásához (MFB Invest, 2019). Ez egy újabb példa arra, ahogy az állam finanszírozást nyújt vállalatoknak pozitív társadalmi célok megfontolásából (,social impact”), amely a pozitív externáliák egy másik formája. A 2 c propozíciót - A hazai közvetlen állami beavatkozás stratégiai céljai közé tartozik a pozitív externáliát termelö cégek finanszírozása - támogatja, 
hogy ezen alapok nemzeti stratégiai célokat mozdítanak elő, amelyek pozitív externáliaként jelennek meg a finanszírozás során, mint a regionális fejlesztés, a foglalkoztatás növelése, a fenntarthatóság és a pozitív társadalmi hatás.

\subsubsection{Hiventures Kockázati Tökealap-kezelö Zrt. (jogelödje: CKTA)}

A Corvinus Kockázati Tőkealap-kezelő (CKTA) 1999-ben alakult, majd 2016ban Hiventures névre keresztelték át és jelentős állami tőkealapok kezelésével bízták meg. A 2014-2020-as programozási időszak keretében az alapkezelő 50 milliárd Ft finanszírozást kapott az inkubációs, magvető és növekedési stádiumú vállalkozásokba történő befektetésre. Ezeknek a befektetési területeknek a mérete 10 milliárd forint volt az inkubációs, 16 milliárd a magvető és 24 milliárd a növekedési fázis esetében. A Hiventures kezdeti célja olyan vállalatok finanszírozása volt, amelyek finanszírozását a magánszektor kockázati tőkebefektetői túl kockázatosnak találják, illetve a startup ökoszisztéma fejlesztése. Finanszírozását később 80,4 milliárd forintra növelték, mivel a Hiventures-t több állami kockázati tőkeprogram kezelésére választották ki: GINOP-8.1.3/A-16, GINOP-8.2.3-17 és GINOP-8.2.5-17. Ilyen nagy méretnél látható, hogy az állam közvetlen módon folytatta korábbi közvetett kockázati tőkeintervencióját (a Jeremie programot) azzal, hogy a Hiventures-t nevezte ki az állami források kezelésére, így a $2 b$ propozíció - „A hazai állam fókuszát a közvetett beavatkozásról a közvetlen beavatkozásra helyezte át a Jeremie programot követöen" - támogatásra talált. Az inkubációs fázisú befektetések nagysága kezdetben 9 millió forint volt, a magvető fázisú befektetéseké 65-250 millió forint, a növekedési fázisúaké 250-1000 millió forint. Később a befektetési összegeket megemelték az inkubációnál 15-65 millió forintra és a magvetőnél 65-500 millió forintra. Átstrukturálásától és 2016. augusztusi beindításától 2018 végéig a Hiventures több, mint 2000 befektetési javaslatot vizsgált meg, 204 vállalatba fektetett be összesen 17 milliárd forintos befektetési volumennel. 122 inkubációs fázisú cég kapott összesen 2,4 milliárd forintnyi befektetést, 48 magvető fázisú összesen 5,3 milliárd forintnyit, illetve 34 növekedési fázisú cég összesen 9,5 milliárd forintnyit (Hiventures, 2019). Az alapkezelő nem fektethet be olyan vállalatokba, amelyek negatív externáliákat generálhatnának, például kaszinókba, fegyvergyártó cégekbe, pornográfiával vagy prostitúcióval foglalkozó vállalatokba (Palyazat.gov.hu, 2017). Ez is megerősíti azt, hogy az állami kockázati 
tőkebefektetők pozitív externáliákat kibocsátó vállalatokba fektetnek be, és tilos befektetniük negatív externáliát generáló cégekbe.

A társaság túlnyomórészt állami forrásokat fektet be, de 18 befektetésbe sikerült bevonnia egy társbefektetőt is a magánszektorból, 2,2 milliárd forint magánbefektetéssel. Az alapkezelő közölte, hogy a portfóliójában található társaságok átlagosan 85\%-os árbevétel-növekedést realizáltak a befektetés közvetlen következményeként (Hiventures, 2018). Az SZTA-hoz hasonlóan a Hiventures is csak kisebbségi részesedést szerezhet a céltársaságokban első körös befektetés esetén, viszont a céltársaságok érésük és fejlödésük során több fordulóban kaphatnak finanszírozást a Hiventures-től, amely során a megszerzett tulajdoni részesedés már meghaladhatja az 50\%-ot (de 80\% alatt kell, hogy maradjon). Ha a társaság különösen nyereségessé válik, akkor az alap részesedését is visszavásárolhatja, de más kilépési lehetőségek is nyitottak, ideértve a harmadik félnek történő közös értékesítést vagy az tőzsdére lépést (Palyazat.gov.hu, 2017). Így az állami kockázati tőkebefektetők befektetési szerkezete alapvetően különbözik a privát kockázati tőkebefektető társaságokétól (lásd: 5.5.4 alfejezet).

A Hiventures 2019-ben egy KKVPRO néven befektetési üzletágát is elindította, amely egy 31 milliárd forintos alapot kezel bejáratottabb, érettebb, legalább 300 millió forintos árbevétellel rendelkező, finanszírozásért folyamodó kkv$\mathrm{k}$ támogatásának céljából. E befektetések hátterében az állhat, hogy támogatni kívánják a családi tulajdonban lévő vállalkozások tulajdonjogának a menedzsmentre vagy a harmadik féltől származó hazai befektetőre való átruházását, finanszírozást kívánnak nyújtani a kkv-k egyesüléseihez és felvásárlásaihoz, valamint a kkv-k nemzetközi terjeszkedését kívánják támogatni. Ezen befektetések nagysága 50 millió és 3,1 milliárd forint között mozog, és az alap kisebbségi tulajdonban marad a céltársaságban. A nemzetközi terjeszkedési célok közé tartozik a külföldi cégek felvásárlása, ami növeli az országba érkező bevételeket - ez egy nemzeti stratégiai cél (Hiventures, 2019).

Összefoglalva: 2007 és 2016 között az állami kockázati tőkebefektetések domináltak a piacon közvetett beavatkozás (Jeremie program) és közvetlen intervenció (Széchenyi Tőkealap-kezelő) formájában; a két kezdeményezés az országban végrehajtott összes kockázati tőkebefektetés háromnegyedét adta a 20072016 közötti időszakban (Karsai, 2017b). 2017 óta az SZTA befektetéseinek 
volumene csökkent (lásd 29. táblázat), és a Hiventuresé lett a vezető szerep állami kockázati tőkefinanszírozás elosztásában.

\subsubsection{Széchenyi Tökealap-kezelö Zrt.}

Az SZTA 2011. június 1-én alakult meg. Annak ellenére, hogy kockázati tőkealap-kezelő cég, az SZTA későbbi életszakaszban lévő társaságokba is végrehajt befektetéseket. Az SZTA finanszírozását 85\%-ban az EU, 15\%-ban az állam biztosítja, hasonlóan a Jeremie programhoz (Fazekas és Becsky-Nagy, 2018). Megalakulása óta az SZTA 120 befektetést és több, mint 40 exitet hajtott végre. Az SZTA a következő alapokat kezeli.

28. táblázat: A Széchenyi Tőkealap-kezelő Zrt.

\begin{tabular}{|c|c|c|}
\hline Alap neve & Alap mérete & Befektetési célok \\
\hline Széchenyi Tőkebefektetési Alap & $22 \mathrm{md}$. forint & innovatív hazai kkv-k \\
\hline Irinyi I. Kockázati Tőkealap & $\begin{array}{c}7,47 \mathrm{md} . \\
\text { forint }\end{array}$ & $\begin{array}{c}\text { ipari innovációt végrehajtó kkv-k a } \\
\text { hazai perifériális régiókban }\end{array}$ \\
\hline Irinyi II. Kockázati Tőkealap & $8 \mathrm{md}$. forint & $\begin{array}{c}\text { ipari innovációt végrehajtó kkv-k } \\
\text { Közép-Magyarországon }\end{array}$ \\
\hline $\begin{array}{c}\text { Kárpát-Medencei } \\
\text { Vállalkozásfejlesztési Kockázati } \\
\text { Tőkealap }\end{array}$ & $20 \mathrm{md}$. forint & $\begin{array}{c}\text { nemzetközi növekedési } \\
\text { potenciállal rendelkező mikro-, } \\
\text { kis- és középvállalkozások }\end{array}$ \\
\hline Nemzeti Tőzsdefejlesztési Alap & $13 \mathrm{md}$. forint & $\begin{array}{c}\text { IPO-val tőzsdei belépést célzó } \\
\text { kkv-k }\end{array}$ \\
\hline $\begin{array}{c}\text { Kék Bolygó Klímavédelmi Kockázati } \\
\text { Tőkealap }\end{array}$ & $10 \mathrm{md}$ forint & $\begin{array}{c}\text { fentarthatóság, tiszta energia, } \\
\text { fenntartható vízügyi megoldások, } \\
\text { klímavédelem területén innováló } \\
\text { kkv-k }\end{array}$ \\
\hline
\end{tabular}

Forrás: saját szerkesztés az SZTA adatai alapján (2020)

Az SZTA különféle stratégiai célok elérésére törekvő alapokat kezel: ilyenek az innováció támogatása, a periféria fejlesztése, az ipari innováció támogatása, a kkv-k támogatása a nemzetközi piacra lépésben, az elismertebb kkv-k tőzsdére lépésének támogatása, sőt, a fenntarthatóság támogatása is. A Kék Bolygó Klímavédelmi Kockázati Tőkealap egy újabb példa az olyan állami kockázati tőkés kezdeményezésre, amelynek célja a pozitív externáliákat kibocsátó kkv-k támogatása, ideértve a fenntarthatósági, a klímavédelmi és a tiszta energiával kapcsolatos innovációt, valamint a fenntartható vízügyi megoldásokat. Az SZTA társbefektetőket von be az Irinyi alapokból (GINOP-8.3.3-17 kockázati tőkeprogram) és a Nemzeti Tőzsdefejlesztési Alapból eszközölt befektetések esetében, ami hibrid 
finanszírozási modell jellegzetességet mutat. Standaert és Manigart (2018) megállapította, hogy a közös állami-privát formában befektetésben részesülö vállalatok nagyobb foglalkoztatottsági növekedést mutatnak, mint azok a vállalatok, amelyek kizárólag állami vagy magán tőkebefektetéseket kaptak. Az előző fejezet rámutatott más tanulmányokra, amelyek a hibrid állami-privát finanszírozás pozitív hatásait írták le. Ezek alapján az SZTA jó irányba halad, és társbefektetési rendszerének kibővítése jelentheti a megoldást az állami kockázati tőkebefektetések problémáira.

29. táblázat: A Széchenyi Tőkealap-kezelő Zrt. befektetési tevékenysége

\begin{tabular}{|c|c|c|c|c|c|c|c|c|}
\hline Év & $\mathbf{2 0 1 2}$ & $\mathbf{2 0 1 3}$ & $\mathbf{2 0 1 4}$ & $\mathbf{2 0 1 5}$ & $\mathbf{2 0 1 6}$ & $\mathbf{2 0 1 7}$ & $\mathbf{2 0 1 8}$ & $\mathbf{2 0 1 9}$ \\
\hline $\begin{array}{c}\text { Az SZTA által } \\
\text { eszközölt befektetések } \\
\text { Száma }\end{array}$ & 13 & 17 & 30 & 25 & 11 & 0 & 9 & 6 \\
\hline $\begin{array}{c}\text { Az SZTA által } \\
\text { eszközölt befektetések } \\
\text { volumene, ezer euróban }\end{array}$ & 3110 & 5389 & 15227 & 11939 & 6100 & 0 & 5331 & 4426 \\
\hline $\begin{array}{c}\text { A magyarországi összes } \\
\text { kockázati } \\
\text { tőkebefektetés teljes } \\
\text { volumene, ezer euróban } \\
\text { (az Invest Europe } \\
\text { adatbázisa) }\end{array}$ & 66819 & 18376 & 29902 & 23798 & 28940 & 37837 & 70623 & 120814 \\
\hline $\begin{array}{c}\text { Az SZTA kockázati } \\
\text { tókebefektetéseinek } \\
\text { részaránya a teljes } \\
\text { magyarországi kockázati } \\
\text { befektetési volumenen } \\
\text { belül }\end{array}$ & $4,65 \%$ & $29,32 \%$ & $50,92 \%$ & $50,17 \%$ & $21,08 \%$ & $0,00 \%$ & $7,55 \%$ & $3,66 \%$ \\
\hline
\end{tabular}

Forrás: SZTA (2020), Invest Europe (2017), Invest Europe (2020)

A fenti táblázat alapján az állami tulajdonú SZTA alapkezelő élettartama alatt mindeddig jelentős részarányt képviselt a magyarországi összes kockázati tőkés befektetésen belül. 2014-ben és 2015-ben a befektetett töke felét biztosította, azonban részaránya csökkent az utóbbi években. A legfontosabb közvetett kockázati tőkeprogram, a Jeremie időtartama alatt az állam jelenléte még mindig igen jelentős volt a magyar kockázati tőkepiacon, így a 2 a propozíció - „A hazai állam a Jeremie program lefolyása során közvetlen módon is beavatkozott a kockázati tökepiacon”támogatásra talált. A Századvég (2016) szerint az alapkezelő indulásakor csak a Széchenyi Tőkebefektetési Alapot kezelte kisebb méretü, legfeljebb 750 ezer euró értékü befektetéseket kínálva azzal a szándékkal, hogy ne versenyezzen a Jeremie programmal. Mivel az állami beavatkozás leginkább a magvetés előtti és az magvető fázisú finanszírozási szegmensben indokolható, az SZTA jelenléte jobban volt 
pozícionálva a finanszírozási rés leküzdésére, mint a Jeremie program. Ezenkívül az SZTA csak kisebbségi részesedést szerezhet a céltársaságokban, ami az alapítókat is jobban motiválja cégük értékének növelésére (a Jeremie alapok által a céltársaságokban szerzett elnyomó többségi részesedések kritikáját lásd az előző alfejezetben).

\subsection{4 Állami és privát kockázati tőkebefektetők jellemzőinek eltérése}

A kockázati tőkealapkezelők a tőkeágon fektetnek be. A befektetési szerződésekben meghatározzák a kilépési lehetőségeket, a tulajdonosi jogok gyakorlását, a szavazati jogokat, a testületek, tulajdonosok döntési hatáskörét, valamint a tagok különböző pozíciókba és testületekbe (felügyelöbizottság tagjai, igazgatótanács, vezérigazgató stb.) történő delegálásának/jelölésének jogát. A különbségek azonosítása érdekében először vizsgáljuk meg a privát kockázati befektetések jellemzőit.

A privát kockázati alapkezelő társaságok arra koncentrálnak, hogy a befektetett tőkéért minél nagyobb tulajdonosi részesedést szerezzék a céltársaságban. Ha a céltársaság értékesebbé válik, akkor a befektetők jelentős hozamot érhetnek el az exittel. Ha többségi részesedést szereznek, akkor az irányítási jogokat is megszerzik. Szeretik hangsúlyozni, hogy ők stratégiai befektetők és a befektetéseiket támogatják az üzleti életben meglévő kapcsolati hálóval és piaci know-how-val. Rendszerint ragaszkodnak ahhoz, hogy a szerződésbe foglalják az úgynevezett „drag-along” jogot, amely arra kötelezi az alapítókat, hogy részesedésüket a befektetővel együtt adják el, ha az exit-lehetőséget talált.

Ezzel szemben az állami kockázati tökebefektetők általában pénzügyi befektetők: nem kívánnak beavatkozni a mindennapi müködésbe. Nem feltétlenül szereznek többségi részesedést a céltársaságokban, részesedésük általában $49 \%$ alatt marad. Így a vezetést az eredeti alapítók kezében hagyják (legalább az első befektetési körben). Több befektetési kör során viszont részesedésük átlépheti az 50\%-os küszöböt (és akár a $80 \%$-ot is elérheti). Ha az állami részesedés meghaladja az 50\%-ot, a céltársaság elveszti KKV státuszát az uniós szabályozás értelmében, ez viszont nem akadályozza a befektetést csak tájékoztatni kell róla a céltársaságot (Palyazat.gov.hu, 2016). A befektető tulajdonrészének növekedésével csökken a vállalkozó motivációja (Lovas \& Illés, 2018; Becsky-Nagy, 2019), így javasolt a 
jövőbeli állami kockázati tőkeprogramoknál kikötni, hogy az állami tulajdonrész semmiképp se haladhassa meg az 50\%-ot.

Ezenkívül az állami kockázati tőkebefektetők elöre rögzített opciót kínálnak az alapítók számára a tőkealap befektetési részesedésének kivásárlására, amely korlátozza az egyes befektetéseiken elérhető profitot. Az egyik lehetséges exitlehetőség a vételi opció az alapítók számára: egy elöre rögzített értéken visszavásárolhatják az alapítók az alap részesedését. A tőkebefektetéseket gyakran az exitig folyamatosan visszatörlesztendö tulajdonosi kölcsönnel kombinálják. Ez kockázatcsökkentő lépésnek tekinthető, amely a hibrid finanszírozáshoz hasonlóan alakítja át az állami tökebefektetéseket. Ezeknél a kölcsönöknél alacsonyabb kamatlábat számítanak fel, mint a tőke várható hozama. Ez megteremti a magyar innovatív vállalkozók számára azt a lehetőséget, hogy megalapíthassák cégüket, és a legjobb esetben megtarthassák a tulajdonjogot, az országban maradhassanak (miközben nagy valószínüséggel exporttevékenységet folytatnak), és növeljék a hazai foglalkoztatást és a hazai adóbevételeket. A „drag-along” jog azonban még az állami kockázati tőkebefektetések term sheet-jein is megjelenhet (Pintér, 2021).

\subsubsection{A mentöprogramok jelene és jövője}

A SARS-CoV-2 vírus - közismertebb nevén „koronavírus” - és az általa okozott betegség, a COVID-19 több milliárd ember egészségi állapotát és mindennapi életét forgatta fel világszerte. Mivel a tudósok, az egészségügyi tisztviselők és számos állam úgy gondolta, hogy a közösségi elszigetelődés az egyik legjobb rendelkezésre álló védelmi stratégia a járvánnyal szemben, a kereslet lecsökkent számos termék és szolgáltatás iránt. Ez leginkább a személyes ügyfélforgalomra támaszkodó vállalatokat érintette, mint például az éttermeket, bárokat, mozikat, koncerttermeket, edzőtermeket, turisztikai irodákat stb. A forgalom csökkenésével ezeknek a vállalkozásoknak a bevétele nagymértékben csökkent, és az alkalmazottak megélhetése bizonytalanná vált. Mivel ez tovább csökkentheti az áruk iránti keresletet és negatív visszacsatolási hurkot hozhat létre, elengedhetetlen, hogy a kormányok mentőprogramokkal segítsék a gazdaság fellendítését, és az válság által jobban súlytott ágazatokban működő vállalkozásokat.

A magyar állam 2020. áprilisában az MFB-n keresztül hatalmas mentőakciót indított. A kezdeményezés összesen 1490 milliárd forintot biztosít cégeknek három hitel-, két garancia- és négy tőkeprogram révén. 
A hitelprogramok 439 milliárd forint finanszírozást nyújtanak, és közéjük tartozik az MFB Krízis Hitel, a „KKV Technológia” Hitelprogram és az MFB Versenyképességi Hitelprogram. A vállalatok pénzügyi intézményeken keresztül igényelhetik az MFB Krízis Hitelt legalább 1, legfeljebb 150 millió forint értékben 2,5\%-os kamatláb mellett, amelyet beruházásokra, valamint forgótőke és likviditási finanszírozásra lehet felhasználni. Az MFB Versenyképességi Hitelprogram ugyanezen felhasználási célok, valamint az akvizíciókra való felhasználás mellett nyitva áll a nagyvállalatok számára is. Az állam garanciát vállal a kölcsön összegének 80\%-áért. A „KKV Technológia” Hitelprogram nulla kamatlábbal különbözteti meg magát a többi kezdeményezéstől (Bankár Magazin, 2020).

A tőkeprogramokhoz a kijelölt alapkezelő társaság a Hiventures, kivéve a Krízis Tőkeprogram II-t, amely az ígéret szerint magánszektorbeli alapkezelők számára kiírt pályázat tárgyát képezi majd (erről a programról nincs újabb hír). A programok mérete, a tervezett céltársaságok és a befektetések mérete az alábbi táblázatban látható.

30. táblázat: Állami tőkés mentőcsomagok Magyarországon

\begin{tabular}{|c|c|c|c|}
\hline Program neve & $\begin{array}{c}\text { Program } \\
\text { mérete }\end{array}$ & Céltársaságok & $\begin{array}{c}\text { Befektetés } \\
\text { mérete }\end{array}$ \\
\hline $\begin{array}{c}\text { KKV Mentő } \\
\text { Tökeprogram }\end{array}$ & $\begin{array}{c}41 \mathrm{md} . \\
\text { forint }\end{array}$ & $\begin{array}{c}\text { nehéz helyzetben lévő kkv-k banki } \\
\text { finanszírozási lehetöségek nélkül }\end{array}$ & $\begin{array}{c}50-250 \text { millió } \\
\text { forint }\end{array}$ \\
\hline $\begin{array}{c}\text { Startup Mentő } \\
\text { Tőkeprogram }\end{array}$ & $\begin{array}{c}30 \mathrm{md} . \\
\text { forint }\end{array}$ & $\begin{array}{c}\text { startupok korábbi kockázati } \\
\text { tőkebefektetéssel }\end{array}$ & $\begin{array}{c}65-150 \text { millió } \\
\text { forint }\end{array}$ \\
\hline $\begin{array}{c}\text { Krízis I. } \\
\text { Tőkeprogram }\end{array}$ & $\begin{array}{c}150 \mathrm{md} . \\
\text { forint }\end{array}$ & kkv-k vagy nagyvállalatok & $\begin{array}{c}500 \text { millió }-15 \\
\text { milliárd forint }\end{array}$ \\
\hline $\begin{array}{c}\text { Krízis II. } \\
\text { Tőkeprogram }\end{array}$ & ismeretlen & kkv-k vagy nagyvállalatok & ismeretlen \\
\hline
\end{tabular}

Forrás: saját szerkesztés MFB (2020) alapján

A Hiventures egy hónap alatt helyezi ki a mentőbefektetéseket, míg a normál befektetési folyamatok időtartama általában 4-6 hónap. A Startup Mentő Tőkeprogramban és a KKV Mentő Tőkeprogramban 1\%-os tulajdonrészt kérnek a célvállalkozásokból, amelyet a céltársaság 5,1\%-os elvárt hozam teljesítésével visszavásárolhat, ráadásul tulajdonosi kölcsön is rendelkezésére áll. A Krízis I. Tőkeprogram a közepes méretü és a nagyvállalatokat segíti több célkitűzéshez kapcsolódó magasabb befektetési összeggel. A programoknak három célja van: 
- Elsősorban azok a vállalatok, amelyeket a járvány negatívan érint - és így nem számíthatnak banki kölcsönökre - szerkezetátalakítási céllal forráshoz jussanak, amíg pénzügyi helyzetük ismét rendeződik.

- Másodszor, ez a befektetés segít a stratégiailag fontos vállalatoknak a világjárvány sújtotta cégek felvásárlásában, hogy elkerüljék a külföldi befektetők általi felvásárlást.

- Harmadszor, a program finanszírozza a hazai nagyvállalatok stratégiailag fontos befektetéseit, amelyek hosszú távon bár növelnék a profitabilitásukat, de a jelenlegi helyzetben a bankszektor nem finanszírozná őket (Forbes, 2020).

Ezeket a tőkeprogramokat az állami tulajdonú Hiventures kockázati tőkealapkezelő menedzseli (közvetlen beavatkozás), így a $2 d$ propozíció - „,Az állam közvetlen kockázati tökés beavatkozást alkalmazott a COVID-19 járványra adott válasza során" - támogatásra talált.

Eddig a mentőprogramok hozadékai az olcsó hitelek és az állam által a pénzügyi intézményeken keresztül nyújtott garancia, valamint a Hiventures Zrt.-n keresztül az állami közvetlen beavatkozás a kockázati tőkepiacon. A későbbiekben még megvalósításra kerülhet a Krízis II. Tőkeprogram, amely bevonná a magánszektor alapkezelőit is, hogy azok részt vegyenek az állam által biztosított források kezelésében (közvetett beavatkozás). Azonban a Krízis II. Tőkeprogram- ról a 2020. áprilisi kezdeményezése óta nincs hír, ami megkérdőjelezi, hogy a magánszektor alapkezelői valóban részt vehetnek-e majd.

\section{6 Összefoglalás}

A magyar kockázati tőkepiac fejlődése során több szakasz került azonosításra. A 2008-as gazdasági válság negatív hatásait enyhítette az állam egyre erőteljesebb közvetett és közvetlen részvétele a hazai kockázati tőkepiacon. A közvetett szerepvállalás fő megnyilvánulási formája az EU Jeremie programja volt, amely növelte a kkv-k számára rendelkezésre álló tőkét és segített a piac lendületének visszaszerzésében. A program azonban számos célkitüzésében kudarcot vallott, ideértve a leginkább befektetésre szoruló korai stádiumban lévő vállalatok finanszírozását és a periférikus régiók fejlesztésének célját. A program további kritikákat kapott az alapkezelő kiválasztási folyamatának átláthatatlansága miatt. A program nem követte a szakirodalomban található legjobb nemzetközi gyakorlatokat. 
Az állam a Jeremie programmal párhuzamosan az SZTA alapkezelőn keresztül közvetlenül is beavatkozott. A Jeremie program után a közvetlen szerepvállalás kapott vezető szerepet, az állam széleskörü forrásokat biztosított saját alapkezelőjének, a Hiventures-nek és számos egyéb alapkezelőnek az MFBcsoportban. A Focus Ventures alapkezelő felelős olyan alapok kezeléséért, amelyek csak egy adott hazai városban fektetnek be, hogy a periférikus régiókat fejlesszék, valamint egy, a fenntartható vízügyi megoldásokat támogató alapért. Az SZTA emellett fenntarthatósági és társadalmi hatású alapot is kezel, amely pozitív externáliákat generáló cégekbe történő befektetésekre összpontosít, ami a kockázati tőkepiaci állami beavatkozás egyik indoka. A COVID-19 járványra válaszul az állam mentőprogramokat indított kölcsöntámogatásokkal, bankgaranciákkal és tőkebefektetésekkel. A tőkeprogramok - amelyeket a Hiventures kezel -, befektetéseket biztosítanak induló vállalkozások, kkv-k és nagyobb vállalatok számára, valamint enyhítik a járvány negatív következményeit. Az ígéret szerint az egyik tőkeprogram a magánszektor kockázati tőkés befektetői, mint alapkezelők részvételével valósul majd meg (közvetett beavatkozás), de az erre vonatkozó pályázatot még ki nem hirdették ki.

31. táblázat: Az 5. fejezet eredményeinek táblázata

\begin{tabular}{|c|c|c|c|c|}
\hline & Propozíció & $\begin{array}{l}\text { Támogatá } \\
\text { sra talált }\end{array}$ & $\begin{array}{l}\text { Részben } \\
\text { támogatá } \\
\text { sra talált }\end{array}$ & $\begin{array}{c}\text { Nem } \\
\text { talált } \\
\text { támogatá } \\
\text { sra }\end{array}$ \\
\hline 1 a p. & $\begin{array}{l}\text { Az állam eredetileg azért lépett be a } \\
\text { kockázati tőkepiacra, hogy kitöltse a } \\
\text { finanszírozási rést a korai fázisú } \\
\text { finanszírozási szegmensben, ahol a magán } \\
\text { kockázati tőkebefektetők inaktívak voltak. }\end{array}$ & $x$ & & \\
\hline $1 b \mathrm{p}$. & $\begin{array}{l}\text { A Jeremie program lefolyása során növelte } \\
\text { a kockázati tőkebefektetési tevékenységet } \\
\text { Magyarországon. }\end{array}$ & $x$ & & \\
\hline $1 c \mathrm{p}$. & $\begin{array}{l}\text { A Jeremie program sikeresen elérte } \\
\text { regionális fejlesztéssel kapcsolatos célját. }\end{array}$ & & & $x$ \\
\hline $1 d \mathrm{p}$. & $\begin{array}{l}\text { A Jeremie program sikeresen finanszírozta } \\
\text { a befektetést legjobban igénylő korai fázisú } \\
\text { cégeket. }\end{array}$ & & & $x$ \\
\hline $1 e \mathrm{p}$. & $\begin{array}{l}\text { A Jeremie program pozitív hatással volt a } \\
\text { céltársaságokra. }\end{array}$ & & $x$ & \\
\hline 1f $p$. & $\begin{array}{l}\text { A Jeremie program győztes alapkezelöinek } \\
\text { kiválasztása átlátható folyamat volt. }\end{array}$ & & & $x$ \\
\hline $\lg p$. & $\begin{array}{l}\text { A Jeremie program kivitelezése követte a } \\
\text { legjobb nemzetközi gyakorlatokat. }\end{array}$ & & & $x$ \\
\hline
\end{tabular}


2a p. A hazai állam a Jeremie program lefolyása során közvetlen módon is beavatkozott a kockázati tőkepiacon.

2b p. A hazai állam figyelme a közvetett beavatkozásról a közvetlen beavatkozásra terelődött a Jeremie programot követően.

2c p. A hazai közvetett állami beavatkozás stratégiai céljai közé tartozik a cégek finanszírozása pozitív externáliákat $\mathrm{X}$ biztosítva.

2d p. Az állam közvetett kockázati tőkés beavatkozást alkalmazott a COVID-19 pandémiára adott reakciója során.

Forrás: saját szerkesztés 


\section{Az állami tulajdonú kockázati tőkebefektetők befektetési preferenciái ${ }^{5}$}

A kockázati tőkebefektetők befektetési preferenciái számos kutató figyelmét felkeltették (Tyebjee \& Bruno, 1984; Macmillan et al., 1987; Robinson, 1987; Khan, 1987; Sandberg \& Hofer, 1987; Hall és Hofer, 1993; Zacharakis \& Meyer, 1995; Muzyka et al., 1996; Zacharakis \& Meyer, 1998; Shepherd, 1999; Mason \& Stark, 2004; Zacharakis \& Shepherd, 2005; Hsu et al., 2014). Ezt az érdeklödést Dorsey (1979), valamint Bruno és Tyebjee (1983) megállapításai váltották ki, amelyek azt mutatták, hogy a kockázati tőkebefektetők különösen jó érzékkel választják meg a befektetéseket. A kutatási terület fejlődése együtt járt a kockázati tőkebefektetési folyamat elemzésére vonatkozó módszertan fejlődésével. A megjelent tanulmányok a folyamat különböző szakaszaiban megjelenő befektetési preferenciákra összpontosítottak. A szakirodalom jelenleg kizárólag a privát kockázati tőkések befektetési preferenciáit mutatja be. Ez nem jelent problémát a nyugati gazdaságokban, ahol a korai fázisú befektetések többségét ezek a magánszereplők adják. A közép-kelet-európai régióban jelenleg azonban ezeket a befektetéseket elsősorban az állami szereplők hajtják végre (Karsai, 2018; Daszyńska-Żygadło et al., 2016).

A szakirodalomban található elméletek szerint az állami kockázati tőkebefektetőknek más preferenciáik lehetnek a befektetések kiválasztásakor, mint a privát kockázati tőkebefektetőknek. Pontosabban, az állami kockázati tőkebefektetők előnyben részesíthetik azokat a startupokat, amelyek szélesebb társadalmi hasznokat - például munkahelyteremtést vagy regionális fejlesztést -, és nem csupán pénzügyi megtérülést kínálnak (Colombo et al., 2016). Jelenleg a nemzetközi szakirodalomból hiányoznak olyan tanulmányok, amelyek megbízható, valós idejü módszerekkel vizsgálják a befektetési preferenciákat, és nem csupán a vizsgált szereplők beszámolóiból tájékozódnának. A közép-kelet-európai startuppereknek ismerniük kell az állami kockázati tőkebefektetők preferenciáit a finanszírozás megszerzéséhez, tekintve, hogy jelenleg túlnyomó mértékben állami tőkealap-kezelőktől lehet tőkefinanszírozáshoz jutni.

A szakirodalom csak a hagyományos privát kockázati tőkebefektetők preferenciáival foglalkozik, akik ismert piaci kudarcok, például információs

\footnotetext{
${ }^{5}$ Ezt a kutatást Jáki Erikával végeztem, a kutatás eredményei a Vezetéstudományban kerültek publikálásra (Molnár \& Jáki, 2020).
} 
aszimmetriák és tranzakciós költségek miatt nem fektetnek be ebben a korai szakaszban (Colombo et al., 2016; Lovas, 2015), tehát a kockázati tőkebefektetési preferenciák kutatása hiányzik ezekben a korai szakaszokban. Az angyalbefektetők preferenciáiról szóló szakirodalom alapján a startupperek nem tudnak felkészülni a kockázati tőkebefektetők befektetési preferenciáira a korai szakaszban, mivel az angyal- és a kockázati tőkebefektetők jellemzői között alapvető különbségek vannak, mint az eltérő szakmai háttér, a kialakítandó portfólió mérete és a kockázatkezelési szempontok (Hsu et al., 2014; Mason \& Stark, 2004). Ennek a kutatásnak a célja, hogy segítsen a startuppereknek jobban megérteni, mely tulajdonságokat keresik az állami kockázati tőkebefektetők az inkubációs, a magvető és a növekedési szakaszban történő befektetések során. Módszertani szempontból a verbális protokoll elemzés valós idejű kutatási módszerét alkalmaztuk.

A kutatás eredményei segítik a startupokat abban, hogy felmérjék, készen állnak-e állami kockázati tőkebefektetőkhöz fordulni a társaság jelenlegi életszakaszában. Emellett segítséget nyújt a döntéshozók számára abban is, hogy tapasztalatokon alapuló visszajelzéseket kapjanak az állami befektetések megvalósulásáról. A szakirodalom alapján a menedzsment csapat a legfontosabb szempont a korai fázisú vállalkozások befektetése esetén, mivel ekkor a (többnyire angyal) befektetők a döntéseiket elsősorban a menedzsment minőségére alapozzák (Hsu et al., 2014). Ha az állami kockázati tőkebefektetők a privát kockázati tőkebefektetők preferenciája szerint fektetnek be, akkor a magvető és növekedési szakaszban a legfontosabb jellemző a piac lesz, majd a pénzügyek (Zacharakis és Shepherd, 2005; Mason és Stark, 2004; Shepherd, 1999). A kutatás eredménye azonban eltérhet a fentiektől, mivel az állami és a privát kockázati tőkebefektetők eltérhetnek egymástól az ipari fókuszban, befektetési célban, és a befektetési kiválasztási folyamat szabályozásában.

\subsection{Szakirodalmi összefoglaló}

A kockázati tőkebefektetők befektetési preferenciáit a 80 -as évek elejétől különféle módszerek segítségével vizsgálták elsőként az Egyesült Államok vonatkozásában. A legkorábbi cikkek főként kérdőíveket és interjúkat használtak a kockázati tőkebefektetők befektetési preferenciáinak feltárására. Tyebjee és Bruno (1984) strukturált interjúk és kérdőívek segítségével azonosította a kockázati tőkebefektetési döntések mögött húzódó négy általános tényezőt. Ezek a következők: 
(1) a piac vonzereje, (2) termékdifferenciálás, (3) vezetői képességek, (4) környezeti veszélyekkel szembeni ellenállás. Kutatásuk megalapozta a jövőbeni tanulmányokat, mivel élen járt a főbb befolyásoló tényezők feltárásában. Macmillan és szerzőtársai (1987) célja az volt, hogy ezeket az eredményeket a kockázatitőke-befektetők nagyobb mintáján validálják, és megállapították, hogy a legfontosabb befektetési tényező konzisztensen a menedzsment képessége volt. Azzal folytatják, hogy „a lótól (termék), a lóversenytöl (piac) vagy az esélyektöl (pénzügyi kritériumok) függetlenül a zsoké (vállalkozó) az, aki alapvetöen meghatározza, hogy a kockázati tökebefektető egyáltalán tesz-e tétet" (Macmillan et al., 1987:10). Ezt az eredményt Robinson (1987) megerősíti, kijelentve, hogy a vezetőségnek teljesnek és üzletileg már tapasztaltnak kell lennie. Emellett hangsúlyozza a termeléshez vagy a szolgáltatás nyújtásához szükséges technikai készségek, a kulcsszereplők vállalkozói tapasztalatai és az adott piac követelményei közötti egyensúly fontosságát. Khan (1987) döntéshozatali modellt használt a kockázati tőkés döntéseknek a realizált hozamra gyakorolt hatásának becslésére. Megállapította, hogy azon túl, hogy innovatív módon képes új piacokra lépni, a vállalkozó kreativitása és leleményessége a legmeghatározóbb tényező a befektetés realizált nyereségében. Dávid és BecskyNagy (2016) kérdőívet készítettek a magyar kockázati tőkebefektetők befektetési preferenciáinak felmérésére, amely szerint azok a befektetési lehetőség minden jellemzőjénél fontosabbnak tartják a befektetés hozamgenerálási képességét.

A fenti tanulmányok mind kérdőíveket és interjúkat használtak adatgyüjtési módszerként. Sandberg és Hofer (1987) azonban nem javasolják a kérdőívek használatát a kockázati tőkebefektetési preferenciák tanulmányozásában, mert ezzel a módszerrel hamisan egyszerüsíthető a döntéshozatali folyamat. Azt javasolják a kutatóknak, hogy valós idejü módszereket, például megfigyelést és verbális protokollt használjanak adatgyüjtési technikákként e terület tanulmányozására. Később Zacharakis és Meyer (1998) kimutatták, hogy a korábbi munkákban alkalmazott módszerek - például kérdőívek és interjúk - nagy valószínűséggel elfogultak. Ennek az az oka, hogy az emberek (még a szakértők is) hajlamosak torzítva emlékezni tapasztalataikra és preferenciáikra (visszaemlékezési torzítás), vagy korábbi cselekedeteiket megpróbálják utólag igazolni (post-hoc racionalizálás). A szerzők szerint a kockázati tőkebefektetőknek nagyon nehéz belülről vizsgálniuk saját döntéshozatali folyamataikat. 
Így a verbális protokollok használata nyert teret kutatási módszerként a területen, amely a befektetés értékelése során a kockázati tőkebefektetők megfigyelésén alapuló valós idejű módszer. Hall és Hofer (1993) 16 verbális protokollt végzett el kockázati tőkebefektetőkkel, megfigyelve és rögzítve, hogyan értékelték a startupok befektetési javaslatait. Megállapították, hogy a kockázati tőkebefektetők csak addig olvassák el a dokumentumot, amíg azonnali elutasítást eredményező kritikus hibát nem fedeznek fel. Azt a következtetést is levonták, hogy az átvilágítási szakaszban a kockázati tőkebefektetők a javaslat minőségét és a befektető portfóliójába való illeszkedését („fit”) értékelték legnagyobbra. A második körös értékelés során azonban a kockázati tőkebefektetők a startupok partnereinek ajánlásait értékelték a legjobban. Zacharakis és Meyer (1995) is a verbális protokoll elemzés megközelítést alkalmazták, két kockázati tőkealap-kezelöt bevonva tanulmányukba. A kockázati tőkebefektetőknek részben saját korábbi, részben a kutatók által biztosított befektetési javaslatokat kellett értékelniük. A kutatók megállapították, hogy a kockázati tőkések legjobban a startup termékének vagy szolgáltatásának innovatív tulajdonságait értékelik, és arra a következtetésre jutottak, hogy ezeket a lehető legelőbb be kell mutatni az üzleti tervben. Mason és Stark (2004) nem kizárólag a kockázati tőkebefektetői preferenciákat tanulmányozta, hanem verbális protokoll elemzéssel hasonlította össze az üzleti angyalok, bankárok és kockázati tőkebefektetők befektetési preferenciáit. Megállapították, hogy a kockázati tőkebefektetők leginkább a piaci növekedési potenciált, a piaci keresletet, a belépési korlátok meglétét és a startup pénzügyeit értékelték (például a pénzügyi mutatókat, a vállalat értékét és az exittel járó várható megtérülést).

A menedzsment csapat minőségét különösebben nem találták fontosnak a kockázati tőkebefektetők számára, ami máris ellentmond a 80-as évekbeli kérdőív alapú tanulmányok megállapításainak. E fejezet a szerzők által alkalmazott preferenciaösszehasonlítási megközelítésre épít. A verbális protokoll elemzésnek más alkalmazásai is előfordultak a befektetési döntéshozatali folyamatok korai stádiumú angyalbefektetői szegmensben történő tanulmányozása során (Smith et al., 2010; Harrison et al., 2015; Mason és Botelho, 2016).

A verbális protokollelemzés mellett a kockázati tőkebefektetési döntés témájának kutatói egy másik kutatási módszert, nevezetesen a conjoint elemzést is kedvelték. E módszer keretein belül a kutatók előre meghatározott tulajdonságokat tekintve eltérő befektetési döntési párokat állítanak a kockázati tőkések elé, arra 
kérve öket, hogy válasszanak közülük. Az eredményeket statisztikailag elemzik, hogy megtalálják a befektetési döntések mögött álló fö tényezőket. Ez a módszer megoldást kínál a memóriatorzításra és a post-hoc racionalizálási problémákra is, de kevésbé gazdag információkat eredményeznek, mint a verbális protokoll elemzéssel. Muzyka és szerzőtársai (1996) európai kockázati tőkebefektetőktől gyüjtött adatok felhasználásával készítettek conjoint elemzést, akiknek 53 darab párokba rendezett befektetési lehetőség közül kellett választaniuk. Megállapították, hogy a kockázati tőkebefektetők szemében a vezetői képességek, tapasztalatok és értékesítési készségek, valamint a piaci részesedés fenntarthatósága a legkeresettebb tulajdonság. Shepherd (1999) az ausztrál kockázati tőkebefektetőktől összegyüjtött adatokon végzett conjoint elemzést, és a menedzsment csapat iparági tapasztalatát és képzettségét, valamint a versenytársak erejét találta a legfontosabb tényezőknek. Conjoint elemzésük során Zacharakis és Shepherd (2005) ugyanezen tényezőket találta erősnek a termékdifferenciálás és a piaci növekedési potenciál mellett. Végezetül conjoint elemzés alkalmazásával Hsu és szerzőtársai (2014) megállapították, hogy az angyalbefektetők nagyobb hangsúlyt fektetnek a stratégiai felkészültségre és az affektív szenvedélyre, mint a gazdasági potenciált előnyben részesítő kockázati tőkebefektetők.

\subsection{Kutatási célok}

A kutatásunkban az állami kockázati tőkebefektetők befektetési preferenciáit vizsgáltuk általánosságban és külön-külön az inkubációs, a magvető és a növekedési szakaszban történő befektetések során, a verbális protokoll elemzés valós idejü kutatási módszerével. Ez a kutatás a kockázati tőkebefektetési preferenciákról szóló jelenlegi szakirodalomhoz egészíti ki az alábbi kutatási kérdések megválaszolásával.

32. táblázat: Kutatási kérdések a 6. fejezethez

1. Milyen tulajdonságokat keresnek az állami kockázati tőkebefektetők összességében a céltársaságokban?

2. Milyen tulajdonságokat keresnek az állami kockázati tőkebefektetők az inkubációs fázisú társaságokban?

3. Milyen tulajdonságokat keresnek az állami kockázati tőkebefektetők a magvető fázisú társaságokban?

4. Milyen tulajdonságokat keresnek az állami kockázati tőkebefektetők a növekedési fázisú társaságokban?

5. Mennyire értékelik az állami kockázati tőkebefektetők az innovációt a céltársaságokban? 
Forrás: saját szerkesztés

A kutatás célja feltárni, hogy az állami kockázati tőkefinanszírozó mely tulajdonságokat értékeli általában. Az állami kockázati tőkebefektetők preferenciái várhatóan összességében hasonlóak a privát kockázati tőkebefektetők preferenciáihoz. A szakirodalom alapján arra számítunk, hogy az állami kockázati tőkebefektetők a piac jellemzőit értékelik a legjobban, majd a vállalkozások pénzügyeit (Zacharakis \& Shepherd, 2005; Mason \& Stark, 2004; Shepherd, 1999).

la propozíció: Az állami kockázati tökebefektetö összességében a piacot értékeli leginkább, ezt a célvállalkozás pénzügyei követik.

Emellett a magyar állam európai uniós források felhasználásával elindította a GINOP programot a 2014-2020-as programozási időszak részeként kifejezetten azzal a céllal, hogy fejlessze az ország innovációs képességeit (Palyazat.gov.hu, 2014). Számos alprogramban szerepelnek állami kockázati tőkealapokba történő befektetések, ez arra a feltételezésre vezet, hogy az állami kockázati tőkebefektetők összességében nagyra értékelik a céltársaság termékének vagy szolgáltatásának innovatív minőségét.

$1 b$ propozíció: Összességében az állami kockázati tőkebefektetők nagyra értékelik a termék/szolgáltatás kategórián belül az innovációs értékét.

Várhatóan a három befektetési szakasz eredményei is változnak. Az inkubációs szegmensben az állami kockázati tőkebefektetők preferenciáinak jó indikátorai lehetnek az angyalbefektetők által alkalmazott kritériumok, akik az életciklus legkorábbi stádiumában lévő vállalatokba fektetnek be. Az angyalbefektetőket befektetési döntésük során nagyban befolyásolják a vállalkozó személyes tulajdonságai, mivel az információs aszimmetriák problémája nagyon gyakori az inkubációs szakaszban (Hsu, 2014). A menedzsment csapat várhatóan a legfontosabb szempont lesz a befektetés korai szakaszaiban, hiszen a korábbi szakirodalom szerint a befektetés korai szakaszában a befektetők döntéseiket elsősorban a menedzsment minőségére alapozzák, mivel a cég történetéröl nagyon kevés információ áll rendelkezésre, így nehéz pénzügyi adatokra vagy elörejelzésekre támaszkodni (Hsu et al., 2014). Ezen kívül várhatóan a befektetők ebben a szakaszban nem fektetnek nagy hangsúlyt az üzleti terv minőségére, mivel még a vállalat terméke vagy szolgáltatása sincs véglegesítve, tehát az üzleti tervekre itt nem lehet alapozni. Ebből a következő propozíció vázolható fel: ha az állami kockázati tőkebefektető hasonló 
problémákkal találkozik az inkubációs szakaszban, mint az angyalbefektetők, akkor hasonló preferencia-struktúrát fog követni, tehát a legnagyobb jelentőséget a céltársaság vezetőségének tulajdonítja, az üzleti tervnek és a pénzügyi adatoknak kisebbet.

2a propozíció: Az inkubációs fázisban az állami kockázati tőkebefektetők leginkább a céltársaság menedzsmentjét értékelik.

$2 b$ propozíció: Az inkubációs fázisban a cég pénzügyi számai az állami kockázati tökebefektetök által legkevésbé értékelt tulajdonságok között szerepelnek.

2c propozíció: Az inkubációs fázisban az üzleti terv minösége az állami kockázati tökebefektetők által legkevésbé értékelt tulajdonságok között szerepel.

A hagyományos kockázati tőkebefektetők a befektetés magas tranzakciós költségei és a kis befektetések méretgazdaságosságának hiánya miatt nem fektetnek be inkubációs fázisú társaságokba, így inkább a fejlettebb, nagyobb befektetéseket igénylő startupokat részesítik előnyben.

Tehát a magvető és a növekedési szakaszban az állami kockázati tőkebefektetők várhatóan a privát kockázati tőkebefektetők preferenciája szerint fektetnek be, de némi különbséggel: míg a privát kockázati tőkebefektetők az üzleti terv minőségét nem értékelik igazán (Zacharakis \& Shepherd, 2005; Mason \& Stark, 2004; Shepherd, 1999), az állami kockázati tőkebefektetők várhatóan nagyra értékelik azt, mivel köztudott, hogy az állami kockázati tőkebefektetők nagyobb bürokráciának vannak kitéve (Karsai, 2017a), és ez megnyilvánulhat abban, hogy fokozott figyelmet fordítanak az üzleti terv szerkezetére, ami a további nyilvántartás alapja.

3 a propozíció: Magvetö fázisban az állami kockázati tőkebefektetők a piacot, majd a céltársaság pénzügyeit értékelik leginkább.

3 bropozíció: Magvetö fázisban az állami kockázati tőkebefektetők a három leginkább értékelt tulajdonság közé sorolják a céltársaság üzleti tervét.

4 a propozíció: Növekedési fázisban az állami kockázati tökebefektetők a piacot, majd a céltársaság pénzügyeit értékelik leginkább.

4 b propozíció: Növekedési fázisban az állami kockázati tökebefektetők a három leginkább értékelt tulajdonság közé sorolják a céltársaság üzleti tervét.

Az állami kockázati tőke és a privát kockázati tőkebefektetők befektetési preferenciák különbözhetnek, mivel eltérő az ipar fókusz, a befektetés célja és a befektetési kiválasztási folyamat szabályozása. Ennek a fejezetnek a következtetései 
segíteni fogják a startupokat felmérni, készen állnak-e állami kockázati tőkebefektetőkhöz fordulni jelenlegi életszakaszukban, emellett segítséget nyújt a döntéshozók számára abban is, hogy tapasztalatokon alapuló visszajelzéseket kapjanak az állami befektetések megvalósulásáról.

\subsection{Módszertan}

Először az adatgyüjtési módszer, majd az adatelemzés technikái kerülnek bemutatásra.

\subsubsection{Adatgyüjtés}

A 2018 tavaszán gyüjtött mintába kilenc magyar állami kockázati tőkés befektetési menedzsert kértünk fel interjúra. Három inkubációs fázisú startupokba végzett befektetést, további három magvető fázisú startupokba és három növekedési fázisú startupokba. Kiválasztásukat egy belső szakértő segítette (szakértői mintavétel), akit megkértünk, hogy javasoljon menedzsereket az egyes életciklusspecializációkból a demográfiai jellemzők legjobb reprezentációjának érdekében (Horváth \& Mitev, 2015). A véletlenszerü minta lett volna ideális, azonban tekintve a befektetések bizalmas természetét, véletlenszerü mintavételre nem volt lehetőségünk. A reputációs alapú mintavétel a második legjobb lehetőség az általánosíthatóság szempontjából. Ezek a befektetési menedzserek általában középkorú férfiak, akik üzleti vagy pénzügyi mesterdiplomával rendelkeztek. Mindegyikük jártas az üzleti tervek értékelésében és a vállalatértékelésben.

Az inkubációs fázisba befektető állami kockázati tőkebefektetők csak ötlettel rendelkező startupokat céloznak meg és szerény összegü befektetést biztosítanak. A magvető fázisban befektető állami kockázati tőkebefektetők olyan startupokat céloznak meg nagyobb befektetéssel, amelyek már megkezdték a prototípus fejlesztését és a piaci visszajelzések gyüjtését. A növekedési szakaszban befektető állami kockázati tőkebefektetők olyan már jól müködő startupokat céloznak meg jelentős mennyiségű befektetést biztosítva, amelyek már befejezték a prototípus fejlesztését és elegendő piaci visszajelzéssel rendelkeznek. A tanulmány egyik célja annak bemutatása, hogy az állami kockázati tőkebefektetői preferenciák hogyan különböznek az életciklus három különböző szakaszában az állami kockázati tőkebefektetőnél.

Minden verbális protokoll-interjú egyórás volt, amelyek során két verbális protokoll készült el, mely 18 verbális protokoll-átiratot eredményezett. Ez az 
adatgyüjtési módszer nagyon gazdag adatokat szolgáltatott, de kivételesen időigényes, ezért e vizsgálatok tipikus mintamérete kicsi. Összehasonlításképpen Hall és Hofer (1993) mintájának mérete 16 verbális protokoll-interjú volt, Zacharakis és Meyer (1995) 4 verbális protokoll-interjút, Mason és Stark (2004) 9 verbális interjút készítettek kockázati tőkésekkel. Egy felmérés szerint a problémamegoldó tanulmányok verbális protokolljainak tipikus mintamérete 1 és 20 között van (Chiu \& Shu, 2010), ami szintén megerösíti, hogy a fejezet mintanagysága a módszertan esetében jellemző nagyságok között a nagyobbak közé sorolható. Tekintettel arra, hogy az állami kockázati tőkebefektetők adatait - főleg, ha valós időben rögzített adatról van szó - nehéz megszerezni, így ebből a kutatásból még a korlátozott minta mellett is fontos tényeket lehet megtudni az állami kockázati tőkebefektetőkről.

A verbális protokollelemzés valós idejü megfigyelésböl áll, amelynek során a kutatók rögzítik az alany gondolkodásmódját és döntéshozatalát. A megfigyelés és a rögzítés szakaszában a befektetési menedzserek elolvastak egy startup vállalkozók által küldött üzleti tervet, miközben megfogalmazták kritikai gondolataikat és benyomásaikat. A verbális protokoll végrehajtásának eljárása a következő (Ericsson \& Simon, 1993), melyeket az eljárás során pontosan követtünk:

1) A kísérlet megkezdése előtt egyértelművé kell tenni az alanyok számára, hogy a kísérlet során folyamatosan hangosan meg kell fogalmazniuk gondolataikat, beleértve bármit, ami eszükbe jut. Ha az alanyok 30 másodpercnél tovább hallgatnak, a kutatónak emlékeztetnie kell őket arra, hogy folytassák gondolataik hangos kinyilvánítását.

2) A kísérlet megkezdése előtt tanácsos elvégezni egy próbaüzemet, pl. megoldani egy egyszerü matematikai feladatot. A kutató megkérheti az alanyt egy egyszerü összeadás végrehajtására fejben, de annak minden felmerülő gondolatot hangosan ki kell kimondania a feladat végrehajtása közben. Így az alany némi gyakorlatot szerezhet a kísérlet megkezdése elött.

3) A verbális protokoll kísérlet elvégzése, az elhangzottak rögzítése felvételen.

4) A felvételek átiratának elkészítése az elemzés megkezdéséhez.

Különös figyelmet kell fordítani arra, hogy milyen üzleti terveket értékelnek a befektetési menedzserek. Problémákat vet fel, ha minden résztvevőnek ugyanazt az üzleti tervet adjuk. Például, ha egy befektetési menedzser olyan startup üzleti tervét olvassa el, amely nem felel meg az iparági és az életciklus-specializációjának, a 
befektetési javaslatot azonnal elutasítja. További probléma, hogy a kutatók által benyújtott üzleti tervek csökkentik a kutatás gyakorlati érvényességét. Ha azonban a kockázati tőkebefektetőket arra kérik, hogy saját maguk által kapott üzleti terveket olvassanak el és értékeljenek, akkor ezek a problémák nem merülnek fel, és a tanulmány érvényessége jelentősen megnő (Zacharakis \& Meyer, 1995). Nyilvánvaló, hogy a befektetőknek ugyanazon üzleti tervek benyújtása növelte volna az eredmények összehasonlíthatóságát, ugyanakkor a ténylegesen kapott, valós üzleti tervek értékelésének előnyei Zacharakis és Meyer (1995) szerint messze felülmúlják ezt az árat. A verbális protokoll elemzés kiváló a döntési helyzetek vizsgálatához, feltéve, hogy a következő kritériumok teljesülnek (Ericsson \& Simon, 1993). Ebben a tanulmányban mindezek a kritériumok teljesültek, lásd az alábbi táblázatot.

33. táblázat: A verbális protokoll elemzés végrehajtásának kritériumai

\begin{tabular}{ll}
\hline Kritériumok & Megvalósítás ebben a kutatásban \\
\hline $\begin{array}{l}\text { A közölt információnak a } \\
\text { figyelem fókuszában kell } \\
\text { lennie }\end{array}$ & $\begin{array}{l}\text { Minden interjú zavartalan, csendes, zárt irodateremben } \\
\text { készült, ahol csak az interjú alanyai és a kutatók voltak jelen }\end{array}$ \\
$\begin{array}{l}\text { Az alanyok figyelmét } \\
\text { semmi nem tereli el }\end{array}$ & \\
\hline
\end{tabular}

A feladatot a megszokás nem teszi nagy mértékben Különféle iparágak valós üzleti tervei voltak felhasználva rutinná

Csak rövid időnek szabad Az alanyok folyamatosan hangosan fogalmazták meg eltelnie az végrehajtás és a gondolataikat az üzleti terv értékelése során, az alanyokat verbalizáció között 30 másodperc hallgatás után emlékeztették arra, hogy folytassák a gondolataik hangos kimondását.

A verbalizáció nem igényel Az alanyok úgy fogalmazták meg saját gondolataikat, ahogy túlzott kódolást azok eszükbe jutottak

A beszámolók szóban történnek

Az interjúk személyes jelenléttel készültek

Az instrukciók tiszták

Minden interjú elején egyértelmủ magyarázatok hangzottak el a vizsgálat módjáról és céljáról

Javasolt a beszámolók teljessége

Minden üzleti terv értékelése teljes, befejezett volt

(Forrás: saját szerkesztés)

\subsubsection{Adatelemzési eljárás}

Először elkészült a verbális protokoll felvételek átirata. Az átírt szövegben úgynevezett „gondolatszegmensek” kerültek azonosításra, amelyek lehettek szavak, 
mondatrészek vagy teljes mondatok, amelyek összefüggő és elhatárolható gondolati egységet képviseltek. A mérhető eredmények eléréséhez az egyes gondolatszegmenseket egy-egy olyan kvalitatív tulajdonságba vagy kategóriába kell kódolni, amelynek fontosságát a befektetési döntésekben mérni szeretnénk. A korábbi tanulmányokat követve (Hall \& Hofer, 1993; Mason \& Stark, 2004; Robinson, 1987; Zacharakis \& Meyer, 1995, 1998) ebben a kutatásban az általuk meghatározott kategóriákat használtuk a kutatási kérdések megválaszolásához (lásd az alábbi táblázatot).

34. táblázat: A kategóriákként használt minőségi tulajdonságok

\begin{tabular}{ll}
\hline Menedzsment csapat & a menedzsment csapat korábbi vállalkozói tapasztalata \\
& a menedzsment csapat képzettsége \\
& alapvető (,,core”) képességek megléte \\
Termék/Szolgáltatás & a termék vagy szolgáltatás innovációs értéke \\
& a termék vagy szolgáltatás készültségének szintje \\
& a termék vagy szolgáltatás kinézete \\
& növekedési potenciál, skálázhatóság \\
& a piac telítettsége, növekedési korlátok \\
Piac & az üzleti terv mélysége \\
& az üzleti terv szakmaiságának szintje \\
Üzleti terv & pénzügyi terv (bevétel- és költségszerkezet, tőkeberuházások, \\
pénzáramlások) & vállalat értéke \\
& exit-lehetőségek \\
\end{tabular}

(Forrás: saját szerkesztés)

A pénzügyek kategóriája főként az üzleti terv tervezett bevételi és költségszerkezetből, tőkeberuházásokból és pénzáramlásokból álló pénzügyi terv részével kapcsolatos megjegyzéseket tartalmazza. Ez a pénzügyi terv elvárt mindhárom életszakaszban. Emellett tartalmazza a befektetési menedzser várakozásait az exit-lehetőségekről (azaz: ki vásárolhatja fel ezt a vállalatot?), illetve a vállalat valószínűsíthető értékéről (fejszámolás alapján, ezekben a pénzügyi tervekben nem szükséges a vállalatértékelés). Az elemzésben deduktív kódolást alkalmaztunk, ami azt jelenti, hogy a kategóriákként használt tulajdonságok köre növelhető olyan gondolatszegmensek felfedezésekor, amelyek nem illenek az elöre meghatározott kategóriákba (Cho \& Lee, 2014). 
Ezt követően elkészültek az eredmények gyakorisági táblázatai az állami kockázati tőkebefektetők mind a három típusához (inkubációs, magvető és növekedési), hogy láthatóvá váljanak a startupok üzleti terveinek legfontosabb jellemzői közötti különbségek az egyes életciklusokban. A gyakorisági táblázatok használata a verbális protokoll elemzés során bevett gyakorlat a befektetési preferenciákat vizsgálatára (Hall \& Hofer, 1993; Mason \& Stark, 2004; Smith et al., 2010). Mint minden más kutatási módszernek, a verbális protokoll elemzésnek is vannak korlátai. Ide tartozik annak a lehetősége, hogy a gondolati egységek gyakorisága nem reprezentálja tökéletesen a preferencia-kritériumok fontosságát, hiszen lehetséges, hogy egy résztvevő többször is megemlít egy adott pontot, mert nem biztos benne, miközben csak egyszer említ egy másik pontot, amelyben teljesen biztos. Ezen kívül, bár valós idejü adatgyüjtési módszerről van szó, a verbális protokoll interjúk - tekintve, hogy az alany egy kísérletben vesz részt - torzíthatja az alany viselkedését is (Mason \& Stark, 2004).

\subsection{Eredmények}

Mindegyik állami kockázati tőkebefektető-típus (inkubációs, magvető és növekedési) hat különböző startup üzleti tervét értékelte, és gondolatszegmenseik öt kategóriához kapcsolódtak: pénzügyek, piac, termék/szolgáltatás, vezetőség és üzleti terv. Az alábbi táblázatban láthatjuk az egyes kategóriákban a gondolatszegmensek gyakoriságát összességében, illetve az egyes életszakaszokban.

35. táblázat: A befektetési preferenciák gyakorisági táblázata verbális protokoll elemzés alapján

\begin{tabular}{lcccc}
\hline Kategória & \multicolumn{4}{c}{ Gyakoriság (\%) } \\
\hline \multirow{2}{*}{ Pénzügyek egyes életszakaszokban és összesen } \\
Piac & Inkubációs & Magvető & Növekedési & Összesen \\
Termék/szolgáltatás & $25,4 \%$ & $31,8 \%$ & $27,5 \%$ & $\mathbf{2 8 , 4 \%}$ \\
Menedzsment csapat & $21,9 \%$ & $25,8 \%$ & $21,4 \%$ & $\mathbf{2 3 , 3 \%}$ \\
Üzleti terv & $21,9 \%$ & $23,7 \%$ & $21,4 \%$ & $\mathbf{2 2 , 5 \%}$ \\
\hline
\end{tabular}

(Forrás: saját adatbázis) 
16. ábra: A befektetési preferenciák hierarchiája összesítve a verbális protokoll elemzés alapján

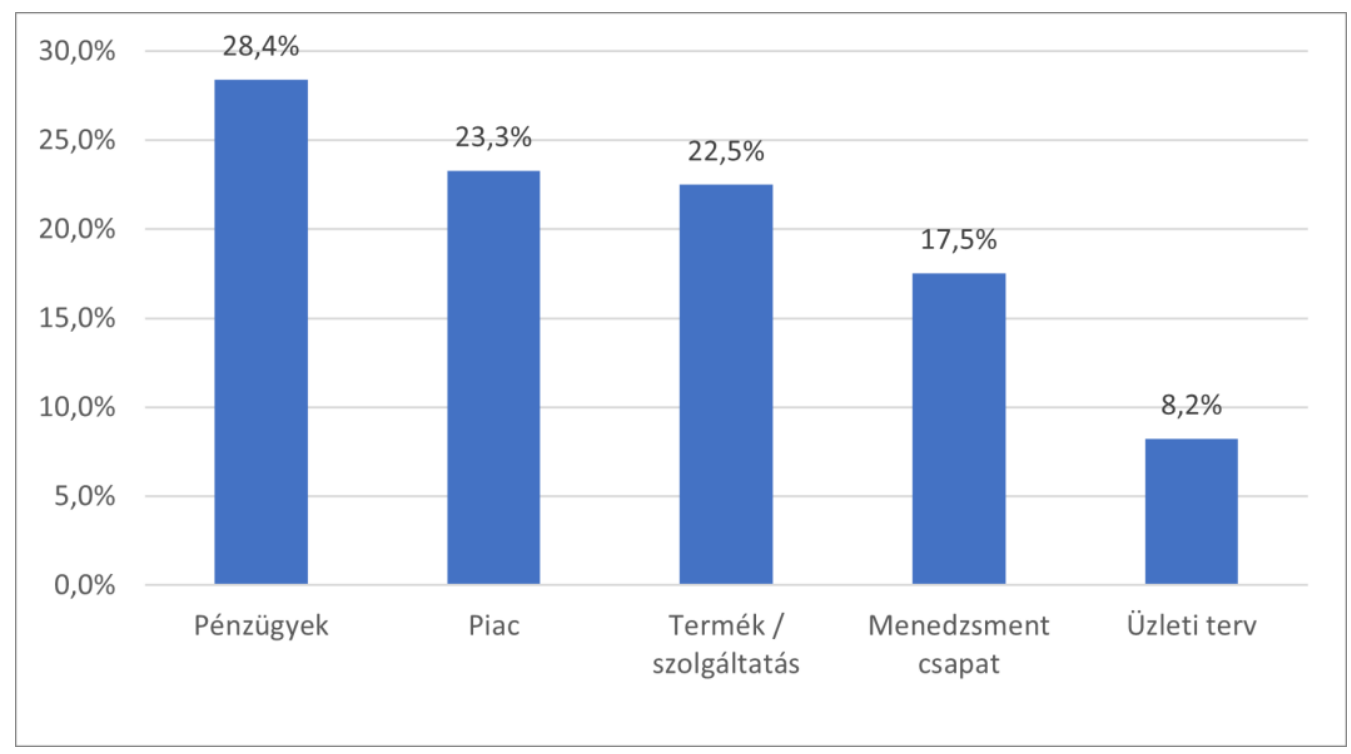

(Forrás: saját adatbázis)

Az összesített eredményeket (1. kérdés) megtekintve azt látjuk, hogy az állami kockázati tőkebefektetők a vállalat pénzügyeit értékelték a leginkább $(28,4 \%)$, majd a piac $(23,3 \%)$ következett. Mindez pontosan az ellentéte a privát kockázati tőkebefektetők preferenciáinak, akik általában a piacot értékelik a legjobban, majd a pénzügyeket (Zacharakis \& Shepherd, 2005; Mason \& Stark, 2004; Shepherd, 1999). Ez az eredmény nem támogatja az la propozíciót - „Az állami kockázati tökebefektetök összességében a piacot értékelik legelöbbre valónak, és ezt követik a céltársaság pénzügyei”. Ennek oka a nagyon szigorú állami felügyelet lehet, amely alatt az állami kockázati tőkebefektetők müködnek, és amely megköveteli tőlük, hogy a céltársaságok kiválasztásakor szorosan kövessék a pénzügyi irányelveket. A piac és a termék/szolgáltatás szinte egyformán fontos az értékelési folyamatban. A termék/szolgáltatás magas helyezése azért érdekes, mert a szakirodalomban vannak bizonyítékok arra, hogy a kockázati tőkések ezt nem értékelik fontosnak - például Mason és Stark (2004) szerint ez az egyik legkevésbé értékelt jellemző. Ennek oka az 5. kutatási kérdéshez és az $1 \mathrm{~b}$ propozícióhoz kötődik, amely kimondja, hogy "összességében az állami kockázati tökebefektetők nagyra értékelik a termék/szolgáltatás kategórián belül az innovációs értéket”. Kiderült, hogy a termék innovációs értékével kapcsolatos megfigyelések száma a termékkel kapcsolatos összes megfigyelés nagy részét tette ki, amint az a következő ábrán látható. 
17. ábra: Az innovációhoz kötődő megfigyelések aránya a termék/szolgáltatás kategóriában a verbális protokoll elemzés alapján

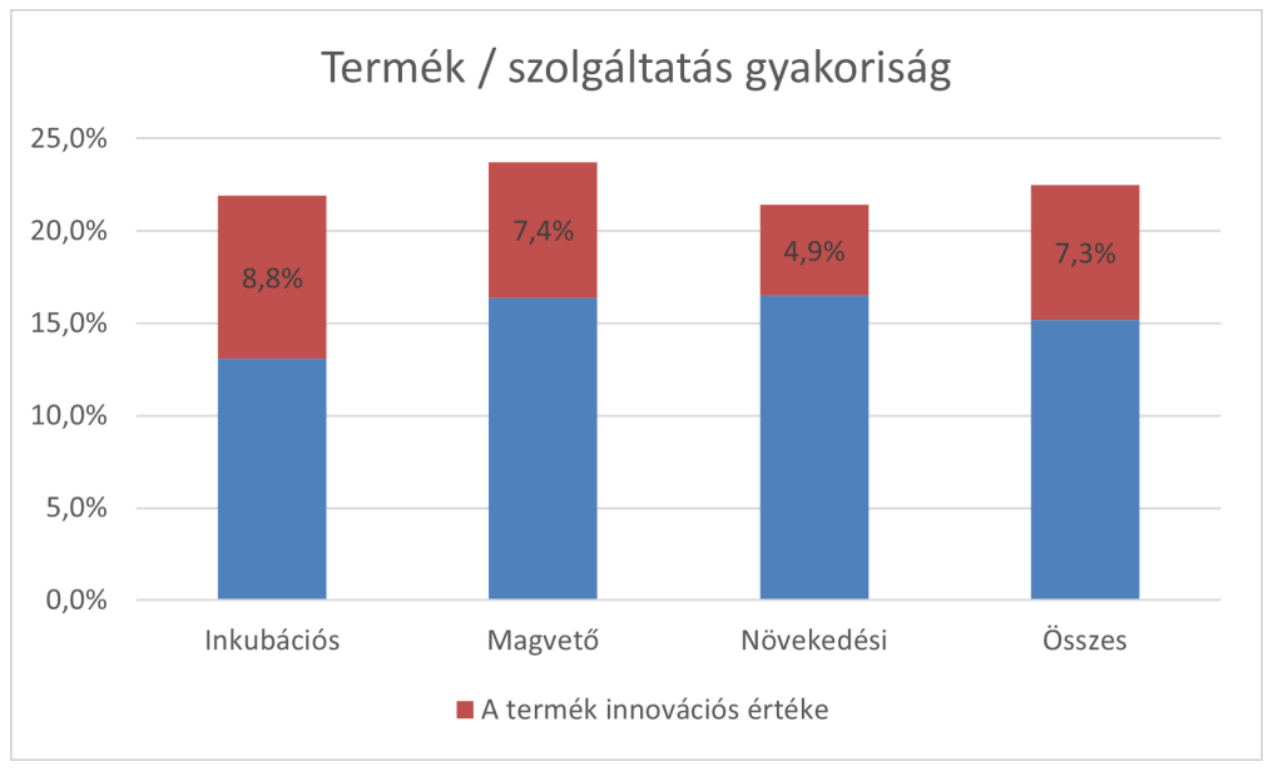

(Forrás: saját adatbázis)

Figyelemre méltó az is, hogy az állami kockázati tőkések a termék innovációs értékéről a termékkel kapcsolatos összes megfigyeléshez képest a legtöbbet az inkubációs szakaszban beszélnek (40\%-os részarány), a későbbi fázisokban kevesebbet (magvető: 31\%-os részarány, növekedési: 23\%-os részarány). Ez azzal magyarázható, hogy a legkorábbi fázisokban kisebb piaci validáció áll rendelkezésre a vállalatról, ami nagyobb felelösséget ró a kockázati tőkésre, hogy eldöntse, van-e innováció a termékben vagy sem. Egy növekedési fázisú vállalatnál az innovációt már tesztelte a piac, így kevésbé kell elemezni. Összességében ez támogatja az $1 \mathrm{~b}$ propozíciót. Kombinálva azt a két megállapítást, hogy (1) az állami kockázati tőkebefektető nagy hangsúlyt fektet a termék/szolgáltatás minőségére, és (2) a termék/szolgáltatás kategórián belül az innovációs érték elemzése nagy arányt tesz ki, ahhoz a megállapításhoz jutunk, hogy az állami kockázati tőkebefektető nagyra értékeli a termék innovatív értékét.

Az összesített rangsorban az üzleti terv minősége (8,2\%) éri el a legkisebb fontosságot. Így az állami befektetéseket kereső startuppereknek tisztában kell lenniük azzal, hogy cégüknek nagyon jó pénzügyi kilátásokkal kell rendelkeznie a finanszírozás elnyeréséhez. A következő részekben a három befektetési szakasz eredményeit és eltéréseit elemezzük. 


\subsubsection{Inkubációs}

Ebben a részben bemutatásra kerül, hogy melyek azok a tulajdonságok, amelyeket az állami kockázati tőkebefektetők az inkubációs fázisú vállalkozásokban keresnek (2. kutatási kérdés). Meglepő módon az állami kockázati tőkebefektetők a legtöbbet a társaság pénzügyi jellemzőinek kritériumáról beszéltek $(25,4 \%)$, amelyet szorosan követett a menedzsment csapat (23,7\%). Azonban a többi életszakaszhoz képest a menedzsment bizonyult a legtöbbet tárgyalt tényezőnek az inkubációs állami kockázati tőkebefektetőknél (magvető: 13\%, növekedés: 15,4\%).

18. ábra: A befektetési preferenciák hierarchiája az inkubációs szakaszban és összesítve a verbális protokoll elemzés alapján

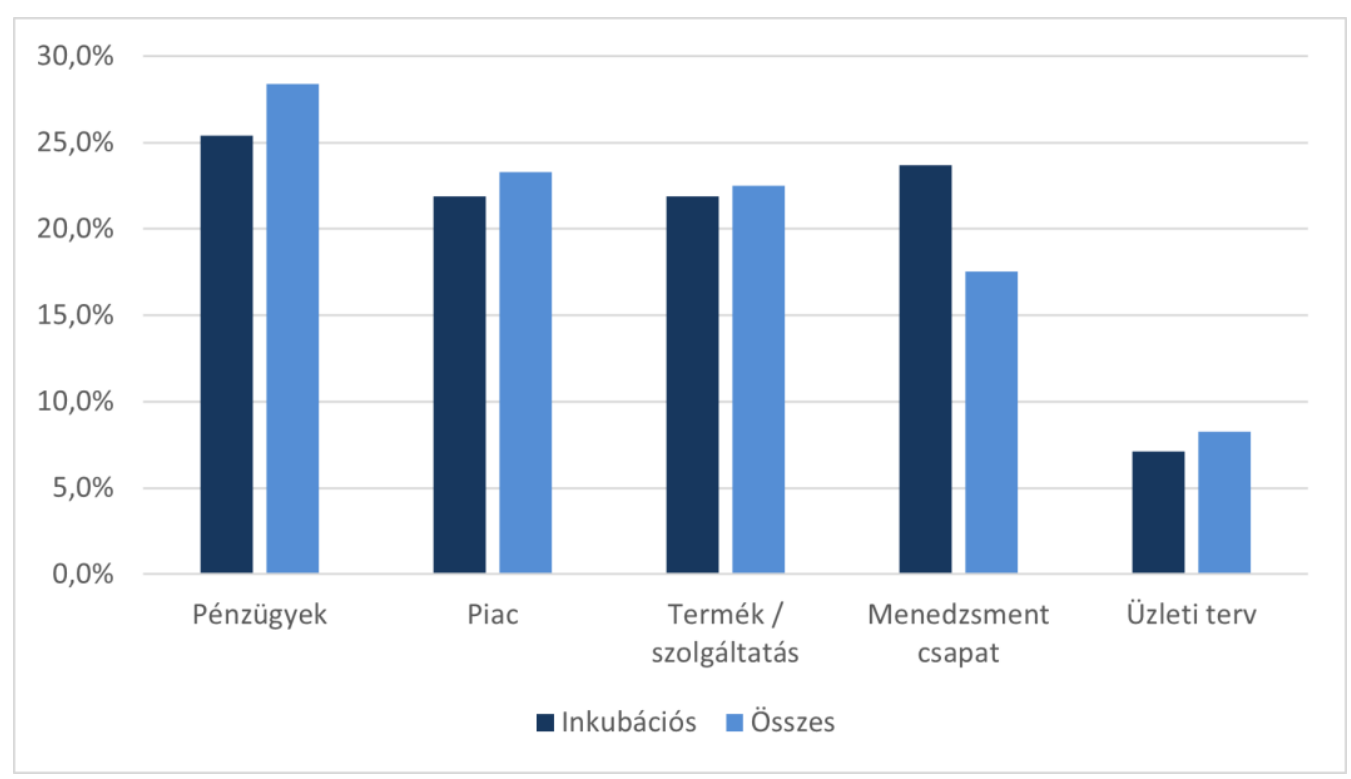

(Forrás: saját adatbázis)

A $2 a$ propozíció - „Az inkubációs szakaszban az állami kockázati tökebefektetök az angyalbefektetökhöz hasonlóan a menedzsment csapat tulajdonságait értékelik a leginkább" - részben támogatásra talált, mivel a menedzsment volt a legjobban értékelt jellemző a többi befektetési fázishoz képest, de az inkubációs szakaszban abszolút értelemben nem ezt értékelték a legmagasabbra. A kulcsszereplők tervezett részesedésének kérdése ebben az életszakaszban is releváns téma. A pénzügyek jelentősége azt sugallja, hogy az állami kockázati tőkések még a legkorábbi szakaszban is nagy hangsúlyt fektetnek egy startup jövedelmezőségére és megtérülési potenciáljára. Ezen a kategórián belül az állami kockázati tőkebefektetők különös figyelmet fordítottak a tervezett tulajdoni 
részesedések megoszlására. Az állami kockázati tőkebefektetők egyforma hangsúlyt fektettek a piacra és a termékkel kapcsolatos szempontokra (mindkettő értéke 21,9\%). Ezek még mindig viszonylag nagy súlyúak, és számos üzleti tervet kritizáltak a körültekintő piaci elemzések hiánya miatt, különös tekintettel a versenytársak azonosítására. Bizonyos esetekben még a piaci visszajelzések begyüjtése is pozitívumként hatott. A terméket illetően az állami kockázati tőkebefektetők az innovációs értékre koncentrálnak a legjobban, „olyasmit keresnek, amit még nem csináltak meg egymilliószor”. Czyżewska és szerzőtársai (2016) megmutatták, hogy az innováció a vállalkozói növekedés kulcsfontosságú mozgatórugója. Arra találtunk bizonyítékot, hogy az inkubációs fázisú állami kockázati tőkebefektetések menedzserei egészen más preferencia-struktúra szerint müködnek, mint a privát kockázati tőkebefektetők. A vállalat pénzügyeinek szempontja a legfontosabb minőség egy jelentkező startup esetében, ezt szorosan követi a menedzsment csapat. A menedzsment csapat jelentősége ebben a szakaszban az angyalbefektetők befektetési preferenciájához hasonlít (Hsu et al., 2014; Mason \& Stark, 2004), ami nagy valószínüséggel annak köszönhető, hogy az inkubációs szakaszban (ahol az angyalbefektetők is aktívak) a befektetőknek a menedzsment vélt képességeire kell alapozniuk döntésüket. A csapat azért kiemelt fontosságú, mivel ebben a nagyon korai szakaszban rendkívül kevés ellenőrizhető információ áll rendelkezésre a projektről, ami információs aszimmetriához vezet. Ez még meglepőbbé teszi azt, hogy az állami kockázati tőkebefektetők mekkora jelentőséget tulajdonítanak a vállalat pénzügyeinek már az inkubációs fázisban is, így a $2 b$ propozíció - „Az inkubációs fázisban a cég pénzügyei az állami kockázati tőkebefektetök által legkevésbé értékelt tulajdonságok között szerepelnek” - nem talált támogatásra. Ez megerősíti a korábbi magyarázatot, miszerint mivel az állami kockázati tőkebefektetők az állam forrásait költik, az elszámoltathatóságuk fokozott mértékü, és befektetési döntéseiket az üzleti tervek becsült pénzügyi elemei támasztják alá. Ez a megállapítás az életciklus mindhárom szakaszán keresztül fennáll. Az üzleti terv struktúrájához és lépéseihez kapcsolódó tulajdonságok csak minimális vizsgálat alatt voltak az inkubációs kategóriában $(7,1 \%)$, így a $2 c$ propozíció - „Az inkubációs fázisban az üzleti terv az állami kockázati tőkebefektetök által legkevésbé értékelt tulajdonságok között szerepel” - erös támogatásra talált. Ez érthető, hiszen ebben a korai stádiumban sokkal rövidebb az elvárt terv, mint a későbbi szakaszokban. 


\subsubsection{Magvetö}

Vizsgálatunk tárgya ezen részben, hogy az állami kockázati tőkebefektetők milyen tulajdonságokat keresnek a magvető fázisú vállalkozásokban (3. kérdés). A legtöbbet vizsgált tényező ismét egyértelműen a pénzügyek kategóriája $(31,8 \%)$. A pénzügyi terv, különösen az ár és a költségszerkezet a legtöbb kritika tárgya.

19. ábra: A befektetési preferenciák hierarchiája magvető szakaszban és összesítve a verbális protokoll elemzés alapján

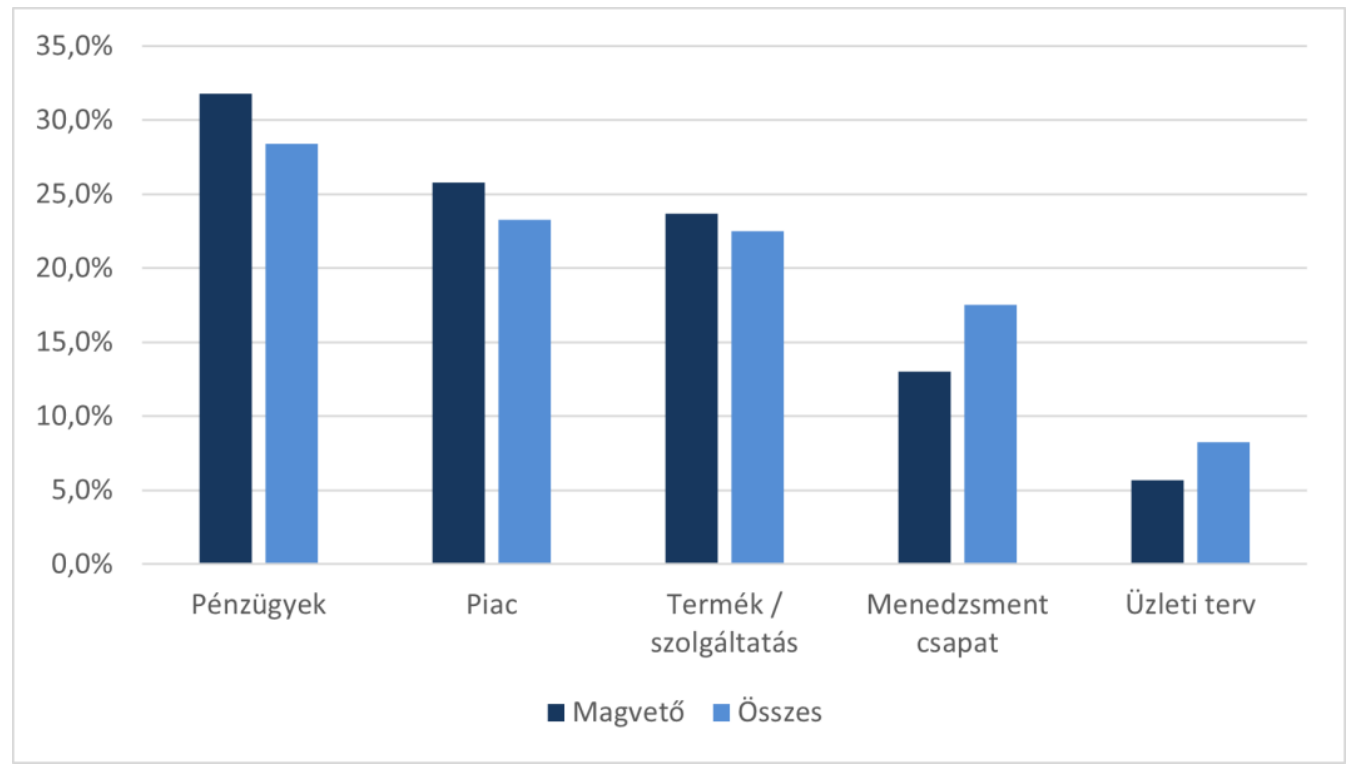

(Forrás: saját adatbázis)

Mivel a magvető stádium pénzügyi kritériumai jobban értékelhetőek, mint az inkubációs szakaszban (azonban a múltbeli adatok jelentős hiánya miatt az előrejelzés még mindig nagyon nehéz), érthető, hogy a közeljövőre vonatkozó részletes pénzügyi terv fontosabb kritérium. A magvető fázisú befektetések két másik fö tényezője a piac $(25,8 \%)$ és a termék $(23,7 \%)$, míg a menedzsment csapat $(13 \%)$ és az üzleti terv $(5,9 \%)$ a sor végén található. Igazán érdekes volt látni, hogy a menedzsment csapat ilyen alacsony jelentőségü a magvető szakaszban, ez hasonlít a korábbi verbális protokoll-vizsgálatok (Hall \& Hofer, 1993; Zacharakis és Meyer, 1995; Mason és Stark, 2004) állami kockázati tőkebefektetői preferenciáinak mutatóira, és ahogyan ök is sugallják, szöges ellentétben áll a korábbi post-hoc vizsgálatokkal (Tyebjee \& Bruno, 1984; Macmillan et al., 1987; Robinson, 1987; Khan 1987). Azonban a 3 a propozíció - „Magvető fázisban az állami kockázati tőkebefektetők a piacot, második helyen a céltársaság pénzügyeit értékelik 
leginkább" - nem találhat támogatásra. Ez a propozíció azzal a feltételezéssel alakult ki, hogy az állami kockázati tőkebefektetők a magvető és a növekedési szakaszban követik a privát kockázati tőkések befektetési preferencia-struktúráját, de nagyobb hangsúlyt fektetnek az üzleti tervre, mint a privát kockázati tőkebefektetők. Az eredmények azt mutatják, hogy az állami kockázati tőkebefektetők ehhez képest fordítva értékelik a pénzügyeket és a piacot (a pénzügyeket a legjobban, ezt a piac követi), ami még inkább megerősíti, hogy az állami kockázati tőkebefektetők nagy figyelmet fordítanak a társaság pénzügyeire, tehát az állami elöírások betartása érdekében szükséges a pénzügyi értékelési folyamat szigorú követése a céltársaságok kiválasztásakor. Az üzleti terv minősége volt a legkevésbé értékelt jellemző $(5,9 \%)$, tehát a $3 b$ propozíció - „Magvető fázisban az állami kockázati tőkebefektetők a három leginkább értékelt tulajdonság közé sorolják a céltársaság üzleti tervét” nem talált támogatásra. Ez lényegében azt jelenti, hogy az állami kockázati tőkések nagyobb hangsúlyt helyezhetnek az üzleti szempontból fontos tényezőkre, és nem kell túl sokat vizsgálniuk az üzleti terv felépítését, ami erős összhangban áll azzal, ahogy a privát kockázati tőkések értékelik ezt a jellemzőt. Ebből arra lehet következtetni, hogy az állami kockázati tőkebefektetők államilag ellenőrzött jellege az üzleti terv pénzügyi kilátásaira, és nem szerkezetére és általános minőségére való összpontosításban nyilvánul meg. Ez egy másik olyan megállapítás, amelyet jó, ha a startupperek szem előtt tartanak, amikor állami kockázati tőkefinanszírozásra pályáznak.

\subsubsection{Növekedés}

Mindezek után tekintsük meg azokat a tulajdonságokat, amelyeket állami kockázati tőkebefektetők a növekedési szakaszban keresnek (4. kérdés). A növekedési szakasz értékeléseinek eredményei hasonlítanak a magvetőéhez abban az értelemben, hogy a vállalat pénzügyeinek kategóriája a legfontosabb $(27,5 \%)$, ezt a piac követi (21,4\%), ám ebben a kategóriában a termék vagy szolgáltatás ugyanolyan fontos, mint a piac $(21,4 \%)$. 
20. ábra: A befektetési preferenciák hierarchiája növekedési szakaszban és összesítve a verbális protokoll elemzés alapján

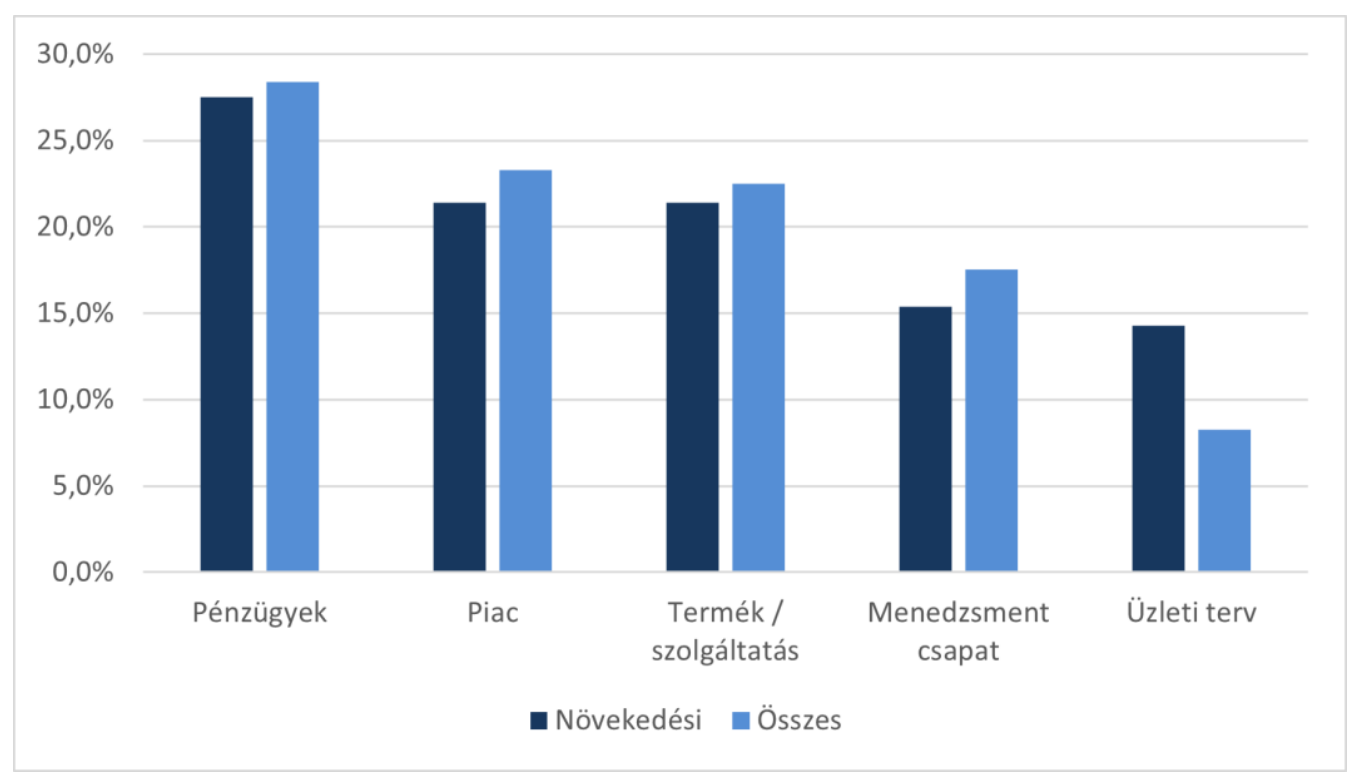

(Forrás: saját adatbázis)

A korábbiakhoz hasonlóan elmondható, hogy az eredmény nem támogatja a $4 a$ propozíciót - „Növekedési fázisban az állami kockázati tökebefektetők a piacot, majd a céltársaság pénzügyeit értékelik leginkább”. Az üzleti terv felépítésének (14,3\%) azonban ebben a szakaszban sokkal nagyobb jelentősége van a többi fázishoz képest, ami annak tulajdonítható, hogy az üzleti tervek ebben az életszakaszban a leghosszabbak, így több lehetőség van struktúrájuk és gördülékenységük kritizálására. Ennek ellenére a $4 b$ propozíció - „Növekedési fázisban az állami kockázati tőkebefektetők a három leginkább értékelt tulajdonság közé sorolják a céltársaság üzleti tervét” - még így sem támogatott, mivel az üzleti terv nem tartozik az első három leginkább értékelt jellemző közé). Így az állami kockázati tőkefinanszírozásra pályázó vállalkozóknak a korábbi szakaszokhoz képest több erőforrást kell fordítaniuk az üzleti terv szakszerü elkészítésére, de továbbra is számíthatnak arra, hogy viszonylag kevés kritikát fognak kapni az üzleti terv minőségével kapcsolatban. A következő táblázat a propozíciókkal kapcsolatos eredményeket tartalmazza.

36. táblázat: A 6. fejezet eredményeinek táblázata

\begin{tabular}{cccc}
\hline Propozíció & $\begin{array}{c}\text { Támogatásra } \\
\text { talált }\end{array}$ & $\begin{array}{c}\text { Részben } \\
\text { támogatásra } \\
\text { talált }\end{array}$ & $\begin{array}{c}\text { Nem talált } \\
\text { támogatásra }\end{array}$ \\
\hline
\end{tabular}




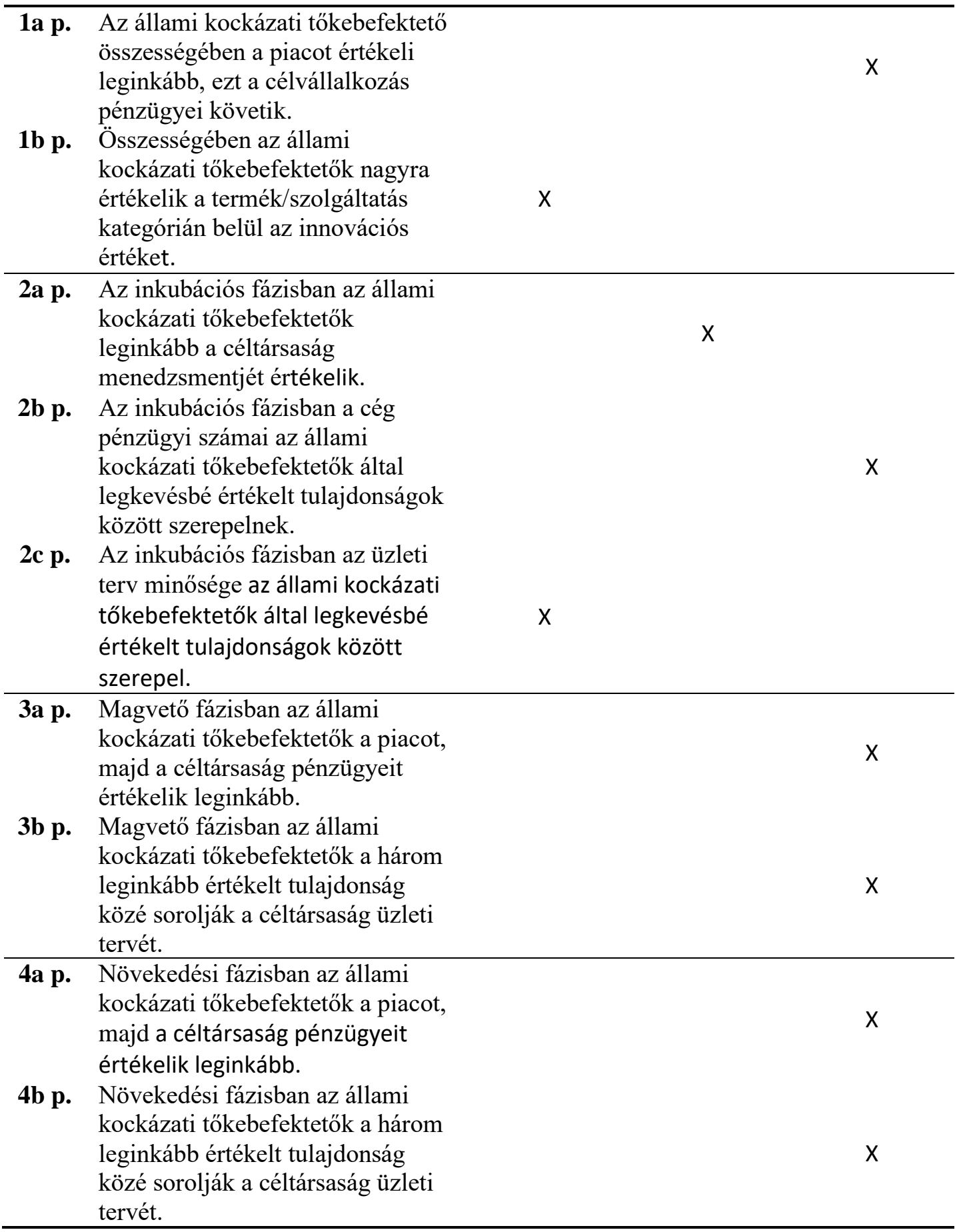

(Forrás: saját adatbázis)

\section{5 Állami kockázati tőkések befektetési preferenciáinak összegzése}

Az öt vizsgált kategória megfigyelései mentén összegezük, hogy a kockázati tőkefinanszírozást kereső startupoknak mit kell szem előtt tartaniuk.

A termék/szolgáltatási kategóriával kezdve a befektetési menedzserek gyakran kijelentették, hogy a termékleírás előtt a vállalkozónak meg kell mutatnia az általános piaci problémát, és meg kell magyaráznia, hogy termékük vagy 
szolgáltatásuk hogyan tudja megoldani ezt a problémát. E nélkül a startupperek azt kockáztatják, hogy úgy tünjön, nem ismerik az alapvető igényt a termékükre. Emellett a befektetési menedzserek kritizálják azt a vállalkozói hozzáállás, amikor a vállalkozók megpróbálják terméküket vagy szolgáltatásukat tökéletesnek, hibátlannak mutatni. A verbális protokollok szerint ez „,örös zászló” a befektetési menedzserek szemében, és gyanúsnak találják. A termékeknek mindig vannak hiányosságaik, és a startupoknak ezeket is meg kell mutatniuk, hogy alaposnak és hihetőnek tünjenek. Végezetül, a termék/szolgáltatás innovációs értékét is sokszor megkérdőjelezték a verbális protokollok során, például így: „nem volt benne semmi egyedi. Érezték, hogy van pénz az iparágban, de nem sikerült azonosítaniuk, hogy vessék meg a lábukat az ágazatban innovációt használva”.

A piaccal kapcsolatos megfigyeléseket illetően a befektetési menedzserek által legkeresettebb elem a startupok azon képessége volt, hogy megmutassák, van kereslet a piacon a megoldásukra, ahogy ez már a termék/szolgáltatás szekciójában is említésre került. Ezen kutatás szerint ez a célpiac helyes azonosításával kezdődik. Ha az értékesítési modell a nagykereskedelmi, vagy vállalkozók számára termékértékesítés/szolgáltatásnyújtás (B2B), akkor a piac bemutatásában prezentálni kell, pontosan mely cégek érdeklődnek a startup megoldása iránt. Ha a célpiac többszegmensü, ezeket is tisztán meg kell határozni. Ha a startup új, még nem létező piaci szegmens létrehozását tüzi ki céljául, tisztázni kell a potenciális keresletet. A startupok piackutatással sajátíthatják el ezeket az ismereteket. Ennek a mélysége és részletezettsége a három befektetési kategóriában más és más. Még az inkubációs fázisú startupoknak is el kell végezniük azt a rövid piackutatást, amelyben prezentálható a piac mérete, a legfőbb versenytársak, a piacra lépési stratégia, a belépési korlátok és bizonyos mértékü felhasználói visszajelzés. Az is előny, ha a cég már rendelkezik támogatókkal. A magvető fázisú befektetési kategóriában a befektetési menedzserek hangsúlyozták, hogy a piackutatásnak nyilvánosan elérhető adatokon kell alapulnia és alátámasztottnak kell lennie. Meg kell mutatni a piaci tendenciákat, a piaci struktúrát, a meglévő piaci szereplők százalékos piaci részesedését és árképzési erejét. Fontos a versenytársak valószínűsíthető válasza az új piacra lépésre. Nagy előny, ha a magvető fázisú cég már felvette a kapcsolatot a piaci tanácsadókkal, hogy kikérje a piaci kilátásokkal kapcsolatos véleményüket. A növekedési fázisú cégek vállalkozóinak emellett be kell bizonyítaniuk, hogy megértik a teljes piac, a célpiac és a közvetlen belépési piac közötti különbséget. 
Végezetül kiterjedtebb piaci visszajelzésre is szükség van tölük, mivel ebben a szakaszban a cég már tesztelte termékét vagy szolgáltatását.

A menedzsment csapat alapvető képességei azok a legfontosabb tulajdonságok, amelyeket a befektetési menedzserek kerestek. Az alapvető (mag, vagy „core”) képességek közé tartozhatnak a csapat képességei vagy tudása, amelyek a startup versenyelönyének forrásai. Például egy technológiai startupnál azok a szoftverfejlesztők rendelkeznek alapvető képességek jelentős részével, akik a cég fő ajánlatát jelentő szoftverterméket állítják elő. Természetesen vannak más szükséges képességek is, mint például az üzleti ismeretek, a marketing, a pénzügy stb. Lényegében a befektetési menedzserek meg akartak bizonyosodni arról, hogy az alapvető képességekkel rendelkező emberek érdekeltek-e a vállalat sikerében. Ez elsősorban úgy érhető el, hogy megfelelő részesedést biztosítanak számukra a cég saját tőkéjében. Ha azonban ők csupán alkalmazottak, és nem tőketulajdonosok, akkor a nagyobb versenytársak könnyedén elcsábíthatják ezeket a kulcsszereplöket, súlyosan aláásva a cég jövőjét. Ezért erőteljesen kritizálták azokat az üzleti terveket, amelyekben az alapító meg akarta tartani a teljes részesedést. A befektetési menedzserek szintén elfogadhatatlannak találták a „csendes partnerek”, tehát a startupban aktív szerepet nem vállaló tulajdonosok jelenlétét, mivel ez korlátozza a cég által adható részesedést a kulcsfontosságú szereplők számára, szintén korlátozva ezzel elkötelezettségüket a cég sikere iránt. Ezen kívül a vezetőségnek képesnek kell lennie arra, hogy idejének nagy részét a projektre fordítsa. Lelkesedésüknek emellett azt is sugallania kell, hogy akkor is véghez vinnék a projektet, ha nem tudnák biztosítani a külső finanszírozást.

Végezetül a pénzügyi szempontokat vizsgálva, a befektetési menedzserek észrevételei alapján a legfontosabb tulajdonság egyértelműen a vállalkozás „skálázhatósága”. A kockázati tőkés szakzsargonban a skálázható projekt fenntarthatóan tudja növelni az értékesítés volumenét, miközben alacsony marad a határköltség, így magas haszonkulcsot megtartva. Skálázható vállalkozások jellemzően a technológiai vállalatok, amelyek számára egy további ügyfél csak kis pótlólagos szerverköltséggel jár, míg a normál előfizetési díj minden ügyfélre vonatkozik. Így sokkal könnyebb támogatniuk a nagyon gyorsan növekvő felhasználói bázist. Ez a jellemző teszi a technológiai vállalatokat a kockázati tőkebefektetők kedvelt célpontjaivá. A tipikusan nem skálázható projektek általában a fizikai termékek vagy helyi személyes szolgáltatások értékesítését tervező 
startupok. Mivel ezeknek a projekteknek jelentős marginális költségeik vannak és kapacitáskorlátokkal küzdenek, amikor az értékesítési mennyiség drámaian megnőne, a kockázati tőkések finanszírozásának elnyerése ezeknek az startupoknak különösen nehéz lehet. Ezenkívül kritizálták azokat a startupokat, amelyeknél a hirdetések biztosították a kizárólagos bevételi formát. Ahhoz, hogy egy kizárólag hirdetési bevételeket realizáló startup értékes vállalattá nője ki magát, nagyon jelentős felhasználói bázis szükséges, aminek elérése rendkívül bizonytalan. A befektetési menedzserek azt is szerették volna látni, hogy a pályázók külföldi piacokra vagy végül globális piacra kívánnak lépni. A pénzügyi terv számainak bizonyítékokon kell alapulniuk, és részletezve, illetve jól alátámasztva kell szerepelniük az írott üzleti tervben. Néhány pénzügyi tervet kritizáltak az árstruktúra túlbonyolítása miatt is. "Ennek egyszerüsége azért fontos, mert értékesitenünk kell... Ha az árszerkezetet nehéz megérteni, az piacvesztéshez vezethet, mert a partnerek nem értik azt."

Ezenkívül számos megfigyelést tettek a „exitről”, a kockázati tőke saját részesedésének végső értékesítéséről. A befektetési menedzserek még az inkubációs kategóriában is nagyra értékelték, ha az üzleti tervben szerepelt a kockázati tőke exitterve. Ez azt bizonyítja, hogy az alapítók ismerik iparáguk főbb szereplőit, és hogy egy vagy több fő szereplő részéről fennáll a kereslet a startupra. Ez jelentős segítség a befektetési menedzserek számára is, mivel ennek elolvasása segíti őket a befektetésből való kilépés stratégiájának kialakításában. Másfelől, ha a lehetséges exit-lehetőségekröl nem is esik szó, akkor a kockázati tőkefinanszírozás megszerzésének esélye jelentősen csökkenhet.

Az üzleti terv általános minőségének, stílusának és szerkezetének tömörnek, tényszerünek és egyértelműnek kell lennie. A startupokat bírálták, ha a semmiről írtak hosszú, üres mondatokat. A befektetési menedzserek még az inkubációs kategóriában is hangsúlyozták, hogy elvárják minden fontosabb állítás bizonyítékokkal történő alátámasztását, ezért a hivatkozások, források összegyűjtése az üzleti terv megírása során elengedhetetlen. A növekedési kategóriában különös figyelmet fordítanak az üzleti terv általános felépítésére. „Az üzleti terv egy összetoldozott-foldozott anyagra hasonlit, ez kérdéseket vet fel az értékesitéssel kapcsolatban. Úgy tünik, hogy új partnert próbálnak bevonni egy olyan dologba, ami nem egy összefüggő egész." Ez azért is fontos, hogy a vállalkozók bebizonyítsák a kockázati tőkés számára, hogy képesek a strukturált gondolkodásra. Továbbá az 
üzleti terv stílusának koherensnek kell lennie. Ha a befektetési menedzser meg tudja állapítani, hogy a terv különböző szakaszait nagyban eltérő stílusú vagy gondolkodású személyek írták, ez hozzájárulhat a „toldozottság-foldozottság” érzetéhez. A befektetési menedzserek értékelték az üzleti tervben grafikus úton közölt információt. Azonban számos üzleti tervet kritizáltak azért, mert nagy mennyiségben alkalmaztak hívószavakat (,buzzword-öket”), megkísérelve a projekt trendiként vagy élvonalbeliként történő feltüntetését. Ezt a gyakorlatot el kell kerülni, mivel a kockázati tőkebefektetők átlátnak rajta, és a projektet saját érdemei alapján értékelik. Végezetül az üzleti terv menedzsment összefoglalójára nagy figyelem irányult, és az üzleti tervnek követnie kell a vezetői összefoglalóban meghatározott struktúrát.

Összességében tehát az üzleti tervnek bizonyítékok alapján kell előterjesztenie a pénzügyi terv minden számát, és az alapítóknak meggyőző válaszokkal kell rendelkezniük a következő kérdések mindegyikére, lehetőség szerint főként nyilvánosan elérhető adatok alapján:

- Célpiac nagysága. Ennek mekkora részét tervezi megszerezni startup, és milyen időtávon belül.

- Mely alapvető képességek teszik lehetővé a startup számára a piac részesedés megszerzését, és miként védheti meg a versenytársaktól.

- Figyelembe véve a belépési korlátokat, a szabadalmakat és a versenytársak erejét, meddig képes megtartani a piaci részesedését.

- Milyen lépéseket tervez a startup a piaci részesedés megtartása és potenciális növelése érdekében.

\section{6 Összefoglalás}

A kutatásban a magyar állami kockázati tőkebefektetők három különálló befektetési kategóriájának befektetési preferenciái közötti különbségeket vizsgáltuk az inkubációs, a magvető és a növekedési életszakaszban, mindegyikben három verbális protokoll interjút lefolytatva. Minden egyes befektetési menedzser két üzleti tervet értékelt egy interjú alatt, így összesen 18 kiértékelési interjú készült. Minden interjú egyórás volt és zavartalan körülmények között zajlott. A befektetési menedzserek kiválasztásakor a kvóta szerinti kiválasztás mintavételi módszere került alkalmazásra a reputációs alapú mintavétellel kombinálva, a legjobb általánosíthatóság érdekében az életciklus mindegyik szakaszára. A verbális 
protokoll elemzés segítségével valós időben sikerült rögzíteni az állami kockázati tőkebefektetők tényleges befektetési szürési eljárását. Ez kiküszöböli a korábbi posthoc tanulmányokhoz kapcsolható visszaemlékezési torzítást, amelyek következtetéseiket lényegében a kockázati tőkebefektetők korábbi befektetési döntéseinek esetleges hibás visszaemlékezésére alapozták. Ezen tanulmányok másik problémája a post-hoc racionalizálás, amely az egyéneket arra készteti, hogy utólag igazolják korábbi döntéseiket. Bár a verbális protokoll elemzésnek megvannak a maga hibái (legföképpen a reálisan elvégezhető verbális protokollok viszonylag alacsony száma), mégis széles körben használják conjoint elemzés mellett a kockázati tőkebefektetési döntések vizsgálatára.

A fő megállapítás az, hogy az állami kockázati tőkebefektetők összességében a vállalat pénzügyeit értékelték a leginkább. Ezt követték a magvető és a növekedési szakaszban a piac és a termék kritériumai. A szakirodalomban a privát kockázati tőkebefektetők ezzel ellentétesen a pénzügyi jellemzők elé tették a piaci jellemzőket. Ennek oka valószínủleg a szigorú állami felügyelet, amely az állami kockázati tőkebefektetőket övezi, akiknek bizonyos pénzügyi követelményeket be kell tartaniuk a befektetések kiválasztásakor. A magvető és a növekedési szakaszban a menedzsment nem volt lényeges szempontja az értékeléseknek, csak az üzleti terv minőségénél bizonyult fontosabbnak. Az, hogy a menedzsment ilyen alacsony prioritást ért el, hasonlóságot mutat a korábbi valós idejü, privát kockázati tőkebefektetési döntésekről szóló tanulmányokkal (Hall \& Hofer, 1993; Zacharakis \& Meyer, 1995; Mason \& Stark, 2004). Az inkubációs szakaszban teljesen más a helyzet: itt a vizsgált startupok legfontosabb szempontjai továbbra is a pénzügyek voltak, de a csapat megítélése szorosan második helyen állt. A menedzsment csapat fontossága a müködési előzmények hiányának tudható be. A befektetési menedzsereknek döntéseiket itt inkább a menedzsment képességeire kell alapozniuk, mint az üzleti ötletre vagy a pénzügyi adatokra, miközben az üzleti terv is nagyon rövid. Végső soron ebben a korai szakaszban a menedzsmentnek meg kell győznie a kockázati tőkebefektetőt arról, hogy valóban képesek megvalósítani a startup vállalkozást. Lényegében ebben a szakaszban az állami kockázati tőkebefektetők átveszik az angyalbefektetők néhány jellemzőjét, nevezetesen azt, hogy előnyben részesítik a meggyőző menedzsment csapatokat (Hsu et al., 2014; Mason \& Stark, 2004), miközben a legnagyobb fontosságot a cég pénzügyeinek tulajdonítják, amely minden életszakaszban a legfontosabb állami kockázati tőkebefektetők által keresett 
jellemző. Az üzleti terv minősége volt a legkevésbé fontos tulajdonság mindhárom életszakaszban, ami összhangban áll a privát kockázati tőkebefektetõk értékelésével (Hall \& Hofer, 1993; Zacharakis \& Meyer, 1995; Mason \& Stark, 2004). A kutatás alapján elmondható, hogy az állami kockázati tőkebefektetők nagy hangsúlyt fektetnek a céltársaság termékének vagy szolgáltatásának innovációs értékére, és ez a hangsúly az inkubációs szakaszban a legnagyobb. Ez összhangban áll azon állami program céljaival, amely az állami kockázati tőkebefektetők rendelkezésére bocsát forrásokat befektetés céljából.

Ebben a fejezetben három különböző életszakaszra specializálódott állami kockázati tőkebefektetési menedzserek befektetési preferenciáit ismertettük. Eredményeinket összegezve a finanszírozást kereső startupok információkat találnak benne arról, hogy mire kell törekedniük és mit kell elkerülniük a tőkefinanszírozás kérvényezése során. A tanulmány fő korlátja a magyar kockázati tőkepiaci fókusz. Más kutatók számára is hasznos lenne, hogy az országukban müködő állami kockázati tőkebefektetőket verbális protokoll elemzéssel vizsgálják, ez segítene meghatározni a földrajzi és időbeli jellemzőket, ami még mindig viszonylag kevéssé kutatott terület. További lehetséges kutatási kérdések a következők: hogyan értékelik az állami kockázati tőkebefektetők a pitch prezentációkat, milyen támogatást várhatnak a vállalkozók egy állami kockázati tőkebefektetéstől a pénzügyi támogatáson kívül, és milyen mutatók alapján értékelik az állami kockázati tőkebefektetők befektetéseik sikerét. 


\section{Következtetések, további kutatási irányok és legfontosabb eredmények}

Jelen disszertáció célja az volt, hogy feltérképezze az állami kockázati tőke szerepét a startup ökoszisztémában, megvizsgálja a magyar startup ökoszisztéma állapotát és feltárja a magyar állami kockázati tőkések döntéshozatali és befektetési preferenciáit. A disszertáció a startup ökoszisztéma fogalmának meghatározásával és az ökoszisztéma tagjainak holisztikus áttekintésével kezdődött. Ezt négy jelentős tanulmány követte, melyekben a magyar startup ökoszisztémát és az állami kockázati tőkések szerepét vizsgálatuk.

Az állami intervenciót a kockázati tőkepiacra a korai fázisú finanszírozási szegmensben meglévő tőkefinanszírozási rés indokolja. A finanszírozást kereső magvető stádiumú cégek jelentős finanszírozási nehézségekkel küzdenek. Ezt két fő piaci kudarc okozza: az aszimmetrikus információk és a tranzakciós költségek jelenléte. Mivel a magvető fázisú vállalatoknak nincsenek múltbeli pénzügyi adataik vagy piaci visszajelzésük, a befektetők számára nagyon nehéz megbecsülni a sikerük esélyét. Ezt a hatást erösíti a startup alapítói számára és a befektetők számára rendelkezésére álló információk nyilvánvaló eltérése, és az ebből következő információs aszimmetria komolyan gátolja finanszírozási lehetőségeiket. Ezen túlmenően a magvető stádiumú vállalatok kezdetben csak kis összegü befektetést igényelnek, amelynek odaítélését a hagyományos kockázati tőkealapkezelők közül sokan nem találják költséghatékonynak, mivel az alapkezelők számára minden egyes befektetési döntés nagy tranzakciós költségekkel jár, ami a befektetés nagyságától függetlenül többnyire azonos. Ezek a költségek a befektetési folyamatban részt vevő különféle szakértők, például befektetési menedzserek, kockázati szakértők, a végső befektetési döntést meghozó döntéshozó bizottság vagy igazgatóság és az portfoliókezelők fizetéséből származnak. Bizonyos befektetési méret alatt nem gazdaságos egy kockázati tőkés társaság számára, hogy magvető stádiumú cégekbe fektessen be. Ez nagy probléma, mivel e korai fázisú befektetések nélkül nehéz magas nemzeti innovációs szintet fenntartani. Ezek a piaci kudarcok, valamint a startupok által generált pozitív externáliák - mint a foglalkoztatás és az adóbevételek növelése, a regionális fejlesztés, illetve egyes esetekben a fenntartható fejlődés támogatása az innováció mellett - indokolják az államok belépését a startup finanszírozási piacra. 
A disszertációban bemutattam a magyar startup ökoszisztéma jelenlegi állapotára vonatkozó kutatásunk eredményeit. Kérdőíves megkérdezésre kerültek a magyar ökoszisztéma tagjai, amelyben nagy részvételi arányt sikerült elérni. Ebben a tanulmányban bemutattuk a hazai startup ökoszisztéma számos érdekeltjének véleményét az ökoszisztéma állapotáról. Egy kvalitatív, szisztematikus szakirodalmi összefoglaló alapján elemeztük az állami kockázati tőkével foglalkozó kutatási terület legfontosabb kutatási áramlatait többdimenziós módon kategorizálva a különféle vizsgálatok eredményeit. Ez a kutatási fejezet földrajzilag eltérő helyről származó adatforrások segítségével tárta fel az állami kockázati tőkés beavatkozások többféle típusának pozitív és negatív hatásait. Kiemelten szerepeltek az állami kockázati tőkeprogramok döntéshozóinak szóló ajánlások is ezzel megalapozva a magyar kockázati tőkepiac és a magyar állam beavatkozásának elemzési keretét.

Ezután a magyar kockázati tőkepiac és a hazai állami beavatkozások kerültek bemutatásra. Először a hazai kockázati tőkepiac korai fejlődését mutattuk be, valamint a magyar állam piacra lépési okait. Részletesen bemutatásra került a magyar állam két fö - közvetett és közvetlen - beavatkozási formája. Elöször a Jeremie program, a hazai közvetett állami beavatkozás fő formája volt az elemzés és értékelés tárgya. A program végrehajtását összevetettük a szisztematikus szakirodalmi összefoglalóban azonosított legjobb nemzetközi gyakorlatokkal. Végül a legfontosabb alapkezelö társaságok és alapok bemutatása következett, amelyek a magyar állami kockázati tőkés intervenció közvetlen formájának eszközei. A fejezet különös figyelmet szentelt a kezelt alapok céljaira, valamint a COVIC-19 járvány negatív hatásainak enyhítését célzó legújabb mentőprogramokra.

Végül a disszertációban bemutattuk a magyar kockázati tőkebefektetők preferenciáit vizsgáló kutatás eredményeit. A befektetési preferenciák a startup életciklusának inkubációs, magvető és növekedési szakaszában voltak kiértékelve, majd összehasonlítva a magánszektor kockázati tőkebefektetőinek és az angyalbefektetők preferenciáival. Az egyes preferenciakategóriákban azonosításra kerültek az állami kockázati tőkebefektetők által megfogalmazott legfontosabb kritikák is.

A kockázati tőkebefektetések terén a közép-kelet-európai régió vezető országaként Magyarország ideális helyszínnek bizonyul a startup ökoszisztéma, illetve az állami kockázati tőke ezen ökoszisztémában elfoglalt szerepének tanulmányozásához. Az eredmények segítik a kutatókat, döntéshozókat, befektetőket 
és startup vállalkozókat a hazai startup ökoszisztéma jobb megértésében. Egy lehetséges jövőbeni kutatási irány az állami kockázati tőke hatásainak feltárása, de nem a hagyományos, magánbefektetők fókuszában álló profitorientált módon, hanem olyan mérőszámok felhasználásával, amelyek jobban meg tudják ragadni annak a korai fázisú finanszírozásban jelen lévő tőkefinanszírozási rés feltöltését szolgáló eredeti célkitüzését, valamint a nemzeti stratégiai célok támogatását. Egy ilyen mérési módszertan kidolgozása segítene megmutatni az állami kockázati tőkés beavatkozás valódi hatásait, valamint javítaná az állami kockázati tőkeprogramok elszámoltathatóságát. 


\subsection{A disszertáció újszerü és részben újszerü eredményei}

A disszertációban szereplő kutatás a következő újszerü és részben újszerü eredményekkel járul hozzá a startup ökoszisztéma és az állami kockázati tőke kutatási területeihez.

1. A magyar startupperek hasonló demográfiai jellemzőkkel bírnak, mint a többi V4 országbeli társaik, ugyanakkor valamivel magasabb végzettséggel rendelkeznek. Számos hasonlóság mutatkozik a magyar startup ökoszisztéma és a V4 országok startup ökoszisztémája között: a startupok fővárosi koncentrációja, a sikertelen startupban már közremüködő startupperek százalékos aránya, a startupok külföldi piacokra való belépési szándéka, a startup finanszírozási forrásai és a startupok mérete az alkalmazottak számát tekintve.

2. Feltártuk, hogy a magyar startup ökoszisztéma tagjai mely tulajdonságokat találják a legfontosabbnak egy startup ökoszisztémában, és hogyan értékelik a magyar startup ökoszisztémát. Szerintük a legfontosabb tulajdonságokat tekintve a magyar startup ökoszisztéma közepes (finanszírozáshoz való hozzáférés, megfelelően képzett munkaerőhöz való hozzáférés, az ökoszisztéma tagjai közötti együttmüködési hajlandóság) vagy gyenge (lehetőség az újrakezdésre sikertelen startup után). Érdekes módon a legkevésbé fontos jellemzők tekintetében az ökoszisztéma értékelése a legerősebb (co-working irodaterek jelenléte, startup versenyek és társasági események, mint a „meetup” találkozók vagy networking események). A startupperek a finanszírozáshoz való hozzáférést a magyar piacon szignifikánsan gyengébbnek ítélték, mint az inkubátorok és akcelerátorok. A co-working irodák képviselői szignifikánsan magasabbra értékelték a co-working irodák jelenlétének fontosságát, mint az startupperek. A magyar startup ökoszisztéma tagjai közepesnek (elfogadhatónak) értékelték az ökoszisztéma általános erősségét.

3. Az állami kockázati tőkefinanszírozással foglalkozó kutatásoknál két fő kutatási irány figyelhető meg: az állami beavatkozás okának vizsgálata és az állami beavatkozás hatásainak feltárása. 2008 után ez utóbbi kutatási irányzat vált dominánssá a szakirodalomban, mivel a figyelem arra terelődött, hogy a különböző államok miként reagáltak a pénzügyi válságra. A tisztán állami kockázati tőke (közvetlen beavatkozás) hatása igen vitatott téma a 
szakirodalomban, a megállapítások földrajzi területtől függően eltérőek. Noha az EU-ban nem bizonyult hatékonynak, az Egyesült Államok, Thaiföld, Izrael és Dél-Korea bizonyítékai ennek ellenkezőjét mutatják. Az állami-privát kockázati tőkés partnerségeket általában hatékonynak tekintik, kivéve a közép-keleteurópai régiót, ahol e programok kivitelezése sok kritikát kapott. Az inkubációs fázisú cégek állami támogatását inkubátorok és üzleti angyalok finanszírozása által szinte kizárólag pozitívan értékelték a hatást vizsgáló szerzők. Nem véletlen, hogy az állami beavatkozás az inkubációs és a magvető fázisú finanszírozás ágazatában a leginkább indokolt.

4. Az állami kockázati tőkeprogramok kutatóinak ajánlásait összegeztük. Az állami kockázati tőkeprogramoknak nem szabad versenyezniük egymással, elszámoltathatónak kell lenniük, támogatniuk kell a céltársaságokat az egész életciklusuk alatt, közvetett ösztönzőket kell alkalmazni a privát kockázati tőkések motiválására, az államnak a vállalkozók oktatására kell összpontosítania a piac keresleti oldalának javítása érdekében, és hagyniuk kell, hogy regionális intézmények intézzék a regionális fejlesztésre szánt források elosztását.

5. A magyar állam a Jeremie program révén közvetett beavatkozást alkalmazott a hazai kockázati tőkepiacon. A program növelte a rendelkezésre álló kockázati tőkekínálatot, és segített a piac élénkítésében a 2008-as válság után, de kivitelezését a kutatók élesen kritizálták. A program nem érte el sem a regionális fejlesztéssel, sem a korai stádiumban lévő, a finanszírozásra leginkább rászoruló vállalatok támogatásával kapcsolatos célját. Kritizálták az alapkezelő társaságok kiválasztási folyamatát, valamint a kockázati tőkebefektetők által a céltársaságokban megszerzett többségi részesedést is. Kimutatták, hogy a program során végrehajtott befektetések kevésbé voltak hatékonyak a céltársaságok növekedésének elősegítésében, mint a közvetlen állami kockázati tőkebefektetések. Ezen kívül a program nem követte a legjobb nemzetközi gyakorlatokat.

6. A magyar állam közvetlen beavatkozást alkalmazott különböző alapkezelő társaságai és alapjai révén. A beavatkozás eredeti célja a tőkefinanszírozási rés betöltése volt az életciklus legkorábbi szakaszában, ahol a privát kockázati tőkebefektetők vonakodtak befektetni. Ezt később kiegészítették olyan nemzeti stratégiai célokkal, mint a regionális fejlesztés és az egyéb pozitív externáliákat 
generáló vállalatok támogatása. A közelmúltban az állam közvetlen kockázati tőkés intervenciója elkezdte elősegíteni a COVID-19 járvány hazai vállalatokra gyakorolt negatív hatásainak enyhítését.

7. Feltártuk az állami kockázati tőkebefektető befektetési preferenciáit: A potenciális befektetési céltársaságok üzleti terveinek elemzésekor az állami kockázati tőkebefektetők leginkább a céltársaság pénzügyi számait értékelik a társaság életszakaszától függetlenül. Az inkubációs fázisú üzleti tervek elemzésekor az angyalbefektetők preferenciái jellemzik, mivel a pénzügyi jellemzőket a menedzsment csapat képességeivel egészítik ki a legmagasabbra értékelt jellemzők között. A magvető és növekedési stádiumú vállalatok esetében a pénzügyi, majd a piachoz kapcsolódó tulajdonságokat értékelik a legjobban, míg a privát kockázati tőkések esetében ez fordítva van. Ez nagy valószínüséggel annak a magas szintü állami felügyeletnek a következménye, amely alatt müködnek, és emiatt bizonyos pénzügyi követelményeket kell szem előtt tartaniuk a befektetések kiválasztásakor. Arról is elökerült bizonyíték, hogy az állami kockázati tőkebefektetők nagy hangsúlyt fektetnek a céltársaság termékének vagy szolgáltatásának innovációs értékére, ez a hangsúly az inkubációs szakaszban a legnagyobb.

8. Az állami kockázati tőkebefektetők igen kritikusan fogadják a beérkezett üzleti terveket. A startupok üzleti terveit élesen kritizálták az innovációs érték hiánya, a vezetőség motivációjának és elkötelezettségének hiánya, a gyenge piacelemzés és a megalapozatlan pénzügyi elörejelzések miatt. Így az induló vállalkozásoknak nagy hangsúlyt kell fektetniük az üzleti tervre igen kritikus kiértékelésre számítva. 


\section{Irodalomjegyzék}

Akerlof, G. A. (1978): The market for "lemons": Quality uncertainty and the market mechanism. In Uncertainty in economics (pp. 235-251). Academic Press.

Alperovych, Y., Hübner, G., Lobet, F. (2015): How does governmental versus private venture capital backing affect a firm's efficiency? Evidence from Belgium. Journal of Business Venturing, 30(4), 508-525. doi:10.1016/j.jbusvent.2014.11.001

Aman, S., Lovas, A. (2015): Overcoming Asymmetric Information in Venture Capital Finance: Theoretical approach and evaluation of Hungarian findings. Studies in International Economics: Special Issue of Külgazdaság, 1(2), 3-22.

Aranyossy, M., Blaskovics, B., Horváth, Á. A. (2018): How universal are IT project success and failure factors? Evidence from Hungary. Information Systems Management, 35(1), 15-28. doi: 10.1080/10580530.2017.1416943.

Avnimelech, G., Schwartz, D., Bar-El., R. (2007): Entrepreneurial High-tech Cluster Development: Israel's Experience with Venture Capital and Technological Incubators. European Planning Studies, 15(9), 1181-1198. doi:10.1080/09654310701529078

Avnimelech, G. (2008): A five-phase entrepreneurial oriented innovation and technology policy profile: The Israeli experience. European Planning Studies, 16(1): 81-98. doi: 10.1080/09654310701747985

Balboni, B., Bortoluzzi, G., Tivan, M., Tracogna, A., Venier, F. (2014): The Growth Drivers of Start-up Firms and Business Modelling: A First Step toward a Desirable Convergence. Management, 9(2), 131-154.

Baldock, R., C. Mason. (2015): Establishing a new UK finance escalator for innovative SMEs: the roles of the Enterprise Capital Funds and Angel CoInvestment Fund. Venture Capital, 17(1-2), 59-86. doi:10.1080/13691066.2015.1021025

Bandara, W., S. Miskon, E. Fielt. (2011): A systematic, tool-supported method for conducting literature reviews in information systems. In Proceedings of the19th European Conference on Information Systems (ECIS 2011).

Bankár Magazin (2020): MFB: Összehangolt hitel-, töke- és garanciaprogramok indulnak, közel 1500 milliárd forint értékben. https://bankarmagazin.hu/2020/04/23/mfb-osszehangolt-hitel-toke-esgaranciaprogramok-indulnak-kozel-1500-milliard-forint-ertekben Letöltés ideje: 2020.09.19

Bauer, E., H. P. Burghof. (2007): The economics of state subsidies in early stage financing. International Journal of the Economics of Business, 14(3), 433-457. doi:10.1080/13571510701597353

Beauchamp, M., Skala, A. (2017): Visegrad Startup Report 2016/2017. Warszawa: Startup Poland. https://s3.eu-central1.amazonaws.com/uploads.mangoweb.org/sharedprod/aspeninstitutece.org/uploads/2017/06/Visegrad-Startup-Report-5.pdf Letöltés ideje: 2020.04 .11

Berger, A. N., Udell, G. F. (1988): The economics of small business finance: The roles of private equity and debt markets in the financial growth cycle. Journal of Banking \& Finance, 22(6), 613-673. 
Berlinger, E., Lovas, A., Juhász, P. (2017): State subsidy and moral hazard in corporate financing. Central European Journal of Operations Research, 25(4), 743-770. doi:10.1007/s10100-016-0461-8

Berlinger, E. (2019): How does the state destroy incentives in innovation financing? Economy and Finance: English-Language Edition of Gazdaság és Pénzügy, 6(3), 226-243. https://doi.org/10.33908\%2FEF.2019.3.1

Bilau, J., C. Mason, T. Botelho, S. Sarkar. (2017): Angel investing in an austerity economy - the take-up of government policies in Portugal. European Planning Studies, 25(9): 1516-1537. doi:10.1080/09654313.2017.1328045

Brander, J. A., Du, Q., Hellmann, T. F. (2015): The Effects of GovernmentSponsored Venture Capital: International Evidence. Review of Finance, 19 (2), 269-290.

Brander, J. A., Egan, E., Hellmann, T. F. (2008): Government Sponsored Versus Private Venture Capital: Canadian Evidence. National Bureau of Economic Research, Cambridge.

Bruno, A.V., Tyebjee, T.T. (1983): The one that got away: A study of ventures rejected by capitalists. In Frontiers of Entrepreneurship Research. Proceedings of the 1983 Conference on Entrepreneurship, szerk: J. A. Hornaday, J. A. Timmons, K. H. Vesper, pp. 289-306, Wellesley: Babson College.

Callagher, L. J., P. Smith, S. Ruscoe. (2015): Government roles in venture capital development: a review of current literature. Journal of Entrepreneurship and Public Policy, 4(3), 367-391. doi:10.1108/JEPP-08-2014-0032

Chiu, I., Shu, L. H. (2010): Potential limitations of verbal protocols in design experiments. In ASME 2010. International Design Engineering Technical Conferences and Computers and Information in Engineering Conference, pp. 287-296. Montreal, Canada: American Society of Mechanical Engineers.

Cho, J. Y., E. Lee. (2014): Reducing Confusion about Grounded Theory and Qualitative Content Analysis: Similarities and Differences. The Qualitative Report, 19(32), 1-20. http://www.nova.edu/ssss/QR/QR19/cho64.pdf

Cohen, E., J. Gabbay, D. Schiffman. (2012): The Office of the Chief Scientist and the financing of high tech research and development, 2000-2010. Israel Affairs, 18(2), 286-306. doi:10.1080/13537121.2012.659082

Colombo, M. G., Cumming, D. J., Vismara, S. (2016): Governmental venture capital for innovative young firms. Journal of Technology Transfer, 41(1), 10-24. doi:10.1007/s10961-014-9380-9

Csepy, G., Kovács, N., Jáki, E. (2020): Crowdfunding Campaigns and Success: A Systematic Literature Review. In: Daszyńska-Żygadło, K.; Bem, A.; Ryszawska, B.; Jáki, E.; Hajdíková, T. (szerk.): Finance and Sustainability: Proceedings from the 2nd Finance and Sustainability Conference, Wroclaw 2018. Cham, Switzerland: Springer International Publishing, pp. 181-190.

Cumming, D. (2007): Government policy towards entrepreneurial finance: Innovation investment funds. Journal of Business Venturing, 22(2), 193-235. doi:10.1016/j.jbusvent.2005.12.002

Cumming, D., S. Johan. (2009): Pre-seed government venture capital funds. Journal of International Entrepreneurship, 7(1), 26-56. doi:10.1007/s10843-008-0030-x

Cumming, D., L. Grilli, S. Murtinu. (2017): Governmental and independent venture capital investments in Europe: A firm-level performance analysis. Journal of Corporate Finance, 42, 439-459. doi:10.1016/j.jcorpfin.2014.10.016

Czyżewska, M., Mroczek, T., Lewicki, A., Cwynar, A. (2016): The study of entrepreneurship growth drivers with the application of bayesian networks and 
global data. Humanitas University's Research Papers Management, 17(4), 129146. https://doi.org/10.5604/18998658.1232692

Damodaran, A. (2009): Valuing Young, Start-Up and Growth Companies: Estimation Issues and Valuation Challenges. SSRN Electronic Journal, (May), 1-67. doi:10.2139/ssrn.1418687

Daszyńska-Żygadło, K., T. Słoński, M. Ligus. (2016): Investment in renewable energy technologies from the perspective of polish venture capital Funds. In: European Financial Systems 2016. Proceedings of the 13th International Scientific Conference, szerk: J. Krajíček, J. Nesleha, and K. Urbanovsky, 79-85, Brno: Masaryk University. https://is.muni.cz/do/econ/sborniky/2016/EFS2016Proceedings_final_September_19_final.pdf

Dávid, Sz. D., Becsky-Nagy, P. (2016): A kockázati tőkebefektetők kiválasztási kritériumai. Controller info, 4(1), 22-29.

Deloitte Zrt. (2016): MFB Zrt. részére a 3-as tematikus célkitüzéshez kapcsolódó exante tanulmány. Deloitte Zrt., Budapest.

Dong, Y. Men, C. (2014): SME Financing in Emerging Markets: Firm Characteristics, Banking Structure and Institutions. Emerging Markets Finance and Trade, 50(1), 120- 149. doi: 10.2753/REE1540-496X500107

Dorsey, T. (1979): Operating Guidelines for Effective Venture Capital Funds Management. $\mathrm{IC}^{2}$ Institute, The University of Texas at Austin. http://hdl.handle.net/2152/27758

Dzurovčinová, P. (2016): Slovak Startups Report 2016. https://www.slideshare.net/PetraDzurovcinova2/slovak-startups-report-2016part-of-v4-startup survey-1-71950526 Letöltés ideje: 2018.12.01.

Equinox Consulting (2016): Kockázatitőke-programok eddigi eredményeinek értékelése. Miniszterelnökség, Budapest. https://www.palyazat.gov.hu/download.php?objectId=71217 Letöltés ideje: 2020.08.30.

Ericsson, K. A., H. A. Simon (1993): Protocol analysis: Verbal reports as data. (Rev. ed.). Cambridge: The MIT Press.

Fazekas, B. (2018): Élet a piacon túl-Az állami hátterü kockázatitöke-finanszírozás elmélete és gyakorlata a magyarországi tapasztalatok tükrében. Doktori értekezés, Debrecen.

Fazekas, B., Becsky-Nagy, P. (2018): Az állam a kockázati tőkés szerepében. Közgazdasági Szemle, 65(12), 1257-1280. doi:10.18414/KSZ.2018.12.1257

Fazekas, B., Becsky-Nagy, P. (2019): Mit jelez a tulajdonosi szerkezet? - A tulajdonosi szerkezet és a vállalkozások teljesítményének kapcsolata információs aszimmetriák mellett a magyarországi kockázati tőkebefektetések tükrében. Vezetéstudomány-Budapest Management Review, 50(7-8), 31-38. doi:10.14267/VEZTUD.2019.07.03

Fazekas, B. Becsky-Nagy, P. (2020): Conceptualizing government venture capital agendas: The theoretical model of government backed venture capital funding. Under publication.

Forbes (2020): The state helps startups with new investment fund and two rescue programs. $\quad$ https://forbes.hu/uzlet/uj-befektetesi-alappal-es-ketmentoprogrammal-segit-az-allam-a-startupoknak Letöltés ideje: 2020.09.19

Frenkel, A., D. Shefer, M. Miller (2008): Public versus Private Technological Incubator Programmes: Privatizing the Technological Incubators in Israel. European Planning Studies, 16(2), 189-210. doi:10.1080/09654310701814504 
Gill, D. E. (2015): Consolidating the gains. Venture Capital, 17(1-2), 43-58. doi:10.1080/13691066.2015.1021029

Grilli, L., S. Murtinu (2014): Government, venture capital and the growth of European high-tech entrepreneurial firms. Research Policy, 43(9), 1523-1543. doi:10.1016/j.respol.2014.04.002

Guerini, M., A. Quas (2016): Governmental venture capital in Europe: Screening and certification. Journal of Business Venturing, 31(2), 175-195. doi:10.1016/j.jbusvent.2015.10.001

Hall, J., and C. W. Hofer (1993): Venture capitalists' decision criteria in new venture evaluation. Journal of Business Venturing, 8(1), 25-42. doi: 10.1016/08839026(93)90009-T

Harpe, S. E. (2015): How to analyze Likert and other rating scale data. Currents in Pharmacy Teaching and Learning, 7(6), 836-850. doi: 10.1016/j.cptl.2015.08.001.

Harrison, R. T., C. Mason, D. Smith (2015): Heuristics, learning and the business angel investment decision-making process. Entrepreneurship \& Regional Development 27(9-10), 527-554. doi: 10.1080/08985626.2015.1066875

Heger, D., A. Fier, G. Murray (2005): Review essay: regional venture capital policy: UK and Germany compared. Venture Capital 7(4), 373-383. doi:10.1080/13691060500138756

Herrera-Echeverri, H., J. Haar, J. B. Estevez-Bretón (2014): Foreign investment, institutional quality, public expenditure, and activity of venture capital funds in emerging market countries. Global Economy Journal, 14(2), 127-162. doi:10.1515/gej-2013-0068

Herzberg, F. (2017): Motivation to work. Abingdon-on-Thames, UK: Routledge.

Hiventures (2018): Újragondolt befektetési programokkal várja a startupokat a Hiventures. https://startup.hiventures.hu/hu/hirek/sajto/ujragondolt-befektetesiprogramokkal-varja-a-startupokat-a-hiventures. Letöltés ideje: 2020.09.16.

Hiventures (2019): Tőkefinanszírozás a magyar kisvállalatoknak: 31 milliárdos program indult! https://kkvpro.hiventures.hu/hu/hirek/tokefinanszirozas-amagyar-kisvallalatoknak_-31-milliardos-program-indult Letöltés ideje: 2020.09.16.

Horváth, D., A. Mitev (2015): Alternativ kvalitatív kutatási kézikönyv. Budapest: Aliena Kiadó.

Hsu, D. K., J. M. Haynie, S. A. Simmons, A. McKelvie (2014): What matters, matters differently: a conjoint analysis of the decision policies of angel and venture capital investors. Venture Capital, 16(1), 1-25. doi: 10.1080/13691066.2013.825527

HUNBAN - Hungarian Business Angel Network (2020): Hivatalos weboldal. https://hunban.eu Letöltés ideje: 2020.07.26.

HVCA (2014): Elemzés a hazai kockázati tőkealap-kezelők és alapok müködéséről. Hungarian Private Equity and Venture Capital Association. http://www.hvca.hu/wpcontent/uploads/2015/02/Elemzes_a_kovkazati_tokealapkezeloi_szektorrol_020 2.pdf. Letöltés ideje: 2017.05.01.

HVCA (2014, 2015, 2016, 2017): Hungarian Venture Capital Association Investment Monitoring Report. Hungarian Private Equity and Venture Capital Association. http://www.hvca.hu/hu/statisztika Letöltés ideje: 2017.05.01.

Innovációs és Technológiai Minisztérium (2013): Az Új Széchenyi Kockázati Tökeprogramok Közös Növekedési Alap Alprogram pályázati felhívásának 
eredményhirdetése.

https://www.palyazat.gov.hu/az_uj_szechenyi_kockazati_tokeprogramok_kozos _novekedesi_alap_alprogram_palyazati_felhivasanak_eredmenyhirdetese

Letöltés ideje: 2016.10.30

Invest Europe (2017): European Private Equity Activity Data 2016. https://www.investeurope.eu/media/652475/yearbook-2016-europe-and-countryoverview-tables-member-version-20170510.xlsx Letöltés ideje: 2017.05.01.

Invest Europe (2019): Central and Eastern Europe Statistics 2018. https://www.investeurope.eu/media/2630/ie_cee_report_2018_final.pdf Letöltés ideje: 2020.01.17.

Invest Europe (2020): Central and Eastern Europe Statistics 2019. https://www.investeurope.eu/media/3225/central_and_eastern_europe_activity_r eport_2019.pdf Letöltés ideje: 2020.01.17.

Jáki, E. (2010): Illusion of knowledge in financial planning, 2010. marc Spring Wind 2010 Conference proceedings, Pécs, ISBN: 978-615-5001-05-5 2010: 183-188

Jáki, E., Molnár, E. M. (2017): Model of the state and EU involvment in the venture capital market. In: Proceedings 31st European Conference on Modelling and Simulation ECMS 2017. ECMS-European Council for Modelling and Simulation, Nottingham, pp. 120-126. ISBN: 978-0-9932440-4-9

Jáki, E., Molnár, E. M., Kádár, B. (2019): Characteristics and challenges of the Hungarian startup ecosystem. Vezetéstudomány - Budapest Management Review, 50(5), 2-12. doi: 10.14267/VEZTUD.2019.05.01

Jaki, E., Molnar, E. M., Walter, Gy. (2017): Government Sponsored Venture Capital: Blessing Or Curse? Management (Slovenia), 12(4), 317-331. doi: 10.26493/1854-4231.12.317-331

Jung, K., J-H. Eun, S-H. Lee (2017): Exploring competing perspectives on government-driven entrepreneurial ecosystems: lessons from Centres for Creative Economy and Innovation (CCEI) of South Korea. European Planning Studies 25(5), 827-847. doi:10.1080/09654313.2017.1282083

Kállay, L. \& Jáki, E. (2019): The impact of state intervention on the Hungarian venture capital market. Economic research-Ekonomska istraživanja, 1-16. doi:10.1080/1331677X.2019.1629979

Karsai, J. (1997): A kockázati tõke lehetõségei a kis- és középvállalatok finanszírozásában. Közgazdasági Szemle, 44(2), 165-174.

Karsai, J. (2002): Mit keres az állam a kockázati tőkepiacon? A kockázati tőke állami finanszírozása Magyarországon. Közgazdasági Szemle, 49(11), 928-942.

Karsai, J. (2004): Does state replace private investors? The role of state on venture capital market. MTA Center of Economic and Regional Studies. Working paper. Budapest.

Karsai, J. (2011A): Development of the Hungarian venture capital and private equity industry over the past two decades. In: Jubilee 20 Years Yearbook, Hungarian Venture Capital and Private Equity Association, Bp. 2011, pp. 22-44.

Karsai, J. (2011B): A kockázati tőke két évtizedes fejlődése Magyarországon. Közgazdasági Szemle, 58(10), 832-857.

Karsai, J. (2012): A kapitalizmus új királyai: Kockázati töke Magyarországon és a közép-kelet-európai régióban. Közgazdasági Szemle Alapítvány-MTA Közgazdaság-és Regionális Tudományi Kutatóközpont Közgazdaság-tudományi Intézet.

Karsai, J. (2013): Válság után: változó állami szerep a kockázatitőke-ágazatban. Külgazdaság. 57 (5-6), 12-34. 
Karsai, J. (2016): A magyarországi kockázatitőke-alapkezelők véleménye a Jeremie kockázatitöke-programról. Marketing \& Menedzsment, 50(3-4), 33-42.

Karsai, J. (2017a): Furcsa pár. Az állam szerepe a kockázati tökepiacon KeletEurópában. Budapest, Hungary: Közgazdasági Szemle Alapítvány - MTA Közgazdaság- és Regionális Tudományi Kutatóközpont Közgazdaságtudományi Intézet.

Karsai, J. (2017b): Az állam kockázati tőkepiaci részvételének átláthatósága magyarországon. Közgazdasági Szemle, 64(12), 1316-1342.

Karsai, J. (2018): Government venture capital in central and eastern Europe. Venture Capital 20 (1): 73-102. doi:10.1080/13691066.2018.1411040

Karsai, J. (2019): Szakirodalmi áttekintés a korai fázisú, gyorsan növekvő innovatív vállalkozások tőkefinanszírozását segítő alternatív megoldásokról. Literature review on the alternative methods to enhance equity finance of early-stage highgrowth innovative ventures. Mühelytanulmányok - Discussion Papers (MT-DP2019/22), Közgazdaság- és Regionális Tudományi Kutatóközpont Közgazdaságtudományi Intézet, Budapest.

Karsai, J. (2020): Propped up by the Government: The Recent Evolution of the EarlyStage Equity Finance Market in Hungary. In: Entrepreneurial Finance in Emerging Markets (pp. 251-267). Palgrave Macmillan, Cham.

Karsai, J., Baranyai, G. (2005): A kockázati-és magántőkeipar fejlödése Magyarországon 1989-2004. Magyar Kockázati és Magántőke Egyesület, Budapest, 2005.

Khan, A. M. (1987): Assessing venture capital investments with noncompensatory behavioral decision models. Journal of Business Venturing, 2(3), 193-205. doi: 10.1016/0883-9026(87)90008-5

Kim, W. C., Mauborgne, R. (2004): Blue Ocean strategy. Harvard Business Review, 2004 Oct., 76-84.

Kirsch, D., Goldfarb, B., Gera, A. (2009): Form or substance: the role of business plans in venture capital decision making. Strategic Management Journal, 30(5), 487-515.

Kollmann, T., Stöckmann, C., Hensellek, S. Kensbock, J. (2016): European startup Monitor 2016. Essen, Germany: German Startups Association. ISBN: 978-3938338-17-9

Korosteleva, J., Mickiewicz, T. (2011): Start-up Financing in the Age of Globalization. Emerging Markets Finance and Trade, 47(3), 23-49. doi: $10.2307 / 23047087$.

Kovács, B. (2011): Állami kockázati tőke a magyar kkv-finanszírozásban. Disszertáció, Széchenyi István Egyetem, Regionális és Gazdaságtudományi Doktori Iskola, Győr, 2011.

KPMG (2016): Startup Ecosystem Survey Slovakia 2016. https://assets.kpmg/content/dam/kpmg/pdf/2016/06/startup-ecosystem-surveyslovakia-2016.pdf Letöltés ideje: 2020.08.12)

Labovitz, S. (1967): Some observations on measurement and statistics. Social Forces, 46(2), 151-160. doi: 10.2307/2574595.

Liu, H., Wang, Y. (2018): The Value of Crowdfunding: An Explanation Based on Demand Uncertainty and Comparison with Venture Capital. Emerging Markets Finance and Trade, 54(4), 783-791. doi: 10.1080/1540496X.2018.1434619.

Lovas, A. (2015): Innováció-finanszírozás asszimetrikus információs helyzetben. Az állami beavatkozás hatása. Disszertáció, Budapesti Corvinus Egyetem, Budapest, 2015. 
Lovas, A. (2015): The Risk of Adverse Selection and its Management in the Process of Venture Capital Investment. Economy and Finance: English-Language Edition of Gazdaság és Pénzügy, 2(2), 186-202. http://unipub.lib.unicorvinus.hu/2070/1/EF2015v2n2p186eng.pdf

Lovas, A., Riz, N. (2016): Accelerator or incubator? Enterprise support organisations in Hungary in light of international practice. Economy and Finance, 3(4), 305322.

Lovas, A., Illés, R. (2018): A hazai kockázati tőkebefektetések értékelése, különös tekintettel a JEREMIE-alapok befektetéseire. Külgazdaság, 62, 30-55. http://real-j.mtak.hu/12768/4/2018_K\%C3\%BClg7-8.pdf\#page=30

Luukkonen, T., Deschryvere, M., Bertoni, F. (2013): The Value Added by Government Venture Capital Funds Compared with Independent Venture Capital Funds. Technovation, 33(4-5), 154-162. doi:10.1016/j.technovation.2012.11.007

Macmillan, I. C., L. Zemann, P. N. Subbanarasimha (1987): Criteria distinguishing successful from unsuccessful ventures in the venture screening process. Journal of Business Venturing, 2(2), 123-137. doi: 10.1016/0883-9026(87)90003-6

Mason, C., T. Botelho (2016): The role of the exit in the initial screening of investment opportunities: The case of business angel syndicate gatekeepers. International Small Business Journal, 34(2), 157-175. doi: $10.1177 / 0266242614563419$

Mason, C., M. Stark (2004): What do investors look for in a business plan? A comparison of the investment criteria of bankers, venture capitalists and business angels. International Small Business Journal, 22(3), 227-248. doi: 10.1177/0266242604042377

Mayring, P. (2004): Qualitative content analysis. In: A companion to qualitative research, szerk: Flick, U., von Kardoff E., Steinke, I., 159-176, London: SAGE.

MFB (2020): MFB Csoport Programok. https://www.mfb.hu/gazdasagelenkitess2436 Letöltés ideje: 2020.09.19.

MFB Invest (2019): Magyarországon indul az elsö európai vízalap,

a Water Impact Fund. https://mfbinvest.hu/kozlemenyek/magyarorszagon-indul-azelso-europai-vizalap-a-water-impact-fund Letöltés ideje: 2020.09.14.

MFB Invest (2020a): Cégbemutató. https://mfbinvest.hu/rolunk/cegbemutato Letöltés ideje: 2020.09.11.

MFB Invest (2020b): Sajtószoba. https://mfbinvest.hu/sajtoszoba Letöltés ideje: 2020.09.11.

MFB Invest (2020c): Elstartolt a debreceni Városi Tőkealap. https://mfbinvest.hu/kozlemenyek/elstartolt-a-debreceni-varosi-tokealap Letöltés ideje: 2020.09 .11$.

MFB Invest (2020d): Elindul a Székesfehérvári Városi Alap. https://mfbinvest.hu/kozlemenyek/elindul-a-szekesfehervari-varosi-alap Letöltés ideje: 2020.09.11.

MFB Invest (2020e): Tematikus tökealapot indit az MFB Csoport Kaposváron. https://mfbinvest.hu/kozlemenyek/tematikus-tokealapot-indit-az-mfb-csoportkaposvaron Letöltés ideje: 2020.09.11.

MFB Invest (2021): Tökealapok. https://mfbinvest.hu/finanszirozasiszolgaltatasaink/tokealapok/ Letöltés ideje: 2021.04.23.

Milosevic, M. (2018): Skills or networks? Success and fundraising determinants in a low performing venture capital market. Research Policy, 47(1), 49-60. doi:10.1016/j.respol.2017.09.009 
Miniszterelnökség (2016): Digital Startup Strategy of Hungary. http://www.kormany.hu/download/2/4b/21000/The\%20Digital\%20Startup\%20S trategy\%20of\%20Hungary.pdf Letöltés ideje: 2018.12.01.

MNB (2015): Elemzés a hazai kockázati tőkealap-kezelök és alapok müködéséröl. https://www.mnb.hu/letoltes/elemzes-a-kovkazati-tokealapkezeloi-szektorrol0202.pdf Letöltés ideje: 2017.05.26.

Molnár, E., Jáki, E. (2020): What qualities do government-owned venture capital investors seek in a new venture? A comparison of investment criteria across preseed, seed, and expansion stage startups. Vezetéstudomány - Budapest Management Review, 51(11), 64-76. doi:10.14267/VEZTUD.2020.11.06

Morawska, K. (2015): The Startup Ecosystem in Poland. https://www.startupbridge.eu/wp-content/uploads/2019/02/startup ecosystem-inpoland-.pdf Letöltés ideje: 2020.08.12.

Muzyka, D., S. Birley, B. Leleux (1996): Trade-offs in the investment decisons of European venture capitalists. Journal of Business Venturing, 11(4), 273-287. doi: 10.1016/0883-9026(95)00126-3

MV Zrt. (2013): Új Magyarország Kockázati Tőke Program és Új Széchenyi Kockázati Tőke Program. Magyar Vállalkozásfinanszírozási Zrt., Budapest. http://www.mvzrt.hu/termekek/kockazati-toke/ujmagyarorszag-kockazati-tokeprogram-es-ujszechenyi-kockazati-toke-program Letöltés ideje: 2016.10.30.

OVM (2020): Országos Vállalkozói Mentorprogram, Rövid ismertetö. https://www.vallalkozztudatosan.hu/?page_id=270 Letöltés ideje: 2020.08.01.

Paliszkiewicz, J. O. (2011): Trust Management: Literature Review. Management, 6(4), 315-331.

Palyazat.gov.hu (2012): GOP-2012-4.3/A. https://www.palyazat.gov.hu/doc/3531 Letöltés ideje: 2016.10 .30 .

Palyazat.gov.hu (2014): 2014-2020-as operativ programok társadalmi egyeztetése. https://www.palyazat.gov.hu/node/54899 Letöltés ideje: 2019.01.25.

Palyazat.gov.hu (2016): GINOP-8.1.3/A-16 termékleirás. https://www.palyazat.gov.hu/ginop-813-a-16-nemzeti-technolgiai-s-szellemitulajdon-kockzati-tkeprogram Letöltés ideje: 2021.05.05.

Palyazat.gov.hu (2017): GINOP-8.2.3-17 https://www.palyazat.gov.hu/ginop-823-17-specializlt-seed-s-pre-seedbefektetsi-tkealap-indul-ikt-vllalkozsok-szmra-j-tletekhez-j-piacra-lpshezkockzati-tkeprogram-1\# Letöltés ideje: 2020.09.18.

Paré, G., M-C. Trudel, M. Jaana, S. Kitsiou (2015): Synthesizing information systems knowledge: A typology of literature reviews. Information \& Management, 52(2), 183-199. doi:10.1016/j.im.2014.08.008

Paschen, J. (2017): Choose wisely: Crowdfunding through the stages of the startup life cycle. Business Horizons, 60(2), 179-188. doi: 10.1016/j.bushor.2016.11.003

Pintér, A. (2021): A Hiventures Zrt. Startup és KKV Mentöprogramjai ügyvédi szemmel. http://pinterlaw.hu/a-hiventures-zrt-startup-es-kkv-mentoprogramjaiugyvedi-szemmel Letöltés ideje: 2021.05.07

Prim Online (2018): Indulnak az új Jeremie-alapok. http://hirek.prim.hu/cikk/2018/10/28/indulnak_az_uj_jeremiealapok_80_milliard_forint_friss_forras_erheto_el_innovaciora Letöltés ideje: 2020.10 .15

Robinson, R. B. (1987): Emerging strategies in the venture capital industry. Journal of Business Venturing, 2(1), 53-77. doi: 10.1016/0883-9026(87)90019-X 
Roman, A., Bilan, I., Ciumas, C. (2018): What Drives the Creation of New Businesses? A Panel-Data Analysis For EU Countries. Emerging Markets Finance and Trade, 54(3), 508- 536. doi: 10.1080/1540496X.2017.1412304.

Sahlman, W. A. (1997): How to Write a Great Business Plan. Harvard Business Review, 75, 98-108.

Sahlman, W. A., Scherlis, D. R. (2009): A Method For Valuing High-Risk, LongTerm Investments: The Venture Capital Method. Harvard Business School Background Note. https://www.hbs.edu/faculty/Pages/item.aspx?num=6515

Sandberg, W. R., C. W. Hofer. (1987): Improving new venture performance: The role of strategy, industry structure, and the entrepreneur. Journal of Business Venturing, 2(1), 5-28. doi: 10.1016/0883-9026(87)90016-4

Sandberg, W. R., D. M. Schweiger, C. W. Hofer (1988): The Use Of Verbal Protocols in Determining Venture Capitalists Decision Processes. Entrepreneurship Theory and Practice, 13(2), 8-20.

Shepherd, D. A. (1999): Venture Capitalists Assessment of New Venture Survival. Management Science, 45(5), 621-632. doi: 10.1287/mnsc.45.5.621

Shimasaki, C. (2020). Mentorship: Why You Need a Team of Mentors to be Successful. In Biotechnology Entrepreneurship (pp. 113-120). Academic Press. Skala, A., Kruczkowska, E. (2016): Polish Startups Report 2016. http://startuppoland.org/wp-content/uploads/2016/09/Startup-Poland-Raport2016-03-ENG.pdf Letöltés ideje: 2018.12.01.

Smith, D., R. T. Harrison, C. Mason (2010): Experience, heuristics and learning: the angel investment process. Frontiers of Entrepreneurship Research, 30(2). http://digitalknowledge.babson.edu/fer/vol30/iss $2 / 3$

Stadnicka, D., Sakano, K. (2017): Employees Motivation and Openness for Continuous Improvement: Comparative Study in Polish and Japanese Companies. Management and Production Engineering Review, 8(3), 70-86. doi:10.1515/mper-2017-0030.

Standaert, T., S. Manigart (2018): Government as fund-of-fund and VC fund sponsors: effect on employment in portfolio companies. Small Business Economics, 50(2), 357-373. doi:10.1007/s11187-016-9831-9

Staszkiewicz, M., Havliková, D. (2016): Czech Startups Report 2016. https://www.aspeninstitutece.org/project/czech-startup-report Letöltés ideje: 2018.12.01.

Századvég (2016): Pénzügyi eszközök értékelése. Századvég Gazdaságkutató Zrt., Budapest. https://www.palyazat.gov.hu/gazdasgfejlesztsi-expost-rtkelsek Letöltés ideje: 2020.08.31.

Szentes, T. (2006): Az állam szerepe a felgyorsult globalizációban. Közgazdaság, 1, $15-45$.

SZTA (2020): SZTA weboldal. https://www.szta.hu/nyito. Letöltés ideje: 2020.09.16.

Timilsina, B., Forsén, N., Takala, J. Malek, N. A. A. (2016): Which one to choose multi focus or trade-off among competitive priorities? Evidence from Finnish SMEs. Management and Production Engineering Review, 7(1), 77-88. doi:10.1515/mper-2016-0009.

Tripathi, N., Oivo, M. (2020): The Roles of Incubators, Accelerators, Co-working Spaces, Mentors, and Events in the Startup Development Process. In Fundamentals of Software Startups (pp. 147-159). In: Nguyen-Duc A., Münch J., Prikladnicki R., Wang X., Abrahamsson P. (szerk): Fundamentals of Software Startups. Springer, Cham. https://doi.org/10.1007/978-3-030-35983-6_9 
Tripathi, N., Seppänen, P., Boominathan, G., Oivo, M., Liukkunen, K. (2019): Insights into startup ecosystems through exploration of multi-vocal literature. Information and Software Technology, 105, 56-77. doi:10.1016/j.infsof.2018.08.005.

Tucker, J., Chakma, J., Fedak, P. W. M., Cimini, M. (2011): Catalyzing capital for Canada's life sciences industry. Journal of Commercial Biotechnology, 17(4): 330-348. doi:10.1057/jcb.2011.26

Tyebjee, T. T., A. V. Bruno (1984): A Model of Venture Capitalist Investment Activity. Management Science, 30(9), 1051-1066. doi: 10.1287/mnsc.30.9.1051

Walter, Gy. (2014): Vállalatfinanszírozás a gyakorlatban - Lehetöségek és döntések a magyar piacon. Vállalatfinanszírozási lehetöségek. Alinea, Budapest.

Weiblen, T., Chesbrough, H. W. (2015): Engaging with startups to enhance corporate innovation. California management review, 57(2), 66-90. doi: 10.1525/cmr.2015.57.2.66

Wilson, N., Wright, M., Kacer, M. (2018): The equity gap and knowledge-based firms. Journal of Corporate Finance, 50, 626-649.

Wonglimpiyarat, J. (2011): The dynamics of financial innovation system. The Journal of High Technology Management Research, 22(1), 36-46. doi:10.1016/j.hitech.2011.03.003

Wonglimpiyarat, J. (2016): Government policies towards Israel's high-tech powerhouse. Technovation, 52: 18-27. doi:10.1016/j.technovation.2016.02.001

Wood, M. S., Long, A., Artz, K. (2020): Angel investor network pitch meetings: The pull and push of peer opinion. Business Horizons, 63(4), 507-518.

Wray, F. (2015): Venture capital and investor readiness in a post-crisis and staterescaling context: Revisiting the North East of England. Local Economy, 30(4), 389-404. doi:10.1177/0269094215582391

Zacharakis, A. L., D. A. Shepherd (2005): A non-additive decision-aid for venture capitalists' investment decisions. European Journal of Operational Research, 162(3), 673-689. doi:10.1016/j.ejor.2003.10.028

Zacharakis, A. L., G. D. Meyer (1995): The venture capitalist decision: understanding process versus outcome. In: Frontiers of Entrepreneurship Research 1995, szerk: W. D. Bygrave, B. J. Bird, S. Birley, N. C. Churchill, M. Hay, R. H. Keeley, W. E. Wetzel Jr, 465-478, Wellesley: Babson College.

Zacharakis, A. L., G. D. Meyer (1998): A lack of insight: do venture capitalists really understand their own decision process? Journal of Business Venturing, 13(1), 57-76. doi:10.1016/S0883-9026(97)00004-9

Zhang, L. (2014): Corporate Governance of Chinese State-controlled Listed Companies: A Revisit Through the Lens of Venture Capital. European Business Organization Law Review, 15(1), 107-139. doi:10.1017/S1566752914001050 